UNIVERSIDADE DE SÃO PAULO

FACULDADE DE FILOSOFIA, LETRAS E CIÊNCIAS HUMANAS DEPARTAMENTO DE HISTÓRIA

PROGRAMA DE PÓS-GRADUAÇÃO EM HISTÓRIA ECONÔMICA

ELVANDER DOS SANTOS PEDRO QUARESMA

ECONOMIA AÇUCAREIRA: SÃO TOMÉ E PRÍNCIPE (SÉCULO XVI AO XVII)

Versão corrigida

SÃO PAULO 


\section{ECONOMIA AÇUCAREIRA: SÃO TOMÉ E PRÍNCIPE (SÉCULO XVI AO XVII)}

\section{Versão corrigida}

Dissertação de Mestrado apresentada à Faculdade de Filosofia Letras e Ciências Humanas, da Universidade de São Paulo (FFLCH/SP), para obtenção do título de Mestre em História Econômica, sob a orientação da Profa. Dra. Vera Lucia Amaral Ferlini.

Orientadora: Profa Dra Vera Lucia Amaral Ferlini.

SÃO PAULO 
Autorizo a reprodução e divulgação total ou parcial deste trabalho, por qualquer meio convencional ou eletrônico, para fins de estudo e pesquisa, desde que citada a fonte.

Catalogação na Publicação

Serviço de Biblioteca e Documentação

Faculdade de Filosofia, Letras e Ciências Humanas da Universidade de São Paulo

Q1

Quaresma, Elvander dos Santos Pedro

/Elvander dos Santos Pedro Quaresma;

Orientadora/Vera Lucia Amaral Ferlini. - São Paulo, 2016.

$167 \mathrm{f}$.

Dissertação (Mestrado) - Faculdade de Filosofia,

Letras e Ciências Humanas da Universidade de São

Paulo. Departamento de História. Área de concentração:

História Econômica.

1. Açúcar. 2. Colonização. 3. São Tomé. I. Ferlini, Vera Lucia Amaral, orient. II. Título. 
QUARESMA, E. S. P. Econômica Açucareira: São Tomé e Príncipe (século XVI ao XVII). Dissertação apresentada a Faculdade de Filosofia, Letras e Ciências Humanas, da Universidade de São Paulo para obtenção de título de Mestre em História Econômica.

\section{Aprovado em:}

Banca Examinadora:

Prof.(a). Dr.(a). Instituição

Julgamento. . Assinatura.

Prof.(a). Dr.(a). Instituição

Julgamento. Assinatura.

Prof.(a). Dr.(a). Instituição

Julgamento. Assinatura. 
Aos meus pais, que um dia tiveram o sonho de me ter. O sonho realizado! Nasci e estou aqui. Desenhando, escrevendo e sonhando. Tudo por conta de um dia, os meus Avôs, terem tido também o sonho de terem os meus pais, este sonho que irá além, pois será repassado para meus filhos, que um dia terão que contar a mesma história. 


\section{Agradecimentos}

Antes de mais, quero agradecer a Profa. Dra. Vera Lucia Amaral Ferlini, por ter me aceite como seu orientando nesta dissertação e em partilhar a sua experiência como historiadora e professora, uma experiência que estava muito longe do meu alcance, pelo fato de não ser um historiador, e de ter vindo de áreas bem diferente: "Administrativo e Econômico". A troca de experiência essa que veio incentivar em grande medida toda a dinâmica no processo da minha formação, possibilitando um entendimento melhor dos conteúdos históricos em todas as etapas desse trabalho, bem como o enriquecimento do mesmo.

Ao professor Dr. Rodrigo Ricupero, por ter-me co-orientando inicialmente e sempre me ter apoiado no que eu precisava, dentro da possibilidade e norma acadêmica. Lembro que um dia, nos encontramos por acaso no ônibus, e precisava resolver um assunto urgente, relacionado à assinatura para uma documentação, que poderia ser assinado por um professor, conversei na hora e a disposição do professor foi imediata, no mesmo instante que havia solicitado: Achei o gesto muito nobre e disso jamais esquecerei.

À Professora Dra. Tathianni que desde começo do curso de mestrado, quem me deu muitas dicas e quando membro da banca de qualificação situou a minha pesquisa no caminho mais ajustado, indicando várias formas concretas no campo histórico, assim ampliando a minha confiança e estreitando as minhas incertezas quanto ao desenvolvimento do trabalho, e renovando cada vez mais, em cada reunião convocado pela orientadora, na qual também se encontrava.

Ao Professor Dr. Pablo, que no primeiro contato, ao participar na banca da minha qualificação, formulou muitos bons comentários e algumas duras críticas "construtivas" reforçando assim o enriquecimento e aprimorarão deste trabalho, que sem dúvidas foi uma grande recompensa.

Ao Professor Dr. Pedro Puntoni, na sua disciplina: Economia e Capitalismo no Antigo Regime. A disciplina visava discutir algumas das questões sobre a natureza do poder e das instituições no espaço do Império Português do Antigo Regime. O curso buscava analisar a formação do império português no decorrer de cinco séculos por 
meio de instituições que lhe conferiam sentido e permitiram o seu funcionamento ao longo deste período. A aula expositiva procurou estimular a reflexão sobre problemas históricos e reflexões historiográficas. O curso teve grande contributo para o meu trabalho, pois as técnicas usadas ao longo do curso e as bibliografias contidas enriqueceram e trouxeram um melhor direcionamento para trabalho. Baseado na aula expositiva e no seminário desenvolvido pelos próprios alunos trouxe uma maior critica e reflexão sobre o mundo colonial português.

Quero confessar que cheguei neste curso muito cru, em relação a questões envolvendo história, pelo motivo já mencionado, mas acredito que as orientações e sugestões obtidas ao longo do curso trouxeram uma grande maturidade, embora sabendo que os meus conhecimentos da área encontram ainda limitados, frente à diversidade desta área. Não obstante a tudo isso, devido o gosto que comecei a ganhar pelo curso da historia econômica, espero e me esforçarei para, que pelo menos, o resultado tenha chegado próximo das orientações e sugestões dadas.

Ao Dr. Prof. Ricardo Daniel Moyano (Universidad Nacional de Tucumán) e Prof. Alexandre Saes (Universidade de São Paulo), na disciplina "História de Empresas: Enfoques Teóricos e Estudo de Casos", ministrada pelos mesmos. O que chamou a minha atenção na disciplina seria o trabalho do professor Dr. Mayano, que retratava da historia de uma empresa açucareira em Argentina do ano 1907 a 1949: Moyano, Daniel. "Empresa y familia en la agroindustria azucarera tucumana: el caso de la firma “Avellaneda \& Terán” (1907-1949)”. História Econômica\& História de Empresas. Vol. 14, $\mathrm{N}^{\circ}$ 1, 2011. Embora a produção açucareira em causa fosse de uma época bem diferente ao que se refere no meu trabalho (Sec. XVI ao XVII), isso foi uma forma de refletir e comparar a evolução e a dinâmica do açúcar em diferentes países e em diferentes épocas. Além de o trabalho final entregue ser uma confrontação da economia açucareira em São Tomé no século XVI ao XVII versus empresa açucareira em Argentina do ano 1907 a 1949, que veio a trazer muitos contributos para aprimorarão deste trabalho.

Nesta faculdade, estabeleci contato com um conjunto de colegas e professores, que sem duvidas, marcaram muito a minha formação intelectual, graças ao convívio e a conversas constantes as quais sempre mostravam as suas desposiçoes. A Sra. Patrícia Machado, secretaria da professora Vera, "da Cátedra Jaime Cortesão" que sempre teve boas recepções aos orientandos da professora, paciente e muito carinhosa nas suas falas, pronta para ajudar no que vier, seja via telefônico ou presencial, nos momentos difíceis 
e não. Isso que alguma forma contribuiu para engrandecimento do trabalho. Ao Nelson da secretária de História Economia e Social, sempre pronto em atender as necessidades dos alunos, muitas vezes, em momentos de muita angustia "numa época que estava sem bolsa" soube gentilmente conversar e buscar soluções viáveis dentro da própria universidade, pelo fato de conhecer bem a universidade. Ao Professor Pablo, "por ter participado da banca e ainda orientando da professora Vera do Pós - Doutorado" que sempre que tenho oportunidade, tivemos boas conversas sobre a evolução, repassando assim sua experiência como pesquisador e com trabalhos já desenvolvidos. A Professora Thatiane que praticamente, em todos os lugares que nos encontramos pergunta do trabalho, sempre reforçando nas dicas e reconvenções dos livros. Aos colegas Tomé Maloa, Pedro Christian Lüders, Gilvan Leite de Oliveira; "Ana Carolina Ammon; André Filippe, etc., todos do curso de História Econômica, que sempre que nos encontramos conversamos e trocamos as nossas experiências do trabalho e isso de alguma forma trouxe um diferencial para o trabalho.

Aos colegas do apartamento e do dia a dia: Ailtom Gineni de Almeida, colega do Instituto de Psicologia da Universidade de São Paulo; José Manuel Lopes, colega da Faculdade de Geociências da Universidade de São Paulo; Tâmara Águas, colega de Escola de Comunicações e Arte - Relações Públicas da Universidade de São Paulo; Isabel Sousa, colega a Faculdade de Saúde Pública da Universidade de São Paulo Nutrição; Silviane Alice Lima: colega a Faculdade de Saúde Pública da Universidade de São Paulo - Nutrição; Issiaka Throare, colega da Faculdade de Economia, Administração e Contabilidade da Universidade de São Paulo; Janise Gomes, colega de Faculdade de Odontologia da Universidade de São Paulo e entre outros, que com os nossos convívio veio fortalecer a certeza de que existe em nossos objetivos aqui nesta universidade, traçando as metas a serem cumpridas, separando cada coisa na sua hora, definindo sempre o que seriam as prioridades. Esses momentos quando lembrados, deixa muitas saudades, casa onde morávamos em Vila Indiana, das atividades que realizávamos, nos momentos livres (jogos e brincadeiras), que de alguma forma nos deixavam muito fortes. Uma vez no meu aniversário, já eram quase vintes três horas (23:00h), boas parte dos estabelecimentos comerciais em torno da moradia estava fechado, quando saiamos para comprar algo para comemorar. Foi um dia inesquecível, pois fomos de ônibus porque no bairro, estava tudo fechado, e na volta, viemos a pé, quase quatro horas depois, ou seja, três da madrugada do dia seguinte, para comemorarmos o meu aniversário. Nas festas do final do ano, maioria das vezes, 
comemorados entre os colegas, pelo fato de não conseguir a passagem de regresso do final do ano, fazíamos uma contribuição e nos organizamos para fazer festa (pratos típicos, musicas e danças, etc.,). Cada um assumia uma responsabilidade em uma determinada tarefa. As festas sempre eram um sucesso, sendo que seria uma oportunidade de mostrar os pratos de cada país, as danças, os ritmos aos amigos e convidados, que antes disso, nunca havia conhecido de perto. Isto trouxe, de forma direta ou indireta, um aprendizado muito grande, na medica que nesses encontros, cada um acabava se expondo suas experiências acadêmicas, de vida, de luta e de sobrevivência.

Ao longo dessa dissertação apreendi que o conhecimento ou aprendizado é como uma maquina produtiva (uma maquina qualquer - seja ela para produzir tecidos ou um equipamento de pesca), é necessário haver incentivo de algum dos lados (da parte que consome o produto e da parte que os produzem), para que possamos aprimorar e melhorar a nossa produção. Nesse aprendizado, mais incentivos (críticas e sugestões e a necessidade envolvida), mais aprimoramos a nossa produção e isso é fundamental em qualquer tipo de atividade.

À professora Dra.Vera Ferlini, quero uma vez mais, reforçar, assim atribuir o maior contributo no desenvolvimento desse trabalho, sendo que quando cheguei nesta faculdade, não a conhecia pessoalmente, mas logo em primeiro contato estabelecido, ainda no primeiro dia que havia marcado com a sua secretaria "Patrícia Machado" fui muito bem recebido, e me passou todas as orientações inicias do trabalho. Também suas sugestões e criticas sobre a escrita no sentido profundo seria de grande relevância e a isso, quero dar a Senhora um agradecimento especial. Lembro que quando muito precisei da professora, no momento que precisava faz um estudo nos arquivos históricos de Lisboa, nomeadamente: “Arquivo Histórico Ultramarino, Arquivo Nacional de Torre de Tombo (ANTT), e Centro de Estudo de História do Atlântico (CEHA), Arquivos esses muito citados nas literaturas relacionados ao trabalho, ou seja, relacionado produção açucareira no Atlântico" obtive todo o apoio, desde a seleção dos documentos a serem pesquisados, viagens, estadias, etc., como não se lembrar de um momento desses.

Ao Professor Alberto Vieira, investigador-coordenador (correspondente ao professor catedrático), do Centro de Estudos da História do Atlântico, situado na Rua das Marquês, no Funchal, Ilha da Madeira, Portugal, por ter aceito supervisionar durante o intercambio de estágio nesta em Portugal, no período de Dezembro de 2015 a 
Março 2016, com finalidade de pesquisar e aprimorar o meu trabalho de dissertação. Na qual me apoiou e apóia até hoje com recomendações de fontes, livros e artigos.

$\mathrm{O}$ apoio institucional foi e é muito valioso porque em muitos momentos quando precisei deles, foram muitos úteis. A Cátedra Jaime Cortesão da Universidade de São Paulo, onde sempre que possível encontra-se colegas e professor que proporcionam grandes discussões que, tem sempre um impacto positivo no desenvolvimento do trabalho. Também a CAPES, cuja bolsa permitiu que me dedicasse integralmente à pesquisa, enquanto o obtive. Nesta, ajudou muito, pois, de inicio não tive uma bolsa e as coisas pareciam bem mais difíceis, pois precisei trabalhar por um período, nesta acabava atrapalhando no desenvolvimento da dissertação, mas a partir do momento que obtive bolsa, no segundo semestre de 2015, ajudou e muito, inclusive contribuiu para fins de pesquisas que precisei fazer em Portugal.

Agora seria agradecer a família. Posso considerar dentro da minha família a primeira geração que ingressou em um curso superior e isso me faz sentir muito orgulhoso. Eu sou segundo filho dos meus Pais. O primeiro filho, Dadubill Pedro Quaresma se engrenou por trabalhar cedo, na época não entendia muito bem qual seria o motivo, talvez por ser mais velho, precisava ajudar em casa, ou talvez porque não tivesse muito gosto por estudos. O terceiro, Jeromildo dos Santos Pedro Quaresma, não queria saber de estudar, embora tivesse todo apoio dos meus país, preferiu ser comerciante. O ultimo irmão, os outros, começaram a fazer faculdade recentemente, $\mathrm{E}$ os meus primos, boa parte deles estão terminando ensino médio e se interessando por faculdade agora. Antes da nossa geração, não houve nenhum histórico de família que houvesse feio uma Faculdade. Enfim, dizendo que a razão e motivo de tudo isso, seria a minha mãe, Maria do Rosário Soares Pires dos Santos, Mulher que me deu vida e me acompanhou em vários momentos difíceis da minha vida. Lembro-me que uma vez a minha mãe viajou para um país vizinho em negócios, soube que fiquei doente, retornou no dia seguinte para cuidar de mim. Disso, fico eternamente grato e não tem palavras para retratar o amor dessa mulher pelos seus filhos, um amor que neste espaço não havia folhas que pudessem caber, se tivermos que descrever. 
QUARESMA, E. S. P. Econômica Açucareira: São Tomé e Príncipe (século XVI ao XVII). Dissertação (Mestrado) Faculdade de Filosofia, Letras e Ciências Humanas, da Universidade de São Paulo, 2017.

Resumo:

Os portugueses na sua expansão marítima encontraram nas ilhas do Atlântico uma forma para a implantação de um sistema de colonização fundamentada na exploração comercial de bens primários, dentre eles destacou-se o açúcar. A cana-deaçúcar mostrou-se ser um comércio muito viável nessas ilhas, principalmente em São Tomé, gerando desta forma uma importante fonte de renda para os portugueses. Mão de obra baseada no trabalho escravo, condições favoráveis do clima, técnica de produção, o preço e a demanda deste produto no mercado internacional, assim como a boa fertilidade da terra em S. Tomé, foram os principais alicerces no sucesso do negócio. Rapidamente, em São Tomé, surgiu mais de sessenta engenhos produtores de açúcar, cuja produção era quase toda exportada para a Europa. Alem de açúcar, o país também produzia pimenta (com grande consumo interno) e a exportação de madeiras e posteriormente, cacau, café, óleo de palma, noz de coco e copra. Devido à sua localização, S. Tomé funcionava como entreposto comercial entre África, Europa e, mais tarde, o Brasil.

Palavra Chave: Açúcar, Colonização, São Tomé. 
QUARESMA, E. S. P. Sugar Economy: São Tome and Principe (Centure XVI XVII). Dissertação (Mestrado) Faculdade de Filosofia, Letras e Ciências Humanas, da Universidade de São Paulo, 2017.

\section{Abstract:}

The Portuguese in their maritime expansion found in the Atlantic islands a form for the establishment of a colonization system based on the commercial exploitation of primary goods, among them sugar. Sugarcane proved to be a very viable trade in these islands, especially in São Tomé, thus generating an important source of income for the Portuguese. Labor based on slave labor, favorable climate conditions, production technique, the price and demand of this product in the international market, as well as the good fertility of the land in S. Tomé, were the main foundations in the success of the business. In São Tomé, more than sixty sugar-producing sugar mills were quickly produced and exported to Europe. Besides sugar, the country also produced pepper (with large domestic consumption) and the export of wood and later, cocoa, coffee, palm oil, coconut and copra. Due to its location, S. Tomé functioned as a commercial warehouse between Africa, Europe and, later, Brazil.

Key words: Sugar, Colonization, São Tome. 
Lista de Figuras:

Figura 1 - Mapa de S. Tomé Feito Pelo Holandês Johannes Vingboons (1655).

Figura 2 - Escravos saindo de São Tomé com destino as Americas (1781).

Figura 3-Baia de Anna de Chaves, constando a cidade capital, a Fortaleza de Sebastião e o Forte do Pico da Nossa Senhora da Graça (1644).

Figura 4 - Plantas de Cana de Açúcar

Figura 5 - Alçaprema ou Lagar Almanjarra Primitiva da Madeira

Figura 6 - Engenho de Açúcar Siciliano da Segunda Metade do século XVI.

Figura 7- Moenda Primitiva a Forca Animal.

Figura 8 - Moenda de Três Cilindros Verticais Movida à Força Humana

Figura 9 - Moenda de três cilindros movido por força hidráulica

Figura 10 - Engenho de Três Cilindros Verticais a Tração Animal, com Suporte Humano.

Figura 11-Diferença no Rendimento em Diferentes Tipos de Moeda para o mesmo Volume da Cana-De-Açúcar 
Lista de Gráficos

Gráfico 1 - Produção Açucareira na Ilha da Madeira de 1470 - 1510.

Gráfico 2 - Produção Açucareira em Açores, de 1502 a 1509.

Gráfico 3 - Produção Açucareira na Ilha da Madeira de 1455 a 1537.

Gráfico 4 - Carregamento do Açucar de Navios Português para Antuérpia (1536-1550). 
Lista de Tabela

Tabela 1- Expansão do Açúcar, a partir do Ano 1000.

Tabela 2 - Navios Portugueses com Açúcar para Antuérpia (1536 - 1550).

Tabela 3 - Aproveitamento da Garapa em Função do Número do Cilindro da Moenda 
SUMÁRIO

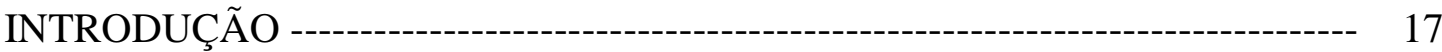

\section{CAPITULO I}

1 - DO DESCOBRIMETO À IMPLANTAÇAO DA PRODUÇÃO ------------- 27

1.1 - Descobertas das ilhas de São Tomé e Príncipe -------------------------- 28

1.2 - Fatores que levaram a descoberta -------------------------------------------- 36

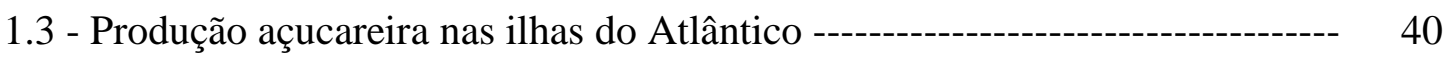

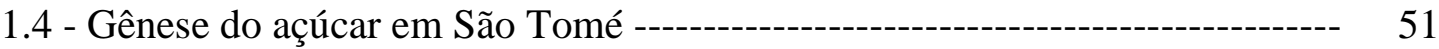

1.5 - Mão de obra na produção açucareira --------------------------------------- 56

1.6 - Comércio do açúcar no mundo Atlântico ------------------------------------- 64

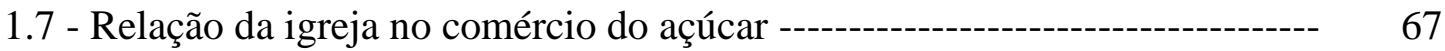

1.8 - A decadência do açúcar ------------------------------------------------------ 71

\section{CAPITULO II}

2 - FATORES PERTINENTES PARA O ÊXITO DA ECONOMIA 79 AÇUCAREIRA EM SÃO TOMÉ E PRÍNCIPE

2.1 - Localização privilegiada 79

2.2 - Abundância de mão de obra 84

2.3 - O valor o a procura do açúcar no mercado internacional 86

\section{CAPITULO III}

3- RELAÇÃO DO PROCESSO PRODUTIVO EM SÃO TOME COM 
3.1 - A cana-de-açúcar

3.2 - Nível produtivo 99

3.3 - Desenvolvimento técnico 110 CONSIDERAÇÕES FINAIS 127 FONTES 132 REFERENCIAS 164 


\section{INTRODUÇÃO}

O fabrico e consequentemente o comércio do açúcar, desde muito cedo fez parte da história de São Tomé e Príncipe. Aspectos estruturais, geográficos e históricos, foram de fundamental importância para o estudo da história do açúcar nessas ilhas. Após sua descoberta, o país vem se mantendo política e economicamente, graças à agricultura. Sua localização privilegiada, clima propício ao cultivo da cana-de-açúcar e fertilidade da terra, tornou possível a fixação portuguesa. O país vivenciou vários ciclos econômicos baseado na agricultura: ciclo do açúcar, do café e do cacau, que assegurou a dinâmica da economia dos portugueses, enquanto nessas ilhas permaneceram.

O açúcar foi a primeira grande riqueza agrícola e industrial do São Tomé e Príncipe introduzida anos após a sua descoberta. As ilhas de São Tomé e Príncipe fazem parte de um conjunto vulcânico, que além daquelas, também fazem parte as ilhas de Ano Bom e Fernando Pó, que se alinham segundo bissetriz do Golfo da Guiné, na costa ocidental da África, e que se prolongam pelo continente. Este conjunto apresentou-se aos olhos dos seus descobridores como muito original: uma originalidade de relevo, clima e vegetação, em virtude da situação equatorial das ilhas, nova para quem conhecia somente arquipélagos subtropicais das Atlânticas ${ }^{1}$.

O País localiza-se no Golfo da Guiné, sendo os países mais próximos ${ }^{2}$ ao norte a Nigéria, a este o Gabão e a nordeste Camarões e a Guiné Equatorial. Até que as ilhas ganhassem a sua independência em 1975, elas foram uma província ultramarina de Portugal. As ilhas foram descobertas ${ }^{3}$ por Pêro Escobar e João de Santarém, navegadores portugueses ao serviço do Rei Dom Afonso V de Portugal que exploravam a costa ocidental africana na época. A ilha de São Tomé foi descoberta em 21 de dezembro de 1470, enquanto a ilha de Santo António foi descoberta a 17 de janeiro de

\footnotetext{
${ }^{1}$ Dada a orientação do alinhamento vulcânico, estão progressivamente mais afastadas da costa africana a partir da porção mais setentrional: enquanto Fernando Pó se distancia em 20 milhas do litoral, a Ilha do Príncipe está cerca de 160 milhas, São Tomé a 180 milhas e a ilha Ano Bom, a mais afastada, a 200 milhas. São Tomé e Príncipe distam-se entre si em 82 milhas. Ver: TENREIRO, Francisco. A Ilha de São Tomé. Lisboa: Junta de Investigações do Ultramar, 1961. p. 13.

${ }^{2}$ Nigéria está a $200 \mathrm{~km}$, Gabão aproximadamente a $300 \mathrm{~km}$, enquanto Guiné Equatorial e Camarões estão a $250 \mathrm{~km}$. Ver: INSTITUTO NACIONAL DE ESTATÍSTICA. Características e condições de vida das famílias e da habitação, RGPH-2012. São Tomé: INE, 2012. p. 26.

${ }^{3}$ Os historiadores e muitas lendas santomenses advertem que as ilhas de São Tomé e Príncipe já eram habitadas quando lá chegaram os portugueses. Para eles, uma população nativa provavelmente descendente dos sobreviventes de um navio que ali naufragou muito antes da data do descobrimento pelos portugueses. Essa pequena povoação habitou durante muito tempo na costa sudeste da ilha, e foram eles, certamente, quem fizeram algumas revoltas, no momento de grande exploração agrícola, principalmente a do açúcar. Ver: LAINS E SILVA, Hélder. São Tomé e Príncipe e a cultura do café. Lisboa: Junta de Investigações de Ultramar, 1958. p. 42.
} 
1471, e passou depois a se chamar da ilha do Príncipe em homenagem a Dom João II. Descobertas e reivindicadas por Portugal no final do século XV, a economia das ilhas era baseada no açúcar que deu lugar posteriormente ao café e ao cacau no século XIX, todos cultivados com o trabalho escravo, exploração que persistiu até o século XX.

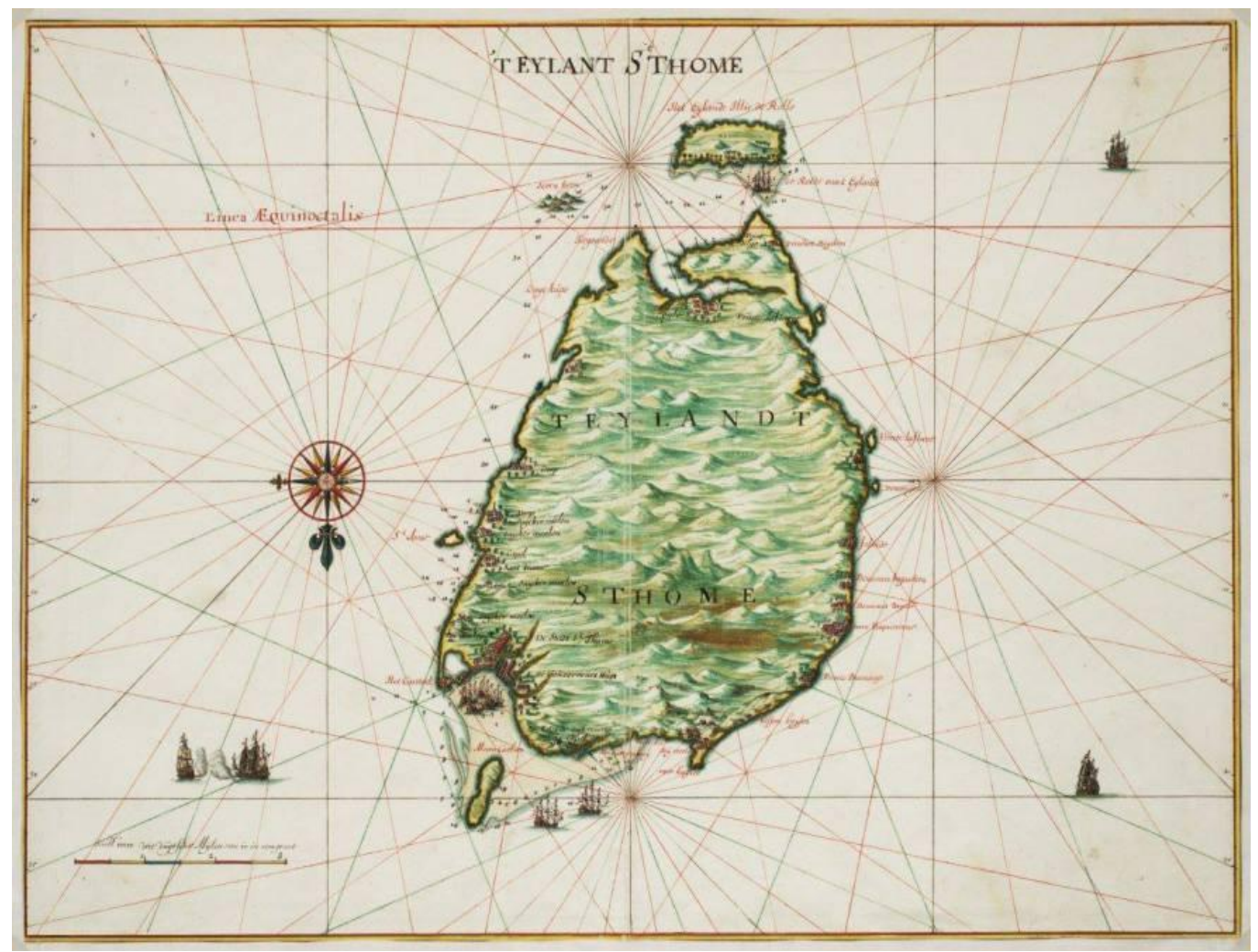

Figura 1: Mapa de S. Tomé feito pelo Holandês Johannes Vingboons (1655) Fonte: Instituto Universitário de Lisboa: Centro de Estudos Internacionais - CEI

A cultura da cana-de-açúcar teve uma longa trajetória, até que chegasse à região do Atlântico. No que se sabe, e o que parece ser mais provável, é que a sua origem é Oriental, como pode ser observado em algumas literaturas. Segundo Godinho ${ }^{4}$, na China, a planta já era conhecida no século II antes de Cristo, e no Ocidente, as primeiras menções aparecem nos textos gregos e latinos tardiamente. O açúcar, oficialmente é cultivado no Oriente provavelmente no século IV, são os mulçumanos que o levarão para todo o Atlântico. Outro grande centro de cultivo e indústria do açúcar foi o Egito, que desde o século X produzia o produto. Logo em seguida temos a Síria, as Ilhas de Chipre e de Creta. Nessas regiões se vendia açúcar em bruto ou refinado, quer em pó ou em pães alvíssimos ${ }^{5}$, sendo a melhor qualidade o cândi ${ }^{6}$ com principal mercado no

\footnotetext{
4 GODINHO, Vitorino Magalhães. Os descobrimentos e a economia mundial. Lisboa: Editorial Presença, 1963. v. 4. p. 70.

${ }^{5}$ Fiz uma busca do significado do termo (pães alvíssimo) em alguns livros relacionados ao assunto e na web e não encontrei. Porém, tentei procurar as palavras separadamente em vários dicionários da língua
} 
Cairo. Para Francisco Tenreiro a cana-de-açúcar também veio do Oriente, trazida pelos Árabes para o Mediterrâneo. Sendo que no fim do século XV a Sicília era seu principal produtor. A cana-de-açúcar foi trazida para Portugal pelo infante D. Henrique, que a cultivou em algumas regiões, como: Algarves, Campo Mondego e Ilha da Madeira. Daqui, irradiando mais tarde para as outras Ilhas do Atlântico, tais como: Cabo Verde, São Tomé e Príncipe e mais tarde para o Brasil ${ }^{7}$.

Navegadores portugueses desembarcados em São Tomé, buscaram uma área de fixação diferente da primeira utilizada por estes, uma enseada a Noroeste, onde foi fundada a primeira povoação, está seria transferida para o Nordeste, onde havia mais superfície de terra baixa e maior facilidade de penetração para o interior. Foram experimentadas culturas alimentares e arvores de frutas, mas foi à cana-de-açúcar, a cultura de rendimentos econômicos com êxito, dependente essencialmente das condições climáticas e abundância de mão de obra $^{8}$, necessariamente vindo do continente africano, a que teve mais sucesso.

Durante quase três séculos, a prosperidade da ilha se assentou quase exclusivamente a produção da cana-de-açúcar e outras culturas que se propagavam na sombra da primeira. Para esta plantação derrubou-se grande parte das florestas que a

portuguesa (Aurélio, Priberam, etc..), e todos os consultados sugerem um mesmo significado. Alvíssimo é um objeto branco, puro e ou limpo, o que leva a crer que pães alvíssimo se refere a forma que retira o açúcar mais branco. Ver: FERREIRA, Aurélio Buarque de Holanda. Novo Aurélio Século XXI: o dicionário da língua portuguesa. $3^{a}$ edição. Rio de Janeiro: Nova Fronteira, 1999.

${ }^{6}$ Açúcar candi, definido como açúcar macho ou superior, branquíssimo e duro, semelhante ao cristal, por oposição ao açúcar fêmea, menos puro, mais brando e doce, distinguindo este açúcar branco do mascavado, tipo de açúcar inferior ao anterior. Em Valência, o açúcar candi é elaborado desde princípios do século $\mathrm{XV}$, não apresentando a forma de pão, mas de cristais, existindo duas qualidades: sucre candi domesquí e sucre candi alexandrí. O açúcar candi é refinado e, por isso, não exige formas para a sua elaboração, cristalizando, lentamente, em porrones para permitir a formação de grandes cristais. Ver: NUNES, Naidea Nunes. O açúcar de cana na ilha da Madeira: do Mediterrâneo ao Atlântico Terminologia e tecnologia históricas e actuais da cultura açucareira. 2002. 778 f. Tese (Doutorado em Linguística Românica) - Faculdade de Artes e Humanidades, Universidade da Madeira, Funchal, 2002. p. 135.

${ }^{7}$ TENREIRO, Francisco. A Ilha de São Tomé. Lisboa: Junta de Investigações do Ultramar, 1961. p. 67.

${ }^{8}$ A ilha de São Tomé, após a sua descoberta, foi usada como depósito de escravos vindo de quase toda África e depois serem exportados para diferentes países da Europa e América. "But the most spectacular and successful use of negro slave labour was offered by the islands of São Tomé and Príncipe in the golf of Guinea. Uninhabited when first discovered Portuguese about 1470, they were colonized by mixture of the White settlers send from Portugal (including levies Jewish children deported in 1490s) and by the labour force of negro slaves secured from a wide variety of tribes on the mainland, many of whom subsequently gained their freedom". Ver: BOXER, Charles Ralph. The portuguese seaborne empire: 1415-1825. Michigan: Penguin, 1973. p. 90. 
cobriam, sendo a terra retalhada em grandes propriedades. Nela passaram a habitar, além de numerosos serviçais, portugueses qualificados do continente e dos outros arquipélagos atlânticos e alguns estrangeiros, entre eles os genoveses, o que permitiu a criação de uma sociedade crioula que perdura até os nossos dias. O solo e o clima de São Tomé mostraram-se muito favoráveis ao cultivo de cana-de-açúcar e a ilha experimentou um notável progresso econômico durante a maior parte do século XVI, com o rápido aumento da procura europeia pelo açúcar.

No século XII, o cultivo da cana-de-açúcar era bastante restrito, se encontrava somente nas regiões da Grécia, Sul de Itália e no Sul de França, nas quais a sua produção era muito reduzida, sendo os orientais maiores fornecedores deste produto para o mundo ocidental. O açúcar permanecia como um produto gastronômico, medicinal e de luxo, vendido nos boticários ${ }^{9}$, ao alcance de poucos. Durante séculos, o açúcar foi considerado uma especiaria extremamente rara e valiosa. Apenas em lugares como palácios reais e em casas de nobres era possível consumir açúcar, visto que seus preços eram altíssimos, podendo ser apenas acessível às classes abastadas. O valor e a importância do açúcar, pelo seu preço e seu uso, contava entre as especiarias e produto de luxo na Idade Média, como pode ser destacado por Godinho: o açúcar usava-se para adoçar bebidas e alimentos e estavam restritos às mesas dos grandes e poderosos senhores, quando apreciada, era por um ou outro capitalista. Utilizavam-no como mezinha, no tratamento dos olhos ou da garganta, e até outras regiões que se pretendia cicatrizar $^{10}$. A indústria açucareira de São Tomé estava ainda florescente em 1530 e a produção aumentou de cerca de 5.000 arrobas neste período para 150.000 , em 1550. A

\footnotetext{
${ }^{9}$ São a farmácias, entre século XIV a XVII aproximadamente, que vendiam produtos medicinais valiosos. Os boticários eram também vendedores de fórmulas preparadas por eles mesmos, mas elaboradas pelos saberes dos médicos que as prescreviam, cujos conhecimentos distinguiam-se em importância daqueles dos boticários, "cozinheiros dos médicos". Ver: MARQUES, Vera Regina Beltrão. Boticários: a preparação de um ofício mecânico em domínios portugueses no setecentos. In: FÓRUM SUL DE COORDENADORES DE PÓS-GRADUAÇÃO EM EDUCAÇÃO. II Seminário de Pesquisa em $\begin{array}{llll}\text { Educação } & \text { da } & \text { Região } & \text { Sul, }\end{array}$ Curitiba. Disponível em:<http://www.portalanpedsul.com.br/admin/uploads/1999/Historia_Da_Educacao/ Trabalho/05_37_31_BOTICARIOS_A_PREPARACAO_DE_UM_OFICIO_MECANICO_EM_DOMI NIOS_PORTUGUESES_NO_SETECENTOS.pdf $>$. Acesso em: 11 jan. 2017. p. 3.

${ }^{10}$ GODINHO, Vitorino Magalhães. Os descobrimentos e a economia mundial. Lisboa: Editorial Presença, 1963. v. 4. p. 69.
} 
transplantação do cultivo do açúcar e da escravatura negra para o Brasil, que começou por esta altura, foi uma consequência natural do exemplo fornecido por São Tomé ${ }^{11}$.

Uma questão importante, que será analisada e discutida ao longo do trabalho, está relacionada ao momento que inicia a produção açucareira em São Tomé. Segundo Boxer $^{12}$, a produção seria florescente em 1530 e para outros autores, como Celso Furtado, Godinho, Francisco Tenreiro, etc., a produção já havia começado no final do século XV. Outro aspecto importante estaria relacionado à crise da cana-de-açúcar em São Tomé e Príncipe, em nota observada por Furtado o açúcar na Ilha da Madeira e em São Tomé já havia alcançado uma produção em alta escala na segunda metade do século $\mathrm{XV}$, época em que os venezianos ainda conservavam intactas as suas fontes de abastecimento das ilhas do Mediterrâneo Oriental ${ }^{13}$. Pode-se perceber nas palavras de Boxer, que a transplantação da cana-de-açúcar seria uma consequência natural do processo. Talvez tenha contribuído para isso a instabilidade social do final do século XVI quando a ilha viveu um período de revoltas dos angolanos ${ }^{14}$, a quem se juntavam os escravos que trabalhavam nos engenhos do açúcar; além de ataques de corsários originários de outras potências europeias, nomeadamente a França e a Holanda, e a luta pelo poder entre os próprios colonos. Até o século XIX assiste-se ao declínio da produção de açúcar em São Tomé devido ao grande fluxo migratório de colonos portugueses para o Brasil, que oferecia melhores condições, e ao abandono das culturas por parte dos forros, que se dedicavam a uma agricultura de subsistência.

A cana sacarina inserida pelos portugueses em São Tomé e Príncipe tornou-se o principal produto das ilhas que contou com as técnicas trazidas das experiências anteriores com o produto pelos colonizadores. No início, as terras descobertas se mostraram inviáveis ao cultivo. O cereal durante o século XIV foi um produto muito procurado em toda a Europa e principalmente em Portugal, aonde boa parte das terras

\footnotetext{
11 The soil and climate of São Tomé proved to be very favorable for the cultivation of sugar, and the island experimented a remarkable economic boom for most of the sixteenth century with the rapid increase in the European demand for sugar. The São Tomé sugar industry was a flourishing on by 1530, and production increase from some 5,000 arrobas in that year to over 150,000 arrobas in 1550. Ver: BOXER, Charles Ralph. The portuguese seaborne empire: 1415-1825. Michigan: Penguin, 1973.

${ }^{12}$ BOXER, Charles Ralph. The portuguese seaborne empire: 1415-1825. Michigan: Penguin, 1973.

${ }^{13}$ FURTADO, Celso. Formação Econômica do Brasil. 32a ed. São Paulo: Companhia Editora Nacional, 2005. p. 26.

${ }^{14}$ População que habitava na zona sul da ilha de S. Tomé, composta por escravos sobreviventes do naufrágio de um navio negreiro ou nativos, a depender do autor. Ver: A.H.U. S.Tomé, cx. 59, doc. 57 Relações da viagem de Lisboa às ilhas de Ano Bom, S. Tomé (1770).
} 
não apresentava condições adequadas para o seu plantio. Mais de um terço dessas terras era rochoso e pedregoso, as poucas terras restantes não eram suficientes, para uma produção capaz de satisfazer as demandas do mercado. Diante desta dificuldade, surgiram rapidamente mais de 60 engenhos produtores de açúcar nas ilhas, sendo a produção exportada para a Europa. O açúcar ao se desenvolver em São Tomé trouxe consigo outras culturas, tais como: a produção de pimenta (pimenta alimentício ou malagueta - para acompanhar as refeições), criação de gado, e indústria da madeira que servia para construções mobiliarias e navais. Devido à sua localização, São Tomé funcionava como entreposto comercial entre a África, a Europa e, mais tarde, o Brasil. A população era constituída por várias camadas sociais, que são: os grandes senhores portugueses, o clero, outros colonos portugueses, os escravos ${ }^{15}$ e os forros (escravos dos primeiros colonos e os seus descendentes, assim chamados por lhes ter sido concedida a libertação, por D. Manuel I, através de uma carta de alforria) ${ }^{16}$.

Arlindo Caldeira ${ }^{17}$ mostra-nos como era a dinâmica da economia sacarina em São Tomé, na qual retrata o seguinte: "vemos muitos navios de Vila Conde ${ }^{18}$ no transporte de açúcar do arquipélago, partindo ou regressando a Lisboa, e, a partir daqui, demandando Antuérpia ou o Levante”. Para o mesmo autor, em um recenseamento de embarcações realizado em 1552, embora com totais claramente subavaliados, contabilizava-se 42 navios, fundeados ou em viagem, registrados em Vila de Conde. Destes, cerca de 10 navios (25\% do total dos navios) estavam em São Tomé ou dirigiam para lá e cinco navios (cerca de 12\%) andavam em atividade no Levante. No século XVI, por volta de 1536 , a produção de açúcar em São Tomé assume o controle no principal mercado internacional consumidor deste produto. Antes dessa época, mais precisamente no centuário de quatrocentos, a ilha da Madeira surgira como o único mercado de produção, e a partir de finais desse século, entra em cena a concorrência do açúcar de São Tomé, posteriormente do Brasil e das Antilhas. Para se ter uma ideia, entre os anos 1536 e 1550, o número de navios que saiam para o principal

\footnotetext{
15 Os escravos representavam grande quantidade da massa trabalhadora para produção, nos quais a maioria deles importados do continente africano. Ver: A.H.U., S.Tomé, cx. 59, doc. 57 Relações da viagem a Lisboa às ilhas de Ano Bom, S. Tomé (1770).

${ }^{16}$ A.H.U., S.Tomé, cx. 59, doc. 57 Relações da viagem a Lisboa e às ilhas de Ano Bom, S. Tomé (1770).

${ }^{17}$ CALDEIRA, Arlindo Manuel. Viagens de um piloto português do século XVI à costa de África e a São Tomé. $1^{a}$ ed. Lisboa: Gráfica Maiadouro, S.A., 2000. p. 26.

${ }^{18}$ Vila de Conde, em meados do século XVI, era um dos mais importantes centros comerciais do norte de Portugal. Ela pertencia a corda de portos que ía da foz do Douro até Caminha, que concentrava (exceto Lisboa) a maior fatia do comércio do Atlântico português.
} 
mercado consumidor, proveniente dos diversos fornecedores de açúcar, tais como: Ilha da Madeira, Canárias, São Tomé e Cabo Verde totalizavam de 119 navios carregados de açúcar, 88 eram provenientes de São Tomé ${ }^{19}$.

O comércio de escravos teve também uma grande contribuição e participação na produção açucareira em São Tomé e que sem esta, a produção não teria conhecido grandes prosperidades. Boxer ${ }^{20}$ aponta que desde as primeiras viagens de descobrimento e comércio, ao longo da costa da Guiné, escravos, ouro e marfim eram os bens primários mais procurados pelos portugueses. Primeiro a ilha de Santiago de Cabo Verde e depois São Tomé, tornam-se depósitos de escravos, onde os escravos da alta e da baixa Guiné eram reunidos enquanto aguardavam serem embarcados. Na direção oposta, os portugueses (brancos e mulatos) viajavam de Cabo Verde e de São Tomé para alta e baixa Guiné, para captura de escravos, ouro e marfim. É de salientar que a produção do açúcar no Atlântico, bem como em outras regiões necessitaram de um número muito grande de braços humanos para seu desenvolvimento, que necessitava de mão de obra barata e numerosa. Portugal nesta época se encontrava impossibilitado de oferecer mão de obra em quantidade suficiente, pois passava por situações delicadas relativas à sua população, devido à peste negra de destruiu quase um terço dessa, além da constante guerra com o país vizinho. A cultura da cana sacarina exigiu não só grandes tratos de bom terreno como também de mão de obra abundante e fácil de recrutar. Foram essas exigências que levaram para os trópicos os portugueses, e em toda parte onde a cultura da cana-de-açúcar foi implantada, estava ligada ao trabalho de $\operatorname{cativos}^{21}$.

As técnicas usadas ao longo dos séculos em uma determinada região estavam sempre correlacionadas com outras regiões produtoras de açúcar. Por isso ao importarem diferentes técnicos para novas regiões produtoras, ou como se dizia na época: mestres de açúcar implicariam também a transplantação das técnicas das atividades, uma vez que a primeira estaria vinculada a segunda. Muitas das técnicas usadas no mediterrâneo na produção açucareira surgiram também na ilha da Madeira, e posteriormente nas ilhas de São Tomé e Príncipe e no Brasil. Embora houvesse uma

\footnotetext{
${ }^{19}$ GODINHO, Vitorino Magalhães. Os descobrimentos e a economia mundial. Lisboa: Editorial Presença, 1963. v. 4. p. 98-99.

20 BOXER, Charles Ralph. Relações raciais no Império colonial português: 1415-1825. Porto: Afrontamento, 1988. p. 14.

${ }^{21}$ TENREIRO, Francisco. A Ilha de São Tomé. Lisboa: Junta de Investigações do Ultramar, 1961, p. 68.
} 
correlação nas técnicas implantadas em diferentes locais, devido às situações encontradas em diferentes países, algumas dessas foram adaptadas as condições encontradas na produção local ${ }^{22}$. Citando Godinho, em São Tomé, existiam alçapremas, trapiches a força escrava e animal e engenhos d'água, por volta de 1506 começa a fase industrial do açúcar. $\mathrm{O}$ autor afirma que:

As plantações devem ter começado em 1485 ou pouco depois, mas durante uns vinte anos a transformação industrial limitou-se ao espremer a cana, fabricando assim tão só um suco grosseiro; tal transformação reduzida efetuar-se-ia em alçapremas, talvez ainda num outro lugar o trapiche de bestas (movidas pelos escravos) e não é impossível que se montassem moendas de água, mas sem o resto do equipamento industrial ${ }^{23}$.

As características de São Tomé, demonstraram um conjunto de condições que propiciou tais instalações, onde a existência de água em abundância, lenha e mão de obra, levaram os colonos a se adequarem em algumas técnicas, fazendo com que as mesmas fossem mais propicias ou viáveis para aquela região. $\mathrm{O}$ avanço da técnica vem de certa forma, com o avanço crescente do processo de competição, e nesta época já se fazia necessário, assim as inovações técnicas passaram a exigir um maior aperfeiçoamento no processo de trabalho. Creio que a medida que aumentava a demanda pelo bem, havia uma necessidade maior de melhorar o sistema produtivo bem como as técnicas ali implantadas. Valeria aqui destacar que não bastariam boas terras e abundância de mão de obra, clima favorável e todas as características mencionadas para o sucesso do açúcar, vale lembrar que existiu outro fator muito relevante e que sem este, talvez o comércio não conhecesse tais sucessos: a grande demanda pelo produto. A demanda e o preço do açúcar no mercado internacional foram de fundamental importância, pois a coroa portuguesa procurava um produto com estas características. Por outro lado, pois por volta dos anos 1400 ou um pouco mais tarde, havia uma parceria de financiamento entre Portugal e os banqueiros italianos - em particular, os florentinos - estabelecidos em Lisboa e na Antuérpia o que provavelmente havia

\footnotetext{
${ }^{22}$ O primeiro engenho de açúcar registrado em território português pertencente a Diogo Vaz de Teive, escudeiro do Infante D. Henrique, construído em 5 de Dezembro de 1452. A força motriz deste engenho era a água da Ribeira. Ver: Tombo $1^{\circ}$ do registro Geral da Câmara Municipal do Funchal, Doc. 2.

${ }^{23}$ GODINHO, Vitorino Magalhães. Os descobrimentos e a economia mundial. Lisboa: Editorial Presença, 1963. v. 4. p. 96.
} 
deixado o reino português endividado. $\mathrm{O}$ valor dos empréstimos seriam, posteriormente, reembolsados em espécie ou em mercadorias importadas do além-mar ${ }^{24}$.

Outro problema enfrentado por Portugal era o fator ecológico, pois sendo um país agrícola precisava de terras boas, capazes de produzir o que mais se consumia localmente, não obstante sem grande sucesso ocorria. Havia uma crescente escassez de cereais, em particular o trigo, no mercado, de norte ao sul de Portugal e isso ocorreu por conta da valorização do produto em quase toda Europa. Por conta de problemas ecológicos e de estrutura, a idade média fez com que grande parte Portugal não se encontrasse cultivada, havia uma irregularidade estrema de chuvas, com momentos de grandes precipitações e outros momentos moderados, sem contar a existência de poucos rios navegáveis em toda sua extensão e as oscilações violentas de nível de água. No final da idade média a população de Portugal não ultrapassava um milhão de pessoas ${ }^{25}$. A saída para seus problemas seria encontrar novas terras cultiváveis. Inicialmente acredita-se que a conquista de Ceuta, seria uma das sinalizações da abertura da expansão ultramarina, que marcaria profundamente o início de grandes descobertas. Apesar de haver várias motivações que levassem os portugueses a invadirem Ceuta, certamente um dos mais fortes seria se apoderarem da grande presa, que foi o mercado de ouro dos Mouros. Ceuta interessava também aos portugueses por possuir uma ótima localização, ficava no final da rota das caravanas árabes que transportavam ouro, e era também por esta região que se dirigiam alguns camelos carregados das especiarias vindas do oriente destinado ao mercado europeu ${ }^{26}$. Na verdade, a principal finalidade dessa conquista se justificaria para proteger os piratas portugueses e combater outros piratas, afim de apoderarem-se da mercadoria. Todavia, as conquistas não pararam por aqui, uma próxima presa seria a cidade de Tanger que acabaria em uma grande tragédia, com a derrota dos portugueses pelos Mouros e a morte do Infante Dom Fernando, filho mais novo do Rei Dom João I.

\footnotetext{
${ }^{24}$ OGOT, Bethwell Allan (Ed.). História geral da África, V: África do século XVI ao XVIII. Brasília: UNESCO, 2010. p.6.

${ }^{25}$ Em Portugal, como em outros lugares, a Peste Negra de 1348-49 provocou enorme mortalidade, e a longa Guerra com Castela, de 1383 a 1411, deve ter acarretado efeitos adversos sobre as populações fronteiriças. Mas a resistência humana a calamidades nacionais desse tipo está suficientemente confirmada, e a cifra de um milhão deve ter sido atingida e ultrapassada por volta de 1450. As únicas cidades de alguma importância quanto ao tamanho, ao norte do rio Tejo, eram Porto, Braga, Guimarães, Coimbra e Bragança, das quais a primeira era de longe a maior, com a população de certa de 8 mil habitantes. Ver: BOXER, Charles Ralph. O império marítimo português, 1415- 1485. Tradução de Anna Olga de Barros Barreto. São Paulo: Companhia das Letras, 2002. p.18.

26 ALBUQUERQUE, Luís de; MAGALHÃES, Ana Maria; ALÇADA, Isabel. Os descobrimentos portugueses: viagens e aventuras. Lisboa: Caminho, 1991. p. 25.
} 
Embora Ceuta houvesse trazido muitas riquezas, ela não satisfazia por completo as necessidades básicas que motivavam as conquistas portuguesas, pois o maior problema era a escassez de alimentos, em particular os cereais, essa questão persistia. Após a conquista da Ceuta, houve várias tentativas de cultivo de cereais, não obstante, elas seriam totalmente destruídas pelos mouros e isso deixava os portugueses numa situação bastante frágil. Assim, a conquista das ilhas do Atlântico que possuía terras férteis e em grande extensão era fundamental. Descobertas as ilhas de Madeira e de Açores - primeiras ilhas do Atlântico descobertas pelos portugueses - a produção de trigo e outros cereais panificáveis foram implantados em primeira mão, e em todas as regiões que se mostravam propicias para fazê-lo. Outras ilhas do Atlântico não tiveram sucesso com estes cereais, como a ilha de Cabo Verde e de São Tomé e Príncipe, onde a situação ecológica desses países era pouco propicia para esse tipo de agricultura. Em Cabo Verde, porque a terra era muita seca, os cereais não germinavam e em São Tomé, o produto germinava, porém acabava não frutificando. Ainda no auge da agricultura dos Cereais nas ilhas da Madeira e dos Açores, as regiões abastecedoras de açúcar do oriente são abaladas por acontecimentos comprometedores do seu rico monopólio, os portugueses aproveitaram essa fragilidade e iniciaram a cultura da cana sacarina na ilha da Madeira. Grandes investimentos foram realizados priorizando grandemente este novo produto, abafando desta forma o ramo de agricultura dos cereais, que antes havia sido a mola real do movimento expansionista ${ }^{27}$. Instado na Ilha da Madeira em 1452, três anos depois, ou seja, em 1455 a produção do açúcar se eleva a 6.000 arrobas, e o mesmo ocorreu em outras ilhas recém-descobertas no Atlântico.

\footnotetext{
${ }^{27}$ A escassez do cereal foi dos uns dos primeiros focos da expansão ultramarina, depois a escassez do ouro e outros metais preciosos que acarretavam a falta de moeda. O problema do ouro em parte seria resolvido com a conquista de Ceuta, pois foram saqueadas grande parte das relíquias dos mouros, além da pirataria dos barcos portugueses frente aos barcos de outros países, que iam vender produtos ou que passavam perto da região. O problema do cereal foi resolvido em parte, porém outras ilhas como Cabo Verde e São Tomé e Príncipe não obtiveram sucessos. A introdução da cana-de-açúcar na Madeira surge no momento de instabilidade das potências que antes a produziam, devido à grande demanda deste novo produto os portugueses expandiram sua produção para outras ilhas recém-descobertas. Ver: ALBUQUERQUE, Luís de; MAGALHÃES, Ana Maria; ALÇADA, Isabel. Os descobrimentos portugueses: viagens e aventuras. Lisboa: Caminho, 1991. p. 48-49.
} 


\section{CAPITULO I}

\section{1 - Do descobrimento à implantação da produção açucareira.}

A descoberta e consequentemente a ocupação das ilhas do Atlântico constituiu um episódio da expansão comercial europeia, que marcou profundamente $o$ desenvolvimento da Europa ocidental, bem como a ligação do mundo africano com outros países, tendo papel preponderante a costa africana. Tais descobertas estariam ligadas a política econômica portuguesa do século XV, que tinha como uma das metas, o descobrimento e exploração da costa africana. Essas metas resultaram, em grande medida, na expansão agrícola das ilhas do Atlântico e a abertura das rotas marítimas das Índias orientais. Nas ilhas do Atlântico, as descobertas e ocupações não se derem por pressões demográficas como fora o caso da Grécia, ou de grandes movimentos de populações determinadas pela ruptura de um sistema cujo equilíbrio se manteve pela força - caso de migrações germânicas em direção ao sul da Europa. A descoberta nessas ilhas seria resultado, segundo Celso Furtado ${ }^{28}$, do comércio interno europeu que estava em intenso crescimento a partir do século XI e que havia alcançado um elevado grau de desenvolvimento no século XV, quando as invasões turcas começaram a criar crescentes obstáculos às linhas orientais de abastecimento de produtos de alta qualidade, inclusive manufaturas. O restabelecimento de linhas comerciais, contornando o obstáculo otomano, constitui sem dúvidas a maior realização dos europeus na segunda metade do século XV. Para o mesmo autor a ocupação economia, ou interesse em desenvolver indústrias em São Tomé e posteriormente no Brasil, se deu em grande medida "a pressão política exercida sobre Portugal e Espanha pelas demais nações europeias, nas quais prevalecia o princípio de que os espanhóis e os portugueses não tinham direito senão naquelas terras que houvessem ocupado" ${ }^{29}$. Nisso, pelo menos no findar do século $\mathrm{XV}$, momento que marcou os descobrimentos, esses dois países ibéricos haveriam de encontrar, via descobrimento, formas de se manter economicamente. A forma mais plausível, naquela época, seria apostar em algum produto valioso que houvesse grande demanda no mercado para que pudessem investir. Havia já alguns

\footnotetext{
${ }^{28}$ Celso Furtado nos mostra que "a exploração da costa africana, a expansão agrícola nas ilhas do Atlântico e finalmente a abertura da rota marítima das índias orientais, constituiu um fenômeno autônomo da expansão comercial europeia, em grande parte independente das vicissitudes crescentes criadas ao comércio do mediterrâneo pela penetração otomana". Ver: FURTADO, Celso. Formação Econômica do Brasil. $32^{a}$ ed. São Paulo: Companhia Editora Nacional, 2005. p. 15. Nota de rodapé.

${ }^{29}$ FURTADO, Celso. Formação Econômica do Brasil. 32 ed. São Paulo: Companhia Editora Nacional, 2005. p. 16.
} 
produtos que no cenário econômico internacional eram produzidos em grande escala por Portugal, como vinho e trigo, mas o destaque foi para o açúcar, que possuía preço muito atrativo e todo um conjunto de elementos favoráveis, como: abundância de terras e clima propícios para o seu desenvolvimento.

Para que o processo encontrasse viabilidade econômica e se enquadrasse nos propósitos coloniais, era necessário encontrar regiões que facilitassem a implantação de um sistema agrícola. Depois que as terras foram ocupadas, em primeira mão, o comércio a ser implantado já se encontrava com uma demanda alta no mercado consumidor, pelo menos para a necessidade então requerida, por outro lado as terras usadas no plantio de cana-de-açúcar eram baixas e planas, muito adequadas para desenvolvimento do processo, além da presença dos rios, cujas águas serviriam para regar a plantação, movimentar os engenhos e escoar os detritos. Para o caso de São Tomé e Príncipe, a descoberta fez-se na região noroeste, uma região montanhosa e menos propícia para instalação da produção. Não obstante, anos depois da descoberta das ilhas, transferiu-se para região nordeste, região que se apresentava ideal para a cultura: grande extensão de terras baixas e planas, com numerosos ribeirões e lagos. Os estabelecimentos dos colonos estavam naquela época expandindo-se rapidamente cerca de três milhas em direções diferentes, certamente para regiões que tivessem pequenas ribeiras ${ }^{30}$.

A data exata da introdução da cana-de-açúcar em São Tomé é incerta, o que se sabe é que a mesma estaria relacionada a judeus levados para essas ilhas em 1493. O povoamento teria sido feito à custa dos meninos judeus que o cristianismo procurou chamar a si, afastando-os dos pais e enviando-os para os lagartos ${ }^{31}$. Foram essas levas de colonos judeus que, por inúmeros motivos foram levadas para essas terras longínquas, como formas de se estabelecer nelas e criar riquezas que, na época era um dos propósitos da coroa portuguesa.

\section{1 - Descoberta da Ilha de São Tomé e Príncipe}

A descoberta das ilhas do Atlântico estaria vinculada a vários fatores. Segundo Tenreiro (1961,57), os descobrimentos das ilhas do Atlântico e do Golfo da Guiné,

\footnotetext{
${ }^{30}$ Descrição de vários lugares nas quais foram feitas as plantações, incluindo cana-de-açúcar, inhame e fazenda de porcos de João de Melo. Arquivo Nacional da Torre de Tombo - ANTT. CC, 11-22 - 68, de 28 de julho de 1509.

${ }^{31}$ TENREIRO, Francisco. A Ilha de São Tomé. Lisboa: Junta de Investigações do Ultramar, 1961.
} 
verificaram-se entre 1471 e 1472. No entanto, nomeadamente: Ano Bom; Santo Antônio ou Antão e São Tomé teriam sido encontradas numa mesma expedição, respectivamente entre os dias 1 e 17 de janeiro e 21 de dezembro, e de acordo com o calendário Santos Monique, justificam os nomes como foram batizados, e a ilha Formosa, a ilha maior, foi descoberta mais tarde ${ }^{32}$.

Apesar das ilhas descobertas no Golfo da Guiné apresentarem quase as mesmas características, a ilha de São Tomé parece ter sido a mais privilegiada pelos colonos portugueses. Tudo leva a crer que, pelo fato da ilha de São Tomé encontrar-se mais afastada do continente africano, trouxesse certa vantagem em comparação com outras ilhas da mesma mediatriz. São Tomé apresentava, em relação a outras ilhas, nas palavras de Tenreiro $^{33}$ : situação ideal favorecida pelas correntes marítimas e pela circulação atmosférica, que a tornavam um ponto de escala para navios que demandassem ou viessem do hemisfério sul. Pressupõe-se que D. João II já tivesse informações concretas sobre apresentação natural das ilhas do Golfo da Guiné e sob este aspecto, a ilha de São Tomé apresentava condições que lhe eram favoráveis. Além disso, já era um sonho do D. João II, em ver um novo caminho para a índia, que se deve ao início da colonização da ilha de São Tomé. Fernando Pó ou a Ilha Formosa, possui uma superfície, de aproximadamente duas vezes e meio maior que a ilha de São Tomé e ainda assim, não era o centro das atenções dos colonos. O relevo de Fernando Pó é menos caprichoso e apresentava-se maciço e pouco penetrável, diferentemente de São Tomé, cuja região nordeste possui menos inclinação para o mar o que permitiu aos seus colonizadores uma possibilidade de fixação em terras fáceis de abrir e onde os ribeirões e lagos abundavam apresentando diversidade de fauna e muitas chuvas.

Fernando Pó apresentava-se bem diferente de São Tomé, sendo que se caracterizava por uma época de chuva, a que se seguia por um período seco mais escaldante, muitas vezes trazido por ventos quentes e poeiras continentais. Uma das desvantagens da Ilha Formosa em relação a São Tomé, estava no fato dessa se encontrar povoada por habitantes do continente africano, provavelmente o foco do povoamento eram terras livres, a semelhança do que fizeram nas ilhas encontradas anteriormente,

\footnotetext{
${ }^{32}$ TENREIRO, Francisco. A Ilha de São Tomé. Lisboa: Junta de Investigações do Ultramar, 1961. p. 57.

${ }^{33}$ TENREIRO, Francisco. A Ilha de São Tomé. Lisboa: Junta de Investigações do Ultramar, 1961. p. 58.
} 
como dos Açores e a da Madeira. Essas foram sem dúvida, na visão de Tenreiro ${ }^{34}$ a situação privilegiada da ilha de São Tomé e Príncipe em relação as outras ilhas, o aspecto de ser despovoada e as características do seu relevo que explicassem que São Tomé no Atlântico à beira do hemisfério sul, tenha exercido grande atração sobre os portugueses e se tenha se tornado ponto de encruzilhada de transportes provenientes de Portugal e da costa da África, primeiro, e da Índia e do Brasil, depois.

A ocupação da costa africana se deve principalmente a conquista da cidade de Ceuta, no norte da África, em 1415, que gerou grande interesse, pelo fato de já conhecerem o território, e assim, possuírem ponto de partida para expansão ultramarina portuguesa.

Para muitos historiadores portugueses, essas conquistas tinham como objetivo abrir caminho na busca do ouro do Sudão e controlar incursões piratas dos árabes nas costas de Portugal, e para outros historiadores, foi uma grande expedição da nobreza, promovida pelo rei, em busca de saque e aventura ${ }^{35}$.

A ocupação dessas terras deveu-se ao privilégio de já terem conquistados Ceuta, e uma vez a conquistado, no momento que vivia a economia portuguesa de muita fragilidade, fizeram essa expedição em direção a lugares que já haviam tido algum conhecimento e pudessem tirar algum proveito econômico. Certamente, se Portugal não conhecesse nada dos países a que se dirigiam, essas expedições seriam muito mais difíceis e não alcançariam o sucesso que alcançaram.

Se os portugueses não avançaram territorialmente, a coroa organizou o comércio africano, estabelecendo o monopólio real sobre as transações com ouro, obrigando a cunhagem em uma casa da moeda e criando também, por volta de 1481, a Costa da Mina ou Costa de Guiné, como alfândega especial para o comércio africano. Da costa ocidental africana, os portugueses levavam pequenas quantidades de ouro em pó, marfim, cujo comércio se achava até então em mãos de mercadores árabes e era feito através do Egito, a variedade de pimenta chamada malagueta e, a partir de 1441, sobretudo os escravos. Esses foram no comércio, encaminhados a Portugal, sendo utilizados em trabalhos domésticos e ocupações urbanas ${ }^{36}$.

\footnotetext{
${ }^{34}$ Tenreiro mostra-nos um conjunto de fatores que leva a coroa portuguesa a ter São Tomé como ilha privilegiada, apesar de quase todas elas serem descobertas numa mesma época e possuírem características muitas similares. Ver: TENREIRO, Francisco. A Ilha de São Tomé. Lisboa: Junta de Investigações do Ultramar, 1961. p. 59.

${ }^{35}$ FAUSTO, Boris. História do Brasil. $2^{\text {a }}$ ed. São Paulo: Editora da Universidade de São Paulo, 1995. p. 28.

${ }^{36}$ FAUSTO, Boris. História do Brasil. 2 a ed. São Paulo: Editora da Universidade de São Paulo, 1995. p. 29.
} 
A descoberta das ilhas atlânticas parece não ser um acidente, pois já havia toda uma aventura para que proporcionasse essas descobertas. Albuquerque ${ }^{37}$, afirma que nove anos depois da morte do infante D. Henrique, o rei D. Afonso V entregou a Fernão Gomes, um Burguês de Lisboa, a missão de continuar os Descobrimentos. Concedia-lhe em exclusivo o direito de comerciar com os habitantes da costa ocidental africana. Ele comprometia-se a descobrir pelo menos cem léguas da costa por ano e a pagar à coroa a quantia anual de duzentos mil réis. Assim, Fernão Gomes cumpriu rigorosamente o prometido. Os seus navios descobriam a faixa de terra desde Serra Leoa até ao cabo de Santa Catarina, incluindo as ilhas de São Tomé e Príncipe. Os principais navegantes que estavam ao serviço de Fernão Gomes eram João de Santarém, Pêro Escobar, Fernão Pó, Lopo Gonçalves e Rui Sequeira. De acordo com Tenreiro ${ }^{38}$, a ilha de São Tomé é doada em 1485 a João de Paiva, e isso trouxe consigo parte do povoado que antes era destinada à metrópole. $\mathrm{O}$ mesmo autor acredita que, desembarcaram inicialmente em Ano Bom e no ano seguinte, no porto de Ponta Figo, na região noroeste da ilha, onde fundaram uma pequena povoação e na carta de doação, entre outros privilégios que se concedem aos povoadores, está o de poderem negociar em terras formes nas cinco ribeiras que estão lá da fortaleza de minas, ao mesmo tempo recomenda-se que se proceda à plantação de cana-de-açúcar ${ }^{39}$. Isso aconteceu na realidade, e o povoamento bem como as instalações coloniais deveria ser feito em algum lugar e em função de uma cultura lucrativa, dando poderes aos moradores de resgatarem o que fosse necessário na costa africana, e a cultura de cana-de-açúcar se encaixava perfeitamente no requisito preestabelecido, que encontrou nessas terras numerosas mão de obra. Tudo leva a crer que João de Paiva não governava só. As ilhas de São Tomé e Príncipe eram governadas em paralelo com sua filha Mécia de Paiva, que detinha metade do terreno na ilha. A partir de 1486 as ilhas seriam assumidas por João Pereira, considerado, assim um dos primeiros moradores ali instalados, como indica Tenreiro:

Logo em janeiro de 1486 dá ao rei a João de Paiva metade do terreno da ilha, o que em Março do mesmo ano, concede à filha deste, Mécia de Paiva. Entre os primeiros moradores figuraria um tal de João Pereira, pois quatro anos depois é lhe dada a capitania da ilha de São Tomé, invocando-se para tal os serviços que ali prestara; porque se

\footnotetext{
${ }^{37}$ ALBUQUERQUE, Luís de; MAGALHÃES, Ana Maria; ALÇADA, Isabel. Os descobrimentos portugueses: viagens e aventuras. $5^{\mathrm{a}}$ ed. Lisboa: Caminho, 1991. p. 53.

${ }^{38}$ TENREIRO, Francisco. A Ilha de São Tomé. Lisboa: Junta de Investigações do Ultramar, 1961. p. 59.

${ }^{39}$ Ibid., p. 58.
} 
não invoca qualquer outra razão, é de presumir que João de Paiva e a filha falecido $\mathrm{ja}^{40}$.

Após o término do contrato de Fernão Gomes, que se deu em 1474, o rei mostrou-se muito satisfeito com os serviços prestados pelo comerciante e para recompensá-lo, deu-lhe um título de nobreza e o Brasão de armas. O contrato não foi renovado, e o seu termo foi mesmo antecipado de alguns meses, porque o príncipe herdeiro, D. João, o futuro rei D. João II, quis ocupar-se pessoalmente dos descobrimentos. Provavelmente, pelas instabilidades na governança, o futuro rei quis se ocupar pessoalmente pela administração de todos seus bens. Filipe Thomaz:

O que mais fere a atenção não é, contudo, a fixação nesse objetivo, mas o carácter concentracionário das expedições: outrora, quando a iniciativa era senhoril ou burguesa, realizava-se uma multidão de pequenas expedições, que lenta e gradativamente iam penetrando no desconhecido; agora é a coroa que organiza grandes expedições, três (no Máximo quatro, se tem razão Carmem Radulet) que apenas no espaço de um lustro devassam tudo de costa africana ficara por descobri, avançando em cinco anos sensivelmente tanto outrora se avançava em $25^{41}$.

A maior preocupação seria que, apesar de D. João possuir pretensões nas regiões recém-descobertas, provavelmente o futuro rei e seus conselheiros conheceriam vagamente a imensidão daquelas sobre seu comando e essas dispersões sobre a administração do um único homem inviabilizaria a dinâmica tornando mais difícil a situação do reinado.

As riquezas que os navegadores traziam da África começaram a despertar interesse e curiosidade de outros povos, particularmente dos castelhanos. Embarcações dos países vizinhos aventuraram-se em direção ao golfo da Guiné a fim de obterem lucros idênticos ao dos portugueses. O príncipe D. João convicto de que naquela região só Portugal tinha direito de comercializar, tomou medidas drásticas ${ }^{42}$. Ele próprio realizou expediente a fim de verificar qual a melhor maneira de incluir peças de artilharia a bordo. As caravelas passaram então a dispor uma espécie de bomba, que lançavam projeteis junto à linha de água. Organizou esquadras de patrulha que enviou

\footnotetext{
${ }^{40}$ Ibid., p. 59.

41 THOMAZ, Luís Felipe Ferreira Reis. De Ceuta a Timor. Linda-a-velha: Difel, 1994.

42 ALBUQUERQUE, Luís de; MAGALHÃES, Ana Maria; ALÇADA, Isabel. Os descobrimentos portugueses: viagens e aventuras. $5^{\mathrm{a}}$ ed. Lisboa: Caminho, 1991. p. 56.
} 
para costa ocidental africana e deu ordem aos capitães para que afundassem os navios estrangeiros que ali encontrassem ${ }^{43}$.

É difícil precisar a data do descobrimento dessas ilhas, pois, até o presente, não temos documentações que comprove uma data, na verdade, as datas das descobertas são baseadas nas viagens do reinado do D. Afonso, provavelmente efetuado entre os anos de 1496 e 1472. Foram os navegadores portugueses João de Santarém e Pero Escobar que, por cargo do mercador Fernão Gomes, e em cumprimento do contrato que este celebrava com o Rei de Portugal, encontraram a ilha de São Tomé, provavelmente em 1470, e a do Príncipe, a que chamaram primeiramente de Santo Antão, no ano seguinte, na viagem de volta, encontrando-as ambas desabitadas. A instalação foi feita na região noroeste, próximo a Ponta Fico, porém como nesta não se apresentava propicia para os objetivos ali destinados, transferiu-se para região nordeste. A transferência dessa povoação para região nordeste deve-se a maior extensão de terra baixas, o que permitia maior desenvolvimento de culturas ali instaladas e de fácil penetração para o interior, sem contar que a região possuía estrutura natural para construção de excelentes portos de comércio. A região noroeste, possui muitas montanhas o que inviabilizava a instalação de um sistema produtivo.

De acordo com princípio de ampla descoberta administrativa adotada por Portugal no início da expansão ultramarina, foi a ilha de São Tomé em 1485, concedida em doação a João de Paiva, outorgando-se vários privilégios aos primeiros povoadores. As naturais dificuldades que o donatário encontrou no território deserto, coberto até própria orla marítima de exuberante e intrigada vegetação, não permitiram que este tirasse quaisquer frutos da sua doação, da qual desistiu, como aliás veio a suceder também, com o novo donatário, nomeado em 1490.

Só em 1493 o terceiro donatário, Álvaro de Caminha, conseguiu fixar na ilha alguns colonos que se decidiram à agricultura de cana-de-açúcar, que importaram da ilha da Madeira. O regime de donatários durou em São Tomé até 1522, data que a ilha passou a ser administrada pela Corroa. A ilha do Príncipe foi concedida em 1500 a Antônio Carneiro, em cuja família se manteve a doação até 1573, data em que terminou

\footnotetext{
${ }^{43}$ Nesta época havia muitas riquezas aflorando no mundo atlântico, em torno de toda a costa África e nas Américas, e isso provocou em outros países europeus cobiça e interesse pelas novas regiões recémdescobertas. E como uma forma de garantir ou controlar essas riquezas, o Príncipe, futuro Rei de Portugal, se encarregou da administração do reinado. É difícil saber se este seria o melhor caminho ou solução, pois como o império português era muito extenso, talvez isso dificultasse no processo administrativo. Ver: ALBUQUERQUE, Luís de; MAGALHÃES, Ana Maria; ALÇADA, Isabel. Os descobrimentos portugueses: viagens e aventuras. $5^{\text {a }}$ ed. Lisboa: Caminho, 1991.
} 
o regime de donatários na ilha e esta foi integrada, como sucedera a São Tomé, nos bens da coroa. A economia das ilhas baseava-se, neste início da colonização na exportação do açúcar ${ }^{44}$.

Desde o final do século XIV, havia em Portugal uma corrente crescente pela pesca marítima, época em que a pele de alguns peixes apresentava demanda nos mercados de couro para calçados e outros utensílios. Provavelmente esses pescadores devem ter avistado algumas ilhas. Para Francisco Tenreiro ${ }^{45}$, pouco se sabe quanto da data do descobrimento da ilha de São Tomé, tudo se baseia na data e no nome dos descobridores. Os historiadores portugueses são levados a supor que as mesmas foram datadas entre 1471 e 1472, Ano Bom, Santo Antônio (ou Santo Antão) e São Tomé teriam descobertos na mesma expedição, respectivamente nos dias 1 e 17 de janeiro e 21 de dezembro. A opinião geral dos historiadores indica que a descoberta tenha sido em 21 de dezembro de 1470, consagrando ao santo que tornou o nome, e a do Príncipe no dia 17 de janeiro do ano seguinte, o nome também em alusão ao Santo Antão, de quem a ilha teria usado o nome, até receber o que tem atualmente, em homenagem ao príncipe primogênito do Dom Afonso V, que havia de reinar com o nome do dom João II.

Mas as datas das descobertas das ilhas do Atlântico apresentam algumas controvérsias, para muitos autores as datas seriam anteriores as datas oficias e para outros o descobrimento teria sido feito posterior a mesma data. Existem alguns que indicam que talvez este fato se constate no tratado de paz entre Afonso V e os Reis Católicos, Fernando e Isabel, assinado em 4 de setembro de 1478. Segundo Lains e Silva ${ }^{46}$, o tratado contém referências, no seu artigo $7^{\circ}$, as ilhas de Madeira, Porto Santo, Açores, Flores e Cabo Verde, e acrescenta: quaisquer outras ilhas que se acharem descobertas e o forem das ilhas das Canárias para baixo contra a Guiné pertenceriam à coroa portuguesa. O mesmo autor salienta que no Globo Behaim, figurava umas legendas juntas das Ilhas do Oceano, na qual constava São Tomé Príncipe, em que Cortesão afirmava o seguinte: essas ilhas foram achadas com os navios que o rei de Portugal enviou para estas paragens do país de mouros em 1484. Nesta passagem, julgo se São Tomé e Príncipe houvessem sido descobertas em 1484, acidentalmente, em uma

\footnotetext{
${ }^{44}$ AGÊNCIA GERAL DO ULTRAMAR (Portugal). São Tomé e Príncipe: pequena monografia. Lisboa: Agência Geral do Ultramar, 1969. p. 38.

${ }^{45}$ TENREIRO, Francisco. A Ilha de São Tomé. Lisboa: Junta de Investigações do Ultramar, 1961.

${ }^{46}$ LAINS E SILVA, Hélder. São Tomé e Príncipe e a cultura do café. Lisboa: Junta de Investigações de Ultramar, 1958. p. 42.
} 
das viagens para os mouros. Nas escritas de Duarte Pacheco do século XVI, situava as datas do descobrimento no reinado do Dom Joao II, depois de 1481: "ao mar do cabo de Lopo Gonçalves, sessenta léguas de caminho ao loes-noroeste deste cabo, está uma ilha que se chama São Tomé, a qual mandou descobrir sereníssimo Rei Dom João, o segundo de Portugal, e a Povoou". E relativo à ilha do Príncipe, dizia: "E também o dito Rei Dom João descobriu esta ilha e a povoou..." 47 . O que parece contraditório é que maioria das tradições das descobertas dessas ilhas revela que a ilha hoje que se chama ilha do Príncipe, ao descobri-la se chamava da ilha de Santo Antônio, e só passou a ser chamado da ilha do Príncipe, com a doação da mesma ilha ao príncipe herdeiro do Dom Afonso V, posteriormente Rei Dom João. As contradições das descobertas vão ainda mais longe, autoridades como Gago Coutinho, sustenta que em 1470, já se havia atingido São Tomé junto ao Equador, afirmando assim que os documentos e depoimentos citados legitimam tais fatos ${ }^{48}$. Em 1485, D. João II introduziu o sistema de capitanias e nomeou como capitão donatário João de Paiva, que partiu da Metrópole com aqueles que seriam os primeiros povoadores da ilha. Em setembro do mesmo ano, uma carta régia determinou os deveres, e entre outros privilégios, que os moradores poderiam resgatar nos cinco rios além da Fortaleza de São Jorge da Mina, assim como ressaltou a necessidade do desenvolvimento do cultivo da cana-de-açúcar na região ${ }^{49}$. Tudo indica que o povoamento da ilha de São Tomé se inicia cerca de catorze anos depois do descobrimento e que as restantes só foram colonizadas muito mais tarde, exceção da ilha do Príncipe, cujo desenvolvimento se fazia à sombra da ilha de São Tomé $^{50}$. Tudo leva a crer que o descobrimento das ilhas do golfo da Guiné, mas especificamente, São Tomé e Príncipe estariam ligados ao reinado do Dom Afonso V, provavelmente ocorrido entre os anos 1469 e 1472, que na época, entregou a Fernão Gomes, um burguês de Lisboa, a missão de continuar os descobrimentos. Concedia-lhe, no entanto, o exclusivo direito de comerciar com os habitantes da costa ocidental africana, assim comprometido em descobrir pelo menos cem léguas da costa por ano e como recompensa, pagaria à coroa a quantia anual de duzentos mil réis ${ }^{51}$.

\footnotetext{
${ }^{47}$ LAINS E SILVA, Hélder. São Tomé e Príncipe e a cultura do café. Lisboa: Junta de Investigações de Ultramar, 1958. p. 42.

${ }^{48}$ LAINS E SILVA, Hélder. São Tomé e Príncipe e a cultura do café. Lisboa: Junta de Investigações de Ultramar, 1958. p. 43.

${ }^{49}$ TENREIRO, Francisco. A Ilha de São Tomé. Lisboa: Junta de Investigações do Ultramar, 1961. p. 57.

${ }^{50}$ Por motivos que se desconhecem, a Ilha de São Tomé sempre esteve em uma administração paralela, na época em que a capital do país foi transferida para aquela ilha irmã.

${ }^{51}$ ALBUQUERQUE, Luís de; MAGALHÃES, Ana Maria; ALÇADA, Isabel. Os descobrimentos portugueses: viagens e aventuras. $5^{\mathrm{a}}$ ed. Lisboa: Caminho, 1991. p. 153.
} 
Outra hipótese sobre a possibilidade da descoberta das ilhas tenha ocorrido entre 1481 e 1486, isto é, entre a subida ao trono de Dom João II e a outorga do primeiro foral aos colonos de João de Paiva ${ }^{52}$. De alguma forma, a descoberta das ilhas foi acompanhada, direta ou indiretamente ao processo de povoamento, um fato necessário decorrente da própria necessidade que se fazia sentir. Somente o terceiro donatário Álvaro de Caminha, em 1493, conseguiu fixar na ilha alguns colonos que se dedicaram a agricultura de cana-de-açúcar. A cultura de cana-de-açúcar, durante quase duzentos anos, foi o negócio que mais rendeu a coroa e aos colonos portugueses, e só veio a conhecer a sua decadência por conta, talvez da heterogeneidade da população, juntando com o espírito de ganância de muitos governadores e falta de preparação, bem como fatores que deram origem a constantes rixas e desentendimentos, que resultou em grande prejuízo e abando do território em direção a outras regiões, recém-descobertas e que possuíssem as mesmas características de São Tomé, em especial, para o Brasil.

\section{2 - Fatores que levaram a descoberta.}

O século XIV pode ser considerado o grande momento das descobertas dos oceanos, onde as rotas oceânicas foram traçadas e assim nasceria o mundo Atlântico. O interesse crescente pelo mundo Oriental estaria vinculado aos problemas do Mediterrâneo, tais como: secas, especiarias e os problemas do desvio para o ocidente dos capitais italianos, (genoveses e os florentinos), capitais que a progressão turca e o quase monopólio veneziano tornaram inativos no oriente ${ }^{53}$.

Para Godinho ${ }^{54}$ as causas da descoberta e a instalação no mundo Atlântico, deveram-se, antes, as condições peculiares dos próprios países. Para o autor, as viagens das descobertas e os primeiros estabelecimentos nas ilhas do Atlântico ao longo da costa africana parecem ser consequência de um conjunto de forças que distribuiremos por quatro rubricas. Primeiro, e já conhecido é a procura do ouro pela via marítima, imposta pela carência dos metais preciosos e a queda das rendas senhoriais. Em 1415

\footnotetext{
52 ALBUQUERQUE, Luís de; MAGALHÃES, Ana Maria; ALÇADA, Isabel. Os descobrimentos portugueses: viagens e aventuras. $5^{\mathrm{a}}$ ed. Lisboa: Caminho, 1991. p. 154.

${ }^{53}$ Nesta altura, os turcos e os venezianos cresceram muito financeiramente, instalando dessa forma uma maior participação no mercado produtor. Ainda que os genoveses e os florentinos (donos de grande reserva de capitais) quisessem investir, surgiu um novo concorrente que então monopolizara o mercado. Ver: GODINHO, Vitorino Magalhães. Portugal, as frotas do açúcar e as frotas de ouro (1670 - 1770). Revista de História, São Paulo, v.7, n. 15, p. 69-88, 1953.

${ }^{54}$ GODINHO, Vitorino Magalhães. Portugal, as frotas do açúcar e as frotas de ouro (1670 - 1770).
} Revista de História, São Paulo, v.7, n. 15, p. 69-88, 1953. 
portugueses comandados pelo próprio rei conquistaram aos mouros, a cidade de Ceuta, no norte da África, tanto que essa data, para muitos historiadores, inicia a expansão ultramarina. Neste evento estaria o principal motivo para a descoberta de outras regiões no Atlântico. A quem diga que a razão principal foi tentar dominar uma cidade rica em cereais, do que havia grande falta no reino de Portugal, outros dizem que desejo de conquistar a Ceuta teria nascido dos burgueses que se dedicavam ao comércio, já que viajavam com certa frequência ao norte da África com barcos carregados de mercadorias, ser-lhes-ia de maior utilidade dispor de um porto importante, abrigado e protegido por muralhas, para se instalarem e construírem armazéns ${ }^{55}$. Certamente Ceuta interessava aos portugueses porque havia uma localização excelente, além de ficar no final da rota das caravelas árabes que transportavam ouro. Era também a rota que fazia alguns cameleiros vindos do oriente com especiarias destinadas ao mercado europeu. Isso provavelmente seria uma estratégia ou uma oportunidade que os navios portugueses teriam de atacar os mouros, capturar a tripulação e apoderar de mercadoria. $\mathrm{Na}$ verdade, a conquista se justifica não só para combater os piratas mouros, mas também para proteger os piratas portugueses ${ }^{56}$. Parece que os motivos são vários e para se aproximar da verdade o melhor considerá-los a todos. Os motivos não faltaram para que os portugueses se lançassem ao mar. O principal era a crise crônica de cereal que vivia Portugal durante o século XIV e início de século seguinte. Na verdade, a falta deste produto, que era umas das principais fontes alimentícias, já se fazia sentir no reinado do Dom Afonso III, quando o mesmo proibiu em 1272 a exportação dos cereais pois havia escassez no reino, desde 1331 já se importava o produto. Durante os séculos XV e XVI agravavam-se o déficit de cereais, em especial o trigo, não só pelo abandono da agricultura metropolitana, que já era uma debilidade extrema, mas também pelas necessidades crescentes do consumo de pão a nível nacional e das fortalezas espalhadas no mundo ${ }^{57}$, como nos mostra Lains e Silva ${ }^{58}$ :

\footnotetext{
55 ALBUQUERQUE, Luís de; MAGALHÃES, Ana Maria; ALÇADA, Isabel. Os descobrimentos portugueses: viagens e aventuras. $5^{\text {a }}$ ed. Lisboa: Caminho, 1991. p. 24.

${ }_{56}$ ALBUQUERQUE, Luís de; MAGALHÃES, Ana Maria; ALÇADA, Isabel. Os descobrimentos portugueses: viagens e aventuras. $5^{\mathrm{a}}$ ed. Lisboa: Caminho, 1991. p. 25.

${ }^{57}$ LAINS E SILVA, Hélder. São Tomé e Príncipe e a cultura do café. Lisboa: Junta de Investigações de Ultramar, 1958. p. 45.

${ }^{58}$ LAINS E SILVA, Hélder. São Tomé e Príncipe e a cultura do café. Lisboa: Junta de Investigações de Ultramar, 1958. p. 46.
} 
Terras cobertas de maninho xerofíticas, de clima seco com má distribuição de chuvas ao longo do ano, só poeta de lírica sensibilidade podiam considerá-la um paraíso. Nas várzeas, as cheias incontroláveis de grandes rios; nas vastas planícies, a seca de Verão e as chuvas fora da estação; pelo norte do rio Tejo, serranias nuas de pedra à vista, não era propícias à agricultura e, portanto, as formas de viver estável. Terra pequena e agreste, por força nos havia de empurrar para o oceano em busca de pão. A dureza do país, todos nós conhecemos, embora mais a hajam notado olhos de estrangeiros habituados a panorama agrícolas de outras regiões europeias, viajando no Portugal que oferece à vista serranias areias e penedias interrompidas por campos nados apenas da tenacidade do povo trabalhador.

Não fica difícil buscar outras razões que pudesse levar os portugueses para o mar, se não o meio de saciar ou minimizar a falta de alimentos que cobria a população. Fenômenos idênticos se verificavam com os povos da agricultura itinerante, que sucessivamente vão abandonando por outros os campos agrícolas. Os portugueses foram os primeiros grandes nômades do mar, que cruzavam em todos os sentidos retalhando-o com rotas tão apertadas que não ficou terra, pedaço de vulcão ou ilhéu pedregoso e deserto que escapasse à sua insaciável curiosidade ${ }^{59}$.

E mediante toda a crise cerealífera, não bastasse ter iniciativa, pois muitas das soluções encontradas requeriam um dispêndio elevadíssimo. Em Portugal havia experiência nas águas do Atlântico, sabiam e conheciam o mercado de ouro nas regiões da áfrica do norte, mas para chegar lá precisariam de armamento, navios de alto porte bem como custo com alimentos para os marinheiros e toda a tripulação.

Por volta de 1470, Portugal teve que sustentar um conflito armado com Castela, conflito que acarretou ao reinado um custo elevadíssimo, piorando ainda mais sua situação financeira, que já se encontrava bem desfavorável, por conta do problema de seca e falta de cereais. Nesta época, havia uma superioridade temporária de sua frota e de seus movimentos diplomáticos. Assim, Portugal consegue eliminar Castela da África Ocidental, segundo os termos dos tratados de Alcaçovas e de Tordesilhas, os quais foram concluídos, respectivamente, em 1481 e em 1494, e, em virtude dos direitos exclusivos sobre a expansão econômica e política do sudeste do Atlântico, conferidos a Portugal pelo papa Alexandre VI.

João II e Manuel, os soberanos portugueses foram forçados a pedir auxílio aos grandes financiadores italianos e ao sul da Alemanha. Os banqueiros italianos estabelecidos em Lisboa e na Antuérpia, ou que

\footnotetext{
${ }^{59}$ LAINS E SILVA, Hélder. São Tomé e Príncipe e a cultura do café. Lisboa: Junta de Investigações de Ultramar, 1958. p. 47.
} 
possuíam agentes nessas cidades, outorgaram- lhes empréstimos em numerário ou em mercadorias, de valor considerável, que seriam, posteriormente, reembolsados em espécie ou em mercadorias importadas do além-mar. A partir de 1480, e talvez, mesmo mais cedo, alguns destes banqueiros como Bartolomeu Mar-Chioni, Sernigi e outros participaram ativamente das trocas comerciais com a África e, em consequência, retribuíram ao rei de Portugal. A contabilidade deste último, primeiro em Bruges, depois em Antuérpia, revela a estreita dependência financeira da Coroa frente as grandes empresas como aquelas dos Frescobaldi, Affaitati e Fuggers. (...) Os portugueses em 1525 começaram a encontrar dificuldades para achar ouro, mesmo na região de Elmina, provavelmente, nas costas africanas, já não dispunham do suficiente de mercadorias para oferecer em troca. ${ }^{60}$

Depois vem a necessidade de mão de obra, mais precisamente de escravos para plantação de cana e como força para mover engenho de açúcar que se ensaiavam, mesmo em Portugal, desde o começo de século XV. Há que se considerar o alargamento progressivo e voluntário nas áreas de pescas, sobretudo o papel que desempenhava a pesca marítima na economia portuguesa da idade media. Provavelmente essas ilhas já haviam sido primeiros descobertos pelos pescadores e só depois seriam descobertos (oficialmente) pelos pretensos descobridores. (...) A pesca marítima liga principalmente a caça à foca cujas peles eram matéria-prima para a indústria de calçados que no século XIV e no princípio do XV, estaria com uma demanda alta ${ }^{61}$.

Nas palavras do Godinho, a produção de açúcar parte também à conquista dos novos mundos, assim como ocorreu com a fabricação de têxteis e seus derivados como tingimento com novos materiais como o Pau Brasil. Em uma época onde a terra era principal fonte de renda, a maior parte da terra portuguesa não era cultivada, e isso ocorria por motivos ecológicos, como destaca Boxer:

Dois terços do solo português são demasiados rochosos, íngremes ou pedregosos para serem cultivados, ou então solo é tão pobre que produz apenas colheitas incertas e de baixa qualidade. A extrema irregularidade de chuvas, com precipitações, ora excessivas ou imoderadas, ora totalmente insuficientes, é outras das desvantagens naturais. São poucos os rios navegáveis em toda a extensão, e as oscilações violentas do nível das águas (às vezes de quase trinta metros entre cheia e vazante) encontram-se entre as maiores do mundo. As estradas eram péssimas, mesmo para padrões medievais; e as aldeias, em números relativamente reduzidos de vastas extensões de matagal, charneca e de descampados ou de florestas ${ }^{62}$.

\footnotetext{
${ }^{60}$ OGOT, Bethwell Allan (Ed.). História geral da África, V: África do século XVI ao XVIII. Brasília: UNESCO, 2010. p. 7.

${ }^{61}$ GODINHO, Vitorino Magalhães. Portugal, as frotas do açúcar e as frotas de ouro (1670 - 1770). Revista de História, São Paulo, v.7, n. 15, p. 69-88, 1953. p. 70.

${ }^{62}$ BOXER, Charles Ralph. O império marítimo português, 1415 -1485. Tradução de Anna Olga de Barros Barreto. São Paulo: Companhia das Letras, 2002. p. 18.
} 
Inicialmente o propósito que levou os portugueses a saírem em busca de alternativa econômica para o reino era o ouro e o cereal. Neste período, a cunhagem do ouro já era adotada sucessivamente por quase todas as cidades, regiões e países, sobretudo pela influência da cunhagem do florim e ouro florentino, em 1252, e do ducano de ouro veneziano, em 1280. Portugal não possuía no período nenhuma moeda de ouro nacional, isso era um grave problema; até o ano 1383 era um dos poucos reinos europeus que se encontrava nessa situação. Mediante a fragilidade da sua economia e da necessidade de emergir ou se igualar como potência, buscaram-se alternativas emergenciais.

Cedo instalada na Madeira a cana-de-açúcar produziu 6.000 arrobas em 1454, experimentava já no fim do século XV um extraordinário desenvolvimento açucareiro: 120.000 arrobas era o mínimo para exportação dessa época. Rapidamente por volta de 1505 a 1510, a produção açucareira da madeira mantém o nível de 200.000 arrobas anuais, dez anos depois atinge as 300.000 arrobas. Da Madeira, o açúcar conquistou Açores e São Tomé, no final do século XV está nas Canárias; em breve chegaria ao Brasil e as Antilhas ${ }^{63}$. Em 1490, a carta de doação da Ilha para João Pereira, também determinava que, assim como nos outros arquipélagos Atlânticos, as terras deveriam ser concedidas, através de sesmarias ${ }^{64}$.

\section{3 - Produção açucareira nas ilhas do Atlântico}

O surgimento do mundo Atlântico impactou consideravelmente os bens e produtos demandados na Europa até então e por consequência o comércio do açúcar que era praticado em outras regiões do mundo. Como já foi observado, o açúcar era também produzido no oriente, mas especificamente na região de Egito, Marrocos, e na península Ibérica. Antes do século XV, o açúcar era pouco conhecido e os mercados, não poderiam consumi-lo de forma regular por representar um produto de alto valor. Embora no século XV a produção açucareira já existisse, era processada de forma muito

\footnotetext{
${ }^{63}$ A gênese do mundo atlântico esta, pois em grande parte, ligada ao que Fernando Braudel chama muito apropriadamente da dinâmica do açúcar. Ver: GODINHO, Vitorino Magalhães. Portugal, as frotas do açúcar e as frotas de ouro (1670 - 1770). Revista de História, São Paulo, v.7, n. 15, p. 69-88, 1953. p. 71.

${ }^{64}$ SANTOS, Catarina Madeira. A formação das estruturas fundiárias e a territorialização das tensões sociais: São Tomé, primeira metade do século XVI. Studia, Lisboa, v. 54-55, p. 51-92, 1996. p. 60.
} 
restrita, atendendo um mercado consumidor limitado. Além disso, regiões como Marraquexe, preferiam o mel ao açúcar, preferência aprovada pela Própria Coroa. No mundo islâmico, por volta de 1342 - 1349, encontrava-se o açúcar muito mais difundido, em comparação ao mundo Atlântico. A ampliação do consumo muda consideravelmente durante o final do século XV e começo do XVI, quando ocorre a generalização do consumo de novas bebidas: chá da China, o café da Arábia e o cacau da América e em simultâneo, muito provavelmente, por conta da baixa do preço ${ }^{65}$.

Até a introdução e a produção açucareira nas ilhas no Atlântico, os portugueses se dedicavam mais intensamente à produção do trigo, em uma época a onde os preços praticados pelo produto valiam muito. $\mathrm{O}$ açúcar ainda não era muito conhecido, e era consumido pelas classes mais abastadas da Europa. A produção do trigo começa na Ilha da Madeira a onde já se produzira 3.000 moios em 1455, o que veio suceder ao açúcar. O desenvolvimento do açúcar ganhou espaço na medida em que foi sendo conhecido e expandindo, a sua produção se estabelece a partir 1460/1470, desenvolvendo de tal forma que essa cultura substitui a do trigo. A introdução do açúcar na ilha da Madeira foi feita por infante D. Henriques logo após o descobrimento, uma cultura que já era praticada na metrópole desde inícios do século XIV, na região do Algarves e no início do século XV houve tentativa de sua implementação nos arredores de Coimbra ${ }^{66}$.

Os povos na região do norte da África, nomeadamente os Mouros, haviam introduzido a cana-de-açúcar e o engenho tanto no Maghreb, quanto no Egito. Nesta região da África, a cana sacarina é introduzida desde a primeira década do século XII e na primeira metade do século seguinte, esta cultura continuava. As principais regiões produtoras, em Marrocos eram: Marraquexe e Suz, além de outras como a região ocupada pelos Beni Mezgana, do termo de Salé. Em Marrocos, no território de Marraquexe, tinham aproximadamente 40 engenhos, número maior do que em Suz, na primeira metade do século XIV, nos quais se produzia qualidades variadas de açúcar, entre eles o puro, refinado, alvíssimo e compacto, esta última que quase igualada ao açúcar cândi do Egito ${ }^{67}$. Parece-me um pouco confuso quando, em Marrocos já se tinha 40 engenhos, porém a produção do açúcar era reduzida, sendo que a justificativa seria

\footnotetext{
${ }^{65} \mathrm{O}$ consumo do açúcar em massa se deu por conta da baixa do preço, que foi um resultado da acumulação produtiva e da restrição do seu consumo. Ainda que houvesse muitas bebidas que necessitasse do açúcar como um bem complementar, o seu uso ainda seria restrito pois esse item era considerado como um artigo de luxo.

${ }^{66}$ LAINS E SILVA, Hélder. São Tomé e Príncipe e a cultura do café. Lisboa: Junta de Investigações de Ultramar, 1958. p. 80.

${ }^{67}$ GODINHO, Vitoriano Magalhães. Os descobrimentos e a economia mundial. Lisboa: Editorial Presença, 1963. v. 4. p. $70-71$.
} 
pelo fato desta região, a preferência ser o mel ao invés do açúcar e de possuírem um nível de organização baixa e uma desordem na sociedade, quer em Suz ou em Marraquexe.

Na península Ibérica, os mouros introduzem o plantio da cana-de-açúcar e o fabrico do produto, aproximadamente, no meado do século XII, mesma época que haviam introduzido em Marrocos. As principais regiões produtoras de açúcar estão reino de Granada, Salobreña, Almuñecar e a oeste Modril. O açúcar produzido na Granada é exportado exclusivamente para Constantinopla, na segunda metade do século XV. No levante peninsular, na região da valenciana existiam também plantio de canade-açúcar e por lá também os engenhos para produção do açúcar, na qual a posse estaria sobre a administração alemã, onde em 1477 são vendidos os engenhos que ali possuem $^{68}$. Parece-me que nesta época, os engenhos da região do Atlântico entravam em grande ascensão, principalmente na ilha da Madeira, que havia sido descoberto em primeiro lugar e experimentado tal prática. Além da ilha Madeira, os portugueses haviam também experimentado a produção da cana sacarina, antes de 1404. Talvez isso servisse de um grande impulso para que efetivasse a produção, posteriormente na dita ilha. Como afirma Godinho:

Duarte de Leite comenta com razão: que naquelas terras havia, pois canaviais antes de 1404 , e é de crer que não fossem os únicos no Algarves, nem privilegio da coroa. Cinco anos depois, uma horta também da coroa, em Loulé, é aforada por 5.000 libras anualmente a Joham de Palma, Nicolau de Palma e ao filho do primeiro, afim que nele plantarem canas-de-açúcar ${ }^{69}$.

Se Algarves e nenhuma outra região de Portugal houvessem experimentado a produção açucareira, como mostra o Godinho, talvez a sua prática nas ilhas do Atlântico e posteriormente no Brasil, seria mais difícil e até impraticável. São vários os indicativos que reforçam a ideia de que em Portugal já havia a cana-de-açúcar. Em 1403 finou-se um Afonso Anes que além de exercer o cargo de escrivão e guardador dos navios que vem em Lisboa, era também açucareiro. Em 1931 uma das testemunhas de ato tabeliónico passado em Lisboa é um Gomes Loureiro "açucareiro Del Rei, morador

\footnotetext{
${ }^{68}$ GODINHO, Vitoriano Magalhães. Os descobrimentos e a economia mundial. Lisboa: Editorial Presença, 1963, v. 4. p. 72.

${ }^{69}$ Certamente em Portugal, já havia o plantio de cana, muito antes que na Madeira. A produção da Madeira, provavelmente seria uma consequência do que já havia feito na metrópole. As condições oferecidas na ilha facilitaram o processo (na carta 8-v1049, em Silva Marques, Vol. I, p. 121) isso fica claro. A região que mais se destacou nesse processo é a de Algarves, que nesta época já contava com muitos plantios bem como os engenhos para produção do açúcar. Ver: GODINHO, Vitoriano Magalhães. Os descobrimentos e a economia mundial. Lisboa: Editorial Presença, 1963. v. 4. p. 73.
} 
da dita cidade". Amorim Pereira, sem excluir a possibilidade de tratar de ofício da casa do Rei, estaria também ligado ao fornecimento da especiaria; Duarte de Leite chamou a atenção para festejos que infante D. Henrique ofereceu aos irmãos no natal de 1414 em Viseu, e onde se comemoram "toda lãs viandas d 'açúcar e conservas que se puderam achar no regno", podendo ter como certo que boa parte do açúcar era de origem nacional. Em 1451, viajantes alemães viram canaviais de açúcar em muitos lugares do reino, em especial nos campos de Coimbra, ao lado dos trigais e vinhas, sublinhando ainda que tudo se tratasse de uma riqueza do reino. Também de acordo com o mesmo autor, era o infante D. Pedro quem mandava plantar os canaviais. Salienta que isso ocorreria desde que os portugueses estavam em contato com a zona marroquina de cultura e fabrico, em vales de bulhões em 1447, se não antes, tratavam de relações comerciais no Suz, através da Messa ${ }^{70}$. Apesar do Atlântico apresentar-se favorável para a produção do açúcar, nem todas as ilhas ali existente tiveram a mesma sorte. Na época da descoberta de São Tomé, haviam descoberto nessa mesma época outras ilhas com característica parecidas, porém o que mais ali interessou a coroa e que encontrou sucesso foi a ilha de São Tomé. O conjunto vulcânico que inclui São Tomé, também faz parte as ilhas de Ano Bom, Príncipe e Fernando Pó. Este conjunto apresentou-se para os seus descobridores como muito original ao seu relevo, clima e vegetação em virtude as situações equatorial das ilhas, como uma grande novidade para quem conhecia somente as ilhas da sub-região do Atlântico ${ }^{71}$. Predomínio de condições ambientais quentes e úmidas, boa parte no ano com muita chuva, curtos período seco e ventoso, uma vegetação luxuriosa e abundância de florestas são as características marcantes, um diferencial dentro do perfil de algumas ilhas existentes na região. Tenreiro, mostra-nos que a razão da diversidade dentro de uma unidade que resultou condições naturais comum tem de explicar-se também por um processo colonizador se ter processado para algumas daquelas ilhas em épocas diferentes e em ritmos diferentes. O que ocorre foi que muitas dessas ilhas foram menos aproveitadas se comparadas com a ilha de São Tomé, embora descobertas na mesma época, para mesma finalidade e com características muito parecidas $^{72}$. Assim destaca Tenreiro:

Enquanto São Tomé, poucos anos após o descobrimento, ocupada (1486) e as ilhas do Príncipe e Ano Bom se iriam logo desenvolver a

\footnotetext{
${ }^{70}$ GODINHO, Vitoriano Magalhães. Os descobrimentos e a economia mundial. Lisboa: Editorial Presença, 1963, v. 4. p. 73.

${ }^{71}$ TENREIRO, Francisco. A Ilha de São Tomé. Lisboa: Junta de Investigações do Ultramar, 1961. p. 13.

72 TENREIRO, Francisco. A Ilha de São Tomé. Lisboa: Junta de Investigações do Ultramar, 1961. p. 13.
} 
sua sombra (iniciam as colonizações em 1502 e 1503 respectivamente), a ilha de Fernando Pó só no século XVIII, a partir de 1778, seria eficazmente ocupada, (...). Foi à cultura de cana-deaçúcar o elemento catalisador do povoamento, feito essencialmente com europeus de Portugal e da ilha da Madeira com escravos negros trazidos do litoral africano. São Tomé e Príncipe, as ilhas mais chegadas, passariam pelas mesmas vicissitudes históricas, econômicas e sociais, enquanto que o Ano Bom, ocupada cedo e colonizada inicialmente por gentes de São Tomé, seria também pelas suas fracas aptidões naturais, também cedo abandonada. Fernando Pó é ilha esquecida até a tarde..., depois deter sido cedida à Espanha, Fernando pó terá uma ocupação efetiva; mesmo assim, só virá a desenvolver-se com introdução do cacaueiro, na segunda metade do século XVIII ${ }^{73}$.

Após o desenvolvimento do comércio na ilha da Madeira, em seguida viria o desenvolvimento da ilha de São Tomé, em termos de volume da produção. Algumas ilhas como conjunto de Cabo Verde, nem representou tanto em volume de produção açucareira como Madeira e São Tomé, e posteriormente o Brasil. Outras não chegaram a experimentar tais processos, como é o caso do Ano Bom e Fernando Pó, já mencionado acima. O impulso da produção açucareira na ilha da Madeira é dado por, em parte, da guerra de corso contra os mouros e dos assaltos às Canárias, donde já no século XIV canaviais e engenhos do levante espanhol se tinham fornecido mão de obra $^{74}$.

As ilhas do Atlântico, quando descobertas foram delegadas aos homens nobres as tarefas de organizar e administrá-las, assim foram criadas as capitanias de Machico para Tristão Vaz Teixeira em 1440, de Porto Santo para Bartolomeu Perestrelo em1444 e do Funchal para João Gonçalves Zarco em 1450. A estes capitães Dom Henrique entrega a jurisdição do cível e do crime, com as limitações que a ele mesmo eram postas. Esses capitães recebiam a décima parte das rendas do senhor, do que produziam e tinham autoridade também para distribuição de terras em sesmaria, ou a retirar a aos que não as tivessem efetivamente cultivados, nos prazos estipulados. Nas terras novas, os colonos introduziam cultivos a que estavam habituados e que faziam mais falta à sua alimentação $^{75}$. Essa tarefa, a princípio, não pareceu tão fácil, primeiro cortavam as árvores que cobriam a ilha, depois faziam construções e introduziam os produtos. Nesta época havia tantos matos e rochas várias, enormes montanhas e grotas, que afirmavam

\footnotetext{
73 TENREIRO, Francisco. A Ilha de São Tomé. Lisboa: Junta de Investigações do Ultramar, 1961. p. 1617.

74 GODINHO, Vitoriano Magalhães. Os descobrimentos e a economia mundial. Lisboa: Editorial Presença, 1963. v. 4. p. 73.

${ }_{75}$ MAGALHÃES, Joaquim Romero. O açúcar nas ilhas portuguesas do Atlântico séculos XV e XVI. Varia Historia, Belo Horizonte, v. 25, n. 41, p. 151-175, 2009. p. 153.
} 
todos que, em cada dez partes da ilha, aproveitam menos de duas, porque a maior parte dela são serranias, terras dependuradas, rochas, grotas e ladeiras, e não há terra chã, senão a bocados, mas esses são tais, que valem mais que outro tamanho ouro; e, geralmente, não tem preço à substância, que tem todas as coisas, que esta ilha de si está produzindo, quer por natureza, quer com arte ${ }^{76}$.

A Ilha da Madeira se mostrou muito favorável devido ao seu clima e ao solo para o plantio e a produção da cana-de-açúcar, 'sendo estas terras tão férteis que em cima de qualquer rocha que cobrir dois ou três dedos de terra e que tenha água logo se faz cana de 18 palmos de açúcar." Para Magalhães ${ }^{77}$, a iniciativa vinha do infante D. Henrique, que teria ordenado que introduzissem canaviais e a partir disso, novas plantas das melhores qualidades teriam sido trazidas de Sicília e de Valência, que rapidamente se desenvolveram, sobretudo no sul da ilha, onde demonstrava uma situação mais apropriada. Para essas jornadas, exigiu muito trabalho, pois nem sempre por essas regiões abundava a água e havia necessidade, na maioria das vezes, fazê-la chegar de onde era mais abundante, levando-a para região sul, onde se cultivava a cana. Assim se conjugava a necessidade de água para a rega com a temperatura-ambiente obtendo-se o desejado gênero. $\mathrm{O}$ açúcar desde cedo, também começa a ser usado para fazer confeitos e outros mimos de conservas doces, para isso, necessitava-se muito da água. A água, de alguma forma, constituiu algum obstáculo para a produção açucareira na ilha da Madeira, bem diferente do que ocorreria na ilha de São Tomé, onde havia riachos por todos os lados.

Para dinâmica produtiva deste precioso produto na Ilha da Madeira, segundo Magalhães ${ }^{78}$, usavam-se as alçapremas, na qual a cana era moída a braços. Depois de alguns anos, ou seja, em 1452, ao senhor da ilha, Infante D. Henrique, se deve o investimento num engenho d'água para se nele fazer açúcar e em troca, o senhorio receberia um terço do produto da laboração. Nesse novo equipamento, se moeria toda a cana, reservando-se autorizar a feitura de outros, se lhe aprouvesse e se revelasse indispensável. Parece-me que o açúcar produzido na Madeira era de altíssima qualidade, muito que os consumiam, logo queriam comercializá-lo. Um testemunho auferido por

\footnotetext{
76 FRUTUOSO, Gaspar. Saudades da terra: livro II. Ponta Delgada: Instituto Cultural de Ponta Delgada, 1998, p. 138-139.

${ }^{77}$ MAGALHÃES, Joaquim Romero. O açúcar nas ilhas portuguesas do Atlântico séculos XV e XVI. Varia Historia, Belo Horizonte, v. 25, n. 41, p. 151-175, 2009. p.154.

${ }^{78}$ Ibid., p. 155.
} 
Magalhães ${ }^{79}$, conta que veneziano Luís de Cadamosto vindo da sua pátria e chegado numa galé ao Cabo de São Vicente, no Algarves, servidores do infante vieram "com algumas amostras de açúcar da ilha da Madeira, e de sangue de drago e outras boas coisas também trazidas dos lugares e das ilhas do sobredito senhor". O açúcar se expandiu rapidamente, por um lado pela sua valorização e por outro, o produto começa a ser mais conhecido. Assim, a sua produção mal começara e as mercadorias já eram requisitadas em quase todos os mercados da Europa. No início a produção, não seria bastante para suprir o mercado consumidor, não obstante se revelava interessante. Bons resultados deste processo começaram a ser revelado com incentivo e o aumento do cultivo na ilha. Em 1456 já havia grandes sinais do açúcar da ilha da Madeira na alfândega inglesa de Bristol. Se não foi lento, o povoamento da Madeira, também não terá sido muito célere. Devido à demanda do produto que resultou na necessidade de aumento da produção, outras necessidades se fez sentir, como a ausência de mão de obra. Para isso, buscou-se alternativa nas Canárias e nas regiões africanas, especificamente a região de São Jorge de Minas, para fornecer escravos para este trabalho. Mão de obra de Guanches canarinos teria nessa atividade um estímulo determinante $^{80}$. Assim a cana-de-açúcar se liga cedo com o trabalho cativos, embora, como já foi observado, na Madeira se fazia uma agricultura de plantação de pequenas propriedades, a necessidade de uma avultosa força de trabalho, não se fazia com muita necessidade. Essas pequenas e médias propriedades eram as áreas que cada lavrador ou grupo de lavradores cultivavam.

O açúcar começou a ganhar espaço no mercado internacional de forma crescente, e este produto que era considerado uma especiaria rara, começa a se mostrar muito mais rentável do que o trigo, devido à flexibilidade do preço e a nova dinâmica do mercado. Por ali, as alçapremas e aos engenhos d'água juntavam-se aos trapiches de bestas e um moinhos de tração animal. Houve uma melhora nos equipamentos que permitiu o crescimento da produção e o seu lançamento no mercado internacional, permitindo a concorrência com o açúcar produzido na Sicília e no Mediterrâneo oriental. O crescimento da produção açucareira foi surpreendente na ilha da Madeira, ainda em 1470 se estimava que a produção girasse em torno de 20.000 arrobas e nos finais do século atingiria as 105.000 arrobas, ou seja, neste período de tempo a produção

\footnotetext{
${ }^{79}$ Ibid., p. 155.

${ }^{80}$ MAGALHÃES, Joaquim Romero. O açúcar nas ilhas portuguesas do Atlântico séculos XV e XVI. Varia Historia, Belo Horizonte, v. 25, n. 41, p. 151-175, 2009. p.155.
} 
mais do que quintuplicou, admitindo como máxima para exportação em torno de 120 mil arrobas.

O êxito inicial auxilia no alargamento das áreas ocupadas por canaviais. O que tinha por limites as condições naturais dos solos e a sua situação na proximidade com as águas. Águas para irrigação, quando necessário, águas para a instalação e funcionamento dos engenhos para a transformação da cana. Muitos mercadores levavam o açúcar para vender no Mediterrâneo e, sobretudo no norte flamengo, fazendo concorrência aos produtores instalados em outras áreas. Os preços depreciavam-se com a chegada deste novo fornecedor. Os capitalistas que financiavam a expansão dos canaviais, assim deixariam de comprar o açúcar antes produzido em outras regiões, o que desestabilizava o mercado fazendo com que houvesse a baixa nos preços praticados neste $_{\text {comércio }}{ }^{81}$. Para restabelecer o mercado, o infante D. Fernando, em 1469, criou um monopólio de mercadores de Lisboa que comprasse toda a produção açucareira, garantindo a manutenção dos preços. Por 1504 a produção teria atingido as 182.000 arrobas, subindo para 230.000 em 1506, desta forma, duplicando em dois anos. Mas depois começa a baixar, atingindo apenas 115.000 arrobas em 1518. Pior será daí em diante. Das 106.000 em 1521, e decrescendo para 46.0000 arrobas em $1537^{82}$.

A descoberta no Atlântico continuaria e por volta de 1460-1462 mais ilhas foram encontradas na costa africana da contra Guiné: Ilhas de Cabo Verde. As descobertas deveram-se a Diogo Gomes e António da Noli, das cinco primeiras ilhas, entre elas: Santiago, Fogo, Maio, Boa Vista e Sal e as restantes ao Diogo Afonso: São Nicolau, Santa Luzia, São Vicente, Santo Antão (posteriormente chamada da ilha da Brava). Recebeu-as em senhorio, por doação da Coroa, o infante D. Fernando, irmão do rei D. Afonso V e filho adotivo do infante D. Henrique, já senhor da Madeira e de algumas das ilhas dos Açores. Que, como os outros infantes donatários, também se limitaram a administrá-las de longe. Tendo continuado a delegar funções de administração direta à capitães escolhidos por ele. Com as limitações que já se tinham estabelecido para os capitães-donatários da Madeira e dos Açores $^{83}$ não tardou muito para começar o propósito da colonização. Em 1462 na ilha de Santiago, houve incentivo para lá se

\footnotetext{
${ }^{81}$ PEREIRA, Fernando Jasmins. Estudos sobre história da Madeira. Funchal: C.E.H.A., 1991. p. 96.

${ }^{82}$ MAGALHÃES, Joaquim Romero. O açúcar nas ilhas portuguesas do Atlântico séculos XV e XVI. Varia Historia, Belo Horizonte, v. 25, n. 41, p. 151-175, 2009. p.160.

${ }^{83}$ As viagens das descobertas portuguesas não pararam na ilha da Madeira e em 1460-1462 foram encontradas novas ilhas desabitadas. Ver: MAGALHÃES, Joaquim Romero. O açúcar nas ilhas portuguesas do Atlântico séculos XV e XVI. Varia Historia, Belo Horizonte, v. 25, n. 41, p. 151-175, 2009. p.165.
} 
estabelecer os colonos que quisessem trabalhar com a costumada distribuição de sistema de sesmarias, e os indicados eram os genoveses e os portugueses. Contudo, no início foi difícil encontrar colonos dispostos a irem. Devido à distância e apesar das isenções fiscais que o monarca concedeu, os moradores ficavam livres de pagamento de direitos alfandegários na introdução no reino de produtos do trato com as costas africanas fronteiras era difícil conseguir pessoas para afixação no local. O que acabou por significar fazer do arquipélago um entreposto no trato de escravos africanos, que era o que de mais comum e de maior valor os moradores traziam dos rios da Guiné.

Nesta região da Guiné provinham muitos alimentos, como: milho, arroz, marfim e cera, parte deste para comércio e outra parte seria usado na alimentação dos escravos.

Sem dúvidas, nos primeiros anos de colonização, as ilhas receberam degredados como povoadores que serviriam como parte da manutenção da empresa agrícola ali instalada. Nem todas as ilhas descobertas no Atlântico se mostraram favoráveis ao cultivo de cana-de-açúcar, sendo que algumas apresentavam regiões áridas, com difíceis condições para a agricultura, cujo aproveitamento das terras ocorreu de forma lenta. Apesar disso logo em 1490 se assinala a existência de cana-de-açúcar na ilha de Santiago. Começa a colonização do arquipélago precisamente pela ilha de Santiago, a maior do conjunto destas ilhas, de razoáveis ancoradouros e com alguma água. A que se reconhece alguma fertilidade. Esta ilha dá todas as frutas de Portugal que se nela plantavam, figos, uvas, melões, açúcares, e todas as outras frutas por todo o ano. No entanto, não produzia trigo nem cevada. As temperaturas na ilha de Cabo Verde pareciam propícias, e isso de alguma forma veio a facilitar a introdução da cana. Não obstante, o fator climático não pareceu suficiente para instalação de todo o processo, e se ocorresse, não poderiam multiplicar explorações extensivas, como aconteceu na Madeira, pois a cana-de-açúcar exige muita água e o seu plantio, normalmente é feito próximo as ribeiras, e nessas novas ilhas a água era muito escassa. Carvalho mostra que: "frutos não se dão nesta terra senão for regado e as boas terras de aluvião também não abundavam, limitando-se a alguns vales ou junto da costa". Os canaviais instalavam-se próximos de outros cultivos, de árvores de frutos ou de legumes. E até mesmo de criações de gado. A policultura prevalece. Tirando em Santiago, os produtos agrícolas nas ilhas são poucos e difíceis de se obter. Salvo a pecuária que, para as ilhas não ocupadas por humanos, vinha a contento, de onde algum rendimento se podia obter ${ }^{84}$.

\footnotetext{
${ }^{84}$ CARVALHO, Joaquim Barradas de. Esmeraldo de situ orbis de Duarte Pacheco Pereira. Lisboa: Fundação Calouste Gulbenkian, 1991. p. 610.
} 
O arquipélago de Cabo Verde é composto por ilhas muito secas e a maioria das vezes, chove somente três meses durante o ano, sendo estação seca de nove meses. Quando descobertos, por lá havia muitos gados e isso seria uma das características dessas ilhas. Salvo na ilha de Santiago, que possui um clima mais apropriado para canade-açúcar, nas outras não poderem ser instalas os canaviais. O açúcar não teve grande sucesso nas ilhas de Cabo Verde, como um todo, pois não era uma produção que tivesse uma expressão que se destacasse. Mas nem por isso deixava de se tentar. Por 1540, se sabe que em Santiago dentro da fazenda da Trindade estão dois engenhos de trapiches de fazer açúcares, com todo o cobre e mais utensílios necessárias aos dos engenhos. Em Santa Cruz, outra fazenda do mesmo senhorio, se escreve que havia um engenho trapiche de açúcar ${ }^{85}$. Desta, seria uma demonstração de que na Ilha de Cabo Verde, não se processou muitas fazendas do açúcar, o que significa dizer que a produção fosse feita em um volume muito reduzido.

Por motivos vários, o atrativo comercial desta ilha, em particular, Santiago residiu desde cedo nos escravos, que em grandes números aí eram embarcados com destino à Europa ou à América. Poucos engenhos se poderiam estabelecer nessa ilha, que poucas eram as águas correntes que podiam ser aproveitadas para isso. As pequenas produções pisariam as canas em pilões, trabalho penoso, manual. Pequenas áreas de cultivo de cana que teriam persistido resistidos às longas estiagens que afetam duramente as ilhas. Mas obtinham-se algumas quantidades de açúcar, embora o ignore o piloto anônimo que cerca de 1540-1541 aí se detém contando dos produtos da terra. $\mathrm{O}$ que significa que não dava nas vistas, mesmo a um visitante curioso dos recursos das ilhas. Em finais do século Gaspar Frutuoso assinala que a "ilha de Santiago dá muito açúcar, e fazem-se nela muito boas conservas, ainda que nada disto chega ao da ilha da Madeira. Tem de ser considerado exagero de quem ouviu contar sem ter observado. Porque isto se escreve num tempo em que o açúcar da Madeira já estava em perda e a ser substituído pelo que vinha do Brasil. Embora continuando a ser cultivada, desde cedo se constatou que a cana doce apenas dava para algum abastecimento local em açúcar e em aguardente, não sendo suficiente para exportação. Abastecimento local, pois, e para o trato nos rios da Guiné onde a aguardente era apreciada e se tornaria valiosa para a troca de mercadorias. Na maioria das ilhas de Cabo Verde a secura e a

85 CARREIRA, António. Estudos de economia cabo-verdiana. Lisboa: Imprensa Nacional-Casa da Moeda, 1981. p. 239. 
aridez do clima não podiam ser vencidas. Os três meses de chuvas por ano, e por vezes escassas, para mais não dariam. E esses eram os principais obstáculos, porque não faltaria mão de obra servil, proveniente da costa africana fronteira para os trabalhos da plantação e mesmo da transformação. E o resultado muito insignificante e de pequena produtividade, ficou evidente logo no princípio do século XVI em que 70.000 arrobas são produzidas na Madeira em 1508 e 20.000 nos Açores no ano 1509, em Cabo Verde, não chegaria na faixa de 4.000 arrobas, entre 1508 a 1509. Essas ilhas foram basicamente, suportes e os símbolos da hegemonia peninsular no Atlântico. A disputa pela riqueza no oceano Atlântico trouxe para esta região muitos piratas e principalmente os corsários ingleses, franceses e holandeses, ávidos pelas riquezas em circulação. Uma das maiores preocupações das coroas nessas regiões peninsulares foi a defesa das embarcações para que não fossem invadidas pelos corsários europeus. Esta defesa nem sempre encontrava solidez e eficácia, pois internamente, dentro do sistema governativo das ditas ilhas, havia muitas das vezes grandes disputas pelo poder por parte das classes eclesiásticas, de senhores das terras e até mesmo dos comerciantes, como ocorrera em São Tomé. Essas instabilidades ou fragilidades internas acabavam desestabilizando a estrutura interna para a defesa como um todo.

Para Lains e Silva, a história do açúcar no século XVI se caracteriza resultante de abundância de metais preciosos e do aumento geral do consumo de todos os artigos. Para o mesmo autor, na década de 1511 a 1520 duplica o preço do açúcar, o qual continua a aumentar até meados do século $\mathrm{XVII}^{86}$. Lembrando que a coroa portuguesa procurava um produto com preço atrativo e que gerasse lucro de forma facilitada. Por outro lado, a indústria açucareira foi destruída na Síria e no Egito, que os árabes conquistaram em 1517, o que veio a impulsionar a produção do mesmo em outras regiões recém-descobertas, em particular, nas ilhas do Atlântico. Na ilha da Madeira a produção chegou 300.000 arrobas, nos meados o século XVI e no início do século seguinte, a mesma produção atinge, aproximadamente 400.000 arrobas ${ }^{87}$.

Provavelmente, esses dois fatores (destruição do açúcar na Síria e no Egito, bem como aumento o preço do açúcar), tiveram grande peso na expansão deste produto para outras regiões e principalmente para no mundo Atlântico, no século XVI e mediante tais condições, veio a favorecer o mercado consumidor, em grande medida, nas regiões da

\footnotetext{
${ }^{86}$ LAINS E SILVA, Hélder. São Tomé e Príncipe e a cultura do café. Lisboa: Junta de Investigações de Ultramar, 1958. p. 80

${ }^{87}$ LAINS E SILVA, Hélder. São Tomé e Príncipe e a cultura do café. Lisboa: Junta de Investigações de Ultramar, 1958. p. 81.
} 
Grã-Bretanha, Flandres e portos de Itália, o que fez aumentar o fluxo de mão de obra escrava nas regiões produtoras do produto.

A trajetória do açúcar pós-mediterrâneo começa na ilha da Madeira passa pelos Açores, Cabo Verde, São Tomé, Brasil e Ilhas Caribenhas. Em São Tomé e Príncipe, a cana-de-açúcar começa a ser produzida com a chegada dos portugueses, por volta de 1481 e no terceiro quartel do século seguinte, se desenvolve consideravelmente.

O tráfico do açúcar estava entrelaçado com as principais rotas que uniam o Brasil a São Tomé, e São Tomé a Lisboa, nas quais carregava consigo todos outros comércios que para o período se mostravam rentáveis para os colonos, sobretudo do trafico de escravos e algumas especiarias, como: pimenta, tinturas, peles, cereais, etc., Assim do entreposto do Tejo os navios partiam carregados de mercadorias para Merselha e Genova por um lado, para lá Rochelle, Nantes, Ruão, Londres, Amsterdã e Hamburgo, por outro lado, e pelos caminhos de terra era abastecida a Espanha. Navios de Viana ou do Porto iam para São Tomé carregar açúcar para vender nos países baixos e voltando para Porto de origem carregados de panos de algodão ${ }^{88}$. A descoberta do Atlântico foi um grande alívio para economia europeia e em particular, para Portugal que se encontrava antes de tais descobertas, em uma situação econômica muito fragilizada. Até a descoberta do Atlântico, a maior preocupação dos portugueses seria encontrar um produto que suprisse a escassez de cereais que se fazia presente no reino.

\section{4 - Gênese do açúcar em São Tomé.}

Existem duas questões intrigantes sobre a ocupação das ilhas que se pretende discutir neste capítulo e ambas estão relacionadas ao início do processo de produção açucareira. O primeiro seria o ano no qual se deu início a produção açucareira e o segundo como o processo de produção ocorreu. Em relação ao início da produção em São Tomé, parece haver certa contradição, ou uma incerteza, como já foi apontada na introdução desse trabalho. A data da introdução do açúcar em São Tomé parece ser incerta, para muitos autores o produto começou a ser produzido no momento após a descoberta das ilhas e enfatizam que a produção se deu somente no início do século seguinte.

${ }^{88}$ GODINHO, Vitorino Magalhães. Portugal, as frotas do açúcar e as frotas de ouro (1670 - 1770). Revista de História, São Paulo, v.7, n. 15, p. 69-88, 1953. p. 72. 
Para Lains e Silva ${ }^{89}$, nos princípios do século XVI não existia ainda a indústria açucareira nestas ilhas, embora houvesse já grandes canaviais. Em 1517 existiam apenas dois engenhos e a produção de açúcar se verificou por volta de 1529, gerava somente em torno de 5.000 arrobas, isso pelo fato do rei do Portugal ser simultaneamente o senhor do engenho e o mercador, assim priorizando mais os comércios ${ }^{90}$. Devido algumas dificuldades encontradas, a coroa começou a abandonar algumas atividades econômicas e foi priorizando outras só assim a produção açucareira começou a se expandir, deste modo, passando a ser exploradas por contratadores ${ }^{91}$. A partir desse momento, o processo de produção foi rápido, ao mesmo tempo em que aumenta o comércio com os Flandres. Em 1531 a renda de São Tomé provinha principalmente do açúcar exportado. Em 1540 mercadores portugueses e espanhóis fretavam navios para o transporte do açúcar de São Tomé para portos da Europa.

Para Robert Garfield ${ }^{92}$, o açúcar já era produzido numa escala relativamente pequena no ano 1496, momento após a descoberta da ilha. Para se ter uma ideia, em contraste com a produção da ilha da Madeira, que havia em 1450, produzido 300.000 arrobas por ano, em 1496 esta mesma produção cairia para 120.000, em função da produção da ilha de São Tomé. Isso leva a crer, nessa analogia, que o açúcar de São Tomé supriria a demanda internacional, nesta época em 180.000 arrobas, o que significaria um incremento na produção nesta região do Atlântico. Um aspecto importante de salientar é que a produção da ilha da Madeira resultava de grande número de pequenos proprietários de terras em pequenas propriedades produtoras de açúcar enquanto que na ilha de São Tomé, o processo era contrário, havia poucos proprietários para grandes plantações e na produção, o que significa que nas ilhas de São Tomé houve uma produção muito maior. À medida que a produção na ilha São Tomé ia aumentando, o da ilha da Madeira ia declinado. Em 1530 quando o açúcar de São Tomé começou a ter grande impacto no mercado internacional fez declinar a produção da Madeira em

\footnotetext{
${ }^{89}$ LAINS E SILVA, Hélder. São Tomé e Príncipe e a cultura do café. Lisboa: Junta de Investigações de Ultramar, 1958.

${ }^{90}$ LAINS E SILVA, Hélder. São Tomé e Príncipe e a cultura do café. Lisboa: Junta de Investigações de Ultramar, 1958. p. 83.

${ }^{91}$ LAINS E SILVA, Hélder. São Tomé e Príncipe e a cultura do café. Lisboa: Junta de Investigações de Ultramar, 1958. p. 84.

${ }^{92}$ By about 1450, some 300.000 arrobas per year were produced in Madeira, and the growing of sugar was regulated lest of the market collapse. By 1496, when São Tomé had just been settled, production was down to 120.000 arrobas, though the number of sugar-mill was some 120, indicating the crop was produced mainly a great number of small planters, in contrast to São Tomé's concentrated productions a mill number of great land-owners. Ver: GARFIELD, Robert. A history of São Tomé Island, 1470-1655: the key to Guinea. São Francisco: Mellen Research University Press, 1992. p. 64.
} 
40.000 arrobas, considerando que em 1520, dez anos antes, a produção da Madeira era em torno de 54.000 arrobas e em sete anos depois a produção desta declinaria para 25.000 arrobas. O que valorizava o açúcar da ilha da Madeira seria a qualidade, pois se supõe que o mesmo tivesse uma melhor qualidade se comparada à produção de São Tomé, o que faria com que o preço praticado em São Tomé fosse menor do que o preço praticado na ilha da Madeira. Vejamos, se vieram os mestres, especialistas do açúcar madeirenses e genoveses para produzirem açúcar em São Tomé, porque o produto teria uma menor qualidade? Essa questão me parece muito pertinente e merece uma reflexão. Havia grandes incentivos por parte da coroa, por outro lado, havia uma demanda crescente pelo açúcar de São Tomé. Anos após a descoberta de São Tomé, por ali plantavam-se áreas vastas de cana-de-açúcar, bem como grande incentivo para instalação de novos engenhos ${ }^{93}$.

Loureiro $^{94}$ destaca que o açúcar de São Tomé não é muito duro, nem muito branco e para fazer um açúcar mais branco e mais duro, vinham muitos mestres da ilha da Madeira. Salienta que devido aspecto muito gorduroso do terreno, o sucesso não seria alcançado. Outro ponto seriam os ares que pairam sobre a dita ilha, não enxugam os açucares devidamente quando as mesmas são tiradas das formas, porque o sol, onde quer que esteja não é quente e seco como na Vila de Conde, mas sobre a ilha é quente e úmido, exceto os meses de junho, julho e agosto, em que os ventos, que vem da parte da Etiópia, são enxutos e frescos. Eu creio que este argumento não seria suficiente para que o açúcar feito em São Tomé fosse de péssima qualidade, ainda que o tempo fosse um obstáculo, existem três meses que poderiam ser compensado e aperfeiçoar tais produções. Por outro lado, o mesmo autor enfatiza que quando em situação da umidade do ar, os mestres do açúcar imaginaram um método de enxugá-lo que consistia em fazer um coberto alto de tábuas, como nós os estendedouros todo fechado por cima e dos lados, sem janela alguma. Por elas vão estendendo tábuas, nas quais colocam pães de açúcar e embaixo do dito estrado estão algumas madeiras secas, de árvores grossas. Deste modo enxugam os açucares, como numa estufa, conservando em lugares todo

\footnotetext{
${ }^{93}$ Os oficiais obtiveram autorização régia para fazer sua roça e fazenda grandes plantações de cana sacarina e implantar nela engenhos de moer açúcar e assim como agora fazem os moradores da dita Ilha. Ver: Arquivo Nacional da Torre de Tombo (ANTT). Cf. Chancelaria de D. João III, Doações, Livro 46 fls. 204.

${ }^{94}$ LOUREIRO, Rui. Navegação de Lisboa à Ilha de São Tomé: escrita por um piloto português. Lisboa: Grupo de trabalho de ministérios da educação para comemorações dos descobrimentos portugueses, 1989. p. 27.
} 
fechado com tábuas, de modo que os ares não entram. E assim que chegam os navios, logo os vendem, porque se quisessem conservá-los dois ou três anos se tornaria líquido ${ }^{95}$. Como foi observado acima, houve um método de conservação muito eficiente para aquela época, que os açucares manteriam sua qualidade por um determinado tempo até a sua venda. Talvez o que possa ter acontecido, é que alguns produtores, naquela época tenham deixado o açúcar armazenado mais de três anos, o que veio a deteriorar o produto, assim impossibilitando a sua venda. Isso provavelmente levou muitos comerciantes que viessem a comprar o açúcar, a supor que produzissem um produto de péssima qualidade. Em lugar algum, há açúcar que aguente três anos sem que não se deteriore.

De São Tomé se levou muitos escravos para as primeiras plantações de cana-deaçúcar feitas no Brasil, provavelmente aproveitaram também seus mestres. Não existe até o momento documentação que comprove que os mestres fossem somente da Ilha da Madeira ou que simplesmente fossem de São Tomé, mas acredito que uma vez que São Tomé sucedeu Madeira na produção deste bem, provavelmente isso se faria também quando da produção de brasileira. Alguns autores alegam que os mestres açucareiros do Brasil vieram da ilha da Madeira e outros afirmam que os mesmos vieram de São Tomé. Não se sabe, mas tudo leva a crer que tenham sido levados de São Tomé. Desta forma, se experiência para o Brasil fosse trazida de São Tomé, porque não houve uma péssima experiência no Brasil e por que o produto não foi de uma péssima qualidade? Mas a frente, esta questão será mais discutida, mas por agora, deixo como uma reflexão.

O surto açucareiro em São Tomé contou com a ida de homens da ilha da Madeira, trazendo consigo todas as experiências na fabricação deste produto. Muito comum era a ida de navios de Lisboa para carregar açúcares de São Tomé, porque a principal ocupação dos habitantes era fabricar açúcar e vende-los aos navios que todos os anos o iam buscar. De 1535 a 1548, o principal mercado de açúcar de São Tomé, continuava a ser o flamengo, na qual 112 navios entram com açúcar no porto de Antuérpia, quase exclusivamente de São Tomé ${ }^{96}$. Segundo Godinho ${ }^{97}$, em 1522 os

\footnotetext{
${ }^{95}$ LOUREIRO, Rui. Navegação de Lisboa à Ilha de São Tomé: escrita por um piloto português. Lisboa: Grupo de trabalho de ministérios da educação para comemorações dos descobrimentos portugueses, 1989. p. 28.

${ }^{96}$ No início do século XVI, São Tomé poderia ser considerado o principal produtor de açúcar e Antuérpia o principal mercado consumidor. A maioria dos navios que entravam nesta cidade eram de São Tomé, carregados de açúcar e alguns outros artigos. Se o produto feito nesta ilha fosse de péssima qualidade, como alguns autores apontam, seus produtores não insistiriam muito tempo produzindo neste local. Ver: GODINHO, Vitorino Magalhães. Os descobrimentos e a economia mundial. Lisboa: Editorial Presença, 1963. v. 4. p. 95.
} 
produtores de açúcar na ilha da Madeira temiam a concorrência desta nova produção, vinda de São Tomé, pois nesta época viu-se a sua produção crescer de forma vertical. Em 1525 a produção deveria atingir as 111 mil arrobas ou talvez mais e o principal mercado era Flandres.

O segundo aspecto, seria que o processo da produção açucareira, é composto por várias etapas até que chegue a fase produtiva. Como observa Alberto Vieira ${ }^{98}$, o processo começa com o plantio das canas, acompanhamento constante, mondar, esfolhar, combater as pragas e efeitos nefastos dos animais, cortar e, depois, conduzir ao engenho onde se moía e extraía o suco daí resultante para se fazer o açúcar. Este processo não seria uma tarefa que ocorria do imediato, muitas das vezes, a cana-deaçúcar era introduzida em determinado território, passado muito tempo, só depois seria transformada em açúcar.

Além disso, antes era necessário encontrar um terreno que se adequasse ao plantio da cana-de-açúcar e depois realizar a derrubada e queimada de arvores por lá existentes. A maturação do processo faz-se em cinco ou em seis meses, e o clima não impede que se plante a qualquer mês e findo esse prazo sejam cortadas as canas. Por outro lado teria que se levar em consideração as regiões onde possuíssem riachos bem como as mão de obra disponível para trabalho. A produção era feita principalmente nos engenhos d'água, bem como em trapiches de cavalos, e nos lugares onde não possuíam água em abundância, usava-se braços escravos ${ }^{99}$. A tecnologia usada na produção do açúcar é de fundamental importância para o processo como um todo. O fabrico do açúcar está limitado pela situação e o ciclo vegetativo da planta. A colheita da cana-deaçúcar está relacionada ao período útil de vida em que a percentagem de sacarose estaria mais elevada. Assim, a cana estaria pronta para ser colhida e a partir dali, um dia que passasse, era uma perda para o produto, depois de cortada, tem pouco mais de 48 horas para ser moída e cozida, pois do contrário começa a perder sacarose e inicia-se o processo de fermentação. Com isso haveria a necessidade de acelerar o processo

\footnotetext{
${ }^{97}$ Ver: GODINHO, Vitorino Magalhães. Os descobrimentos e a economia mundial. Lisboa: Editorial Presença, 1963. v. 4. p. 96.

${ }^{98}$ VIEIRA, Alberto. Portugal y las islas del Atlántico. Madrid: Editorial MAPFRE, 1992. p. 15.

${ }^{99} \mathrm{O}$ autor mostra o tempo que levaria o processo desde o plantio até a corte da cana-de-açúcar, estabelece também uma relação do processo com o clima existente e os riachos: "A maturação faz em cinco ou seis meses, e o clima não impede que se plantem em qualquer mês e findo esse prazo sejam cortado a cana". Ver: GODINHO, Vitorino Magalhães. Os descobrimentos e a economia mundial. Lisboa: Editora Arcádia, 1965. v. 2. p. 455.
} 
produtivo através de inovações tecnológicas que cobrem o processo de corte, esmagamento e cozedura ${ }^{100}$.

No caso de São Tomé, após a cana-de-açúcar ser introduzida, logo no fím do século XV, os engenhos já se mostravam notáveis, embora não houvesse uma significativa produção exportável. Em 1495 já havia chegado o açúcar produzido em São Tomé a Antuérpia, no entanto, trava-se de amostra oferecida pelos produtores locais em uma tentativa de possibilidade de oferta naquele mercado consumidor ${ }^{101}$. Para Godinho $^{102}$ :

as plantações de cana-de-açúcar devem ter começado em 1485, ou pouco depois, mas durante uns vinte anos a transformação da indústria limitou-se ao espremer da cana, fabricando assim somente um suco grosseiro e essa transformação reduzida efetuava-se em alçapremas ou em trapiches de bestas (se não movidos a escravos) e é possível também que houvessem montado a moendas de água, mas sem que tivesse o reto do equipamento industrial.

\section{5 - Mão de obra na produção açucareira}

A principal força motora dos trabalhos nos engenhos era de braços humanos, que atuavam desde a plantação cana-de-açúcar até o produto final deste gênero. Assim para que pudesse atender as demandas crescentes do açúcar no mercado internacional, teria que encontrar grandes traços de bons terrenos e de mão de obra em abundância e fácil de recrutar. Como destaca Tenreiro:

Em toda parte, a cultua está ligada ao trabalho cativo. Só os escravos permitiam que uma cultura dispendiosa, não só pelas grandes traços de terra que requer, mas, sobretudo pelo número de trabalhadores, fosse compensada. No início, só o estado que possuía terra e escravatura, se abalava a ela. Mais tarde passa a ser também empreendimento de particulares. Cultura de colônias de plantação, intimamente ligado ao trabalho escravo ou compulsivo, pode ser considerada como tópica da região quente e úmida. Só nestas encontram terras livres e a mão de obra apropriada ${ }^{103}$.

\footnotetext{
${ }^{100}$ VIEIRA, Alberto. As Ilhas e a expansão da cultura e tecnologia da cana-de-açúcar no Atlântico nos séculos XV a XIX. Revista Labor \& Engenho. Campinas, v. 1, n. 1, p 1-20, 2007. p. 3.

${ }^{101}$ LAINS E SILVA, Hélder. São Tomé e Príncipe e a cultura do café. Lisboa: Junta de Investigações do Ultramar, 1958. p.83.

102 GODINHO, Vitorino Magalhães. Os descobrimentos e a economia mundial. Lisboa: Editora Arcádia, 1965. v. 2. p. 453.

${ }^{103}$ Se existiu um fato que facilitou a dinâmica do açúcar foi o trabalho escravo, pois para esta produção seus produtores necessitavam de uma mão-de-obra barata e um lucro altíssimo. Se tivessem que recrutar mão-de-obra em Portugal, ficaria muito caro, pois em Portugal, nesta época, havia escassez de trabalhadores o que levaria, atendendo a inelasticidade da oferta, a elevar o preço da mão-de-obra. Ver: TENREIRO, Francisco. A Ilha de São Tomé. Lisboa: Junta de Investigações do Ultramar, 1961. p. 67.
} 
O açúcar, pelo menos, quando começa a ser produzido nas regiões do Atlântico, as técnicas eram muito limitadas (embora os portugueses já houvessem conhecido técnicas daquela época para a produção do mesmo), o que veio a necessitar de uma grande força braçal para dar suporte à mesma. Quando se fala de técnica de produção açucareira introduzidas pelos mestres de açúcar madeirenses, genoveses e venezianos, está a se falar do modo como era produzido o açúcar em sua totalidade.

As técnicas da produção açucareira evoluíram no tempo, de acordo com as necessidades de cada época. Essa evolução gerou algumas polemicas quando se trata da época precisa, o país de origem e da passagem trapiche de mó de pedra vertical ao engenho de cilindros ou eixos de madeira. O pão de açúcar, tanto no Mediterrâneo como nas regiões açucareiras do Atlântico e no Brasil, depois de purgado e retirado da forma, é dividido em quatro partes, originando quatro diferentes qualidades de açúcar. Essas transformações apresentam as seguintes denominações: açúcar branco, o mais fino da base da forma; açúcar redondo, o que se segue ao mais branco; açúcar somenos, o menos branco do meio da forma; e açúcar mascavado, o mais escuro da parte inferior da forma ${ }^{104}$. As técnicas trouxeram uma grande vantagem para a indústria açucareira que até então não havia conhecido grandes evoluções. Uma das primeiras vantagens foi de acelerar o processo produtivo fazendo que uma produção que antes era feita em 24 horas, poderia ser feita em até duas horas. Outra vantagem é que com a aceleração do processo produtivo, faria aumentar a produção de forma vertical fazendo baratear o produto.

As técnicas produtivas foram evoluindo com o tempo e de acordo a necessidade do homem. O moinho de pedra vertical movido a água, surge na Sicília em 1475 por oposição ao termo simples trappeto de tração animal. Essa tecnologia siciliana do trappeto ainda resulta da adaptação das técnicas mediterrânicas do azeite e do vinho à produção açucareira, nomeadamente o antigo moinho de azeite de pedra vertical e a prensa de azeitonas, onde as canas, depois de esmagadas na macina, são introduzidas em sacos para serem espremidas na prensa, tal como acontecia com as azeitonas ${ }^{105}$. Como podem ser observados, muitos dessas técnicas de produção açucareira provém da

${ }^{104}$ NUNES, Naidea Nunes. O açúcar de cana na ilha da Madeira: do Mediterrâneo ao Atlântico Terminologia e tecnologia históricas e actuais da cultura açucareira. 2002. 778 f. Tese (Doutorado em Linguística Românica) - Faculdade de Artes e Humanidades, Universidade da Madeira, Funchal, 2002. p. 34.

${ }^{105}$ NUNES, Naidea Nunes. O açúcar de cana na ilha da Madeira: do Mediterrâneo ao Atlântico Terminologia e tecnologia históricas e actuais da cultura açucareira. 2002. 778 f. Tese (Doutorado em Linguística Românica) - Faculdade de Artes e Humanidades, Universidade da Madeira, Funchal, 2002. p. 164. 
adaptação da técnica que antes se usava para outras finalidades. Isso provavelmente ocorreu porque, algumas dessas produções caíam de rendimento assim surgiria à necessidade de se inovar aproveitando as ferramentas já existentes como forma de minimizar o custo de produção, e assim aperfeiçoar o rendimento. A prova disso é a transplantação de técnicas das principais regiões já produtoras de açúcar e a utilização de mão de obra escrava, uma forma de viabilizar o processo e reduzir o custo.

Nos tempos mais remotos as canas eram espremidas em alçapremas (ou trapiches), em engenhos muito rudimentares, sendo os cilindros destes construídos, algumas vezes de grossos troncos de til. O cultivo da cana-de-açúcar e as suas técnicas parecem ter surgido desde muito cedo na Andaluzia, introduzida pelos árabes, apresentando as mesmas técnicas sicilianas, também de origem árabe, que passam para Valência ${ }^{106}$. Essas técnicas são transplantadas para ilha da Madeira, sendo os trapiches os mais primitivos usados nessa região, dali passa para todas as terras descobertas e colonizadas por portugueses na África, nas ilhas do Atlântico e no Brasil. No Maranhão e noutras partes do Brasil dizia-se que ainda se fabricava açúcar pelo processo dos primitivos engenhos da Madeira ${ }^{107}$. A tecnologia primitiva da produção açucareira, na ilha da Madeira, é constituída pelo lagar e alçaprema (prensa manual) e por trapiches de bestas, moinho com uma mó de pedra vertical movida por animais, correspondendo ao trappetum e ao torculum do Mediterrâneo, resultante da adaptação da tecnologia do vinho e do azeite ao açúcar. A moenda dos primitivos engenhos de cana-de-açúcar é semelhante aos moinhos de cereais, com duas pedras molares ou mós, que ainda hoje existem para moer o milho, nas zonas rurais da Madeira e em muitas outras regiões portuguesas. A prensa utilizada para espremer a cana, depois de esmagada, também ainda hoje é utilizada, nestas regiões, para espremer o bagaço da uva e da azeitona, depois de pisada, extraindo totalmente o seu sumo em lagares, na produção familiar ou caseira $^{108}$. A ilha da Madeira desempenha um papel fundamental na transplantação da cultura açucareira do Mediterrâneo para o Atlântico. Segundo Alberto Vieira, Foi na Madeira que a cana-de-açúcar iniciou a expansão atlântica. Aqui surgiram os primeiros contornos sociais (a escravatura), e depois as técnicas de engenhos de água, posteriormente políticas econômicos (trilogia rural) que materializaram a civilização do

\footnotetext{
${ }^{106}$ NUNES, Naidea Nunes. O açúcar de cana na ilha da Madeira: do Mediterrâneo ao Atlântico Terminologia e tecnologia históricas e actuais da cultura açucareira. 2002. $778 \mathrm{f}$. Tese (Doutorado em Linguística Românica) - Faculdade de Artes e Humanidades, Universidade da Madeira, Funchal, 2002., p. 78.

${ }_{107}^{1}$ Ibid., p. 172

${ }^{108}$ Ibid., p. 171.
} 
açúcar. Assim, referindo S. Greenfield, o mesmo autor afirma que a ilha da Madeira foi o elo entre o Mediterranean sugar production e a Plantation Slavery americana ${ }^{109}$.

Os portugueses nessas aventuras tiveram uma vantagem, embora no início do século, não houvesse grandes competidores, pois eles haviam desde cedo experimentando uma experiência com tráfico ou captura de mão de obra nas regiões africanas de alta e baixa Guiné, que no momento que mais necessitaram de mão de obra, facilitou tais dinâmicas. A ilha de São Tomé foi originalmente colonizada na última década de século XV por levas de famílias brancas enviadas de Portugal, por crianças judias de ambos os sexos batizadas a força e, sobretudo, por criminosos e condenados deportados. Das crianças judias deportadas, as que sobreviviam uma vez crescidas, casavam-se. Um observador, em 1506, declarava que eram poucas as mulheres brancas que tinham filhos de homens brancos; a maioria tinha filhos com homens negros, enquanto mulheres negras tinham filhos de homens brancos.

Parece-me que havia uma espécie de sistema de procriação, uma forma de multiplicar a mão de obra existente. Segundo Boxer todos os homens solteiros dispunham de uma mulher negra concedida pela coroa, declaradamente para fins de procriação e a cerimônia de casamento parece ter sido optativa. Parece-me que na África bem como em muitos povos oriundos de trabalho escravo, se incutia essa cultura. Lembro-me que meu avô falava que teríamos que ter muitos filhos para ajudar no trabalho, provavelmente herança da cultura de procriação que perdurou por muito tempo nas regiões onde traficavam e usavam mão de obra escrava. Inclusive, muitas das vezes quando a esposa de um comerciante morre, ele toma uma negra e isso era uma prática aceita $^{110}$.

Para compor a povoado em São Tomé, os primeiros que lá foram depois dos descobridores foram colonos degradados e os escravos resgatados da Costa da Mina, depois de haver essas pequenas instalações do povoado, a primeira leva de população considerável ou importante, foi feita por João de Paiva em 1486, e em seguida feita por João Pereira em 1490. Nesta época já havia aproximadamente dois mil meninos pelos seus 8 anos, filhos de judeus castelhanos, de quem brutalmente eram separados. Os

\footnotetext{
${ }^{109}$ NUNES, Naidea Nunes. O açúcar de cana na ilha da Madeira: do Mediterrâneo ao Atlântico Terminologia e tecnologia históricas e actuais da cultura açucareira. 2002. $778 \mathrm{f}$. Tese (Doutorado em Linguística Românica) - Faculdade de Artes e Humanidades, Universidade da Madeira, Funchal, 2002., p. 173.

${ }^{110}$ BOXER, Charles. Relações raciais no Império colonial português: 1415-1825. Porto: Afrontamento, 1988. p. 20.
} 
objetivos do estado faziam trazer inocentes de forma cruel e como única garantia a bemaventurança eterna do batismo.

O processo da evolução populacional progrediu rapidamente, pois além do povoamento feito via degradados da metrópole condenados a morte, em São Tomé os escravos também eram destinados aos trabalhos e as escravas eram usadas para procriação. Os números de assassinos e ladrões da pior espécie, em 1506, eram de quatrocentos, o que somariam com seiscentos judeus com no máximo 21 anos, que haviam escapado da morte. Desses dois mil escravos trabalhavam na agricultura de sustentação, fixados na terra de seis a sete mil, sujeitos a criação e posteriormente seriam exportados.

O açúcar trouxe um grande estímulo para o aumento da população. A população cresceu rapidamente, pela necessidade crescente de mão de obra que se fazia sentir. Em meados do século XVI já havia, pelo menos, seiscentos a setecentos escravos, diz Lains e Silva ${ }^{111}$, e número de moradores variava em torno de três mil a três mil e quinhentos.

A população de São Tomé, em sua composição étnica era muito variada, no entanto, estavam presentes, desde os deportados, aventureiros, assassinos e ladrões, que na metrópole estariam condenados a morte ou corte de membro, judeus e comerciantes e por senhores de engenhos. Como afirma Lains e Silva ${ }^{112}$ :

A população de São Tomé e Príncipe na primeira metade do século XVI eram constituídos, de um lado por deportados, aventureiros, ladrões e assassinos, que na metrópole mereciam morte ou talhamento de membros, pequeno número de judeus e comerciantes e senhores de engenho; outro lado, grande massa de escravos africanos sujeitos a duríssimas condições de bichos. Entre os dois grupos, os mestiços, muito abundantes logo desde o princípio do povoamento, até porque a coroa animava a mestiçagem, que se sabia ser mais viável do que a produção entre os indivíduos brancos. Por isso cruzavam brancas com os negros e das negras com brancos.

A ideia de cruzamento de raças, mas especificamente, entre os homens brancos e as mulheres negras, bem como as mulheres brancas e os homens negros, era uma

\footnotetext{
${ }^{111}$ A população crescia rapidamente, não por ser grande aumento fisiológico, mas por continuar a imigração animada já pelo ciclo de açúcar. No Início do século XVI já havia seiscentos fogos (casas), isto é, três mil a três mil e quinhentos moradores. Em 1580 havia ao todo sete mil almas. Ver: LAINS E SILVA, Hélder. São Tomé e Príncipe e a cultura do café. Lisboa: Junta de Investigações do Ultramar, 1958. p. 71.

${ }^{112}$ Ibid., p. 72.
} 
estratégia de sobrevivência e adaptação ao local no qual se instalavam, pois existiam doenças nas quais os negros eram mais resistentes.

De certo modo, a população quando duplicou, poderia triplicar ou quadruplicar, sendo que existiam todas as condições para que aumentasse, não obstante as condições de trabalho e de higiene não permitiam esse aumento. Por ali existiam muitos mosquitos, principalmente na orla floresta, que faziam da vida dos moradores e dos escravos um inferno. As condições de higiene eram desfavoráveis, e a elas sucumbiam mais a vida dos brancos do que dos mestiços e negros. Muitas casas eram feita perto das florestas por causa das lenhas que todos os dias se usavam e gastavam para cozer açúcar.

Para Celso Furtado ${ }^{113}$, ao iniciar a guerra de secessão, os Estados Unidos tinha uma força de trabalho escravo de cerca de 4 milhões, e o Brasil, na mesma época, algo como 1,5 milhão. A explicação desse fenômeno, segundo o autor, seria uma elevada tava de crescimento vegetativo da população escrava norte-americana, grande parte da qual vivia em prosperidades relativamente pequenas, nos estados do chamado Old South As condições de alimentação e de trabalho nesses estados deveriam ser relativamente favoráveis, tanto mais que, com a elevação permanente de preços dos escravos, seus proprietários passaram a derivar uma renda do incremento manual dos mesmos.

Os escravos nascidos no país apresentavam evidentemente inúmeras vantagens, pois estavam culturalmente integrados nas comunidades de trabalho que eram as plantações, haviam sido mais bem alimentados, já tinham o conhecimento da língua, etc. $\mathrm{O}$ fato de que a população escrava brasileira tivesse uma taxa de mortalidade bem superior à de natalidade indica que as condições de vida da mesma deviam ser extremamente precárias. O regime alimentar da massa escrava ocupada nas plantações açucareiras era particularmente deficiente. Ao crescer a procura de escravos no sul para as plantações de café, intensificava-se o tráfico interno, em prejuízo das regiões que já estavam operando com rentabilidade reduzida. Apesar da produção açucareira, em grande escala, ter exigido uma grande massa de mão de obra para impulsionar a produção, é de se assinalar que nem sempre isso foi assim.

No início da produção, na ilha da Madeira e nas outras regiões do Atlântico, quando a produção era feita em pequenas escalas e pelos pequenos proprietários, a mão

\footnotetext{
${ }^{113}$ FURTADO, Celso. Formação Econômica do Brasil. 32ª ed. São Paulo: Companhia Editora Nacional 2005. p. 78-79.
} 
de obra, não era escrava africana. Para Alberto Vieira ${ }^{114}$ a cana-de-açúcar não está na origem da escravidão africana, embora possua uma forte correlação com a mesma. A escravização dos africanos só se deu em momento posterior, quando a produção se encontrava em escalas avançadas. Para o mesmo autor, quando essa cultura era em pequenas parcelas, a maior parte das questões não se colocava, mas quando se avançou a produção pra larga escala, houve necessidade de encontrar soluções capazes de resolver a situação, através da aceleração do processo de moenda e do fabrico. A necessidade de recrutar mão de obra escrava se deu partir de meados do século XV na Madeira com aumento de procura do açúcar e a ampliação da escala produtiva o que veio a implicar mudanças radicais na tecnologia usada e na afirmação da escravatura dos indígenas das Canárias e os negros da Costa da Guiné ${ }^{115}$.

A necessidade de justificar o crescimento do número de escravos africanos levou os papas Nicolau V e Calisto III a expedir bulas (em 1454 e 1456, respectivamente), apresentando a expansão portuguesa na África como uma cruzada de cristianização do continente africano. Nessa perspectiva, a escravização dos africanos pelos cristãos era vista como sendo do próprio interesse dos autóctones pagãos, argumento esse reforçado pelo mito bíblico segundo o qual os descendentes de Ham, um dos filhos de Noé, eram amaldiçoados e destinados à escravidão. Tal dimensão bíblica e religiosa, por ser de grande alcance, fundava e justificava muito oportunamente ideias relativas à natureza inferior e selvagem dos africanos ${ }^{116}$.

Os portugueses ao longo do século XV tiveram um grande interesse pelo comércio dos escravos, devido à demanda que se fazia, por conta de aumento da produção e por outro lado, a peste bubônica, que dizimou quase um terço da população europeia, fizesse com a busca pela mão de obra se fizesse sentir com maior necessidade. $\mathrm{O}$ continente que possuía mão de obra em quantidade e fácil de ser recrutado era o continente africano, pela própria cultura de terem muitos filhos, devido tais necessidades a busca nesse continente aumentou consideravelmente. Por esse motivo, a

\footnotetext{
${ }^{114}$ VIEIRA, Alberto. As Ilhas e a expansão da cultura e tecnologia da cana-de-açúcar no Atlântico nos séculos XV a XIX. Revista Labor \& Engenho. Campinas, v. 1, n. 1, p 1-20, 2007. p. 3.

115“'A cana-de-açúcar não está na origem da escravidão africana, mas no processo de afirmação, a partir da Madeira. Enquanto a cultura se fazia em pequenas parcelas, as maiores partes das questões não se colocavam, mas quando se avançou para uma produção em larga escala, houve necessidade de encontrar soluções capazes de resolver a situação, através da aceleração do processo de moenda e fabrico". Ver: VIEIRA, Alberto. As Ilhas e a expansão da cultura e tecnologia da cana-de-açúcar no Atlântico nos séculos XV a XIX. Revista Labor \& Engenho. Campinas, v. 1, n. 1, p 1-20, 2007. p. 3.

116 OGOT, Bethwell Allan (Ed.). História geral da África, V: África do século XVI ao XVIII. Brasília: UNESCO, 2010. p. 136.
} 
penetração portuguesa na costa africana e especificamente na região do Congo, uma região onde não havia nem ouro e nem prata, e a conquista posterior de Angola, que foi precedida pelo rápido avanço do comércio de escravos na ilha de Luanda. A maior preocupação dos colonos em São Tomé era obter grandes quantidades de escravos, não só porque eles precisavam desta mão de obra para suas plantações, mas também, porque vendiam os escravos às colônias espanholas da América e, a partir do fim do século XVI, também às colônias portuguesas. A população negra deste país, que era somente de alguns milhares de indivíduos, sofreu, no século seguinte, um brusco aumento, da ordem de 400.000 a 450.000 pessoas, atribuído ao desenvolvimento da cana-deaçúcar $^{117}$.

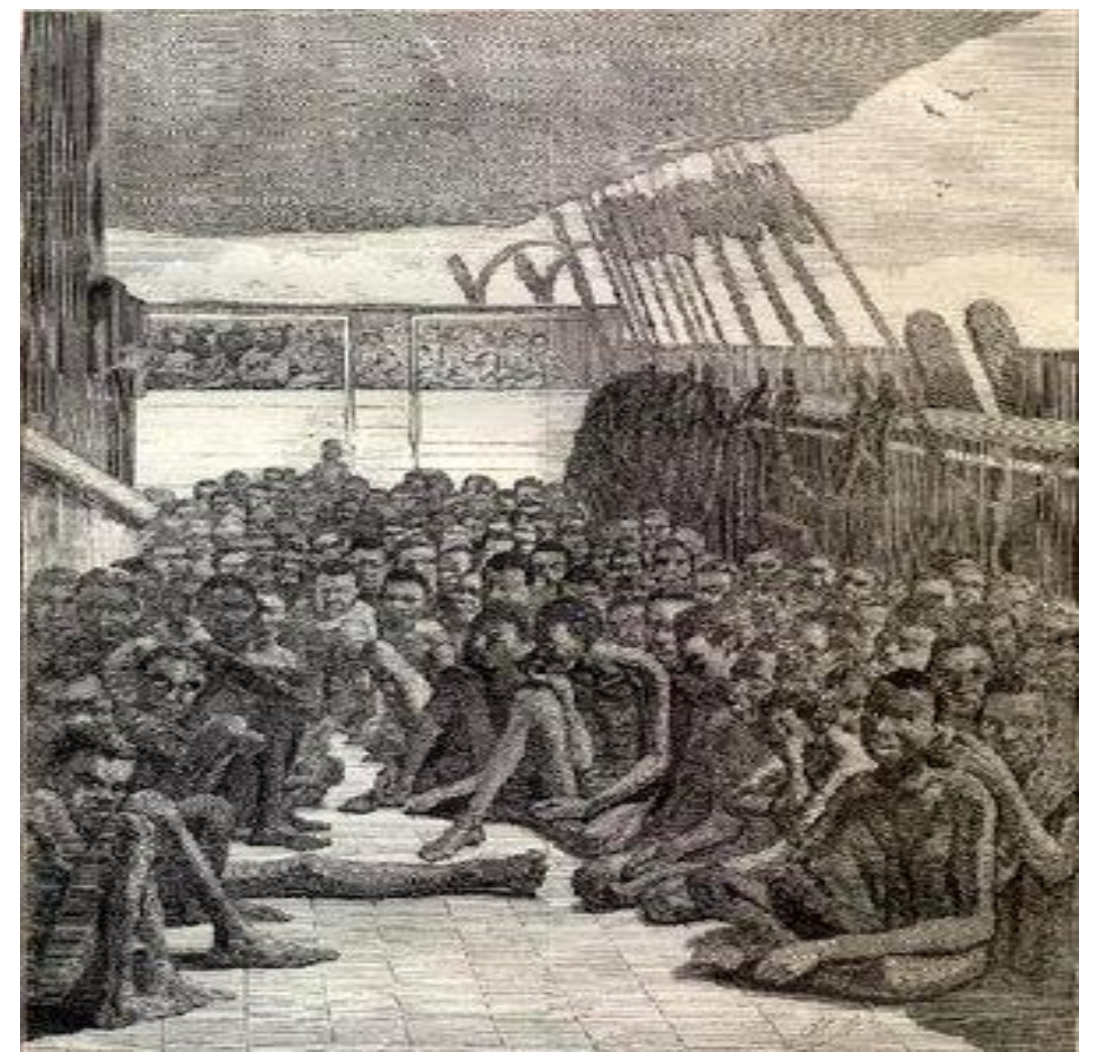

Figura 2: Escravos saindo de São Tomé com Destino as Américas (1781). Fonte: http://www.odisseiasnosmares.com

\footnotetext{
117 "Os portugueses tiveram, igualmente, sérios problemas na África. Durante todo o século XV, eles tiveram um crescente interesse pelo comércio dos escravos e, ao longo do século XVI, como nos outros seguintes, os territórios capazes de lhes fornecerem escravos em grande quantidade, cada vez mais, suscitavam - lhes cobiça. É sob esta ótica que é preciso alocar a penetração portuguesa no Congo (onde não havia nem ouro e nem prata), encetada no começo do século XVI, e a conquista posterior de Angola, que foi precedida pelo rápido avanço do comércio de escravos na ilha de Luanda ". Ver: OGOT, Bethwell Allan (Ed.). História geral da África, V: África do século XVI ao XVIII. Brasília: UNESCO, 2010. p. 10 .
} 
A forma de trabalho feita nas ilhas do Atlântico era diferente da praticada posteriormente no Brasil e nas Ilhas do Caribe. Tudo leva a crer que o trabalho era mais parecido com a servidão que a escravidão. Além de trabalhadores se dedicavam ao trabalho da produção açucareira, que era a atividade principal, dentre esses trabalhadores, havia muitos que se dedicavam a outras atividades secundaria, nas quais, esses teriam seus trabalhadores (escravos). Subsequentemente, cada um desses habitantes comprava seus escravos (negros), acompanhado de uma mulher (negra), formando assim um casal de escravos. Nessa analogia, tudo leva a crer que os trabalhadores tinham um trabalho bem recompensado, ao ponto, que depois de certo tempo trabalho, conseguiriam destacar e ser senhor de si mesmo. Os homens ricos possuíam de 150 a 200, mesma até 300 , entre os negros e as negras, os quais tinham obrigação de trabalhar toda a semana para seu senhor, exceto aos sábados, que seria reservado para trabalharem nos cultivos alimentos para sua manutenção. Neste dia semeavam milhos (zaburro), raízes de inhame, e muitas hortaliças domésticas, tais como: alfaces, couves, rabanetes, beterrabas e aipo, depois de crescerem são usados como fonte da própria alimentação ${ }^{118}$. Os colonos portugueses moradores de São Tomé estavam dependentes dos abastecimentos regulares de alimentos vindos de Portugal, assim procuravam introduzir espécies fundamentais da sua alimentação nas novas terras onde se estabeleciam.

\section{6 - Comércio do açúcar no mundo Atlântico}

O Atlântico sempre esteve na mira dos portugueses desde o reinado do D. Fernando, mas me parece que essa estratégia tenha sido inviabilizada por algumas questões internas de Portugal. Isso estaria muito claro nas guerras de D. Fernando que se esboçava o triunfo de uma estratégia voltada para o Atlântico sobre a estratégia Ibérica. Tais estratégias atlânticas eram essencialmente uma estratégia norte - atlântica, que estaria, sobretudo ligada a Inglaterra e com intervenção nas linhas de comércio marítimo que liga Flandres aos portos italianos ${ }^{119}$. Parece-me que era necessária

\footnotetext{
${ }^{118}$ Se existiu escravidão em São Tomé, era bem diferente da praticada em outras partes do continente, pois os escravos não trabalhavam todos os dias e além do mais, tinham direito a uma mulher como forma de procriarem. Os sábados, dia de folga, eram usados para plantar os seus viveres para seus mantimentos. Isso talvez ocorresse porque os colonos ali instalados preferiam os alimentos vindos da metrópole, com os quais estavam mais acostumados. Ver: Loureiro, Rui. Navegação de Lisboa à Ilha de São Tomé: escrita por um piloto português. Lisboa: Grupo de trabalho de ministérios da educação para comemorações dos descobrimentos portugueses, 1989.

${ }^{119}$ A ideia de Portugal em se penetrar no Atlântico já estava provavelmente fixada desde, pelo menos o século XII, mas existiram alguns obstáculos que impossibilitasse tais aventuras. Na época, precisava de
} 
alguma motivação adicional para que de fato esses ideais se concretizassem, sendo depois que o comércio na ilha da Madeira mostrou-se viável o surgimento do interesse maior da coroa portuguesa em implementar em outras regiões com característica parecidas, que seria o caso sucessivo da ilha do golfo da Guiné. Antes dessa ocupação, provavelmente a coroa portuguesa e o resto da Europa, tinha atenção voltada para o continente, mais especificamente norte da Europa, é para esse lado que Infante D. Henrique, estava obcecado. Como indica o Thomaz (1994):

Foram provavelmente eles que, logo em 1419, atraíram para o Atlântico as intenções de D. Henrique, aí ao obcecado por Marrocos e por Granada, e, numa segunda fase, as atenções da própria Coroa que desde 1425começa a intervir no processo. São os começos promissores do povoamento das ilhas, logo de seguida dos descobrimentos da costa Saarina, que permitem ao regente D. Pedro esboçar pela primeira vez uma política coerente da expansão marítima, alternativa a então indesejável conquista de Marrocos ${ }^{120}$.

O sucesso da ilha da Madeira foi medida certa para abrir as portas para o interesse pelo mundo Atlântico, que antes, não era o centro das atenções. Creio que devido às características semelhantes das ilhas, fez expandir o comércio para o resto do Atlântico.

Embora houvesse uma relação muito estreita, nem sempre a produção açucareira era acompanha com o comércio em grande escala, pelo menos o que ocorreu em São Tomé após o início das instalações dos engenhos. As intenções comerciais não estão de modo alguns ausentes nos projetos Henriquinos, pelo menos como objetivos imediatos capazes de garantirem o futuro financeiro a empresas de maior envergadura e, por então, de maior prestígio ${ }^{121}$. Uma carta regia de 11 de dezembro de 1493 , segundo Godinho $^{122}$, parece indicar que nesta altura já se exportaria açúcar de São Tomé, ou estava prestes a exportar, pelo menos para o país vizinho, São Jorge de Mina, paga em meio Cruzado, preço de cada arroba que os moradores da ilha entregavam nesta feitoria ao feitor Del-Rei.

um bom navio capaz de executar tais aventuras e uma boa motivação para se mergulhar no Atlântico abaixo, mas talvez gerava alguma incerteza na obtenção de um bom retorno nessas aventuras. Ver: THOMAZ, Luís Filipe Ferreira Reis. De Ceuta a Timor. Linda-a-velha: Difel, 1994.

${ }^{120} \mathrm{O}$ desejo pelo mundo atlântico já predominava na Europa século antes da sua ocupação e o sucesso de algumas ilhas intensificou o interesse. Ver: THOMAZ, Luís Filipe Ferreira Reis. De Ceuta a Timor. Linda-a-velha: Difel, 1994. p. 154.

${ }^{121}$ THOMAZ, Luís Filipe Ferreira Reis. De Ceuta a Timor. Linda-a-velha: Difel, 1994. p. 159.

122 GODINHO, Vitorino Magalhães. Os descobrimentos e a economia mundial. Lisboa: Editorial Presença, 1963. v. 4. 
A baixa do preço, a meu ver, teve uma grande contribuição para disseminação do produto, sendo que antes, o produto era pouco conhecido e era consumido pela classe alta da sociedade. A baixa de preço fez com que mais gente pudesse consumir o produto e dessa forma aumentar a produção. Mas depois do comércio ser expandido, devido à abundância de metais preciosos e do aumento geral do consumo, que se fez sentir no século XVI, resultou nesta época uma elevação do preço dos produtos em geral e do açúcar. A elevação do preço do açúcar não se deu somente pelo aumento generalizado do consumo e abundância dos metais, também por conta das retrações produtivas em outras regiões, onde antes se produzia o produto. Lains e Silva ${ }^{123}$ destaca que:

Assim, por exemplo, na década de 1511 a 1520 duplica o preço do açúcar, o qual continua a aumentar até meados do século XVII. Além disso, a indústria açucareira foi destruída na síria e no Egito, que os Árabes conquistaram em 1517, o que não podia deixar de animar a produção em outras regiões.

Embora não fique muito claro, em muitos trabalhos aqui observados, a expansão do açúcar, inicialmente na Europa e posteriormente no mundo deve-se também, ou fundamentalmente a baixa do preço, embora houvesse outros fatores que também teve grande participação e contribuiu para expansão do mesmo. Aponta Lains e Silva ${ }^{124}$, que a expansão da cultura cana sacarina pelas ilhas do Atlântico, no século XVI, foi animada pelas condições favoráveis do mercado consumidor, principalmente em Flandres, Grã-Bretanha e portos da Itália e recebeu forte impulso do aumento da escravatura, que fornecia a indústria mão de obra para funcionamento dos engenhos nessas ilhas.

A prosperidade de São Tomé girava em torno da dinâmica do açúcar e posteriormente do comércio de escravos, uma guinchando a outra. Por ano muito navios partiam da ilha de São Tomé com grande carregamento de açúcar, que na sua grande maioria seguiam para o mercado de Flandres e outros barcos, no sentido contrário, vindo da Metrópole, traziam produtos, entre as quais se constavam farinhas de trigo,

\footnotetext{
${ }^{123}$ Depois que o açúcar passou a ser conhecido se valorizou, pelo aumento do consumo, e associado à abundância de metais preciosos ocasionou, ao longo do século, alta nos preços dos produtos (inclusive do açúcar). Ver: LAINS E SILVA, Hélder. São Tomé e Príncipe e a cultura do café. Lisboa: Junta de Investigações do Ultramar, 1958. p. 81.

${ }^{124}$ LAINS E SILVA, Hélder. São Tomé e Príncipe e a cultura do café. Lisboa: Junta de Investigações do Ultramar, 1958. p. 81.
} 
vinhos, o azeite, o queijo, os couros, taças de vidro, contas e espadas ${ }^{125}$. Nessa ilha iam muitos comerciantes de quase toda a Europa, como muitos deles não estavam acostumados com alimentos e vida que por lá se vivia, esses europeus necessitavam e mandam vir de metrópole os alimentos e produtos a que estavam acostumados.

\section{7 - Relação da igreja católica com o comércio do açúcar}

Ao longo da Idade Média a igreja teve um papel preponderante na sociedade. Como a maioria das questões cotidianas eram baseadas no cenário religioso, e a Igreja Católica era detentora do cenário religioso e do poder espiritual, acabava influenciando o modo de pensar e as formas de comportamento da época. O poder estava sobre o domínio da igreja católica e a mesma, passou a controlar grande parte dos territórios feudais, se transformando em uma importante chave na manutenção e das decisões do poder nobiliárquico.

Aqueles que viam a influência político-econômica da igreja uma ameaça aos princípios religiosos começaram a se concentrar em ordens religiosas que se abstinham de qualquer tipo de regalia ou conforto material. Essa cisão nas práticas da igreja veio subdividir o clero em duas vertentes: o clero secular, que administrava os bens da igreja e a representava nas questões políticas; e o clero regular, composto pelas ordens religiosas mais voltadas às praticas espirituais e a pregação de valores cristãos. Os interesses comerciais andavam mesclados, de alguma forma com o interesse religioso, quando o comércio avançou foram os cristãos católicos quem davam suporte com cativo de mão de obra escrava, bem como auxiliava na própria dinâmica interna.

A igreja teve um papel importante no processo da civilização, da expansão marítima e no comércio, a sua intervenção mediava os interesses europeus e das outras civilizações, como forma de viabilizar o processo. Essa situação fica clara quando na tentativa de D. João II cristianizar o continente africano em 1491, que juntaria o batismo do rei de Jalofos e o próprio envio de missionários para o Benim ${ }^{126}$. A principal ideia é mostrar que, com ajuda da igreja, o desenvolvimento do comércio fica mais fácil e a influência sobre alguma ação social seria viabilizada, do que quando não tem associação com a igreja. Muitos acreditavam na religião como uma forma de terem ou continuarem a vida após a morte e os grandes comerciantes juntos com a igreja,

\footnotetext{
${ }^{125}$ TENREIRO, Francisco. A Ilha de São Tomé. Lisboa: Junta de Investigações do Ultramar, 1961.

${ }^{126}$ THOMAZ, Luís Filipe Ferreira Reis. De Ceuta a Timor. Linda-a-velha: Difel, 1994. p. 163.
} 
aproveitavam disso de algum modo. A religião certamente teve uma participação muito grande na sociedade medieval e esteve muito presente no processo produtivo, como mostra-nos Boxer ${ }^{127}$, o rei de Portugal sempre permaneceu na conquista do oriente unindo tanto o poder espiritual e o temporal, que em nenhum tempo um se exercesse um sem o outro. Nas emboscadas de captura dos escravos, sempre que aconteciam os confrontos religiosos, o mais comum é o do cristianismo e o Islã, na Ásia e na África, os esforços portugueses de proselitismo entre os mouros não obtiveram grandes sucessos. As inversões limitavam-se somente a pessoas que tinha sido capturadas ou escravizadas quando crianças ou adultos que procuravam refúgio nas fortalezas portuguesas por razões pessoais e que não tinham esperança de voltar para seus parentes e amigos. E as viagens dos portugueses de descobrimentos e comércio, tiveram vários contatos com populações de Sene - Gâmbia e da Guiné e os seus esforços missionários tiveram muito sucesso junto dos povos que ainda não tiveram influenciados pelos Islamismos ${ }^{128}$. Como já foi enfatizado acima, apesar de haver essa mescla da religiosa e outras atividades feitas pelos colonos portugueses na África e na Ásia, por não ser objetivos centrais que levavam esses colonos a tais aventuras, ela acabavam não tento muito sucesso. O sucesso sempre era conseguido nas perspectivas inicias, mas depois perde seu impacto, como sinaliza bem o Boxer ${ }^{129}$ :

O proselitismo português no Congo e em Angola também tinha perdido seu ímpeto, por essa altura, apesar de um início muito promissor no velho reino de Congo, princípio do século XVI. Este fracasso na África Ocidental, relativo ou total, foi atribuído por Serafim Faria, a três causa principais.

A religião tinha seu papel em todo o processo de colonização do Atlântico, ela intermediava ações de outras ordens, como exemplo já mencionada, no momento de captura de negros na costa africana, desempenhou um grande papel. Muitos se refugiavam em uma determinada religião, ou porque não tinha nenhuma religião ou se tivessem já a sua religião, ateria a outra como forma de refúgio, muitos casos, como forma de se ater a uma que desse algum tipo de acolhimento. $\mathrm{O}$ insucesso da religiões católicas na região da África e na Ásia, muitas das vezes ocorria pelo fato do objetivo central ali não serem os serviços religiosos, porém ela não se recuava mediante tais

127 BOXER, Charles Ralph. Relações raciais no Império colonial português: 1415-1825. Porto: Afrontamento, 1988. p. 9.

${ }^{128}$ Ibid., p. 12.

${ }^{129}$ Ibid., p. 13. 
situações de insucesso, porque a sua presença nessas ações era de certa forma necessária. Uma das causas que levou ao insucesso da igreja católica onde proselitismo se fazia era devido, de acordo como Boxer ${ }^{130}$, a inaptidão do pessoal missionário, pois os bispos, normalmente tinham relutância em ir para dioceses tão insulares como Cabo Verde, São Tomé e Congo, e normalmente quando iam, morriam de alguma febre tropical antes que pudessem cumprir a sua missão. $\mathrm{Na}$ época, a maioria dos missionários eram brancos e eram eles que podiam ser levadas a prestar serviços nas regiões africanas demandadas. Os mesmos pareciam ser mais ativos no comércio de escravatura do que celebrar missa ou desempenhar alguma função religiosa ${ }^{131}$. Outro ponto do proselitismo não obter sucesso, estaria no fato de muitos cristãos exemplares entres os leigos portugueses e mulatos, a maioria era formada por criminosos deportados ou aventureiros, que tinha como único objetivo tornarem-se ricos o mais depressa possível, assim tornava a principal prioridade nessas missões, a atividade no comércio de escravo, transformando dessa forma, um grande entrave ao trabalho de conversão $^{132}$. No entanto, os interesses comerciais e missionários dificilmente se conciliavam, e quando entravam em conflito, eram normalmente os comerciais que prevaleciam. Boxer ${ }^{133}$, mostra-nos que apesar de haver grandes estabelecimentos eclesiástico em São Tomé, Congo e em Angola, os mesmos eram mantidos pelos lucros dos comércios de escravos.

O interesse pelos negros africanos da costa de Guiné surge por motivos vários, e um dos tais já aqui mencionado. A demanda crescente pela mão de obra que se fazia sentir, a tradição dos próprios africanos de exportar mão de obra para países árabes, experiência de Portugal no mercado escravo. O interesse inicial de Portugal na costa africana, não era tráfico de escravos, mas sim o ouro, que era anteriormente exportado pelos países islâmicos, não tardou muito, eles aperceberam-se que na África possuía outra mercadoria, também fortemente procurada pelos Europeus: os escravos. Embora a escravidão na África fosse diferente da escravidão praticada pelos europeus, a tradição de exportar escravos para os países árabes era muito antiga em grandes partes do

${ }^{130}$ BOXER, Charles Ralph. Relações raciais no Império colonial português: 1415-1825. Porto: Afrontamento, 1988. p. 13.

${ }^{131}$ Ver: BOXER, Charles Ralph. Relações raciais no Império colonial português: 1415-1825. Porto: Afrontamento, 1988. p. 13.

${ }^{132}$ Ver: BOXER, Charles Ralph. Relações raciais no Império colonial português: 1415-1825. Porto: Afrontamento, 1988. p. 13.

${ }^{133}$ BOXER, Charles Ralph. Relações raciais no Império colonial português: 1415-1825. Porto: Afrontamento, 1988. p. 14. 
continente, em particular do Sudão, uma região que mais concentrou a procura de tais mãos de obra ${ }^{134}$.

Talvez a razão pela qual a religião tivesse esse papel na intermediação comercial nas costas africanas e na Ásia, seria pelo fato de muitas pessoas, nesta época acreditarem na vida pós a morte. Posto isso, muitos considerados eclesiásticos eram vistos como um caminho para que chegasse a Deus. O poder divino também era visto nos reis de diferentes tribos, os reis eram adorados pelos povos, pois, acreditavam que viessem do céu (ou seria o que os mesmos reis passavam para a população), e as populações (crentes) falavam-lhes com grande acatamento, à distância e de joelhos ${ }^{135}$. Muitos dos reis ou eclesiásticos, para algum cerimonial, nunca se deixavam ver quando comem, para não modificarem a opinião que os povos deles tinham, de que vivem sem tomar alimento, costumavam adorar o sol acreditavam que as almas são imortais e que depois da morte vão habitar junto ao sol ${ }^{136}$. Rui Loureiro aponta o seguinte:

No reino de Benim têm costume mais antigo entre outros, o qual tem sido observado até ao presente: quando morre o Rei, todo o povo se junta num grande campo, no meio do qual abrem um poço muito fundo, ficando largo em baixo e vindo a apertar para a boca. Dentro desse poço deitam o corpo do rei morto, e apresentando-se todos os seus amigos e servidores, aqueles que se julga terem-lhes sido mais caros e favoritos (no que não há pequena contenda entre eles, desejando todos esta honra), voluntariamente descem a fazer-lhe companhia; e logo que estão em baixo, põe-se uma grande lage sobre a boca do poço, e povo não sai dali, nem o dia nem de noite. No segundo dia vão alguns deputados descobrir a pedra, e perguntam aos de baixo se algum deles já serviu ao rei, e respondem que não. No terceiro dia fazem a mesma pergunta, e algumas vezes lhes respondem que fulano (dizendo-lhes o nome) foi primeiro a partir, e fulano segundo, porque é reputada coisa de grande louvor ter sido o primeiro. E tudo isso o povo que esta a roda fica falando co suma admiração,

\footnotetext{
${ }^{134}$ OGOT, Bethwell Allan (Ed.). História geral da África, V: África do século XVI ao XVIII. Brasília: UNESCO, 2010. p. 8.

135 A vida após a morte era muito apreciada na Idade Média. Uma vez que tudo ou quase tudo era fundamentado no divino: Sol, Vento, Tempestade, Bonança, Seca, até uma Crise, era fundamentada em Deus. Havia Deus em tudo e a Igreja e os Reis baseavam-se nisso para tirarem proveito juntos aos fiéis. Ver: LOUREIRO, Rui. Navegação de Lisboa à Ilha de São Tomé: escrita por um piloto português. Lisboa: Grupo de trabalho de ministérios da educação para comemorações dos descobrimentos portugueses, 1989. p. 17.

${ }^{136}$ Existia Deus para tudo, mas o Deus do Sol era um grande Deus ou o principal, muitos acreditavam ser o superior dos superiores. Ver: LOUREIRO, Rui. Navegação de Lisboa à Ilha de São Tomé: escrita por um piloto português. Lisboa: Grupo de trabalho de ministérios da educação para comemorações dos descobrimentos portugueses, 1989. p. 15.
} 
considerando-o bem-aventurado e feliz. E ao fim do de três duas ou quatro dias morem todos aqueles desgraçados ${ }^{137}$.

Alguns costumes são mantidos e vivenciados até os dias de hoje, que é o caso de Benim, demonstrando o quanto a igreja poderia exercer influência sobre a população por conta dessas crenças. Hoje observando as influências da religião sobre os crentes ficaria mais fácil entender o processo de escravização e a inserção do povo na produção dos bens antes demandantes. As obrigações com a igreja constam na própria bíblia sagrada, nas quais os fiéis devem devolver ao Senhor o dízimo, ou seja, oferecer dez por cento de suas rendas à igreja; também devem dar ofertas voluntárias e essas ofertas devem ser proporcionais aos lucros obtidos nos seus trabalhos, ainda que estes sejam de pequeno valor. A igreja teve o papel importante no processo de escravização e grande participação nas empresas coloniais instaladas no Atlântico. Nas regiões onde não havia essas crenças, a igreja católica forçava-lhes ao batismo, tudo em nome de Deus e da salvação, para que no futuro, depois de convertidos, pudessem manipular e tê-los ao dispor da igreja ou do rei.

\section{8- A decadência do açúcar}

Se dissessem aos proprietários produtores de açúcar, do final do século XVI que um dia esse comércio iria falir ou entrar em decadência, dificilmente eles acreditariam, pois nessa época o comércio ali instalado mostrou-se muito rentável e infinitamente próspero. Devido às características apresentadas pelas ilhas: a fertilidade do solo, clima favorável e mão de obra disponível, vieram a facilitar e proporcionar o negócio, que até o final do século XVII ainda era grande triunfo da coroa portuguesa. Os solos de São Tomé resultam essencialmente de ação conjunta de vários fatores: primeiramente do vigor e movimento do relevo, da quantidade de microrganismos neles existentes, da vegetação que suportam e o fator tempo que se adequou a todo o processo. Para Tenreiro $^{138}$, poucas áreas no mundo gozam da fama de tão extrema fertilidade como a de São Tomé. O mesmo autor baseou-se num observador, o piloto anônimo português, que passou nessas ilhas no século XVI para afirmar o seguinte: "a terra é gorda como

\footnotetext{
${ }^{137}$ LOUREIRO, Rui. Navegação de Lisboa à Ilha de São Tomé: escrita por um piloto português. Lisboa: Grupo de trabalho de ministérios da educação para comemorações dos descobrimentos portugueses, 1989. p. 15.

${ }^{138}$ TENREIRO, Francisco. A Ilha de São Tomé. Lisboa: Junta de Investigações do Ultramar, 1961. p. 45.
} 
greda forte, e isto pelas condições climáticas, isto é, pelos muitos orvalhos que cai todas as noites continuamente, o que faz com que produza bem o que planta". Como já foi observado, após a descoberta, foi concedido o direito aos donatários, de resgatar os escravos nas costas africanas, que passariam a ficar nessa ilha para depois serem enviados para outras regiões que os demandassem e no final do século XVI, com a instalação dos engenhos produtores do açúcar. Provavelmente, utilizaram partes dessa mão de obra, uma vez que nesta altura já existiam, aproximadamente 5000 a 6000 escravos de resgate, além dos 2000 homens que dedicavam à agricultura dos seus senhores, somando um total de 10.000 almas, pois além dos escravos resgatados na costa africana e homens livres, haviam também homens de negócios e a classe eclesiástica. São Tomé era então um entreposto de escravos caçados na costa de Guiné, em guerras propositadamente provocadas para isso. Em São Tomé aguardavam momento de embarque para a metrópole, ou para a Costa da Mina e, mais tarde, terras do sul, onde serviam ao resgate do ouro. As tripulações dos navios negreiros recebiam grandes recompensa pela tramitação dos escravos. Esse comércio era muito rentável ${ }^{139}$. A cultura da cana-de-açúcar, em São Tomé estava estritamente ligada a trabalho escravo e nessa região se encontrava terras baixas e ricas, abundância de rios, cuja água servia para movimentar os engenhos, regar os campos e escoar os detritos. Além da mão de obra que era favorecida pela ilha, as instalações dos engenhos foram feitas na região nordeste, onde se apresentava ideal para mesma cultura.

A economia de São Tomé, no século XVI era baseada na produção açucareira e mais tarde no comércio de escravos. Produzia-se mais de 300.000 arrobas de açúcar por ano e partiam da ilha navios levando grandes carregamentos, na sua maioria seguiam para o mercado de Flandres e em contrapartida, outros barcos viam da metrópole trazendo produtos como queijos, vinhos, azeite, taças de vidros, e entre outros bens nas quais demandavam os colonos e os moradores locais. Os colonos europeus e boa parte dos moradores locais, não estavam acostumados a consumir os produtos que os escravos usavam, por isso mandavam vir da metrópole os alimentos a que estavam habituados. Francisco Tenreiro, busca o depoimento do Piloto Português para explicar o seguinte:

A importação se devia ao fato de os brancos não se acostumarem à comida dos negros. Razão simplista afinal, mas que

${ }^{139}$ São Tomé, no final do século XVI, desempenhava o papel de armazém de escravos caçados no Golfo da Guiné, em guerras propositadamente provocadas com essa finalidade. Ver: LOPES, Edmundo Correia. A escravatura: subsídios para a sua história. Lisboa: Editorial Atica, 1944. 
traduz, em última análise a exploração da terra em regimento de monocultura por parte do branco e quiçá a valorização da mesma, por parte do negro, através de uma policultura com base em produtos introduzidos de África e até outros de Mediterrâneo, como maioria das hortaliças ${ }^{140}$.

Pelo fato dos colonos não estarem habituados a consumir os produtos importados da metrópole, certamente criaria uma espécie obstáculo quando ao desenvolvimento da economia local, pois, isso levava os mesmos somente a introduzir os produtos que lhes interessassem ao comércio, ignorando, em grande medida, a agricultura que daria o sustento da grande parte da massa da população, que era até então a sua principal força de trabalho. Esses trabalhadores escravos tinham por obrigação trabalhar seis dias da semana, exceto o sábado, que era reservado para se organizarem e plantarem o necessário para seus próprios mantimentos. Nessas condições ficaria difícil haver uma satisfação por parte desses escravos, tinham quatro dias em trinta dias para seu sustento, e esses dias não eram para seu descanso, mas sim para trabalhar para se manterem. Os senhores de engenho não faziam quaisquer despesas com seus trabalhadores, no entanto, as despesas com vestuários alimentação e habitação eram tudo por conta dos mesmos. Esses, no dia livre providenciavam as suas necessidades, dedicando a pequena agricultura ou agricultura de subsistência, como milho zaburro, o inhame, hortaliças, etc., para se alimentarem ${ }^{141}$. Essa situação, ao longo do tempo veio provavelmente, criar uma grande insatisfação por parte desses trabalhadores, que veio a resultar em revoltas.

A cultura florescente do açúcar no Brasil, em finais do século XVI, quando entra no cenário, cria dificuldades ao comércio de São Tomé e ao da Madeira, empresas representativas em produção açucareira, pelos menos por um século e meio. Isso foi não só uma consequência das incomensuráveis possibilidades do Brasil em terras para o açúcar e da política ultramarina portuguesa, que depositou na América do Sul e na Índia todos os seus sonhos de grandeza, bem como as especulações de que o açúcar de São Tomé tinha uma qualidade inferior ao que se produzia na Madeira e no Brasil. Lamentavelmente, porém, a heterogeneidade da população, conjugada a ação do clima, bem como outros fatores, como a falta de preparação e espírito de ganância de muitos governadores, davam origem a constantes rixas e desentendimentos entre as diversas

\footnotetext{
${ }^{140}$ TENREIRO, Francisco. A Ilha de São Tomé. Lisboa: Junta de Investigações do Ultramar, 1961. p. 72.

${ }^{141}$ TENREIRO, Francisco. A Ilha de São Tomé. Lisboa: Junta de Investigações do Ultramar, 1961. p. 69.
} 
autoridades e seus respectivos partidos, com relativos prejuízos para o desenvolvimento do território. Este desentendimento e falta de disciplina bem como os ataques de franceses e holandeses nos finais do século XVI, e até algumas insurreições, como a dos angolanos, em 1574, só debelada em 1639, pelo governador Pereira Barredo, arruinaram completamente a indústria açucareira das ilhas, terminado assim o que podemos classificar como primeiro período de exploração agrícola de São Tomé ${ }^{142}$. Fatores de ordem interna, política e administrativas, não permitiam suster a ruína que desabou subitamente sobre moradores da ilha. Dente eles avultam os ataques e pilhagens dos angolanos. Os angolanos, nada se sabem quanto ao número, nem data exata em que atingiram a terra, somente é possível afirmar que vieram de Angola, oriundo de algum tipo do litoral do norte, que se chamava a si próprio, Ngolá (não Ngola); a expressiva acentuação do à final explicará a fixação da forma angolar e angola, angolano ou angolense, como seria mais correto ${ }^{143}$. Acrescenta-se a estas calamidades de ordem interna, como a revolta dos angolanos e desmandos entre forças governamentais, tendo os ataques a partir de 1567, a ilha também sofreu ataques armados mais ou menos organizados de países estrangeiros. Logo naquele ano, os consórcios franceses que vinham incomodando os domínios portugueses, pelo menos desde a segunda metade do século XV, a coberto da nossa deficiência em navios, atacaram a cidade de São Tomé, provocando distúrbios vários. Mas dolorosos para a vida da ilha foram ataques holandeses. Em 1599 ou em 1600 uma esquadra ataca a cidade de São Tomé, que é saqueada ${ }^{144}$. Uma situação que veio a agravar mais a situação da economia açucareira e da ilha como um todo foi à desorganização e instabilidade reinantes entre os governantes, bispos, ouvidores gerais e juízes do direito. As principais forças vivas do país lutavam entre si pelo mando e pela riqueza.

No final do século XVI a situação ficou mais complicada e a desordem entre os principais representantes do país levou o monarca português e o papa a tomarem medidas severas ${ }^{145}$. De certo modo, tais instabilidades, a meu ver, puseram em causa a soberania da ilha, uma vez que, já havia nessa época vários outros problemas

\footnotetext{
142 AGÊnCIA GERAL DO UlTRAMAR (Portugal). São Tomé e Príncipe: pequena monografia. Lisboa: Agência Geral do Ultramar, 1969. p. 39.

${ }^{143}$ TENREIRO, Francisco. A Ilha de São Tomé. Lisboa: Junta de Investigações do Ultramar, 1961. p. 72.

144 Ibid., 74.

145 TENREIRO, Francisco. A Ilha de São Tomé. Lisboa: Junta de Investigações do Ultramar, 1961. p. 73.
} 
vivenciados pelo país, e este fato deixou um maior estado de vulnerabilidade de poder de atuação, frente a qualquer outra força.

Em 1578, tudo indica que a indústria açucareira estava em franco declínio por conta das instabilidades reinante na ilha, que destruiu os canaviais. Antes disso, a ilha teria chegado a exportar anualmente quarenta naus grossas de açúcar, isto é, umas 800.000 arrobas, sendo que cada nau grossa carregasse 20.000 arrobas, mas depois dos ataques, a exportação teria baixado para cinco a seis naus grossas, por ano, ou seja, aproximadamente 120.000 arrobas. Provavelmente essas cifras poderiam ser bem maiores, pois os dados são baseados nas taxas cobradas pela coroa e na época, havia um número elevado de sonegação de impostos ${ }^{146}$. Muitos dos colonos que se dirigiam para as ilhas intencionavam de alguma maneira em ficarem ricos, as terras eram dadas no sistema de sesmaria. Apesar de São Tomé ter apresentado boas condições para o plantio da cana, não havia nenhuma garantia por parte desses colonos nos retornos dos investimentos ali feitos. As taxas eram cobradas muito antes da colheita e isso, de alguma forma desestimulava o agricultor na quitação de tais taxas. A sonegação das taxas era muito alta, que muitas das vezes, as terras eram tomadas pelo próprio rei e revendidas para outros interessados ${ }^{147}$. As cobranças das taxas eram constantes, não obstantes, como os interesses dos contratadores das terras estavam acima de qualquer situação, as dívidas continuavam por todas as ilhas ${ }^{148}$. Posto isso, acredita-se que a produção açucareira em São Tomé, provavelmente tenha chegado à cifra de 1.000.000 de arrobas, pois os cálculos das produções até aqui calculados eram baseados nas taxas cobradas pelos mesmos contratadores de terras, que pelos vistos as sonegavam muito. Alberto Vieira já havia destacado, que no momento de auge de açúcar em São Tomé, o número dos engenhos ali instalados chegariam a quatrocentos, o que resultaria em uma

\footnotetext{
${ }^{146}$ PT/ANTT/CC/1/73/118. *Carta de Diogo Soares, tesoureiro dos defuntos da Guiné, dando parte a D. João III que nas ilhas de São Tomé havia muito dinheiro e fazendas sonegadas pertencentes aos mortos. Corpo Cronológico, 1553, Parte I, mç. 73, n. ${ }^{\circ} 118$.

147 A.H.U., São Tomé. [post. 1595, Abril, 24], Requerimento do [contratador das ilhas dos Açores], Cristóvão Pais, ao rei [D. Filipe I] solicitando que a sua causa fosse remetida a Francisco Giraldi ou a outro de seu serviço, para que o procurador da Fazenda Real concluísse a liquidação da sua conta, em virtude de, há doze anos, ter sido preso e a sua fazenda de pastel, trigo e açúcares vendida, em São Tomé e nas ilhas de Seis mil, e apesar de mandado libertar por D. Sebastião, não se procedera à liquidação da conta. Obs.: m. est.; doc. cosido; anexo: requerimento. cx. 1, doc. 2.

${ }^{148}$ AHU-São Tomé. [post. 1602, Novembro, 29] Requerimento dos contratadores do trato da ilha de São Tomé, ao rei [D. Filipe II] solicitando o pagamento dos direitos que lhes deviam ter sido pagos na feitoria da ilha quando da saída dos açúcares, tendo eles feito petição ao alcaide-mor. Obs.: m. est.; doc. cosido; anexo: instrumento em pública forma. cx. 1, doc. 7.
} 
produção muito elevada ${ }^{149}$. Para Lains e Silva, a ilha de São Tomé teria alcançado anualmente quarenta naus grossas de açúcar, o que gerava em torno de 800.000 arrobas, considerando que cada um desses barcos carregasse 20.000 arrobas e essas altas sofre declínio conta dos ataques dos Barcos dos estrangeiros e até mesmo dos forros, fazendo a reduzir a produção ${ }^{150}$. A produção não declinou definitivamente, anos após os ataques, Frutuoso Ribeiro nos adverte, em das suas cartas que passava ao padre Francisco Mariz, datada de 14 de março de 1580, em que relata a sua viagem de Lisboa, de onde partiu em outubro de 1579 para Luanda, onde chegou em fevereiro de 1580, se infere que a produção de açúcar em São Tomé seria de 200.000 arrobas ${ }^{151}$. Mas essa prosperidade não haveria de durar por muito tempo.

Entre 1589 e 1592, enquanto Gaspar Cadena ocupava o cargo de recebedor de São João, a Coroa produzia aproximadamente 63.309 arrobas de açúcar, e vinte anos mais tarde, não produziam mais de 60.000. Em 1636, a produção de açúcar era apenas de 20.000 arrobas, daí em diante a indústria poderia se considerar arruinada ${ }^{152}$. Difícil seria de afirmar com certa exatidão quando se deu a decadência da produção açucareira em São Tomé e quais as principais causas que levaram a tal decadência. Para se ter uma ideias dos fatos, foram inúmeros ataques, desde o início da produção até a sua decadência: revolta dos angolanos, ataques dos franceses, dos holandeses, cada um se processou em época diferente, devastando grande parte da produção, se sabe que o período seguinte as plantações eram repostas e produção retomada, fazendo com que a produção se mantivesse em grandes proporções. Seria impraticável afirmar ainda que a decadência do açúcar se deu por conta da entrada da produção brasileira no cenário, nem tão pouco afirmar que as principais causas foram as invasões/ataques nacionais ou

149 Alberto Vieira destaca que em momentos de auge do açúcar, o número de engenhos instalados em São Tomé chegaria em 400 e esse número só veio a declinar por conta das instabilidades políticas, as revoltas dos angolanos e as invasões dos barcos estrangeiros, nomeadamente holandês de franceses. Ver: VIEIRA, Alberto. Portugal y las islas del Atlántico. Madrid: Editorial MAPFRE, 1992. p. 168.

${ }^{150}$ LAINS E SILVA, Hélder. São Tomé e Príncipe e a cultura do café. Lisboa: Junta de Investigações do Ultramar, 1958. p. 85.

${ }^{151} \mathrm{O}$ relato mostra a reviravolta da produção açucareira no final do século XVI. Ela declina e volta a crescer quando a situação acalma. Ver: LOPES, Duarte; PIGAFETTA, Filippo. Relação do reino de Congo e das terras circunvizinhas. Tradução de Rosa Capeans. Lisboa: Agência Geral do Ultramar, 1951. Mas a estabilidade econômica não foi fixada, posto que a ilha de São Tomé passava por inúmeros problemas que afetaria direta ou indiretamente a situação da produtividade. Uma delas é talvez a fundamental: a instabilidade política reinante na luta pelo poder entre vários órgãos representativo do país. Ver: LAINS E SILVA, Hélder. São Tomé e Príncipe e a cultura do café. Lisboa: Junta de Investigações do Ultramar, 1958. p. 84.

${ }^{152}$ LAINS E SILVA, Hélder. São Tomé e Príncipe e a cultura do café. Lisboa: Junta de Investigações do Ultramar, 1958. p. 85. 
estrangeiras, afirmar que a causa estaria nas desorganizações internas ou na má qualidade do açúcar produzido em São Tomé.

Primeiro quando entra no cenário a produção do açúcar brasileiro, São Tomé continua produzindo açúcar, ainda que seja em uma proporção relativamente menor, mas o que queremos aqui destacar é que São Tomé possuía terras férteis e de boa qualidade, simplesmente, quando se encontra uma terra boa, igualmente e de boa qualidade, não se abandona a primeira em função da segunda. Por outro lado, embora o Brasil possuísse terras boas e de grande qualidade, por ali se vivia problema de escassez de mão de obra, o que para São Tomé já eram problemas resolvidos, devido ao entreposto de escravos ali instalado. Relativo ao açúcar de péssima qualidade produzido nas terras santomenses na época colonial existe uma possibilidade, porém nada leva crer que isso de fato procedeu, pois todos os argumentos se traduzem ao preço inferior do produto praticado naquela região. Se só levarmos em consideração o fato que o açúcar de São Tomé vendia-se a um preço menor no mercado para alegar a sua qualidade era inferior, no mundo atual, isso não necessariamente enquadraria. Sabe-se que muitos bens vendem a preço baixo pelo foto de possuir um custo de produção (mão de obra, matéria prima; equipamento para trabalho, etc.,) menor, e isso é perfeitamente razoável quesito do mercado no que se refere à lei dos custos, por outro lado, o preço de um determinado bem pode cair quando o mesmo tem um oferta muito elástica e o seu produtor querer se desfazer dos estoque para renovar os produtos. Parece que em São Tomé ocorreu algo parecido, pois possuia terras férteis em abundância, clima favorável e uma reserva de mão de obra muito grande, o veio a dinamizar sistema produtivo nesta região de tal forma que a produção média local estaria muito acima da média produzida nas olhas ilhas. Por outro lado, se o açúcar de São Tomé fosse de tão péssima qualidade assim, os seus produtores não insistiriam duram séculos nesta região, uma vez que poderiam deslocar para outras regiões como forma de produzirem um produto de melhor qualidade. Quando a produção açucareira de São Tomé entra em cena, faz cair a produção de ilha de Madeira, uma ilha que até aquele momento, seria a maior e melhor produtora deste artigo, certamente a mesma não perderia espaço no mercado para um produto de inferior qualidade.

Alberto Viera mostra-nos que a queda da produção açucareira na ilha da Madeira, começa a partir do momento que se começar a produzir este produto em São Tomé. Este novo espaço do Atlântico em 1517 já se produzia aproximadamente 
100.000 arrobas de açúcar, um valor que superaria a produção madeirense no período, que girava em torno de 93.000 arrobas $^{153}$. Estima-se que vinham técnicos especializados da ilha da Madeira, com tecnologias capaz que fazer um açúcar melhor, logo fica difícil afirmar que o açúcar poderia ser de péssima qualidade em São Tomé. Como destaca Alberto Vieira:

Mayor era La dicultad para secarlos penesde azucar, debido a La elevadahumedad de aire. Por ello fue necesario definirun métudo capaz de conseguirlo em poço tiempo (...). Las más antigua referenciaa los ingenios de agua em La islã data de 1517 , fecha en que La producción de la isla rondaría las 100.000 arrobas. Estos valoresprueban que en poco tiempo São Tomé suplantó a Madeira, que producía 93.000 arrobas y nunca subpasaría la barrera de la 144.000 arrobas, conseguidas em 1510. En São Tomé lãs plantaciones de cañaverales producían mucho más, de modo que en 1520 la cosecha sobrepasó lá 120.000 arrobas, para alcanzar, en lãs décadas de las cuarenta a sesenta las 150.000 . en este período El número de ingenios llegaria a los cuatrocientos ${ }^{154}$.

No texto acima, fica muito claro que a queda da produção açucareira madeirense estaria relacionada ao começo da produção em São Tomé, é provável haja outros motivos, mas até o presente, tudo leva a crer que motivos são esses. E se assim for, isso estaria provando o contrário. O açúcar de São Tomé, certamente seria um dos açúcares mais cobiçados e procurados no mercado internacional, uma vez que ele começa a ser produzido e tira os espaços de antigos engenhos.

${ }^{153}$ VIEIRA, Alberto. Portugal y las islas del Atlántico. Madrid: Editorial MAPFRE, 1992. p. 168.
${ }^{154}$ VIEIRA, Alberto. Portugal y las islas del Atlántico. Madrid: Editorial MAPFRE, 1992. p. 168. 


\section{CAPÍtulo II}

\section{2 - Fatores pertinentes para o êxito da economia açucareira em São Tomé e Príncipe.}

Conforme apresentado anteriormente, tão logo as ilhas de São Tomé e Príncipe foram descobertas pelos portugueses passaram a produção de açúcar. Neste capítulo, serão apresentados os motivos pelos quais a indústria açucareira obteve sucesso na região.

Inicialmente, acredita-se que a introdução da cana-de-açúcar e a produção nas ilhas do Atlântico, se originou em consequência, da não adaptação dos cereais e outros produtos que demandava o comércio europeu. No final do século XIV e início do século seguinte, Portugal vivia numa crise de subsistência. A escassez de cereais foi o centro motivador da crise, que desde o reino de dom Afonso III, já se fazia sentir ${ }^{155}$. Não havia nenhuma saída interna para Portugal, um país onde se dependia fortemente da agricultura, começou a se criar fortes problemas com as cheias, nas regiões onde se podia cultivar. Boa parte do solo português, aproximadamente dois terços, é demasiadamente rochoso, íngreme ou pedregoso para serem cultivados, ou então o solo é tão pobre que produz colheitas incertas. Além disso, havia ainda nesta época, em Portugal, extrema irregularidade de chuvas e com uma precipitação imoderada, dificultando a agricultura ${ }^{156}$. Portugal e muitos países europeus tinham como fonte comercial de abastecimentos de produtos, a Índia, numa época de possessão turca do Levante substituiria a civilização mercantil árabe por uma civilização guerreia, abrindo um dos problemas da história mundial, cortando as vias comerciais entre a Índia e a Europa $^{157}$. Sabe-se que o açúcar, antes da sua entrada nas ilhas do Atlântico, era produzido pelos venezianos e genoveses, do qual detinham o monopólio. A economia insular Atlântica, em particular, com o de açúcar, ganha força quando os produtores e os maiores fornecedores para o mercado europeu entram em instabilidade. A sorte de

\footnotetext{
155 GODINHO, Vitoriano Magalhães. A expansão quatrocentista portuguesa: problemas das origens e da linha da evolução. Lisboa: Empresa Contemporânea de Edições, 1942. p. 9.

156 BOXER, Charles Ralph. O império marítimo português, 1415-1485. Tradução de Anna Olga de Barros Barreto. São Paulo: Companhia das Letras, 2002. p. 18.

${ }^{157}$ GODINHO, Vitoriano Magalhães. A expansão quatrocentista portuguesa: problemas das origens e da linha da evolução. Lisboa: Empresa Contemporânea de Edições, 1942. p. 9.
} 
Portugal é que as novas terras descobertas no Atlântico ofereciam boas condições, o que fez viabilizar tais instalações. Na verdade, a grosso modo, essa economia nasce em duas vertentes, sendo a primeira, na queda ou enfraquecimento dos maiores produtores e fornecedores do açúcar no mercado europeu e os fatores internos das ilhas condicionantes. A esses fatores pode-se destacar: localização privilegiada, abundância de mão de obra, experiência técnica trazidas pelos mestres do açúcar madeirenses e outros mestres (venezianos e genoveses), clima favorável e a fertilidade da terra. Além desses fatores, existem outros como: abundância de lembra e lenha, o valor e a procura do produto (açúcar) no mercado internacional que de certa forma proporcionou e viabilizou tais êxitos.

\subsection{Localização privilegiada}

Com o contato com os habitantes naturais dessas ilhas, certamente ficaria muito mais fácil entender o privilégio da sua localização e o que a mesma poderia proporcionar para alguém que se dirigisse para ali com intuito e espírito agroindustrial. São Tomé e Príncipe pode-se dizer que se situam no centro do mundo, onde existem imensas facilidades de conexão para outros países, basta possuir um meio de transporte adequado, para viajar para os quatro cantos do mundo. A Este do país encontra-se a costa africana e ao Norte, o continente Europeu e ao Oeste as Américas. O país também servia como entreposto, ou seja, durante muitos anos os escravos antes usados no trabalhado forçado, homens e mulheres capturados em diferentes regiões da áfrica, principalmente pelos colonos portugueses, eram encaminhados para essas ilhas, depois para serem distribuídos para outras regiões que os demandavam. Também nessas ilhas, servia como um ponto de descanso para os navegadores que quisessem atravessar o Atlântico para viajar mais longe, vindo da Índia ou outros países asiáticos, para as Américas ou mesmo dos países europeus, nada melhor que fazer uma paragem nessas ilhas, repousar e prosseguir mais descansado, com energia renovada. Outros privilégios estariam em condições fornecidas pelas ilhas, como abundância de água e facilidade de cultivo dos produtos para consumo local e para os viajantes, devido a fertilidade da terra e o clima favorável para o mesmo. De acordo com Silva ${ }^{158}$, o local escolhido

\footnotetext{
158 SILVA, Teresa Madeira da. A cidade de São Tomé no Quadro das Cidades Insulares Atlânticas de Origem Portuguesa. In: COLÓQUIO INTERNACIONAL SÃO TOMÉ E PRÍNCIPE NUMA PERSPECTIVA INTERDISCIPLINAR, DIACRÓNICA E SINCRÓNICA, 2012, Lisboa. Actas do Colóquio Internacional São Tomé e Príncipe numa perspectiva interdisciplinar, diacrónica e
} 
caracteriza-se por se localizar junto a uma baía abrigada, numa zona onde existiam boas condições para a criação de um porto natural e as condições topográficas permitiam facilmente a implantação de pontos de defesa. A proximidade de uma ou mais ribeiras constituía igualmente uma característica do local escolhido, uma vez que permitiam o abastecimento de água potável às populações. Deste modo, a proximidade de terras que servissem para o cultivo de produtos agrícolas, para a alimentação das populações e apoio aos navios constituía outra das características do local para a implantação do núcleo urbano de São Tomé.

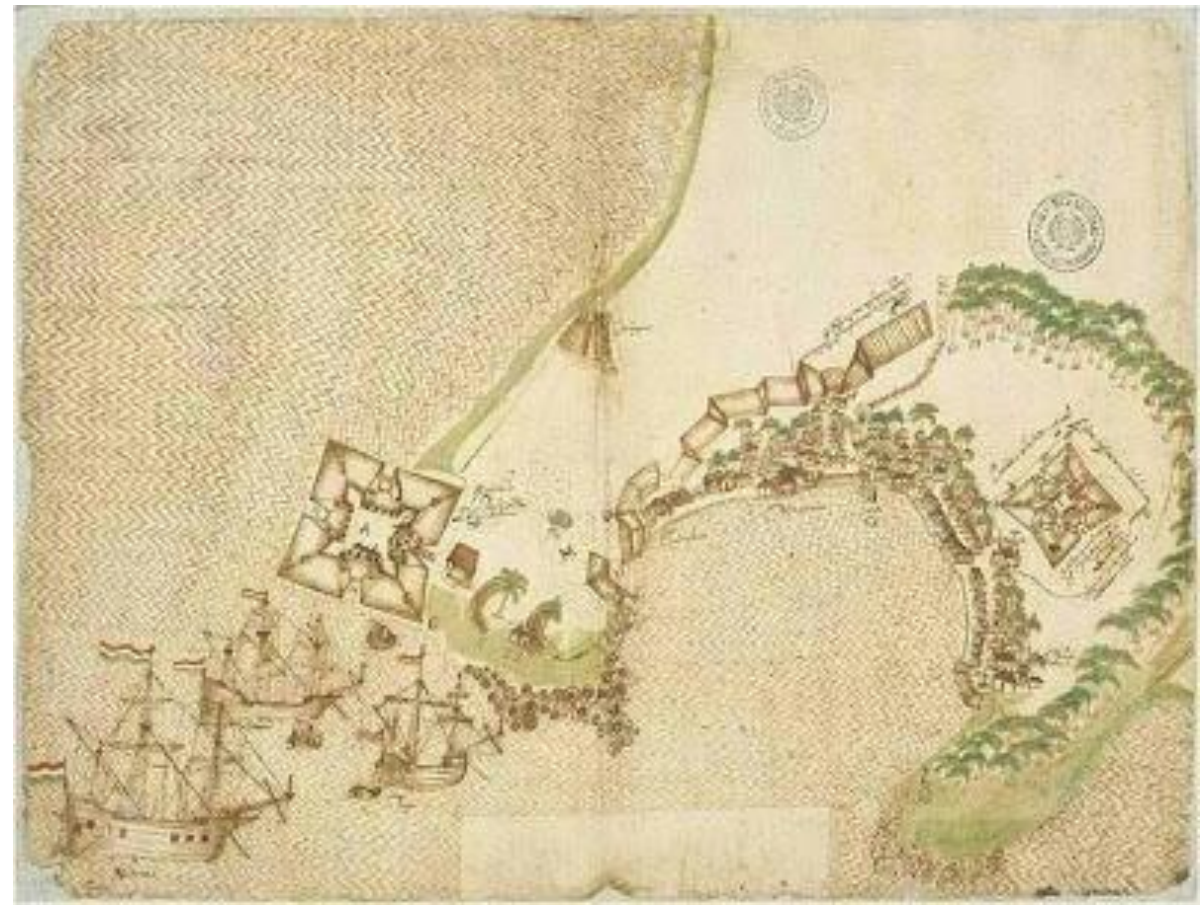

Figura 3: Baía de Anna de Chaves, constando a Cidade Capital, a Fortaleza de S. Sebastião e o Forte do Pico da nossa Senhora da Graça (1644).

Fonte: A.H.U. - Col. Cartografia Ms.- VII CM. No 170.

Na Baía de Anna Chaves existiam e ainda existem boas condições para a criação de um porto natural, o que facilitou tais aventuras. A topografia facilitava a implantação de pontos de defesa e a qualidade das terras proporcionava o cultivo de produtos agrícolas. Igualmente, a proximidade de uma ribeira (denominada na época de Ribeira Grande e hoje chamada do Rio de Água Grande), facilitava o abastecimento de água

sincrónica. Lisboa: Instituto Universitário de Lisboa, Centro de Estudos Africanos, Instituto de Investigação Científica Tropical, 2012. p. 49-71. 
potável às populações. É aceite que a coroa portuguesa recomendou, no início do povoamento, a introdução de várias culturas rentáveis nas diferentes ilhas Atlânticas. Segundo o piloto português, na época, devido tanto nevoeiro que se fazia, resultaria em curso de água que se formava em virtude da intensa condensação do mesmo, e perante isso, vê-se tanta quantidade de água, sendo cada lado do monte descem rios, uns maiores e outros menores. Com essas águas os trabalhadores, principalmente negros ali recrutados, regavam os campos onde estavam as canas-de-açúcar. E continua, o piloto português: existe também, em toda ilha muitas fontes de água corrente, de que servem para mesmo fim. Inclusive na cidade, naquela época, corria um regato de água claríssima, muito lagos, mas pouco fundo, na qual davam a beber os doentes porque eram muito leve $\mathrm{e}^{159}$.

Desde início ou após o descobrimento, as terras de São Tomé eram entregues aos colonos em sistemas de sesmarias, por cinco anos, na qual a principal meta desses seriam garantir a produtividade das terras recebidas. Assim que o prazo terminava, as terras ficavam na posse de quem a recebia, em conformidade com maior ou menor aproveitamento que lhes foram dados. $\mathrm{O}$ aparecimento da fazenda real era um fato, cujo objetivo era produção de alimentos para os escravos que eram recebidos nas ilhas, as esperas de serem enviados para outras paradas. Depois da indústria do açúcar florescente, essas terras também passaram a albergar as plantações de cana-de-açúcar bem como os engenhos ${ }^{160}$. Assim, nos anos 30 do século XVI, os engenhos ali instados já produziam 150 mil arrobas de açúcar, se levar em conta o conversor do Brasil e de Portugal $^{161}$, em que 1 arroba equivale a $15 \mathrm{~kg}$ (quinze quilogramas), logo daria,

\footnotetext{
${ }^{159}$ Loureiro, Rui. Navegação de Lisboa à Ilha de São Tomé: escrita por um piloto português. Lisboa: Grupo de trabalho de ministérios da educação para comemorações dos descobrimentos portugueses, 1989. 160 COSTA, José Domingos. João Menino - comerciante ou escravo? In: COLÓQUIO INTERNACIONAL SÃO TOMÉ E PRÍNCIPE NUMA PERSPECTIVA INTERDISCIPLINAR, DIACRÓNICA E SINCRÓNICA, 2012, Lisboa. Actas do Colóquio Internacional São Tomé e Príncipe numa perspectiva interdisciplinar, diacrónica e sincrónica. Lisboa: Instituto Universitário de Lisboa, Centro de Estudos Africanos, Instituto de Investigação Científica Tropical, 2012. p. 18.

${ }^{161}$ Como unidade de massa, a arroba equivale originalmente à quarta parte do quintal, isto é, 25 libras (aproximadamente $15 \mathrm{~kg}$ ). Porém, esse valor não foi sempre o único a ser utilizado, nem as libras equivaliam. No Reino Unido equivaliam a cerca de 50 libras (150 kg, e essa diferença se deve a diferença de massa entre a onça e o grama). Em Espanha, a arroba equivalia a 25 libras (11,502 kg) em Castela, a 26 libras (10,4 kg) na Catalunha e a 36 libras (12,5 kg) em Aragão. Em Portugal e no Brasil equivalia a 32 arráteis, o que equivale a 14,688 kg. Com a introdução do Sistema Internacional de Unidades, a arroba perdeu boa parte de sua função, mas ainda não deixou de existir. Ver: WIKIPEDIA. Disponível em: < https://pt.wikipedia.org/wiki/Arroba> Acesso em: 25 set. 2015.
} 
aproximadamente, hoje, 2.250.000,00 kg (dois mil, duzentos e cinquenta quilogramas), equivalente a 2.250 toneladas (duas mil e duzentos e cinquenta toneladas).

A facilidade e condições proporcionadas pelas terras facilitaram a alimentação e o modo de viver de quem por lá fosse. Em São Tomé e Príncipe existiram e ainda existe uma imensidão de terras férteis e uma abundante vegetação, isso faz combinar com uma vasta variedade de frutas, peixes e tubérculos. Os peixes, devido a sua abundância, poderiam ser pescados ou capturados com uma rede a beira-mar, e durante a colonização dessas ilhas, as espécies ali existentes eram muito apreciadas. Por ali também existia uma variedade de tubérculos usados nas refeições. Os melhores pratos e os mais consumidos no país são feitos na base de legumes e peixes. O calulú é um prato tradicional muito apreciado por famílias são-tomenses que se assemelha a uma sopa a base de peixe seco ou carne, come-se acompanhado de banana pisada no pilão (angú), fruta pão e ou fubá mexido. Cachupa outro prato tradicional do país, embora com origem cabo-verdiana, inclui ingredientes cozinhados como peixe, milho e feijão. Muzengué, também um prato tradicional, é preparado com peixe fumado (peixe seco ao fumo), fruta-pão, óleo de palma, cebola e especiarias. Em termos gerais, a cozinha sãotomense é muito rica em proteína vegetal e marinha. Os produtos que são resgatados do mar, desde muito cedo (após a descoberta das ilhas) constituíram componentes fundamentais dos hábitos alimentares em São Tomé e Príncipe. Os animais marinhos mais conhecidos e consumidos são: barracuda, espadarte, peixe-voador, corvina e garoupa, xoco, polvo, peixe-caque, tubarão, masponbo, lagosta, camarão e outras iguarias. As frutas locais são usadas na alimentação e existem algumas delas que são específicas e exclusivas do país, por exemplo, temos o safú, a cajá-manga, o guêgui, etc. Muitas das frutas são usadas nas confecções das refeições, exemplo prático seria o Caril que feito na base de cajá-manga, cenoura e carne. Além de uso das frutas no preparo das refeições, as frutas também são usadas nas confecções de doces, bem como para fazer sucos.

A raiz a que os índios da ilha Espanhola chamam batata, os habitantes de São Tomé chamam de inhame, e cultivam como sendo o seu principal sustento (o piloto português confunde batata com inhame). É de cor negra na casca de fora, mas por dentro é branca, e é do tamanho de um grande nabo, como muitas ramificações. Comem-na assada de baixo de cinzas, também cozida. Existem diversas espécies dessas raízes, isto é, inhame chicoreiro, o qual os navios que vem para São Tomé carregar 
açúcar levam em grandes quantidades, para se sustentar no mar. Os mesmos mantêm fresco durante muitos meses(motivo de sua expressiva plantação), até mesmo um ano sem estragar. Há mais três espécies do dito inhame, isto é, do Benim, do Manicongo e o amarelo, mas esses não duram muito tempo. O do Benim tem um gosto mais delicado que qualquer dos outros. Os negros plantam bastante, porque os navios levam muitos. Tudo leva a crer que esse tipo de inhame fosse muito consumido e produzido também devido a sua facilidade de cultivo: o modo de plantar consiste em cortar as talhadas, tirando um pedaço de casca em cada uma, e plantam as talhadas, retirando as ervas. Ao pé, introduzem uma vara comprida, a fim de que quando o inhame nasça se vá enrolando em volta da pequena vara, como se fosse o lúpulo. Havia também milho zaburro, vindo do continente, que dava várias colheitas ao ano, além disso, também havia bananeira e a palmeira que tiveram grande importância na alimentação dos residentes, principalmente dos escravos. Também, outros produtos tiverem participação nas dietas alimentares dos colonos, como as hortaliças, tais como: alfaces, couve, rábanos, beterraba, cebolas, alhos, melões e abóbora ${ }^{162}$.

\subsection{Abundância de mão de obra.}

O comércio de escravos teve grande contribuição e participação na produção açucareira em São Tomé e que sem esta, a produção não teria conhecido grandes prosperidades. Após a descoberta, São Tomé, sem mesmo introduzir a cana-de-açúcar, com os donatários João de Paiva e Álvaro de Coimbra, chegaram os primeiros povoadores. Nesta época por lá já se encontrava população portuguesa proveniente da metrópole e da Madeira, descendentes de judeus que tinham ido com Álvaro Coimbra, muitos castelhanos, franceses e genoveses, e africanos (negros) de diferentes regiões africanas $^{163}$. Havia uma política na época, de atrair maior número possível de colonos, facilitando a residência a todos os que quisessem ir habitar na ilha. Como enfatiza Tenreiro $^{164}$, os povoadores por lá instalados, dedicavam-se fundamentalmente a

\footnotetext{
${ }^{162}$ COSTA, José Domingos. João Menino - comerciante ou escravo? In: COLÓQUIO INTERNACIONAL SÃO TOMÉ E PRÍNCIPE NUMA PERSPECTIVA INTERDISCIPLINAR, DIACRÓNICA E SINCRÓNICA, 2012, Lisboa. Actas do Colóquio Internacional São Tomé e Príncipe numa perspectiva interdisciplinar, diacrónica e sincrónica. Lisboa: Instituto Universitário de Lisboa, Centro de Estudos Africanos, Instituto de Investigação Científica Tropical, 2012. p. 17.

${ }^{163}$ BOXER, Charles Ralph. O império marítimo português, 1415-1485. Tradução de Anna Olga de Barros Barreto. São Paulo: Companhia das Letras, 2002.

${ }^{164}$ TENREIRO, Francisco. A Ilha de São Tomé. Lisboa: Junta de Investigações do Ultramar, 1961.
} 
atividade agrícola, comércio do açúcar e dos escravos. Interessante aqui destacar, que além dessas atividades, havia também outras atividades secundarias, como comércio de madeira, outras produções agrícolas secundarias (de subsistências), pesca etc., e colheita dos produtos da natureza, sendo essas dedicadas exclusivamente nas horas vagas dos trabalhadores. Nessas atividades secundarias as mais duras seguidas do trabalho na produção do açúcar estariam as cortes de madeiras, que seriam atividades muito difíceis e pesadas, sendo que antes do desenvolvimento da indústria açucareira começa-se com as exigências de combustível para suas fornalhas e secadores, além de madeiras para construção de casas e embarcações para enfrentar o mar alto, e acudir os pedidos da metrópole.

O trabalho árduo começa, na verdade, desde a descoberta da ilha e da sua ocupação, quando se começa a destruição da mata virgem ${ }^{165}$. Das madeiras mais utilizadas estariam pau azeitona: cuja madeira de imensa densidade, é incorruptível e ótima para construção naval; a socopira, pau moandim, ou bágea (Pentaclethra macrophylla): muito usada para liames, para construção da roda de proa, cadaste, gio, grinalda, dormentes e sicordas dos navios e de casas; o pau gogó (Sorindeia grandefolia): fornecedor de tabuado para navio e madeiras para moveis; o ocá (Ceiba pentandra): de que se fazem enormes navios escavados; o pau-caixão (Urophyllum floribundum): que seria a principal matéria prima que os angolanos até hoje ainda fazem as tábuas peralto, cortadas a manchim e à cunha e destinadas à construção de casas; pau quime (Newboldias laevis); pau-gamela (Banbax sp.); o pau gofe (Musanga cecropioides); o pau-ferro (Copaifera mopane): sofreram grandes corte no início da colonização da ilha ${ }^{166}$. A extração de madeira era essencial e o trabalho para seu corte e adequação era árduo e envolvia um contingente grande de pessoas.

É importante lembrar que os trabalhadores precisavam trabalhar também para tirar seu próprio sustento da terra, o cultivo de cana-de-açúcar era feito em paralelo com cultivo de alimentos. Em 1502 cultiva-se em São Tomé o milho zaburro (Zea mays), esse anteriormente importado da Guiné. Semeava-se e colhia ano todo, atendo as boas condições climáticas da região, possibilitava ocupar boa parte da terra. Certamente as terras planas eram as preferidas, que mantinham em sazão, mesmo em tempo seco. $\mathrm{O}$

\footnotetext{
${ }^{165}$ LAINS E SILVA, Hélder. São Tomé e Príncipe e a cultura do café. Lisboa: Junta de Investigações do Ultramar, 1958. p. 75.

${ }^{166}$ Ibid., p. 76.
} 
ciclo produtivo do milho era de três a quaro meses e quem diga (alguns observadores como piloto anônimo português) que ao fim de quarenta dias o milho amadurava. Da farinha do milho faziam pão e bolos cozidos debaixo de cinzas.

Boxer $^{167}$, aponta que desde as primeiras viagens do descobrimento e comércio, ao longo da costa da Guiné, escravos, ouro e marfim eram os bens primários procurados pelos portugueses. Primeiro a Ilha de Santiago de Cabo Verde e depois São Tomé, tornam-se depósitos de escravos, onde os escravos de alta e baixa Guiné eram reunidos e armazenados enquanto aguardavam o seu despacho. Na direção oposta, os portugueses (brancos e mulatos) viajavam de Cabo Verde e de São Tomé para alta e baixa Guiné, para resgate de escravo, ouro e marfim.

A questão que se verifica aqui seria, uma vez que a ilha de São Tomé, após a sua descoberta, funcionava como um entreposto de escravos, isso veio a facilitar, a produção açucareira em escala. Diferentemente dos outros países produtores do açúcar tais como: Ilha da Madeira, Açores, Brasil e as Antilhas, que no momento de auge da produção açucareira tiveram que recrutar ou comprar volumosos números de escravos para suprir mão de obra que se fazia sentir na época, essa ilha do Atlântico (São Tomé) havia um número grande dessa mão de obra, a medida que crescia a necessidade de uso dos mesmos.

\section{3 - O valor e a procura do açúcar no mercado internacional}

Conforme citado anteriormente, o açúcar tornou-se mercadoria de grande valor, seja quando tratado como medicação ou como alimento. Sua produção se deu por diferentes países e mesmo continentes representando um importante elemento de transformação do mundo moderno.

Uma situação intrigante é que nesse processo de valoração e posteriormente a procura deste bem no mercado internacional teve grande importância, pelo menos para o início do processo. Se por um lado o valor do produto (preço alto) veio a proporcionar ou estimular as instalações iniciais, por outro lado, a queda do preço veio a ampliar e expandir o processo produtivo. Já se viu que por volta de século XIV, o mais apreciado para adoçar os produtos era o mel ao invés do açúcar, pois este segundo era pouco

${ }^{167}$ BOXER, Charles Ralph. Relações raciais no Império colonial português: 1415-1825. Porto: Afrontamento, 1988. p. 14 
conhecido e o seu valor era altíssimo. Mas se um fator que facilitou a disseminação do açúcar é a descoberta de metais precisos em grande quantidade e seu uso como meio de troca, pois antes disso, muitos produtos eram adquiridos via troca direta, o que impossibilitava tais dinâmicas. Nessa época, entre 1383 e 1435, quando aflora a produção açucareira portuguesa, a economia ainda era baseada na troca, exceto valores dos impostos recolhidos e renda de terra era feito em dinheiro. Ainda não se cunhavam moedas de ouro em Portugal, embora houvesse circulação livre de moedas de ouro estrangeiras, além de guerras constantes com Castela que desvalorizava a moeda ${ }^{168}$. Por outro lado, o estímulo para a circulação do açúcar foi à necessidade de suprir as carências de alguns mercados europeus, em substituição do oriental, cada vez mais de difícil acesso $^{169}$. Essa situação facilitou de certa forma, uma conjuntura que viesse a impor essa cultura na região do Atlântico e que veio a ditar as regras do seu mercado. $\mathrm{O}$ que houve na verdade, foi um conjunto de hábitos, que foram sendo exigidos por conta de escassez de outros produtos que antes eram consumidos, forçando o mercado a criar novos hábitos e isto incluiria o açúcar.

Estima-se que com a entrada das ilhas do Atlântico no cenário açucareiro fez expandir muito a sua oferta e consequentemente o seu consumo. Nesta análise, vamos considerar a ilha da Madeira, que foi de início a primeira ilha descoberta, e a região seria a primeira que produzia o açúcar. Portanto, para entender o quanto a produção de açúcar se expandia, tomaria o caso da ilha da Madeira, que volta de 1470, anos após da sua descoberta, já produzia aproximadamente 20.000 arrobas e essa cifra mais que quintuplicou em 15 anos, ou seja, por volta de 1495, a mesma produção atingiria os 105.000, mais de $500 \%$ (mais precisamente um aumento de $525 \%$ ) $^{170}$. No final do século XV até o início do próximo, pelo menos na ilha da Madeira, em certa medida, a produção deste produto não aumentaria tanto quando se observou no início da produção, ou seja, houve um aumento em velocidade decrescente, um resultado de surgimento de várias outras regiões produzindo o açúcar. Se em 15 anos a produção deste bem havia

\footnotetext{
${ }^{168}$ Ver: BOXER, Charles Ralph. O império marítimo português, 1415- 1485. Tradução de Anna Olga de Barros Barreto. São Paulo: Companhia das Letras, 2002. p. 19.

${ }^{169}$ VIEIRA, Alberto. O Açúcar na Madeira: produção e comércio nos séculos XV a XVII. In: Producción y comercio del azúcar de caña en época pré-industrial. Actas del Tercer Seminario Internacional. Granada: Diputación Provincial de Granada, 1993. p. 50.

170 Acredita-se que embora houvesse uma diminuição na quantidade produzida, isso não veio a desestimular a sua produção, pelo contrário, o estímulo foi muito maior, considerando que mais e mais consumidores puderam ter acesso ao açúcar. MAGALHÃES, Joaquim Romero. O açúcar nas ilhas portuguesas do Atlântico séculos XV e XVI. Varia Historia, Belo Horizonte, v. 25, n. 41, p. 151-175, 2009. p.160.
} 
quintuplicado, como já foi observado, para os próximos 15 anos, a mesma subiria somente para 120.000 arrobas, uma cifra de aproximadamente de $114 \%$, uma redução muito grande, se considerarmos proporcionalmente o que já se vinha produzindo. No gráfico 1 ficaria mais claro, ao observar na inclinação da curva produtiva. Se observarmos no período de 1470 a 1495, a inclinação é muito mais ao vertical, pois neste período há uma maior aceleração do processo produtivo, agora se compararmos com o período de 1495 a 1510, vamos perceber que houve uma desaceleração em termos produtivos.

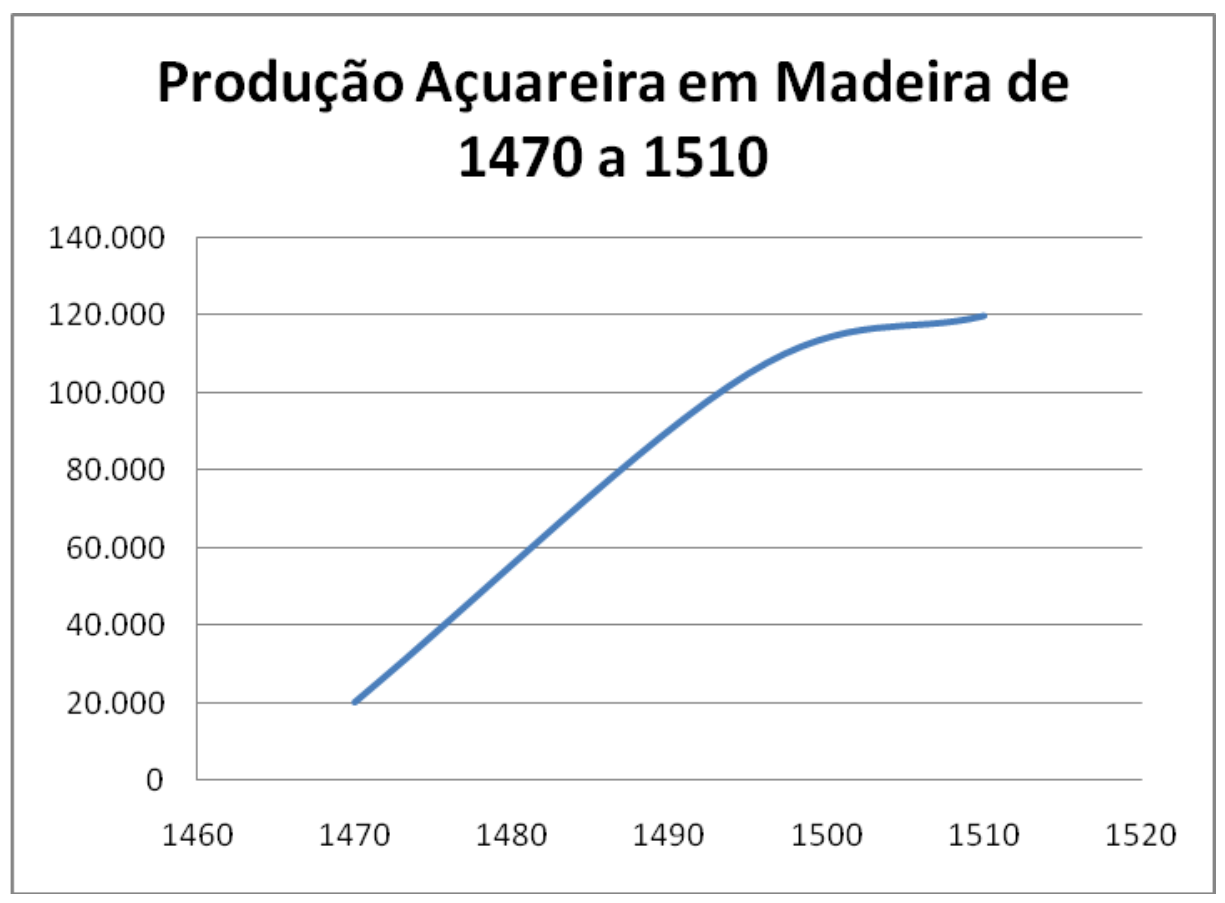

Grafico1: Produção Açucareira na Ilha da Madeira de 1470 - 1510.

Fonte: Quaresma, E.S.P $(2016)^{171}$.

O objetivo maior após a descoberta da ilha da Madeira era a implantação dos cereais, em particular o trigo, como já foi observado no capítulo anterior, um produto que representava a maior política da coroa portuguesa na época, por conta da escassez deste produto no reino. $\mathrm{O}$ açúcar entra em cena quando começou a haver desorganização em seus maiores produtores no mediterrâneo, produtores esses, que até o momento, faziam do açúcar um grande monopólio. Diante de tal situação, os

\footnotetext{
${ }^{171}$ Os dados utilizados na elaboração deste gráfico foram colhidos no trabalho "O açúcar nas ilhas portuguesas do Atlântico séculos XV e XVI" de Joaquim Romero Magalhães, citado na nota de rodapé anterior, o que, em certa medida, permite controvérsia. Mas é importante salientar que boa parte dos estudos relacionados à produção do açúcar na ilha Madeira, nessa época, indicam esses valores produtivos nos respectivos períodos.
} 
portugueses viram por bem introduzir o açúcar na ilha recém-descoberta, uma ilha que apresentava todas as condições necessárias para a produção deste bem. Por isso o sucesso foi imediato e não demorou muito tempo, para que encontrasse grandes prosperidades.

A perca do monopólio dos antigos produtores estimulou a produção em outras partes do mundo, que antes não tinham interesse em produzir o açúcar, o que levou muitos mercadores a levam o açúcar para vender no Mediterrâneo e, sobretudo no norte flamengo, fazendo concorrência aos produtores instalados em outras áreas. Com a nova entrada de grandes mercados neste processo, o preço do açúcar decaiu, dificultando em certa medida, sua produção. Isso fez inibir a produção na Madeira, pois no final do século XV para o começo do século seguinte, o açúcar de São Tomé, Açores, Canárias e Cabo Verde entra no mercado, fazendo reduzir o preço no mercado internacional deste bem. Neste período, muitos estrangeiros financiam a expansão dos canaviais, comprando o açúcar antes de produzido, dificultado ainda mais a situação do mercado, levando o preço para patamares bem menores do que já se encontravam. Para amenizar a situação, o senhorio, o infante dom Fernando, em 1469, cria um monopólio de mercadores de Lisboa para comprar toda a produção e lhe garantisse a manutenção dos preços, bem como, a renda dos mercadores. Apesar de tudo, a iniciativa não se concretizou, ou seja, ou não obteve sucesso, pois os moradores no Funchal - produtores ou não, todos interessados na produção e prosperidade da ilha - não consentem, o que levou o senhorio a instalar um processo de fiscalização complexo, calculado a partir de estimativas da produção de cada um dos lavradores, para conseguir assegurar a qualidade do açúcar e a estabilidade dos preços. Processo que se manteve durante alguns anos ${ }^{172}$.

O que se percebe até o presente momento, é que no início de todo o processo, a coroa portuguesa procurava um produto que tivesse grandes rendimentos. Na época havia vários produtos já conhecidos e produzidos por Portugal, tais como: trigo e vinho, porém os seus preços não eram tão atrativos e valorizados, capazes de gerar um rendimento tão grande, esperado pela coroa portuguesa. $\mathrm{O}$ açúcar era um produto raro e muito valorizado no mercado, ao ser produzido, fez gerar uma espécie de acumulação de riqueza, o que posteriormente, quando o preço do produto havia caído (aumento de

\footnotetext{
${ }^{172}$ MAGALHÃES, Joaquim Romero. O açúcar nas ilhas portuguesas do Atlântico séculos XV e XVI. Varia Historia, Belo Horizonte, v. 25, n. 41, p. 151-175, 2009. p.161.
} 
oferta), se pode implementar muitas fábricas. Essas indústrias produtoras do açúcar, embora com preço inferior ao que se praticava no início da instalação, vieram a sobreviver, pois poderia se produzir com um custo menor (devido mão de obra escrava) e um nível de produção muito maior (o produto passou a ser mais conhecido e consumido no mercado internacional), o que veio a garantir a estabilidade produtiva. Embora de início o preço do produto fosse maior, o que gerava um volume de lucro maior com poucas vendas, posteriormente devido aumento da oferta do produto, que se praticava em torno da produção de escala, com um preço muito menor, tudo leva a crer que o lucro do processo, nesta segunda fase (produção de escala com preço menor), fosse bem maior. 


\section{CAPÍTULO III}

\section{3 - Relação do processo produtivo em São Tomé com outras regiões do Atlântico.}

Neste capítulo pretendemos detalhar os fatores que viabilizaram a produção açucareira nas diferentes ilhas do Atlântico em sua relação com São Tomé e Príncipe. Depois da Ilha da Madeira, a Ilha de São Tomé foi a que mais mereceu atenção em termos de produção, nível de renda gerada, desenvolvimento técnico e mão de obra desenvolvida para produção açucareira, bem como fertilidade da terra, clima favorável e a localização estrategicamente viável, conforme já explicado. Em relação à produção açucareira, a Ilha de São Tomé, certamente se destacaria em primeiro plano, a partir do primeiro quartel do século XVI. Exceto a ilha da Madeira e de São Tomé, no Atlântico, nenhuma outra prosperou tanto quanto as citadas ilhas. Por isso São Tomé merece um tratamento diferenciado no contexto do espaço Atlântico, em termos de inovação tecnológica da produção açucareira e do desenvolvimento do processo.

Apesar de terem vindo muitos técnicos e tecnologias da ilha da Madeira, parece que em São Tomé se desenvolveu e aprimorou boa parte das tecnologias utilizadas na produção deste produto. Como mostra Alberto da Costa e Silva ${ }^{173}$, São Tomé foi um centro experimental na região do Atlântico, onde eram feitos ensaios com homens, plantas, formas de trabalho e fontes de lucros, e sem contar que era um lugar onde era possível unir na mesma categoria, proprietários de terra e comerciantes. Depois que essas técnicas foram desenvolvidas, regiões posteriores usufruíram com os principais proprietários e técnicos da ilha de São Tomé. A importância de São Tomé na inovação do processo produtivo açucareiro, vai muito além das questões estruturais, que favoreciam tais dinâmicas, no entanto, contribui ainda para o desenvolvimento e a expansão destes produtos nas regiões futuras. Enfatiza Schwartz ${ }^{174}$ que as mudas da cana-de-açúcar plantadas nas regiões de São Vicente até Pernambuco, no Brasil, foram trazidas da Madeira e principalmente de São Tomé ou ainda obtidas nas capitanias vizinhas. $\mathrm{O}$ autor destaca ainda a peculiaridade da ilha relativo ao crescimento de uma

\footnotetext{
${ }^{173}$ SILVA, Alberto da Costa. A manilha e o libambo: a África e a escravidão de 1500 a 1700. Rio de Janeiro: Nova Fronteira, 2002. p. 223.

${ }^{174}$ SCHWARTZ, Stuart. Segredos internos: engenhos e escravos na sociedade colonial. São Paulo: Companhia das Letras, 2005. p. 30.
} 
categoria de homens livres, os mulatos, que ocuparam posições importantes, o que em outras regiões isso não se processava. O clima tropical foi um diferencial em São Tomé, pelo baixo número de colonos em relação ao de escravos e igual ao de mulatos, e foi antecessor às muitas características que repercutiram no Caribe e no Brasil, como: sistema de grande lavoura, ou regime dos engenhos, havia amadurecido nas latitudes meridionais, e podia, agora, cruzar o Atlântico com trágica desenvoltura ${ }^{175}$. Tudo indica que antes dos portugueses se instalarem, a ilha estaria desabitada e, com isso, estaria assim aberta para qualquer um que a descobrisse, para impor suas iniciativas, implantar os produtos que mais demandassem no mercado internacional no período em destaque.

\section{1- A cana-de-açúcar}

Antes de entrar no tema, vamos tentar entender a planta em si. Por que outras plantas não possuem caracterizas parecidas? A cana-de-açúcar parece possuir a exclusividade na composição que a constitui. Para Fernandes, o açúcar nos vegetais resulta do fenômeno da fotossíntese. Para o autor, tudo começa nas folhas e na presença da luz solar, quando os grânulos verdes da clorofila absorvem calor e radiações ${ }^{176}$. Uma parte do açúcar assim produzido é consumida pelos próprios vegetais durante o seu crescimento e o restante é armazenado em alguma parte. Poucos são os vegetais como a cana-de-açúcar, a beterraba e o bordo que produzem e acumulam o açúcar sob forma de sacarose, enquanto a grande maioria o produz sob forma provisória de amido, antes de transformá-lo em glicose, outra parte em açúcar ${ }^{177}$. Para Galloway, estas plantas provem de regiões tropicais, adaptada ao clima quente e úmido, que seria o caso das ilhas do atlântico, em particular a de São Tomé, onde há uma boa quantidade de chuvas regulares e de bom sol, para que possa se desenvolver bem. Ao longo dos séculos esta matéria prima acabou se adaptando a distintos terrenos e tipos de solo, proliferando-se desde solos lamacentos na Ásia, até solos menos grossos e muito ricos em húmus nas Américas. A cana, dependendo da espécie, em geral são plantas finas, com hastes longas de onde brotam as folhas. Algumas dessas espécies chegam a ultrapassar quatro

\footnotetext{
${ }^{175}$ SCHWARTZ, Stuart. Segredos internos: engenhos e escravos na sociedade colonial. São Paulo: Companhia das Letras, 2005. p. 30.

${ }^{176}$ FERNANDES, Hamilton. Açúcar e Álcool, ontem e hoje. Coleção Canavieira, n. 4. Rio de Janeiro, Instituto do Açúcar e do Álcool, 1971, p. 14.

${ }^{177}$ Ibid., p. 14.
} 
metros de altura ${ }^{178}$. Tudo leva a crer que esta planta se adaptaria em qualquer região que tenha chuva em abundância, embora em algumas regiões com mais facilidade que outras, por conta da questão clima.

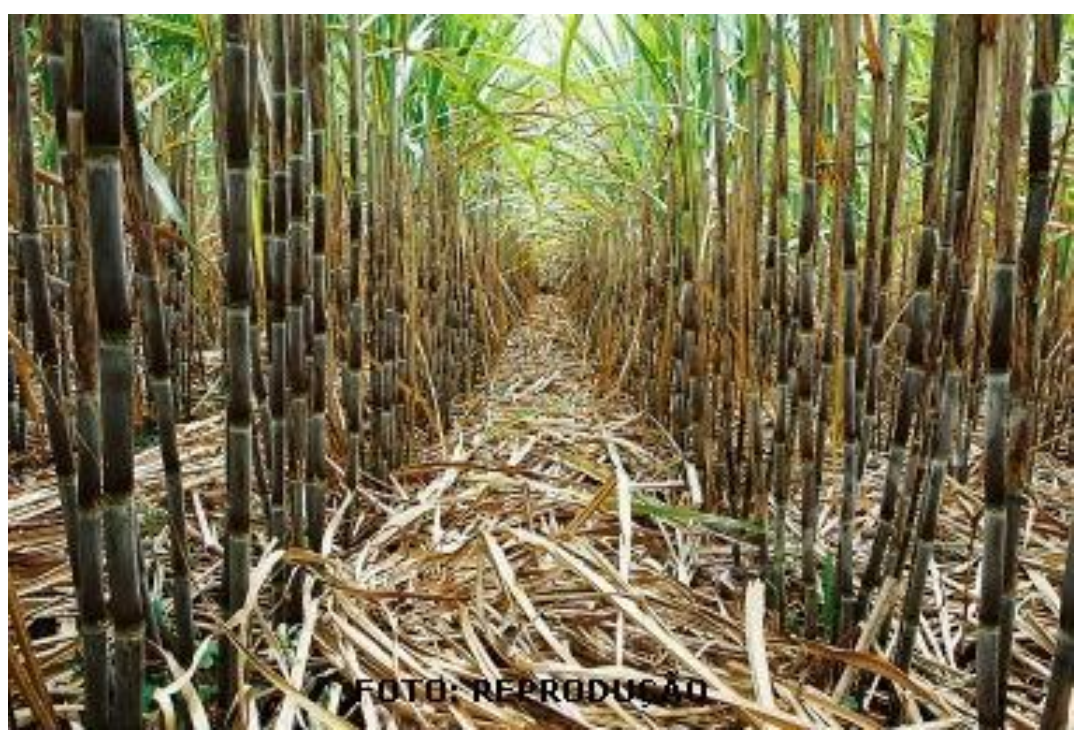

Figura 4: Uma Ilustração de Plantas de Cana-De-Açúcar.

Fonte: www.jaircorp1.wordpress.com (2011)

A cana-de-açúcar durante muito tempo fazia parte das pequenas plantações na região mediterrânea, mas a partir do momento que esta matéria prima conheceu alta de preço no mercado internacional verificou maiores interesses no mundo, além mediterrâneo. Tudo leva a crer que a cana sacarina foi um dos primeiros produtos que chegou à Europa e difundiu-se para as novas áreas de ocupação no Atlântico em maior proporção, posteriormente em outras regiões mais avantajadas como Brasil e Ilhas Caribenhas. A chegada da cana sacarina nas ilhas do atlântico foi um fenômeno muito inovador para o mundo, porque ela acelera as técnicas usadas, antes vindas do mediterrâneo, em formas muito mais dinâmicas, assim quando as possíveis subsequentes regiões fossem adotá-las, receberiam bem mais moldadas e avançadas. Não resta dúvida de que apesar dessas técnicas serem vindas do mediterrâneo, foi no Atlântico que ela constituiu o maior campo experimental, onde se ensaiam as mesmas técnicas e a estrutura socioeconômica, que será transplantada para as novas regiões fora do Atlântico produtor de açúcar. Esse processo fica mais claro com Galloway:

\footnotetext{
${ }^{178}$ GALLOWAY, J. H. The sugar cane industry: an historical geography from its origins to 1914 . New York: Cambridge University Press, 1989. p. 37.
} 
Madeira, the Azores and the other islands of the West African coast have long been regarded by historians as training grounds where the Spanish and Portuguese learnt lessons in colonial administration they later applied in the Americas. So it was also with the sugar industry. On these islands the colonists learnt to adapt their Mediterranean techniques of cultivation and production to cope both with unfamiliar environments and the ever larger scale of the industry, processes in which those initial characteristics of plantation agriculture first discernible in the Eastern Mediterranean became much more pronounced ${ }^{179}$.

$\mathrm{Na}$ região do Mediterrâneo, foram os italianos os primeiros a denotarem a importância da cultura sacarina e, consequentemente, o da sua produção, sendo os mesmos a dinamizarem a sua expansão na cristandade ocidental ${ }^{180}$. Para tanto, Vieira destaca que as primeiras sacas de cana sacarina que foram trazidas para a Madeira teriam vindo da Sicília, acompanhadas dos operários especializados, não obstante, estariam representantes desta cultura no reino, especificamente em Coimbra e no Algarves, bem como os mercadores italianos, nomeadamente genoveses, seguiram-lhe o rasto, foi quando a cultura se tornou importante na economia da região e começaram a surgir dificuldades com o comércio do açúcar oriental ${ }^{181}$. Na região do Atlântico, a sua produção começou na ilha da Madeira, mas não tardou muito para se estender para outras regiões. Embora nos primeiros anos, nas ilhas do Atlântico, a cana-de-açúcar, se apresentasse como um cultivo secundário, a partir dos meados do século XV já aparecia como um produto dominante nessas regiões, situação que perdurou todo o século seguinte ${ }^{182}$.

Devido algumas questões estruturais do próprio continente, como a necessidade de encontrar um produto que gerasse a renda de forma fácil e rápida, a cana-de-açúcar obteve, mediante essa situação, um grande apoio da coroa portuguesa para a sua implantação nas primeiras ilhas. Isso permitiu que a cana conquistasse facilmente o espaço Atlântico com muito mais rapidez que conquistou outros produtos ali implantados antes desta matéria prima, como vinho e cereais, que por infelicidade não obtiveram tanto sucesso quanto esta última. Além do sucesso, esta cultura trouxe um

\footnotetext{
${ }^{179}$ GALLOWAY, J. H. The sugar cane industry: an historical geography from its origins to 1914 . New York: Cambridge University Press, 1989. p. 48.

${ }^{180}$ VIEIRA, Alberto. O Açúcar na Madeira: produção e comércio nos séculos XV a XVII. In: Producción y comercio del azúcar de caña en época pré-industrial. Actas del Tercer Seminario Internacional. Granada: Diputación Provincial de Granada, 1993. p. 4.

${ }^{181}$ Ibid., p. 5.

${ }^{182}$ VIEIRA, Alberto. Portugal y las islas del Atlántico. Madrid: Editorial MAPFRE, 1992. p. 156.
} 
grande modificação na estrutura socioeconômica dos países que as implantaram. Como enfatiza Viera:

A cana sacarina, ao contrário do que sucedeu com as demais culturas transplantadas pelo europeu para o espaço atlântico (vinha, cereais, pastel), não se resumiu apenas à intervenção no processo econômico. Ela foi marcada por evidentes especificidades capazes de moldarem a sociedade, que dela se serviu para firmar a sua dimensão econômica. A importância a que o sector comercial lhe atribuía conduziu a que fosse uma cultura dominadora de todo (ou quase todo) o espaço agrícola disponível e apto para o seu cultivo, capaz também de estabelecer os contornos de uma nova realidade social ${ }^{183}$.

Assim pode-se observar o quanto esta matéria prima representou para o contexto Atlântico, bem como para as subsequentes regiões que vieram a adotá-la. Apesar da região do Atlântico mostrar-se muito propícia para o cultivo da cana-de-açúcar, isso não se processou em todas as ilhas com a mesma intensidade, e nas ilhas onde obteve maior sucesso, que seria o caso de Madeira e São Tomé, nem todas as regiões mostrou-se favorável ao plantio. Na Madeira, o plantio da cana conquistou as regiões meridionais e o Nordeste, que se apresentaram mais propícias ao plantio da mesma. Enquanto na primeira área o clima favoreceu a expansão até os quatrocentos metros de altitude, na segunda, dominada por Porto da Cruz e Faial, não ultrapassava os 200 metros ${ }^{184}$. Em São Tomé, o plantio da cana sacarina mostrava-se mais apropriado na região norte e nordeste, onde possui uma paisagem bem diferente, observada em outras ilhas, não só pelo fato dessas regiões as formas mais jovens da construção estrutural da ilha, mas também pelas condições climáticas serem muito mais adequadas. Mostrou-se ser uma área na qual as chuvas raramente ultrapassavam o necessário utilizado nos cultivos, que de certa forma se encontra subtraída à ação umedecida do vento ${ }^{185}$. Nesta ilha, o solo resulta essencialmente na ação conjunta de várias fatores, como a natureza da rocha de base, das condições de climas, do vigor e movimento do relevo, da maior ou menor microrganismo neles existentes da vegetação que suportam e ainda pelo fator tempo ${ }^{186}$.

\footnotetext{
${ }^{183}$ VIEIRA, Alberto. O Açúcar na Madeira: produção e comércio nos séculos XV a XVII. In: Producción y comercio del azúcar de caña en época pré-industrial. Actas del Tercer Seminario Internacional. Granada: Diputación Provincial de Granada, 1993. p. 2.

${ }^{184}$ VIEIRA, Alberto. O Açúcar na Madeira: produção e comércio nos séculos XV a XVII. In: Producción y comercio del azúcar de caña en época pré-industrial. Actas del Tercer Seminario Internacional. Granada: Diputación Provincial de Granada, 1993. p. 6.

${ }^{185}$ TENREIRO, Francisco. A Ilha de São Tomé. Lisboa: Junta de Investigações do Ultramar, 1961. p. 31.

${ }^{186}$ TENREIRO, Francisco. A Ilha de São Tomé. Lisboa: Junta de Investigações do Ultramar, 1961. p. 45.
} 
Já em Cabo Verde, a produção só se deu na ilha de Santiago, isto em uma proporção muito reduzida, se compararmos com as ilhas de São Tomé e a da Madeira. Para Nunes (2002), segundo Valentim Fernandes, no primeiro decênio do século XVI, a ilha de Santiago oferece muito dos frutos de Portugal que nela plantam: figos, uvas, melões, etc., mostra-nos ainda, que a carta régia de 25 de janeiro de 1540, tem-se informação de que na ilha laboram dois engenhos trapiches de fazer açucares com todo o cobre e mais causas necessárias aos ditos engenhos ${ }^{187}$. Para Nunes, baseado no trabalho Pereira e Santos, em 1508 e 1509, já se vendem, em Lisboa, açúcar de Santiago, enquanto, só em finais do século XVII começa a produção de açúcar em Santo Antão, devido às dificuldades de acesso à ilha ${ }^{188}$.

Os portugueses chegam a Cabo Verde em 1460 e, tal como nas outras regiões por eles povoadas e colonizadas, a cana-de-açúcar foi uma das primeiras plantas introduzidas. No entanto, nos séculos XV e XVI, em Cabo Verde, a cana-de-açúcar não atinge a dimensão produtiva da Madeira, Canárias e depois S. Tomé, devido às condições naturais desta região, que se revelam pouco favoráveis à produção açucareira. $\mathrm{Na}$ documentação histórica, a primeira referência que encontramos da produção de cana-de-açúcar, em Cabo Verde, data de $1490^{189}$.

Existe uma escassez de água muito grande na grande parte ou em grande maioria das ilhas que fazem parte do arquipélago de Cabo Verde e isso repercute de forma muito profunda para aridez do clima. A chuva nesse arquipélago só cai durante três meses, sendo os restantes dos meses muito seco e ventoso. Esses foram os principais obstáculos que levaram os portugueses a não introduzirem a cana sacarina nesta região, como fora na ilha da Madeira e, posteriormente, nas outras Ilhas que compõem o Atlântico, porque por ali havia mão de obra servil em abundância, proveniente da costa africana fronteira para os trabalhos da plantação e mesmo da transformação ${ }^{190}$. Das poucas plantações feitas neste arquipélago, foram restritamente na ilha de Santiago, onde pode-se encontrar rios correntes para manutenção das plantas bem como mover os poucos engenhos por ali existentes.

\footnotetext{
${ }^{187}$ NUNES, Naidea Nunes. O açúcar de cana na ilha da Madeira: do Mediterrâneo ao Atlântico Terminologia e tecnologia históricas e actuais da cultura açucareira. 2002. 778 f. Tese (Doutorado em Linguística Românica) - Faculdade de Artes e Humanidades, Universidade da Madeira, Funchal, 2002. p. 11.

${ }^{188}$ Ibid., p. 12.

${ }^{189}$ Ibid., p. 13.

${ }^{190}$ Magalhães, Joaquim Romero. O açúcar nas ilhas portuguesas do Atlântico séculos XV e XVI. Varia
} Historia, Belo Horizonte, v. 25, n. 41, p. 151-175, 2009. p. 168. 
Em Açores, a situação seria muito semelhante com o que ocorrera na ilha da Madeira, mas o sucesso da cana bem menor, pois inicialmente a produção do açúcar na região do mediterrâneo encontrava-se em alta, o que teria também monopolizado o mercado consumidor, onde as principais frotas de açúcar viriam desta região, por outro lado, os portugueses estavam engajados em um produto que estaria muito escasso internamente, que seria o cereal, este em Açores, encontrou uma adaptação em boa parte das ilhas. Magalhães ${ }^{191}$, mostra-nos que o primeiro capitão de São Miguel, Gonçalo Velho, como o segundo, João Soares de Albergaria, pouco de lá teriam recebido, relativo a produção açucareira, por isso João Soares vendeu a sua capitania a Rui Gonçalves da Câmara, filho do capitão do Funchal, por 2 mil cruzados em dinheiro e 4 mil arrobas de açúcar e o novo donatário era filho de João Gonçalves Zarco, o capitão do Funchal. Mas a venda das capitanias não resultou em grande prosperidade, pois em 1474, a ilha de São Miguel era muito mal aproveitada e pouco povoada. A povoação na grande maioria das ilhas descobertas pelos portugueses, neste principiar do século, se processava em torno da produção que ali implantasse, assim se em algumas dessas regiões não conheceram sucesso ou não mostraram capazes de produzir bens que mais demandasse no mercado, fazia retrair os colonos e consequentemente os trabalhadores, que em grande medida constituía a massa populacional da época. A colonização dos Açores foi empreendida nos mesmos moldes da Madeira, com a instituição de capitanias e uma vez mais, a preferência dos colonos se virou logo no início para a cultura do trigo, que as ilhas açorianas se mostravam grandes produtoras. Devido o êxito da cana do Madeira, os portugueses viram por bem transplantá-las para as ilhas açorianas, como forma de manterem as mesmas qualidades do açúcar que se vinha produzindo. Na ilha de Santa Maria, ao mando do Infante dom Henrique, começaram as primeiras plantações. Um catalão, mestre António, teria sido enviado para lá com esse propósito. Mas ainda não havia moendas, o que exigiu que as canas fossem levadas para São Miguel. Por falta de interesse, de capitais e escassez de águas, resultou em abando ou desistência de grande parte dos agricultores produtores de cana. Nos finais do século XV a ilha rendia bem em trigo e em urzela, mas não há vestígios de açúcar. Nas outras ilhas também se experimentou, mas o êxito terá sido sempre limitado, salvo em São

\footnotetext{
${ }^{191}$ Magalhães, Joaquim Romero. O açúcar nas ilhas portuguesas do Atlântico séculos XV e XVI. Varia Historia, Belo Horizonte, v. 25, n. 41, p. 151-175, 2009. p. 163.
} 
Miguel. A conjugação de abundantes chuvas com temperaturas relativamente quentes não era fácil de ocorrer num clima atlântico temperado. Mas algum açúcar se ia fazendo.

Para afirmação dos canaviais foram necessárias algumas condições essenciais, normalmente oferecidas pelo solo, e do próprio ecossistema, tais como: a água para regar as canas, bem como dar suporte ao funcionamento dos engenhos; a madeira para construção das casas e a lenha para usarem nos funcionamentos das caldeiras. Graças a tais fatores a cana sacarina encontrou o sucesso e se expandiu nas ilhas e outras regiões onde oferecia características semelhantes.

\begin{tabular}{|c|c|}
\hline \multicolumn{2}{|r|}{ Expansão da Cana-De-Açúcar no Mundo } \\
\hline Ano & Região \\
\hline 1000 & O açúcar é uma das mercadorias mais importantes do comércio do Mediterrâneo \\
\hline 1285 & Marco Pólo refere o fabrico de açúcar na China, Índia e África Oriental \\
\hline 1305 & Primeira referência à cana-de-açúcar em Valencia \\
\hline 1425 & $\begin{array}{l}\text { Expansão da cana-de-açúcar ao Atlântico, a partir da Madeira: } 1474 \text { - Açores; } \\
1483 \text { - Canárias; } 1484 \text { - S. Tomé; } 1498 \text { - Cabo Verde. }\end{array}$ \\
\hline 1483 & $\begin{array}{c}\text { O governador de Gran Canária D. Pedro de Vera manda buscar à Madeira canas } \\
\text { e mestres para a introdução cultura em Gran Canária e La Palma }\end{array}$ \\
\hline 1484 & Primeira experiência da cultura da cana-de-açúcar em S. Tomé \\
\hline 1485 & $\begin{array}{l}\text { A coroa recomenda a Afonso da Paiva a cultura de canaviais em S. Tomé com } \\
\text { gentes da Madeira }\end{array}$ \\
\hline 1509 & Primeiras plantações de cana-de-açúcar no Brasil \\
\hline 1640 & Início do cultivo da cana-de-açúcar em Barbados \\
\hline 1651 & Primeira plantação de cana-de-açúcar em Suriname por Lord Willoughby \\
\hline 1751 & Introdução da cana-de-açúcar em Louisiana \\
\hline 1788 & $\begin{array}{l}\text { Introdução da cana-de-açúcar em Cape Colony na Austrália, sendo Thomas Scott } \\
\text { quem iniciou a indústria }\end{array}$ \\
\hline 1890 & $\begin{array}{c}\text { Criação em Java e Barbados de Estações agronómicas para selecção das } \\
\text { diversas variedades de cana-de-açúcar }\end{array}$ \\
\hline
\end{tabular}

Tabela 1: Expansão da Cana-De-Açúcar, a partir dos Anos 1000 D.C. ${ }^{192}$.

\footnotetext{
192 Nesta tabela, buscou-se, cronologicamente somente as regiões nas quais houve a plantação da cana sacarina ou produção do açúcar a partir do ano 1000. Vê-se também que na tabela, os países do Atlântico datam em 1425, mas percebe-se que em frente de cada país, no lado direito da tabela, estariam às datas da introdução da cana sacarina dos diferentes países. Adaptado de Alberto Vieira. Disponível em: <http://www.avieira.net>. Acesso em: 10 ago. 2016.
} 


\section{2 - Nível produtivo}

A produção do açúcar no Atlântico começa na ilha da Madeira, que experimentou um grande sucesso devido às condições favoráveis encontradas no local. Em todas as ilhas não se processou de forma igual, pois a cana sacarina exigia um bom pedaço de terras férteis e água em abundância para dinamizar este processo. Nos Açores, Canárias, Cabo Verde e as subsequentes ilhas descobertas no Golfo da Guiné não mostraram tais características. Certamente para as ilhas do Golfo da Guiné, somente São Tomé e Príncipe o sucesso foi pleno, onde as características exigidas para a produção açucareira encaixariam perfeitamente. Como mostra Magalhães:

E será essa uma ilha que satisfará plenamente os requisitos para a aclimatação da cana-de-açúcar - água em abundância, temperaturas elevadas, solo fértil - que primeiro havia que limpar da sua densa cobertura de árvores de grande porte ${ }^{193}$.

Apesar das Ilhas do Golfo da Guiné serem da mesma origem vulcânica, o que aparentemente suporíamos que deveria possuir as mesmas características para a instalação e produção da cana sacarina, não obstante isso não ocorreu. De todas as ilhas, São Tomé mostrou ser mais profundamente humanizada, devido à abundancia de terra assente, plana e bem irrigada, apesar de alguns relevos vigorosos no seu interior. $\mathrm{Na}$ ilha de Fernando Pó, a antiga Ilha Formosa, possui uma planície litoral muito estreita declinante, favorecendo desta forma, obstáculos a penetração humana, enquanto que no Ano Bom é menos favorecido o clima, o mesmo ocorre com a ilha do Príncipe ${ }^{194}$.

O rendimento do açúcar nas ilhas açorianas foi muito reduzido, se compararmos com a ilha da Madeira e outras ilhas posteriormente produtoras no atlântico. De1502 a 1505, a fazenda régia arrecadou 5.000 arrobas anuais neste arquipélago, totalizando nesses três anos 15.000 arrobas em produção. Em 1509, houve um aumento para 20.000 arrobas, enquanto na Madeira atingiu, nesse mesmo período valor muito superior. Isso mostra o quanto a produção nesta região era próspera, que talvez viesse para ficar. A

${ }^{193}$ MAGALHÃES, Joaquim Romero. O açúcar nas ilhas portuguesas do Atlântico séculos XV e XVI. Varia Historia, Belo Horizonte, v. 25, n. 41, p. 151-175, 2009. p. 169.

${ }^{194}$ TENREIRO, Francisco. A Ilha de São Tomé. Lisboa: Junta de Investigações do Ultramar, 1961. p. 10. 
produção seria mais para suprir as necessidades locais, não atingiria a qualidade e as quantidades de uma colheita para exportação como a que se instalara na Madeira ${ }^{195}$.

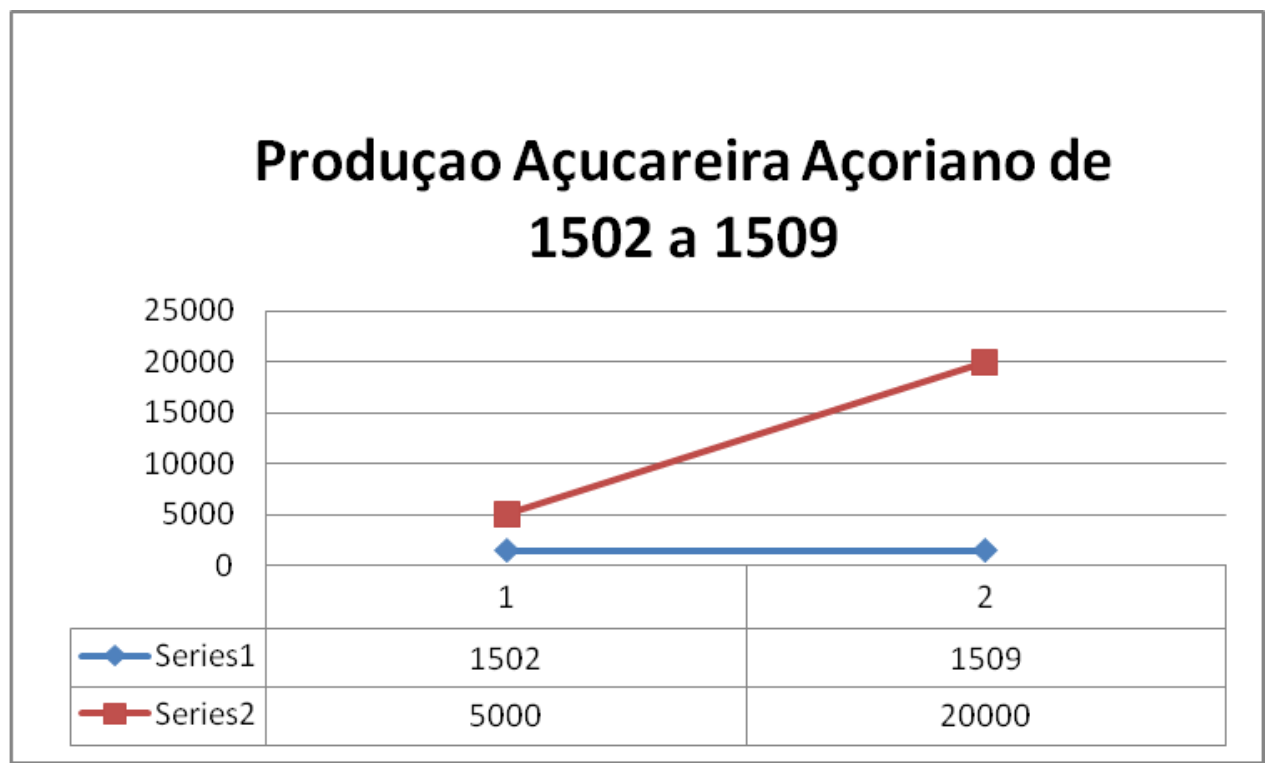

Gráfico 2: Produção Açucareira em Açores, de 1502 a 1509.

O gráfico 2 mostra o quão improdutivo foi a ilha dos Açores em comparação com outras ilhas da região. De 1502 a 1509, a ilha produziu aproximadamente 20.000 arrobas de açúcar, o que se for fazer a média anual, daria em torno de 3.000 arrobas anuais. Embora o sistema produtivo se processasse de forma diferente nas ilhas do atlântico, sabe-se que para a média anual produzida, as ilhas como a da Madeira e a de São Tomé mostram-se muito mais rentável.

Embora nesta época não ficasse muito claro, mas ocorria uma espécie de produtos especializados entre as ilhas de Madeira e de Açores, ou seja, para Açores era reservada em grande medida a produção de trigo, na qual apresentava melhor capacidade produtiva enquanto para Madeira reservava-se a produção de açucares, onde oferecia melhores condições e mobilidade para fazê-lo. A estas ilhas destinava-se a produção de trigo que interessava ao Portugal deficitário em cereais - o que permitia ainda à ilha da Madeira dedicar-se ao açúcar, recebendo o pão dos Açores. A especialização ocorreu. E a cultura da cana doce, por fracos rendimentos iniciais, terá sido abandonada, ou menos prezada. Por 1540, para fazer frente a dificuldades grandes,

\footnotetext{
195 MAGALHÃES, Joaquim Romero. O açúcar nas ilhas portuguesas do Atlântico séculos XV e XVI.
} Varia Historia, Belo Horizonte, v. 25, n. 41, p. 151-175, 2009. p. 163. 
tentou-se retomar uma produção que em outros lados se sabia que tinha mercado no exterior. E que permitia diversificar as culturas, pelo menos na ilha de São Miguel. Com resultados que não atingiram o que se pretendia. Por razões naturais, pela pouca aptidão do clima em especial. Sem que se esqueçam as razões comerciais. É que nos finais do século XVI já nem a qualidade do açúcar madeirense podia fazer frente a produção brasileira. Porque esta era agora a região exportadora de açúcar. Com dois concorrentes tais - apesar de ocorrerem em dois tempos diferentes -, o açúcar açoriano nunca se destacou no mercado internacional. E acabou por ser quase esquecido: no século XVII não há vestígios dessa cultura nas posturas municipais de Ponta Delgada, exceto a região da Vila Franca do Campo que obteve alguns engenhos. Nos meados século XVII se produziu também muito bons açúcares nesta vila, onde até hoje são produzidos ${ }^{196}$.

Em 1546, já se escreve que nesta ilha as mais pessoas dela vivem de vinhos. Isto apesar de ainda se considerar que o acréscimo de tributos sobre o açúcar é em muito prejuízo de todos os moradores da ilha. Fórmula que teria servido por muitos anos. Mas agora o açúcar da ilha da Madeira tinha o seu tempo passado. Era o vinho que doravante avultava no comércio internacional. Nos anos oitenta a média anual de produção terá andado pelas 36.000 arrobas $^{197}$.

Em 1455, na ilha da Madeira já se produzia 1.600 arrobas de açúcar, mas durante muito tempo, a ilha encontrou algum obstáculo na produção. Por aproximadamente três quarto de século o crescimento produtivo encontrou certos gargalos de escoamento, pois ainda em alguma região o açúcar continuava sendo um produto não muito necessário, o que tornou inviável a sua produção. Por volta de 1470 , a produção estava em torno de 20.000 arrobas e deste período em diante entraria em rápido crescimento, no ano seguinte estaria em 30.000 arrobas ${ }^{198}$. Para o ano de 1494, estima-se que produção gerava em torno de 105.000 arrobas, sendo que os canaviais de Funchal produziram 80.451 arrobas, representando 3/4 da produção insular, e as restantes partes produzidas pela Machico representariam 1/4 da produção. No último decênio deste século, o açúcar sofre um grande obstáculo nesta ilha, trazendo uma retração na

\footnotetext{
196 MAGALHÃES, Joaquim Romero. O açúcar nas ilhas portuguesas do Atlântico séculos XV e XVI. Varia Historia, Belo Horizonte, v. 25, n. 41, p. 151-175, 2009. p. 160.

197 Ibid., p. 161.

198 GODINHO, Vitorino Magalhães. Os descobrimentos e a economia mundial. Lisboa: Editorial Presença, 1963. v. 4. p. 75.
} 
produção e, consequentemente, para sua exportação. A queda de preço fez acumular excessivamente a produção o que veio a repercutir relativamente no seu escoamento, multiplicando assim a dívida. Em um quarto do século o preço do açúcar na ilha da Madeira baixa entre 650 reais e 800 reais para 310 e 340 em 1492 - 1494. Neste período, houve uma deflação de mais de $50 \%$ na queda do preço, o que para uma produção não seria nada saudável. De forma mais precisa, se se esperava ter uma venda na faixa de 100.000 arrobas para o ano em análise, com a queda do preço vigente, o valor da venda depreciaria para 48.000 arrobas aproximadamente. Se fizermos o mesmo cálculo para o ano de 1494, a situação é bem mais deplorável, ou seja, se em 1492, a deflação foi de 52\%, este valor subiria para 58\%, em 1494, o que reduziria o valor total das vendas em um percentual bem maior, nesse caso, de 100.000 arrobas esperados na venda total, seria somente 42.000 arrobas em receita. Com isso pode-se ter uma ideia, que a partir das deflações constatadas, o que seriam as novas despesas com fator produtivo, que para o período, seria fatal para renovação de tais produções. Para o ano de 1492, para amenizar a situação vigente, foi implantado um regimento datado em 07 de Outubro, fixando a taxa do preço mínimo em 350 reais para açúcar de uma cozedura e em 600 para o de duas cozeduras. A partir de 01 de outubro de 1499, não se poderão fazer na ilha mais de 120.000 arrobas de açúcar anualmente. A produção açucareira volta a conhecer prosperidade, sendo que no ano 1504 a produção teria atingido as 182.000 arrobas, subindo para $230.000 \mathrm{em} \mathrm{1506.} \mathrm{Mas} \mathrm{depois} \mathrm{começa} \mathrm{a} \mathrm{baixar,} \mathrm{atingindo}$ apenas 115.000 arrobas em 1518. Pior será daí em diante. Das 106.000 em 1521 só chegará a 46.000 arrobas em $1537^{199}$.

199 MAGALHÃES, Joaquim Romero. O açúcar nas ilhas portuguesas do Atlântico séculos XV e XVI. Varia Historia, Belo Horizonte, v. 25, n. 41, p. 151-175, 2009. p. 160. 


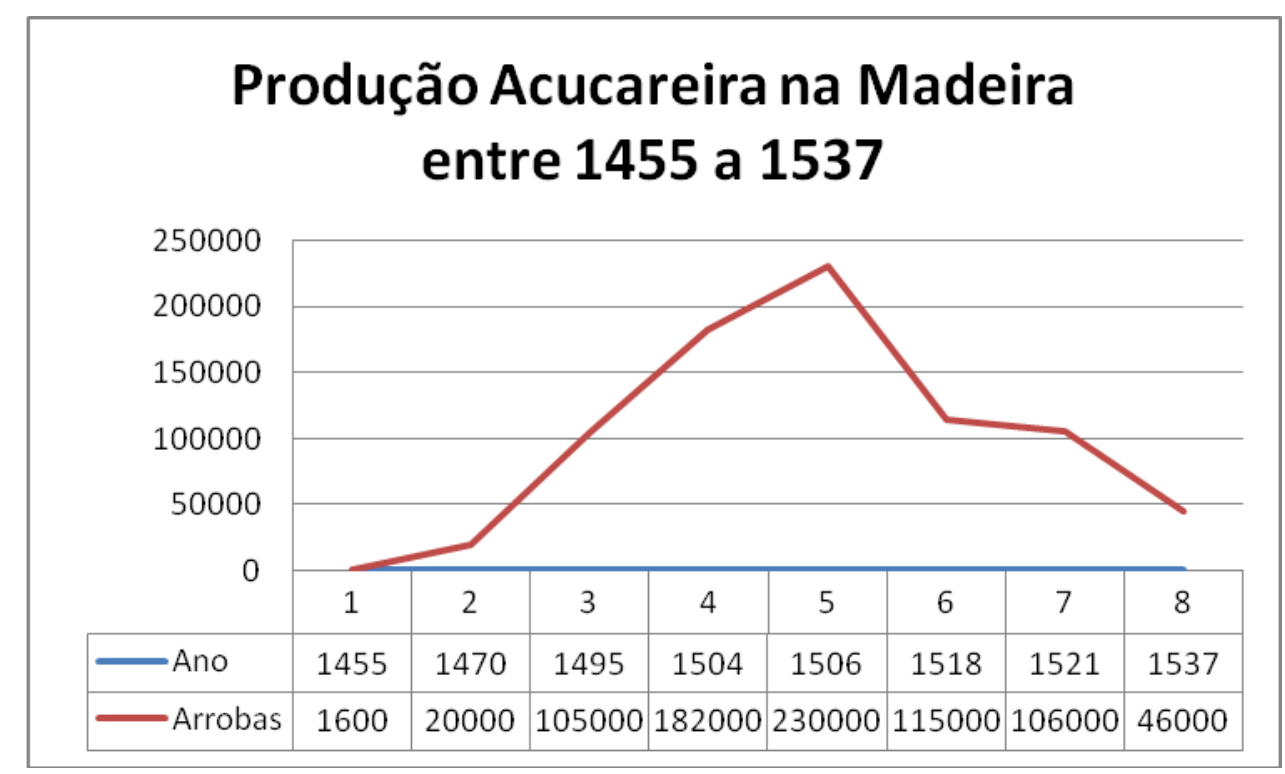

Gráfico 3: Produção Açucareira na Ilha da Madeira de 1455 a 1537.

No gráfico acima, fica mais evidente compreender a situação que estagnou a produção no último quartel do século XV. No entanto, havia a questão do preço envolvendo o fator produtivo. Mas este fator preço ao médio longo prazo viera a favorecer as vendas do produto, uma vez que o produto começou a ser, cada vez mais e mais conhecido, e com maior facilidade de compra. Se antes este produto era consumido por uma classe de mais alta renda, com o preço baixo, boa parte da população era incentivada a consumir o produto. Para tanto, nos anos seguintes, após a instauração de algumas políticas, embora o preço permanecesse baixo, as produções subiram e, consequentemente, o lucro das empresas.

Apesar de haver toda uma política de preservação do preço do açúcar que mantivesse a produção elevadas internamente, não obstante, muito pouco se poderia fazer quando aumentou a concorrência da mesma produção, resultando deste modo em um maior endividamento. Com a dívida alta, por conta da retração na venda do produto em estoque, poderia provocar em médio prazo, um ciclo vicioso, na medida em que essa retração da venda ocasionaria uma redução de novos investimentos. Com a redução de novos investimentos, novas matérias primas e outros custos com produção estariam comprometidos e, consequentemente, uma redução na produção. Apesar da queda de produção em algumas regiões do Atlântico, muitas das regiões encontravam com a produção em plena ascensão, que seria o caso de São Tomé, as Antilhas, Canárias e, posteriormente, o Brasil, países que possuíam condições favoráveis ao plantio de cana sacarina e produção açucareira. Essa nova concorrência veio de algum modo a 
comprometer a produção da Madeira, que, inicialmente, encontrava-se em nível crescente da produção. Essas dificuldades na produção madeirense devem-se, sobretudo, ao fato de ter surgido em uma época onde a principal produtora do mediterrâneo encontrava-se em momentos de instabilidade, podendo assim, vender a sua produção para todos os mercados aonde antes estaria concentrada na antiga produtora. Por outro lado, quando inicia a produção das outras ilhas do atlântico, essas novas regiões, além de entrarem na concorrência com a ilha da Madeira, passaram também a abastecer seu mercado interno, o que veio a dificultar a produção madeirense. Se a venda dos açucares produzidos no final do século XV e início do século seguinte, dependia em grande medida, do mercado externo, e se a qualidade do produto era levada em conta, logo os açucares de Madeira não eram de tão boa qualidade, assim como muitos alegam, e provavelmente os açucares de novas áreas produtoras, superariam a qualidade da ilha da Madeira. Nesta, provavelmente, o açúcar produzido nas Canárias, em São Tomé, nas Antilhas e anos depois, no Brasil seriam de alta qualidade, a produção dessas novas regiões impactou sobremedida a produção da ilha da Madeira, o país que até então detinha o monopólio no Atlântico. Assim, fez baixar a demanda nesta região detentora do monopólio, reduzindo o preço global do produto, disseminando deste modo, com maior velocidade, por toda região por onde ainda não se consumia este produto.

Parece que a ilha de São Tomé começou a produzir as primeiras arrobas de açúcar em 1495, período que segundo Lains e Silva ${ }^{200}$, já houvesse chegado o primeiro carregamento deste produto na Europa, sendo que Antuérpia no período em estudo, pertencer a uns dos maiores mercados consumidores de açúcar no período em questão. Para Silva, em 1495, o processo do desenvolvimento produtivo tenha sido lento, não obstante a produção continuou sendo processada. Sabe-se que em 1517 existiam poucos engenhos produtores de açúcar, por volta de dois ou três no máximo, situação que veio a perdurar até por volta de 1529 . A partir de 1529 , a produção gerava em torno de 50.000 arrobas o que gerava uma renda para a coroa de 5.000 arrobas, mas essa quantidade seria muito irrisória frente do que eram produzidas na ilha da Madeira ${ }^{201}$. Já para Alberto Vieira, por volta de 1517 , a produção já se encontrava na cifra de 100.000 arrobas e, segundo o autor, o desenvolvimento açucareiro em São Tomé se fez em

\footnotetext{
${ }^{200}$ LAINS E SILVA, Hélder. São Tomé e Príncipe e a cultura do café. Lisboa: Junta de Investigações do Ultramar, 1958. p. 83.

${ }^{201}$ Ibid., p. 84.
} 
pouco tempo e passaria a ilha da Madeira que produzia na mesma época 93.000 arrobas de açúcar, que nunca passaria a faixa das 144.000, pelo menos até 1510. Devido os avanços do plantio nas terras, uma situação incentivada pela própria coroa portuguesa, em 1520 a produção em São Tomé atingiria aproximadamente 120.000 arrobas e na década de quarenta subiria para 150.000 arrobas anuais ${ }^{202}$.

Haveria possibilidade de produzir mais açúcar em São Tomé visto as condições oferecidas pela terra serem semelhantes à da Madeira - com alguns atributos adicionais, mas a coroa portuguesa vivia com problemas e tarefas vastas o que impossibilitava dar maior atenção ao comércio do açúcar nessa ilha. O rei de Portugal era simultaneamente o principal senhor agrário e o mercador, assim reservava a prioridade ao comércio $^{203}$. Mas visto a demanda do produto no mercado internacional, o rei viu a necessidade de se concentrar maior atenção na produção deste produto, ordenando ao seu Feitor João Lobato, ainda em 1429 que instalasse mais doze engenhos, adicionado aos já existentes, assim passaria a ser explorados por contratadores. A partir deste momento, a indústria açucareira começou com uma maior ênfase em São Tomé, e o seu progresso foi rápido, deste período em diante, em simultâneo com o aumento do comércio em Flandres.

Segundo o piloto da Vila de Conde, por volta de 1551, vivia São Tomé do açúcar, em contrapartida importava todos os gêneros de consumo corrente, como farinha, vinho, azeite, queijo, couro, espadas, taça de vidro, contas e até búzios e isso de alguma forma veio a fomentar uma maior dinâmica na economia desta ilha, pois se começou a consumir vários outros produtos que nesta região não seria possível produzir. Supõe-se que por ali existiam 60 engenhos movidos a água para produzir o açúcar, dados quantitativos, baseados a partir de dízimos, indicam em torno de aproximadamente 14.000 arrobas. Acredita-se que estes valores poderiam exceder a faixa calculada uma vez que muitos produtores não pagavam por inteiro, tais taxas, outros ainda fugiam do pagamento de tributos, deixando de pagá-los, como fora muito frequente nestas ilhas, e se levassem com todo o rigor o pagamento de tais taxas, provavelmente o valor em causa poderia duplicar ou até quadruplicar. Muitas taxas eram cobradas muito antes de haver colheita, por tal fato, fica difícil mensurar, no final da colheita, quando de produtividade foi feita em determinado ciclo produtivo. Este fato vem reforçar a ideia de que as produções feitas nas diferentes regiões do Atlântico

\footnotetext{
${ }^{202}$ VIEIRA, Alberto. Portugal y las islas del Atlántico. Madrid: Editorial MAPFRE, 1992. p. 168.

${ }^{203}$ LAINS E SILVA, Hélder. São Tomé e Príncipe e a cultura do café. Lisboa: Junta de Investigações do Ultramar, 1958. p. 84.
} 
poderiam ser bem diferentes do que muitas das vezes são auferidas pelos possíveis produtores, pois na possibilidade de terem um lucro maior, omitiria o montante total da safra e, consequentemente, o que levaria, em uma data futura, a pagarem uma taxa menos para a coroa e para a igreja. No processo colonial, havia dois interesses entrelaçados, quando se fala da produção dos artigos implantados nas colônias, no caso de cana-de-açúcar, mesmo antes de introduzi-la no solo, as taxas já eram cobradas, uma forma de garantir os lucros da Fazenda Real, independente da condição do mercado. Além das taxas sobre a produção, a Coroa portuguesa também cobrava uma taxa de $10 \%$ sobre a exportação do açúcar ${ }^{204}$. O sucesso do açúcar nesta ilha era tanto, que em curto espaço de tempo, ou seja, em duas décadas, os números de engenho quintuplicaram e a produção destes produtos se multiplicara em trinta vezes do que já se produzia $^{205}$.

Os visitantes destas ilhas afirmavam possuir, em 1578, mais de setenta engenhos que produziam açúcar. Estavam, contudo, neste período em franco declínio, por causa das pragas existentes em algumas regiões onde havia cana do açúcar, repercutindo assim sobre a sua produção ${ }^{206}$. Antes da praga, a ilha teria chegado a produzir anualmente quarenta naus grossas de açúcar, o que gerava em torno de 800.000 arrobas, considerando que cada um desses barcos carregasse 20.000 arrobas, mas isto não perdurou por todo o século, pois os ataques dos barcos estrangeiros ${ }^{207}$ e até mesmo dos forros revoltados veio reduzir a produção, diminuindo para quatro a cinco naus grossas, o equivalente ao aproximadamente 120.000 arrobas.

Anos seguintes, após os ataques, a produção açucareira voltou a conhecer nova prosperidade, como relata-nos Lains e Silva:

\footnotetext{
${ }^{204}$ Arquivo Nacional da Torre de Tombo (ANTT). As taxas cobradas no processo de colonização, na ilha de São Tomé, eram realizadas antes da colheita, ou seja, ao se introduzir a cana-de-açúcar nas terras, as taxas já eram recolhidas, uma forma de garantir os lucros da Fazendo Real, independente da condição do mercado. Além das taxas sobre a produção, a Coroa portuguesa também cobrava uma taxa de $10 \%$ sobre a exportação do açúcar. CC, II - 121 -104 (4 de Novembro de 1524), II- 128 - 69 (6 de Outubro de 1525) e II - 129 - 219 (13 de Novembro de 1525).

${ }^{205}$ LAINS E SILVA, Hélder. São Tomé e Príncipe e a cultura do café. Lisboa: Junta de Investigações do Ultramar, 1958. p. 84.

${ }^{206}$ LOPES, Duarte; PIGAFETTA, Filippo. Relação do reino de Congo e das terras circunvizinhas. Tradução de Rosa Capeans. Lisboa: Agência Geral do Ultramar, 1951.

${ }^{207}$ AHU-São Tomé. 1622, Maio, 31, Cascais, CARTA do ouvidor de Cascais, Luís de Aguiar Ribeiro, ao rei, Filipe III, sobre a chegada de um batel, vindo de São Tomé, com 18 homens que afirmavam que os holandeses os haviam atacado e roubado os navios, o açúcar, alguns escravos e morto o mestre e o condestável; informando que levara os escravos e um moleque dos sobreviventes à alfândega de Lisboa; referindo ainda ao ataque dos soldados do capitão João Barbosa, do terço de D. Fradique, a uma nau de França que trazia vários moios de trigo. Obs.: m. est.; anexo: auto, cx. 1, doc. 68.
} 
De passagem da carta de Frutuoso Ribeiro ao padre Francisco Mariz, datada de 14 de Março de 1580, em que relata a sua viagem de Lisboa, donde partiu em outubro de 1579 para Luanda, donde chegou em Fevereiro de 1580, se infere ser então a produção de açúcar em ao Tomé de 200.000 arrobas. Referindo a São Tomé, diz: "Por estes arvoredos estão semeados grandes canaviais de açucares, os quais parecem para quem vê os campos de Alentejo semeado o trigo. Nesta ilha se carrega cada ano dez ou doze navios de açúcar para esse reino e o El-Rei Nosso Senhor rendem os açucares cada ano 20.000 arrobas". Haveria então cento e vinte engenhos ${ }^{208}$.

Entre 1589 e 1592, na gerência de Gaspar Cadena, o então recebedor de São João, a coroa tinha um rendimento de apenas 64.309 arrobas por ano, e vinte anos mais tarde não ultrapassariam 60.000 arrobas. A decadência do açúcar em são Tomé seria em razão de vários acontecimentos, externos e internos que proporcionaram tais fatos. Se por um lado temos as instabilidades sociais reinando no período, por outro lado, em consequência das tais instabilidades, começou a haver grandes invasões feitas pelos consórcios franceses, ingleses e holandeses. Devido à rentabilidade que o açúcar começou a ter nos mercados internacionais, outras potências europeias começaram a se interessar muito pelo produto, pelo que, a partir do final século XVI, ou pouco antes, via-se muitos barcos holandeses, ingleses e franceses nas principais regiões do Atlântico onde produziam muito açúcar ${ }^{209}$. Os interesses das grandes potências europeias pelo comércio do açúcar geravam, de alguma forma, grandes atritos entre eles. Os holandeses contra ingleses, os ingleses contra os franceses, e todos eles cobiçavam a produção feita pelos portugueses, o que tornava muito fragilizada as regiões nas quais as empresas portuguesas eram instaladas ${ }^{210}$. A rentabilidade do açúcar proporcionou a seus produtores certa resistência em termos das possíveis instabilidades ali existentes. O que

\footnotetext{
${ }^{208}$ LAINS E SILVA, Hélder. São Tomé e Príncipe e a cultura do café. Lisboa: Junta de Investigações do Ultramar, 1958. p. 85.

${ }^{209}$ AHU-São Tomé, ant. 1635, Janeiro, 16, Lisboa, INFORMAÇÃO, do secretário das Mercês e Expediente, Francisco de Lucena, sobre o comércio de açúcar, e tráfico de escravos, dos ingleses e dos holandeses, entre São Tomé e Londres, mencionando a colaboração de um criado italiano do governador Lourenço Pires de Távora, de um marinheiro chamado Prata e do contramestre Parola e a abertura de duas lojas inglesas na fortaleza portuguesa. Obs.: inclui auto de inquirição a Manuel Fernandes Prata e a Jorge Godinho, mencionando a participação do piloto português, Manuel Mendes, e do mercador do Funchal, Diogo Fernandes Branco, no comércio com os estrangeiros; anexo: auto de inquirição. Cx. 2, doc. 8 e 6.

${ }^{210}$ AHU-São Tomé, 1636, Janeiro, 8, Lisboa, CONSULTA do Conselho da Fazenda ao rei, D. Filipe III, sobre o requerimento do governador de São Tomé, António de Sousa de Carvalho, solicitando licença para embarcar para aquela ilha numa nau inglesa, em virtude de não haver portuguesas disponíveis, assegurando que a dita nau levaria piloto e mestre português e daria fiança aos direitos reais, querendo carregar açúcar e mercadorias para trazer a Lisboa, [sendo apta a resistir aos holandeses que navegavam entre Luango e cabo Lopo Gonçalves, capturando os navios mercadores]. Obs.: resolução da regente, duquesa de Mântua, D. Margarida de Sabóia. Ver: AHU_CU_CONSULTAS DE PARTES, Cód. 41, fl. 58-58v; anexo: requerimento, informação, cartas régias., cx. 2, doc. 24 e 10.
} 
se pode aperceber é que nesta região, apesar das instabilidades reinantes, as produções continuavam sendo feitas, tendo apenas algumas recaídas ou queda produtiva nos momentos de instabilidade. Vê-se na tabela 1 que entre 1536 e 1550, a Ilha de São Tomé, dentre várias regiões produtoras do açúcar, é o que mais exportou este produto para o maior mercado consumidor deste gênero. Temos que neste período, houve nesta ilha, várias instabilidades sociais, inclusive invasões estrangeiras já mencionadas.

\begin{tabular}{|l|c|c|c|}
\hline Proveniência & Carga do Açúcar $(\%)$ & Carga Mista $(\%)$ & Total \\
\hline Ilha da Madeira & $28(23,7)$ & $28(35,4)$ & 56 \\
\hline Ilha de Cabo Verde & $1(0,84)$ & $7(8,9)$ & 8 \\
\hline Ilha de São Tomé & $88(74,6)$ & $38(48,1)$ & 126 \\
\hline Canárias & $1(0,84)$ & $5(6,3)$ & 6 \\
\hline Brasil & - & $1(1,3)$ & 1 \\
\hline Total & $\mathbf{1 1 8}(\mathbf{1 0 0})$ & $\mathbf{7 9}(\mathbf{1 0 0})$ & $\mathbf{1 9 7}$ \\
\hline
\end{tabular}

Tabela 2: Navios Portugueses com Açúcar para Antuérpia (1536 - 1550).

Fonte: Adaptado de Godinho ${ }^{211}$.

Nas Canárias, a plantação de cana foi introduzida por altura de 1490 quase em simultâneo com a ilha de São Tomé que ocorrera provavelmente entre 1484 e 1485 . A descrição do arquipélago insere-se na coletânea V. Fernandes assinala abundância de açucares Grã-Canária. Os primeiros navios com melaço Canário ancoram em Antuérpia em 1508: chegada ficou celebrizada na pintura mural de Piet Verhaert, na Câmara Municipal. Como o número total de navios com carga para esse destino é de 197, os que levam a carga só de açúcar representam 66\% do trafego total, e o açúcar de São Tomé faz parte do carregamento de $73 \%$ dos navios que foram a Antuérpia, de total de açúcar transportado durante o período em estudo. Logo no início deste período, São Tomé estava em igualdade com a ilha da Madeira, e a partir de 1539, o primeiro país ultrapassaria consideravelmente o segundo. Verifica-se que a produção de Cabo-Verde não chega a alcançar a relevância internacional, provavelmente produzindo mais para o consumo interno. Quando o Brasil aparece em 1544, a mercadoria é reexpedida de Lisboa $^{212}$. Posto isso, a produção de São Tomé parece ter rendido muito mais para a coroa portuguesa, pelo menos até o meado do século XVI, se comparadas às ilhas do

\footnotetext{
${ }^{211}$ Baseado no rol da taxa avaria paga na feitoria portuguesa em Antuérpia, quadro de Virginia Rau, em exploração e o comércio do sal de Setubal, apêndice H; cálculo. Ver: GODINHO, Vitorino Magalhães. Os descobrimentos e a economia mundial. Lisboa: Editorial Presença, 1963. v. 4.

${ }^{212}$ GODINHO, Vitorino Magalhães Os descobrimentos e a economia mundial. Lisboa: Editorial Presença, 1963. v. 4. p. 99.
} 
Atlântico, produtora deste produto. Não se pode levar somente em consideração o fator da qualidade da terra, mas sim todos os fatores envolvendo o processo, deve-se levar muito em consideração o incentivo da própria coroa portuguesa, no período após descobrimento da ilha, deu grandes incentivos para que fossem a São Tomé, em sistemas de sesmarias, os colonos que quisesse ali se instalar e produzir este produto, um produto que representa grande demanda em nível do mercado internacional.

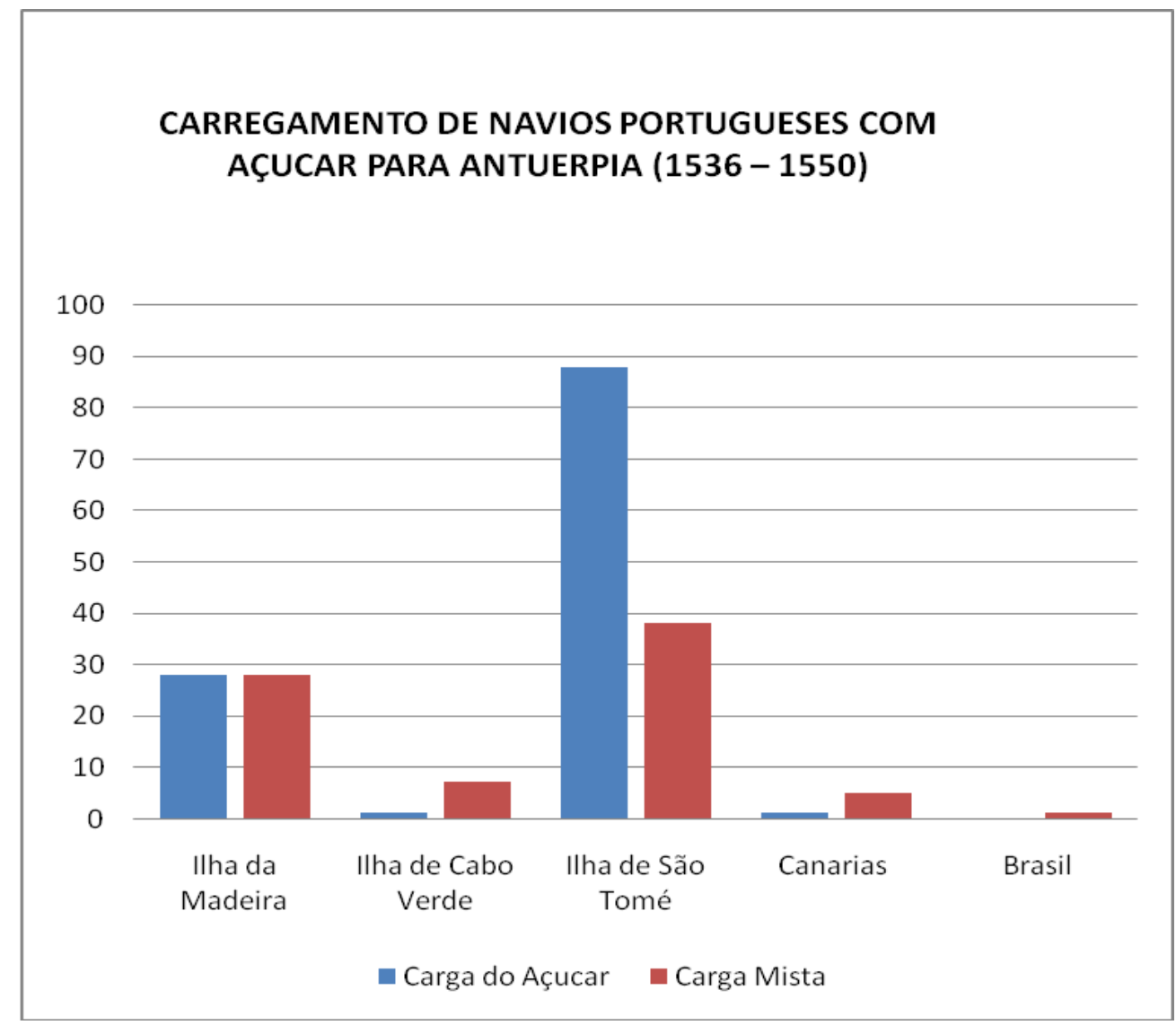

Gráfico 4: Carregamento do açúcar de Navios Português para Antuérpia (1536-1550).

O Brasil na tabela mostra-se com poucas levas do barco para Antuérpia, pois neste período, iniciaria a sua produção, até porque o país seria descoberto neste principiar do século, teria que ter tempo suficiente para conhecer e trabalhar as terras. Provavelmente, pelo fato das terras brasileiras e santomenses serem muito parecidas, houve uma competição durante muito tempo, em termos da produção açucareira, pois por volta de 1640 saiam em simultâneo, quer de São Tomé e quer no Brasil, barcos carregados de açúcar para outras regiões consumidoras deste produto. Certamente, a produção brasileira deveria ser muito superior à de São Tomé, para este período, mas não se sabe, devido a escassez de documentação em São Tomé, a cifra de tais 
diferenças $^{213}$. Como diz Furtado $(2007 ; 29)$, as terras americanas, referindo-se ao Brasil, no inicio do século XVI, era uma empresa completamente inviável, por esta época nenhum produto agrícola era objeto de comércio em grande escala para Europa. Principal produto seria o trigo, na qual dispunha de abundantes fontes de abastecimento dentro do continente ${ }^{214}$. Fazendo uma comparação dos países que produziram açúcar no Atlântico, fica evidente, pelo menos até o meado de século XVI, a superioridade produtiva de São Tomé frente a outras ilhas, neste período, quando provavelmente marcava o auge da produção de São Tomé, esta produziria 800.000 arrobas anuais, quando para os outros países a produção do mesmo artigo não ultrapassava a metade do que produzira São Tomé. Se levar em consideração todos os países, Cabo Verde é o que menos produzia o açúcar, as condições ecológicas deste país dificultavam a produção em escala semelhante a da produzida pelo São Tomé e Madeira, que ao contrário, possuía condições muitos adequadas do que necessitava para produção deste precioso bem.

\section{3 - Desenvolvimento técnico}

As técnicas utilizadas nas produções açucareiras se desenvolveram principalmente nas regiões onde o cultivo da cana bem como a produção do açúcar se processou de forma mais contínua e intensiva. Para tanto, elas foram importadas do Mediterrâneo, mais especificamente na Sicília, e também foi na região mediterrânica de importante produção açucareira e o primeiro espaço românico, onde se desenvolveu a tecnologia do açúcar e de onde a cana-de-açúcar com as suas técnicas foram transplantadas para Valência e mais tarde para a Madeira e São Tomé ${ }^{215}$. O recurso hídrico foi fundamental para todas as regiões produtoras destes produtos, onde facilita e viabiliza a dinâmica de todo o processo. Moenda é a técnica utilizada para moer a cana e o termo muitas das vezes é conhecido como casa de engenho, pelo fato de ser o motor de todo o processo produtivo - antes de tudo a cana precisa ser moída. De acordo com Alberto Vieira (1999), a moenda da cana utilizou-se vários meios técnicos comuns ao

\footnotetext{
${ }^{213}$ AHU-São Tomé, [ant. 1640], INFORMAÇÃO, do Conselho da Fazenda, sobre a ausência de resolução à denúncia anônima feita a um provedor da Alfândega acerca de uma nau que partiu do Brasil e outra de São Tomé, carregadas de açúcar e pão indo descarregar à Canária. Cx. 59, doc. 16.

214 FURTADO, Celso. Formação Econômica do Brasil. 32 ${ }^{\mathrm{a}}$ ed. São Paulo: Companhia Editora Nacional, 2005. p. 18.

215 NUNES, Naidea Nunes. O açúcar de cana na ilha da Madeira: do Mediterrâneo ao Atlântico Terminologia e tecnologia históricas e actuais da cultura açucareira. 2002. $778 \mathrm{f}$. Tese (Doutorado em Linguística Românica) - Faculdade de Artes e Humanidades, Universidade da Madeira, Funchal, 2002. p. 176.
} 
mundo mediterrânico, mas a disponibilidade de recursos hídricos conduziu a um maior aperfeiçoamento com a criação do primeiro engenho de água, na Madeira, patenteado em 1452 por Diogo de Teive ${ }^{216}$. O mesmo autor salienta que este processo resultou apenas nas áreas onde era possível dispor da força motriz da água, além de reforços no uso da força animal ou humana. Devido as escassez de dados, ficaria difícil esclarecer os aspectos técnicos deste engenho, o que se sabe é que o mesmo, em 1530, era uma mó movida à água, muito semelhante ao sistema usado no fabrico de azeite ${ }^{217}$.

Uma das questões que tem gerado polêmica prende-se com a evolução da tecnologia do fabrico do açúcar, concretamente a passagem do trapiche ao engenho de cilindros. O primitivo Trapettum era usado já na Roma antiga para triturar azeitonas e sumagre, sendo, segundo Plínio, inventado por Aristeu, Deus dos Pastores. Mas este se tornou um meio pouco eficaz nas grandes plantações, tendo-lhe sucedido o engenho de eixo e cilindros. É aqui que as opiniões divergem. Existe uma versão que aponta esta evolução como uma descoberta mediterrânica.

Depois da Sicília muitas técnicas são levadas para Ilha da Madeira, onde elas são aperfeiçoadas e depois transplantadas para outras regiões produtoras. Nesta região de acordo com muitos autores, pode-se verificar que até o meado do século XVI é a região que mais desenvolveu técnicas para a produção açucareira. Acredita-se ainda que talvez, a seleção desta região em destaque, se deveria mais pelo fato de possuir muitos documentos históricos relacionado à produção nesse país. Já em São Tomé e na ilha de Cabo Verde, embora ter produzido, em maior volume e durante um intervalo de tempo muito maior o açúcar, ela não se destacaria com países que desenvolveu muitas técnicas.

Os engenhos de eixo, provavelmente seriam uma inovação técnica mediterrânica, a historiografia castelhana atribui esta inovação a Gonzalo de Veloza, que teria apresentado o seu invento em 1515, na ilha de S. Domingos ${ }^{218}$. Muitos trabalhos apontam para a origem chinesa do engenho de dois cilindros, baseando assim nos estudos sobre a história do açúcar no Oriente, em particular, na Índia e na China, onde se encontra as mais antigas referências a esta tecnologia, usada para descaroçar o

\footnotetext{
${ }^{216}$ VIEIRA, Alberto. O Açúcar na Madeira: produção e comércio nos séculos XV a XVII. In: Producción y comercio del azúcar de caña en época preindustrial: Actas del Tercer Seminario Internacional. Granada: Diputación Provincial de Granada, 1993. p. 9.

${ }^{217}$ Ibid., p. 10

${ }^{218}$ NUNES, Naidea Nunes. O açúcar de cana na ilha da Madeira: do Mediterrâneo ao Atlântico Terminologia e tecnologia históricas e actuais da cultura açucareira. 2002. $778 \mathrm{f}$. Tese (Doutorado em Linguística Românica) - Faculdade de Artes e Humanidades, Universidade da Madeira, Funchal, 2002. p. 182.
} 
algodão e para fabricar o papel, que teria chegado à Europa, a partir de meados do século XV.

Certamente, na região do Atlântico, a ilha da Madeira foi a primeira a inovar em termos da tecnologia da produção açucareira, fato este que permitiu que as sucessivas ilhas da região importassem as primeiras técnicas e técnicos da referida ilha. A tecnologia primitiva da produção açucareira, nesta região é constituída pelo lagar e alçaprema, na base de prensa manual, e por trapichas de bestas, moinho com uma mó de pedra vertical movida por animais, correspondendo ao trappetum e ao torculum do Mediterrâneo, resultante da adaptação da tecnologia do vinho e do azeite ao açúcar ${ }^{219}$. Apesar de já ter havido uma inovação tecnológica avançada em termos de técnica de produção açucareira, as mesmas moendas usadas nos tempos primitivos dos engenhos para moldar cana-de-açúcar, ainda são usadas hoje como alternativas de moer milho e outros grãos que se achar necessário. Essas moendas são semelhantes aos moinhos de cereais, com duas pedras molares, e se encontra no uso em muitas regiões rurais da Madeira e em outras regiões, em todo Portugal. A prensa utilizada para espremer a cana, depois de esmagada, ainda hoje é utilizada, nessas regiões, para espremer o bagaço da uva e da azeitona, depois de pisada, extraindo totalmente o seu sumo em lagares, na produção familiar ou caseira.

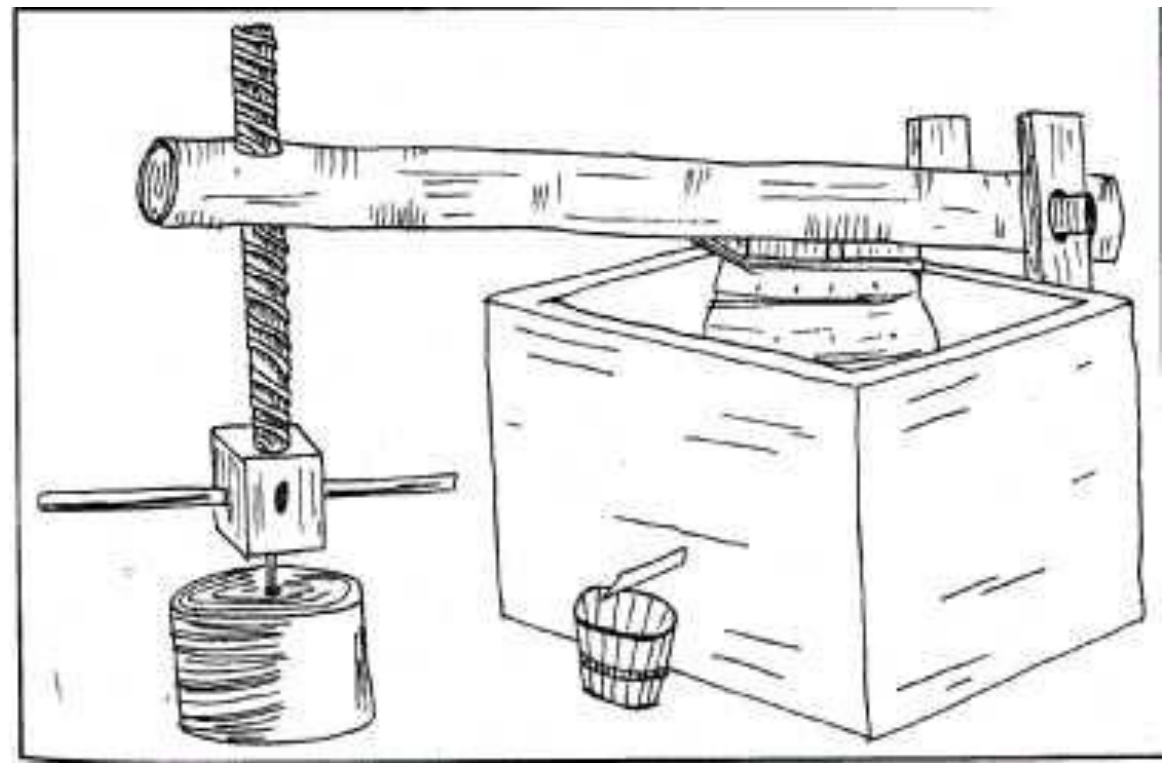

Figura 5: Alçaprema ou Lagar Almanjarra primitiva da Madeira ${ }^{220}$.

\footnotetext{
${ }^{219}$ Ibid., p. 171.

${ }^{220}$ Extraído de GOUVEIA, David Ferreira de. O açúcar da Madeira: a manufactura açucareira madeirense (1420-1550). Atlântico, Funchal, n. 4, p. 260-272, 1985. p. 265. Este alçaprema apresenta uma
} 
A utilização da força hidráulica, através da roda d'água, do tipo vertical, para a movimentação dos moinhos, foi a energia motriz mais recorrente nos primeiros engenhos, simultânea à força humana e à tração animal. A escolha de um ou outro tipo de energia dependia de fatores econômicos e geográficos. O uso do braço escravo ocorria de modo esparso, pois é sabido o baixo rendimento e a lentidão das moendas assim acionadas. No entanto, foi usado em grande escala na maioria das demais atividades dentro do engenho: preparo da terra, colheita, transporte de cana, outras tarefas de produção dentro da fábrica. Sem dúvida, São Tomé teria uma grande vantagem sobre todas as regiões produtoras do açúcar no principiar do século XV. Nesta região do Atlântico, havia todas as condições necessárias para a produção açucareira em grande escala. Transportado do Mediterrâneo, os engenhos foram se adaptando e ganhando formas alternativas e mais adequadas, consoante o fator produtivo disponível. De acordo com Nunes:

Como podemos verificar, o termo trapiche surge como termo simples e associado ao termo engenho, formando um termo composto engenho trapiche, que também ocorre em Granada. Este termo parece designar a tecnologia inovadora, desenvolvida na ilha da Madeira, da moenda de dois eixos de madeira horizontais, movida a bois, que coexistia com os engenhos de água, engenhos ou engenho d'asuquar, com a mesma tecnologia, mas movidos a água, e com o trapiche, moinho primitivo de roda de pedra vertical, movido por braços humanos ou por animais ${ }^{221}$.

Contudo, apesar da ilha da Madeira ser no Atlântico a primeira a experimentar as técnicas de produção, tudo indica que suas inovações técnicas não sofreram, ao longo do tempo, transformações importantes, sendo mesmo depois de terem surgidos os engenhos de água, os moinhos de cana continuavam rudimentares. Pode-se notar que essas técnicas de produção primitivas eram do século XV e estavam subdividas em quatro etapas: preparação das canas, moagem, cozimentos e purgação. Tudo indica que

reconstituição do primitivo trapiche de madeira usado no arquipélago madeirense, em que parece confundir as alçapremas com os trapiches. Nos tempos primitivos as canas eram espremidas em alçaprema (ou trapiches), em engenhos muito rudimentares, sendo os cilindros destes construídos algumas vezes de grossos troncos de til. A ideia de largar aparece, provavelmente de ser um alçaprema que conserva o seu suco a onde está sendo prensada a cana. Adaptado de: NUNES, Naidea Nunes. O açúcar de cana na ilha da Madeira: do Mediterrâneo ao Atlântico - Terminologia e tecnologia históricas e actuais da cultura açucareira. 2002. 778 f. Tese (Doutorado em Linguística Românica) Faculdade de Artes e Humanidades, Universidade da Madeira, Funchal, 2002. p. 172.

${ }^{221}$ NUNES, Naidea Nunes. O açúcar de cana na ilha da Madeira: do Mediterrâneo ao Atlântico Terminologia e tecnologia históricas e actuais da cultura açucareira. 2002. 778 f. Tese (Doutorado em Linguística Românica) - Faculdade de Artes e Humanidades, Universidade da Madeira, Funchal, 2002. p. 89. 
elas eram desenvolvidas em um mesmo recinto, sem grandes distanciamentos nas etapas existentes. Com a passar do tempo, essas técnicas foram evoluindo, e a necessidade de especialização aumentando. Por exemplo, nas técnicas primitivas, um mesmo trabalhador poderia executar, quando pudesse, mais de uma tarefa, ou era obrigado a conhecer todas as tarefas existentes. Com o passar do tempo, isso já não seria possível, pois, muitas tarefas antes feitas no mesmo recinto, muitas das vezes feitas pelos mesmos trabalhadores (de forma revezada), passaram a ser feitas em espaços diferentes, de modo que, muitos trabalharam em outras etapas, não conheciam as dinâmicas das etapas subsequentes $^{222}$.

De acordo com Ferlini ${ }^{223}$, as técnicas fundamentais utilizadas na Madeira já eram antes usadas nas oficinas sicilianas e posteriormente desenvolvidas em outras regiões produtoras do açúcar. Para a autora, três artes e três grandes problemas técnicos compunham a sequência operacional, sendo: moagem, cozimento e purgação. Cada uma dessas atividades era composta em operações particulares, isoladas, tornando assim a função exclusiva de um único trabalhador. Apesar de ter havido, desde muito cedo, essas atividades complexas na Sicília, a mesma continuou sendo, todavia, feita manualmente. Essa forma de trabalho mostrava-se aparentemente, mais viável uma vez que cada trabalhador se especializava em uma determinada tarefa, facilitando assim o processo produtivo, não obstante o aproveitamento do suco é muito reduzido. A vantagem da divisão ou especialização das tarefas seria pelo fato de acelerar o trabalho, mas não mudaria muito em termos da eficiência, pois as técnicas usadas ainda não foram capazes de aproveitar grande parte de suco extraído. Quanto mais as máquinas foram se aperfeiçoando, mais se conseguiria aproveitar um volume cada vez maior do suco de cana extraída na moagem. As moagens da Sicília utilizavam dois tipos de moinho: o de cereal, movido à roda d'água e o de prensa, movidos a força humana. Nesses, eram extraídos muito pouco quantidade do suco. A ampliação da produção exigia uma multiplicação das unidades de processamento ${ }^{224}$. O aproveitamento das técnicas, de alguma forma, estaria relacionado às exigências do mercado consumidor e às necessidades do produtor em produzir mais. Nos tempos mais remotos quando o

222 FERLINI, Vera Lucia Amaral. Uma fábrica colonial: trabalho e técnica nos engenhos brasileiros. In: História e tecnologia do açúcar. Coleção Memória 30. Funchal: Centro de Estudos de História do Atlântico, 2000. p. 185.

223 Ibid., p. 186.

${ }^{224}$ FERLINI, Vera Lucia Amaral. Uma fábrica colonial: trabalho e técnica nos engenhos brasileiros. In: História e tecnologia do açúcar. Coleção Memória 30. Funchal: Centro de Estudos de História do Atlântico, 2000. p. 187. 
açúcar não era ainda muito conhecido e consumido, se produzia manualmente e não havia grandes necessidades de técnicas muitos avançadas, mas à medida que o produto passou a ser conhecido e mais demandado, começara a surgir necessidade de inovações técnicas como forma de acelerar o processo produtivo. Os produtores, devido ao alto preço do produto, acabavam produzindo o que era demandado pelo mercado. Poucos tinham acesso ao mercado do açúcar, pelo fato deste pertencer na época ao produto de luxo, e uma produção mínima já supriria as necessidades dos antigos produtores. Porém, à medida que o produto foi sendo conhecido, ele passa a ser mais e mais demandado no mercado. De início, até que a demanda estimulou o preço do bem, fazendo com que este permanecesse alto, não obstante, quando se descobre outras regiões produtoras deste produto, gerou uma elasticidade muito grande na oferta do bem, fazendo cair o preço e, consequentemente, o lucro total. Se no período primitivo quando o açúcar era produzido de forma reduzido e manualmente, uma produção mínima poderia trazer grandes lucros por conta do alto preço do mesmo, à medida que os preços foram caindo, e lucros também, iam declinando-se considerar o nível produtivo constante. Provavelmente a solução desses problemas ao longo do tempo seria aumentar a produção, fazendo assim, com um preço menor, poder permanecer o nível lucrativo ou, de alguma forma, não fazê-lo declinar. Se a fatia do lucro depende da elasticidade da produção, maior produção, maior o lucro, assim quando o produto foi disseminado, a produção começou a ser em escala em um preço muito menor. Porém como as escalas produtivas cresceram consideravelmente, por conta das inovações surgidas, o lucro aumentou. A figura $\mathrm{x}$ mostra-nos como era a produção do açúcar na Sicília na época primitiva e que perdurou até a segunda metade século XVI. 


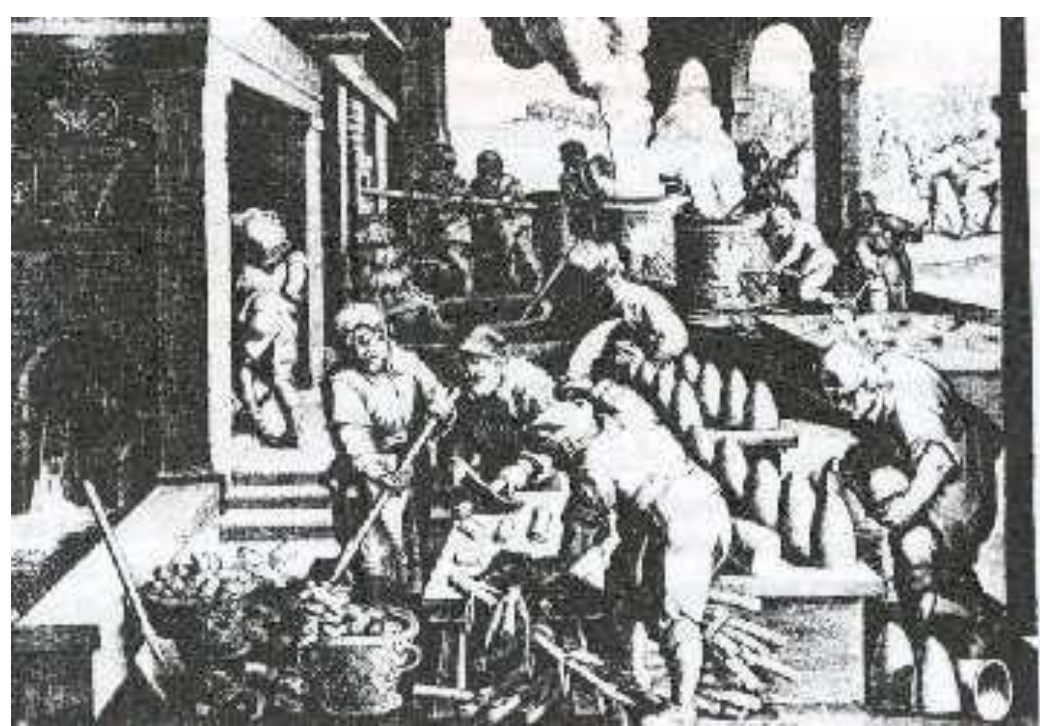

Figura 6: Engenho de Açúcar Siciliano da Segunda Metade do Século XVI. Fonte: Vera Lucia Amaral Ferlini ${ }^{225}$.

Nesta figura, apercebe-se que a produção é feita manualmente, e numa forma pouco especializada, como já foi mencionado. Nesta época, certamente, a necessidade de um nível produtivo alto não se fazia. Mas quando tais necessidades começaram a aumentar, incentivou a criação de novas técnicas como forma de suprir o nível produtivo maior necessário. Nesta, todos os trabalhadores conhecia um pouco de todas as tarefas executadas na produção. $\mathrm{O}$ aumento do nível produtivo levou ao aperfeiçoamento que consequentemente levou a divisão do trabalho. Assim sendo, a produção começou a exigir suportes adicionais no enquadramento das técnicas envolvidas. Se antes, a produção necessitava somente de homens e poucas ferramentas para desenvolver o processo produtivo, quando surge a necessidade de aumento na produção, as técnicas se aperfeiçoaram e os modelos passaram a incluir os animais e força motriz da água para impulsioná-la. Na figura 7 vamos ver moenda de força animal, que certamente seria mais produtivo que a técnica manual vista na figura anterior. Nesta técnica, além de produzir mais, vai reduzir o número de homens desenvolvendo tarefas.

\footnotetext{
${ }^{225}$ FERLINI, Vera Lucia Amaral. Uma fábrica colonial: trabalho e técnica nos engenhos brasileiros. In: História e tecnologia do açúcar. Coleção Memória 30. Funchal: Centro de Estudos de História do Atlântico, 2000.
} 


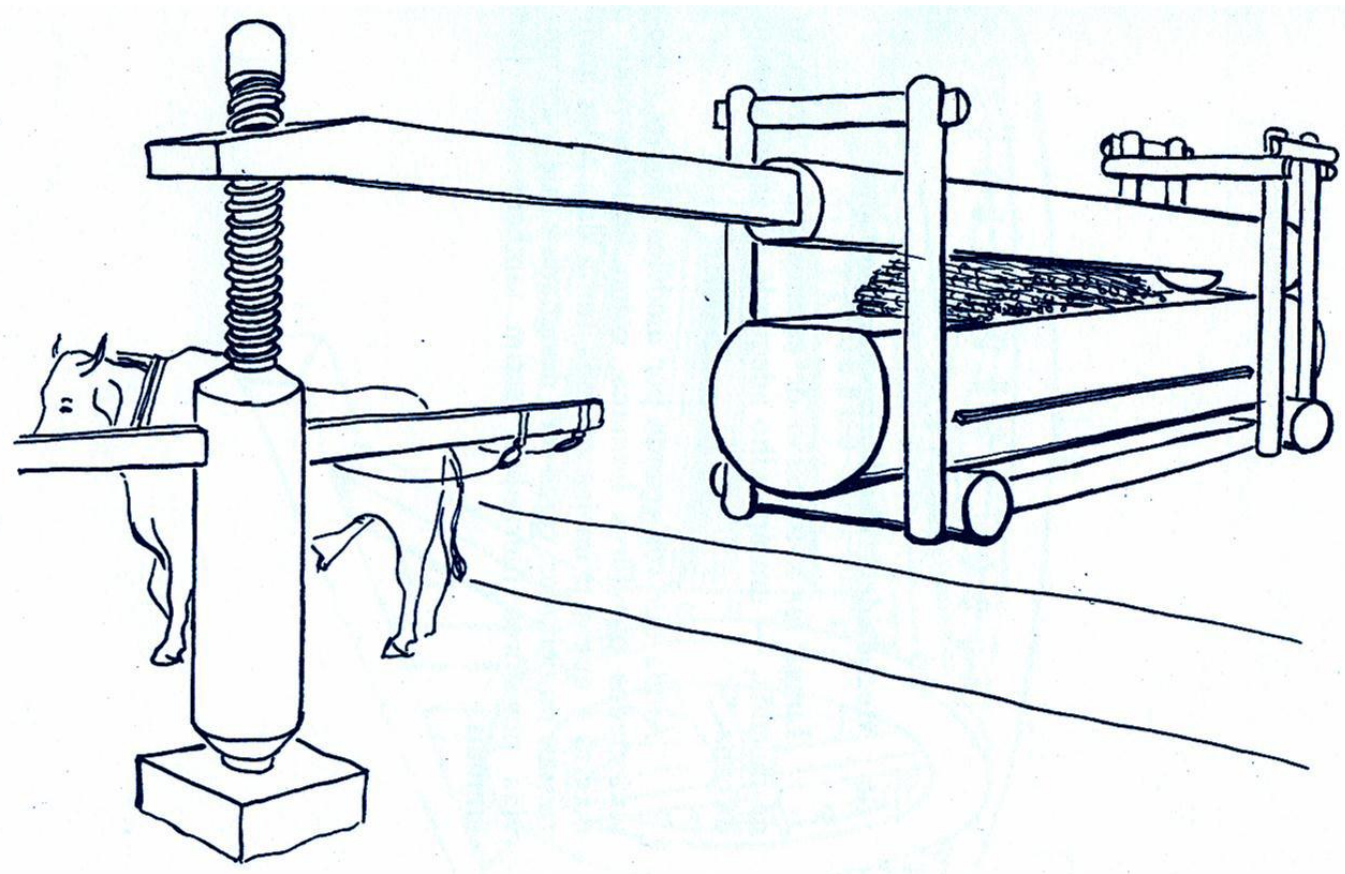

Figura 7: Moenda Primitiva a Forca Animal.

Fonte: Hamilton Fernandes ${ }^{226}$.

Na figura 7, vemos que o animal impulsiona uma alavanca para prensar cana. Apesar de ser uma técnica simples, usado com até dois animais, seria muito mais eficiente se fosse feito manualmente. Sabe-se que, em termos técnicos, a realidade de $\mathrm{S}$. Tomé aproxima-se mais da realidade antilhana do que da dos arquipélagos da Madeira e Canárias, pois a escravatura, na Madeira, não é dominante nesta produção, como em Cabo Verde, S. Tomé, Brasil e Antilhas ${ }^{227}$. O trabalho escravo começa a predominar no processo produtivo açucareiro por conta da necessidade da produção de escala que se fazia sentir. Se na época do auge nas regiões dos arquipélagos da Madeira e Canárias houvesse necessidade de uma escala produtiva equiparada aos produzidos em São Tomé e posteriormente no Brasil, certamente seria incluído o trabalho escravo em tais processos produtivos. O trabalho escravo foi fundamental para o processo de desenvolvimento da produção açucareira no atlântico e posteriormente em outras regiões produtoras. A introdução em massa do trabalho escravo no processo produto deste gênero devia ao fato de ser uma mão de obra barata e fácil de recrutar. Estima-se que o número de escravos capturados da África pelos Europeus entre 1451 e 1600

\footnotetext{
${ }^{226}$ Extraído de: FERNANDES, Hamilton. Açúcar e Álcool, ontem e hoje. Coleção Canavieira, n. 4. Rio de Janeiro, Instituto do Açúcar e do Álcool, 1971. p. 25.

${ }^{227}$ NUNES, Naidea Nunes. O açúcar de cana na ilha da Madeira: do Mediterrâneo ao Atlântico Terminologia e tecnologia históricas e actuais da cultura açucareira. 2002. $778 \mathrm{f}$. Tese (Doutorado em Linguística Românica) - Faculdade de Artes e Humanidades, Universidade da Madeira, Funchal, 2002.p. 178.
} 
girava em torno de aproximadamente 274.000. Desse número, a Europa e as ilhas do Atlântico receberam 149.000 escravos, a América Espanhola 75.000 e o Brasil, cerca de $50.000^{228}$. Apesar desse número ser uma aproximação do real, nos dá uma ideia de como a evolução produtiva açucareira se processou, exigindo cada vez mais suportes adicionais para facilitar a produção que se encontrava em demanda crescente no mercado internacional. As técnicas foram aperfeiçoando, mas o estilo de trabalho exigia ainda a força humana, pois apesar de algumas modificações nas técnicas produtivas, elas não avançaram muito. Grandes avanços técnicos e tecnológicos foram desenvolvidos no Brasil.

À medida que foram desenvolvendo as tecnologias da produção açucareira, apercebe-se que desenvolvia também técnicas diferentes, sendo umas com menos participação humanas e outras mais. Existiam vários tipos de moedas na produção: Movido à água, movido à força humana, movido à força animal e movido à força animal e humana. Durante séculos essas seriam as formas de moer cana para produção do açúcar, o que de certa forma, em todos os processos demandavam muito a mão de obra humana.

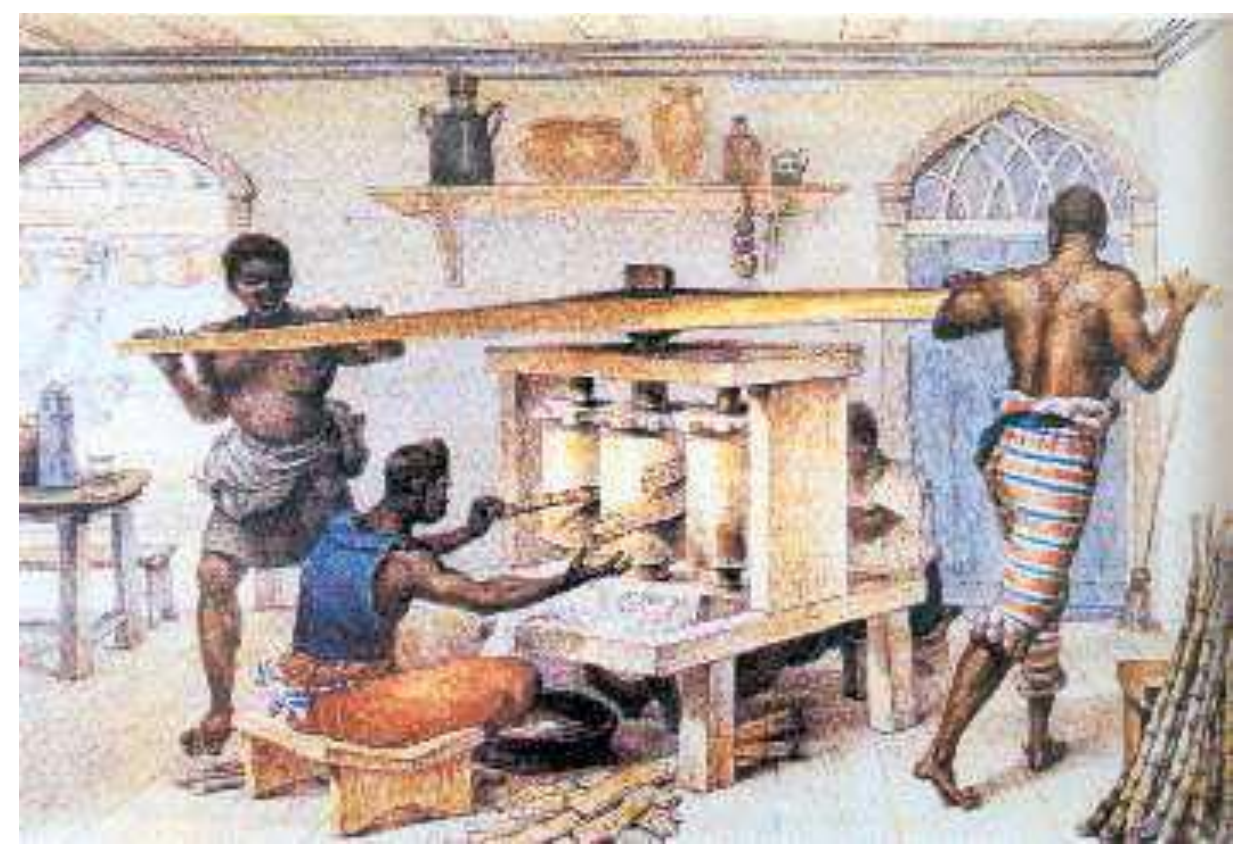

Figura 8: Moenda de três Cilindros Verticais a Movida à Força Humana Fonte: Jean-Baptiste Debret, 1822.

\footnotetext{
${ }^{228}$ OGOT, Bethwell Allan (Ed.). História geral da África, V: África do século XVI ao XVIII. Brasília: UNESCO, 2010. p. 9.
} 
Grandes inovações tecnológicas começaram a surgir nas ilhas de São Tomé e posteriormente no Brasil. Godinho destaca que em S. Tomé, até final do século XV, não utilizavam engenhos com casa da caldeira e nem tão pouco com casa de purgar, visto que, no seu testamento de 1499, o capitão Álvaro de Caminha deixara aos moços todo o cobre destinado aos engenhos, que eles teriam bem guardados até os haver e se fazer açúcar, pois então poderiam aproveitá-lo melhor, por venda ou aluguer. A descrição da ilha de São Tomé feita por Valentim Fernandes em Dezembro de 1506, elucida melhor toda a situação a situação ao afirmar que havia nesta ilha grandes canaviais de açúcar, sendo as canas maiores do que as da Madeira, delas fazem melaço, e daqui avante quer o capitão mandar fazer açúcar. Nessa descrição de Valentim Fernandes, esclarece-nos que em São Tomé foi desenvolvida tecnologias mais avançadas da época, depois da madeira, pois, nesta região as canas eram três vezes maiores que o da madeira, por outro lado o nível produtivo era muito maior que o da Madeira, havendo assim uma necessidade maior de técnicas que facilitasse a produção. Só para termos uma ideia, em momentos de auges da produção das duas ilhas, se neste período São Tomé produziria até 800.000 arrobas de açúcar, na ilha da Madeira, nos seus momentos de auge, a produção não chegaria nem na metade produzida em mesmo momento em São Tomé, ou seja, não chegaria, nem a 400.000 arrobas. Para Alberto Vieira, a mais antiga referência dos engenhos movidos a água, data em 1517 e se encontrava em São Tomé, na qual para este período já se produzia 100.000 arrobas de açúcar ${ }^{229}$. Para o mesmo autor, houve um grande incentivo por parte da coroa portuguesa em implantar mais números de engenhos nesta nova ilha, uma vez que em São Tomé tinham uma grande vantagem sobre todas as outras ilhas do Atlântico. Os motivos seriam que em São Tomé as plantações produziam muito mais que a ilha da Madeira, uma ilha que até o presente momento se mostrava mais próspera. Por possuir água em abundância, a maioria dos engenhos instalados em São Tomé era movido por força motriz de água.

\footnotetext{
${ }^{229}$ VIEIRA, Alberto. Portugal y las islas del Atlántico. Madrid: Editorial MAPFRE, 1992. p. 168.
} 


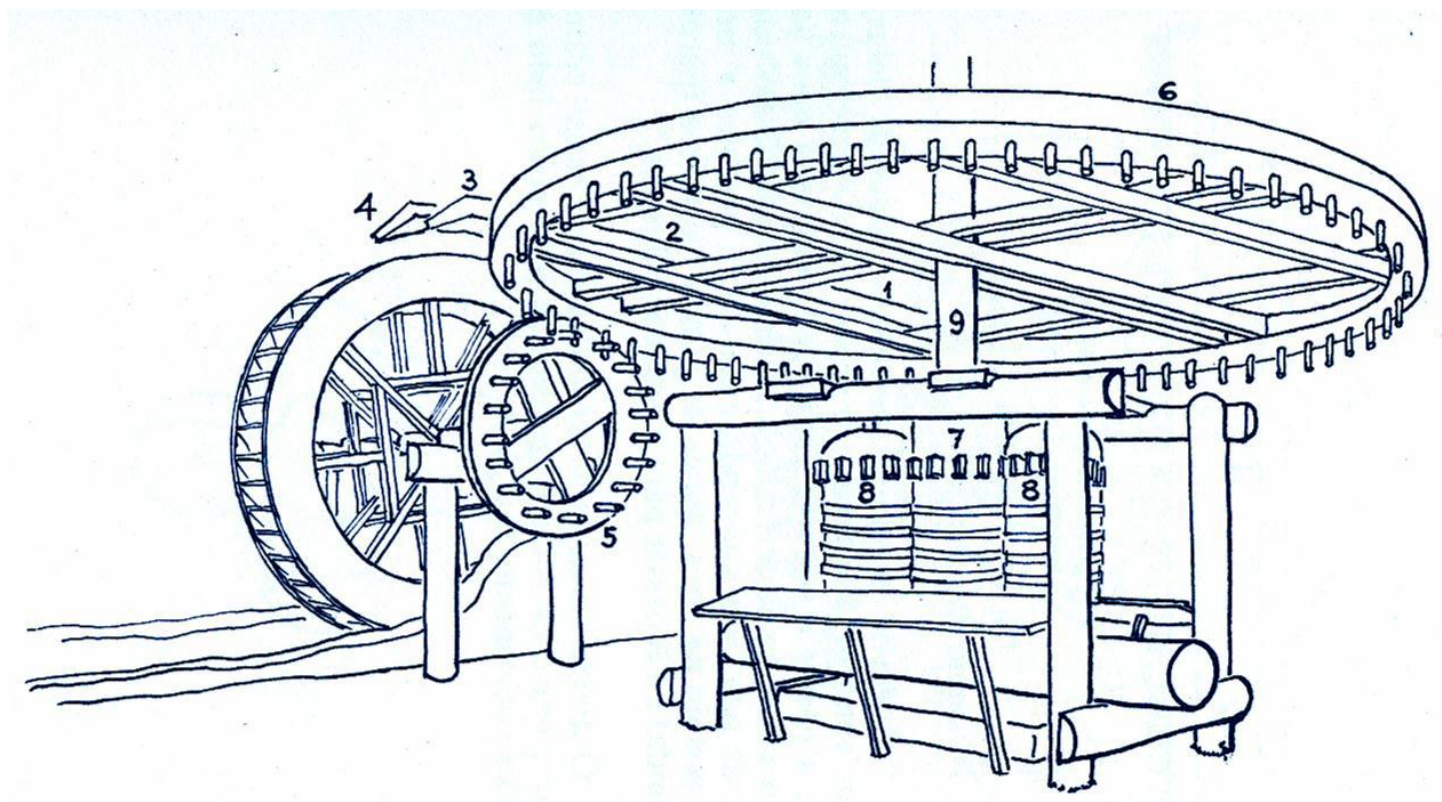

Figura 9: Moenda de Três Cilindros Movido por Força Hidráulica ${ }^{230}$.

O engenho movido a força motriz de água é o mais eficiente, em termos produtivos, das tecnologias primitivas existentes em São Tomé, além de trabalhar mais horas sem necessidade de parar o trabalho para substituir o trabalhador (caso fosse engenho movido a força humana) ou revezar os animais (caso fosse engenho movido a tração animal), o aproveitamento das caldas seriam maior. Este tipo de engenho é mais propício nas regiões onde abundam água corrente, para o caso de São Tomé isso se encaixaria quase perfeitamente, pois nas regiões onde não possui água suficiente para mover o engenho, esta prática seria substituído por força animal. Em meados do século XVI o piloto anônimo português se referia que em S. Tomé, existam muitos engenhos movidos à água, com os quais se moía e espremia a cana, sendo a calda obtida seriam lançados em grandes caldeiras, onde é fervido, sendo, em seguida, lançado em formas em que fazem pães de açúcar de 15 a 20 libras, purgados com cinza. Por outro lado, para o mesmo autor, muitos locais da ilha, onde não há água, os engenhos eram movidos a braços pelos negros ou utilizavam cavalos ${ }^{231}$.

\footnotetext{
${ }^{230}$ FERNANDES, Hamilton. Açúcar e Álcool, ontem e hoje. Coleção Canavieira, n. 4. Rio de Janeiro, Instituto do Açúcar e do Álcool, 1971.

${ }^{231}$ CALDEIRA, Arlindo Manuel. Viagens de um piloto português do século XVI à costa de África e a São Tomé. $1^{\mathrm{a}}$ ed. Lisboa: Gráfica Maiadouro, S.A. O mesmo texto foi traduzido do italiano por Mendo Trigoso e publicado por Reis Machado com o título: Viagem de Lisboa à ilha de S. Tomé. 2000, p. 65.
} 


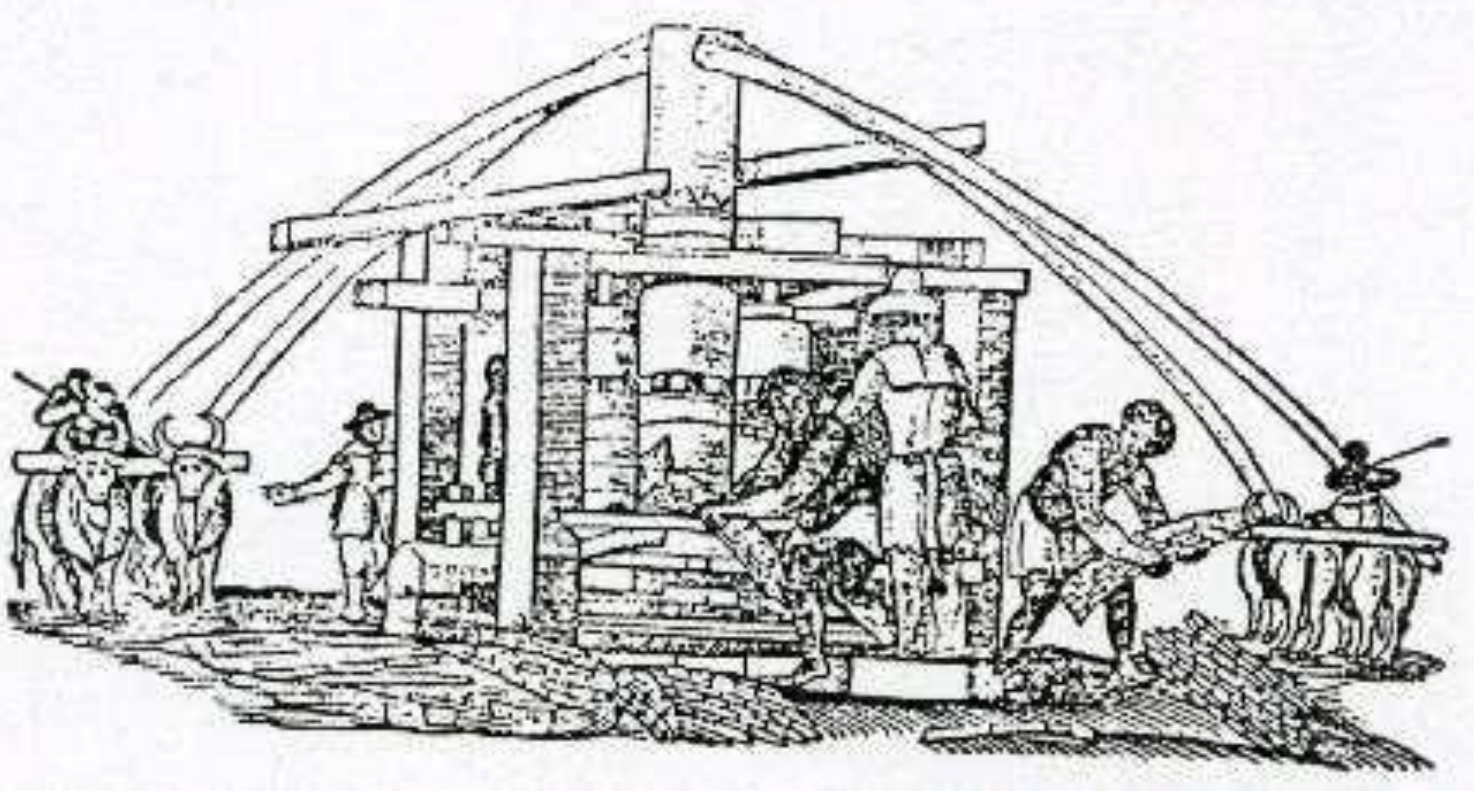

Figura 10: Engenho de três cilindros Verticais a Tração Animal, com Suporte Humano. Fonte: Jean-Baptiste Debret, 1822.

Na figura acima vemos que se trata de um engenho movido à tração animal, com suporte ou comando humano. Apercebe-se que em cada alavanca têm-se dois bois (que também poderá ser cavalos no lugar), e encima temos um homem controlando esse animal. Esse tipo de engenho representaria uma desvantagem em relação ao engenho movido à força motriz da água, enquanto este, em muitos momentos haveria necessidade de paralisar a produção por motivos de lesão ou até mesmo descanso de um animal ou até mesmo o homem, diferentemente no que ocorre no engenho da água, essa situação seria evitada, só paralisaria por falta de água, um fato que dificilmente ocorria porque, as regiões a ser instalado já seriam antes selecionadas, próximos aos riachos onde abundam água.

Ao longo do século XVI, embora houvesse algumas inovações mais avançadas, como moinho movido à força motriz da água, que apresentava uma maior eficiência ao engenho movido à força animal e humano, essas últimas continuaram sendo muito usadas em regiões de Açores, Canárias, Cabo Verde, S. Tomé e Brasil, tal como para a América espanhola. Elas seriam transplantadas da partir da Madeira, que possuía ambas as tecnologias em vigor: tecnologia primitiva quer a inovadora, coexistindo assim os moinhos rudimentares, movidos por bois e escravos, e os moinhos hidráulicos de dois eixos, que, no Brasil, evolui para três rolos verticais de madeira revestidos de ferro, 
permitindo extrair todo o sumo da cana, passando-a duas vezes entre os eixos e dispensando a prensa ${ }^{232}$.

A revolução industrial dos engenhos surge muito depois, aproximadamente no século XVIII, com a tecnologia da máquina a vapor. Quando os engenhos adquirem forma extremamente mais avançada, deixando de utilizar como força motora: animais, homem e água; é transformado em uma usina, denominados de fábricas industriais. Esses novos modelos são instalados para atender uma nova organização da produção, sendo que o senhor de engenho (um homem ligado a terra) deixa de ser o protagonista, passando agora a ser um homem da cidade, um industrial, um empresário de ideal burguês. Houve grande transformação no que se refere ao trabalho envolvido no processo produtivo, assim o escravo que antes trabalhava na força motriz do engenho, passa agora a trabalhar como um lavrador, um produtor da matéria-prima, degradando ainda mais o que se chamava de trabalho escravo, esse agora correndo maior no trabalho ${ }^{233}$.

De acordo com Holanda, a máquina a vapor da empresa açucareira, foi introduzida por volta de 1815, na Bahia, quando essa tecnologia já era usada e bem desenvolvida em boa parte Europa, e décadas após sua utilização da mesma nas Antilhas. O emprego da energia a vapor facilitou a produção, liberando os espaços de trabalho, bem como economizou mão de obra empregado em comparação com engenhos a tração humana. Além disso, liberou muitos animais, que antes eram usados, pois os mesmos tinham todo um cuidado com pastagens e alimentação, que muitas das vezes levaria muito tempo para evolução da produção como um todo. A nova forma de produzir o açúcar, em grande medida, exigia trabalhadores muito mais especializado e o o capital de investimento era muito maior, limitando desta forma, pessoas com pouco recurso a não se inserir no sistema. A rentabilidade do novo sistema era arrecadada ao médio longo prazo, uma vez que os capitais iniciais eram muito volumosos, fazendo com que os custos iniciais sejam muito superiores aos lucros iniciais. Além de existir

\footnotetext{
${ }^{232}$ NUNES, Naidea Nunes. O açúcar de cana na ilha da Madeira: do Mediterrâneo ao Atlântico Terminologia e tecnologia históricas e actuais da cultura açucareira. 2002. $778 \mathrm{f}$. Tese (Doutorado em Linguística Românica) - Faculdade de Artes e Humanidades, Universidade da Madeira, Funchal, 2002. p. 195.

${ }^{233}$ HOLANDA, Sergio Buarque de (Org.). A época colonial: administração, economia, sociedade. Rio de Janeiro: Bertrand Brasil, 2003. (História Geral da Civilização Brasileira; t. 1; v. 2).
} 
essa nova forma, as técnicas primitivas continuaram a ser utilizadas, e sendo excluídas nos sistemas paulatinamente ${ }^{234}$.

\begin{tabular}{|c|c|c|c|}
\hline \multicolumn{4}{|c|}{$\begin{array}{l}\text { Aproveitamento da Garapa em Função do Número de } \\
\text { Cilindros da Moenda }\end{array}$} \\
\hline $\mathrm{N}^{\circ}$ de Cilindro & Aproveitamento & Tipo & Século \\
\hline 2 & $20 \%$ & Horizontal & XV a XVI \\
\hline 3 & $35 \%$ & Horizontal /Vertical & XVI a XVII \\
\hline 5 & $90 \%$ & Vertical / Horizontal & XVII a XVIII \\
\hline 18 & $98 \%$ & Vertical / Horizontal & XVIII A XIX \\
\hline
\end{tabular}

Tabela 3: Aproveitamento da Garapa em Função do Número do Cilindro da Moenda.

Fonte: Adaptado de Alberto Vieira ${ }^{235}$.

Ao longo dos séculos, a moagem da cana sofreu grandes modificações, que em certa medida veio a melhorar a dinâmica da produção açucareira em termos da sua eficiência. A necessidade de uma maior, ou melhor, eficiência surge como meio de suprir a moagem de um volume maior de cana, saindo assim, dos mais arcaicos sistemas de cilindro para os mais avançados sistemas. Entre o final do século XV e durante todo XVII, foi uma época que mais se inovou em termos de tecnologia açucareira, nas quais significativas mudanças puderam ser notadas, para melhor e mais significativa eficácia produtiva. As mudanças de sistemas de cilindros passam a dominar todos os sistemas, sendo de tração animal, humana, vento e de água, destronando o pilão. Do simples mecanismo de cilindros duplos horizontais, evolui-se para os verticais, que no século XVII passam a ser triplos, que permitiu maior capacidade de moenda e aproveitamento do suco da cana. Com moenda de dois cilindros, o aproveitamento do suco da cana seria somente de $20 \%$, enquanto que a de três cilindros o aproveitamento subiria para $35 \%$. O aperfeiçoamento das tecnologias ao longo do tempo, veio ampliar ou acoplar até 18 cilindros em sistemas de tambor, tornando muito mais eficiente e útil a moenda. Até que chegassem os 18 cilindros, existiu o de cinco cilindros que tinha um aproveitamento de $90 \%$ dos sucos enquanto o mais inovador de 18 cilindros chegaria a um aproveitamento de aproximadamente $98 \%$ do caldo.

\footnotetext{
${ }^{234}$ HOLANDA, Sergio Buarque de (Org.). A época colonial: administração, economia, sociedade. Rio de Janeiro: Bertrand Brasil, 2003. (História Geral da Civilização Brasileira; t. 1; v. 2).

${ }^{235}$ Disponível em: <http://www.avieira.net>. Acesso em: 10 ago. 2016.
} 
Se por um lado, a eficiência do número de cilindros veio a acelerar o trabalho, por outro lado, essas técnicas vieram também a rentabilizar o volume do produto a ser produzido. Imaginemos se com duas toneladas de cana, em uma moagem de 2 cilindros, onde o aproveitamento do mesmo é de $20 \%$, se hipoteticamente esta moagem renderiam 200 litros de suco de cana, o de 18 cilindros, teríamos 980 litros. Na mesma lógica hipotética, se em cada 200 litros conseguiríamos 200 quilogramas de açúcar, em 980 litros, teríamos 980 quilogramas do mesmo produto. Se subtraírmos o resultado da moenda de 18 cilindros pelo da moenda de 2 cilindros, seria de uma perda de 780 quilogramas de açúcar, de uma tecnologia para outra.

No gráfico 5 pode ser visualizado a diferença em termos de rendimentos, relativamente diferente tipo de moenda, com o adicional em cilindros, sendo que quanto mais cilindros, menor desperdício do caldo da cana e, consequentemente, uma maior produtividade. Antes da existência das moendas com os respectivos cilindros, as tecnologias usadas para pisar cana eram de pedras molares, uma tecnologia muito primitiva, que provavelmente tivessem rendimentos mínimos. Os avanços tecnológicos vieram melhorar o tempo de trabalho, trazendo uma melhor eficácia em todo o processo produtivo, na medida em que se consegue em menos tempo produzir um volume muito maior de açúcar, facilitando toda a dinâmica produtiva: desde números de trabalhadores até a lenha usada no forno para cozimento de açúcar.

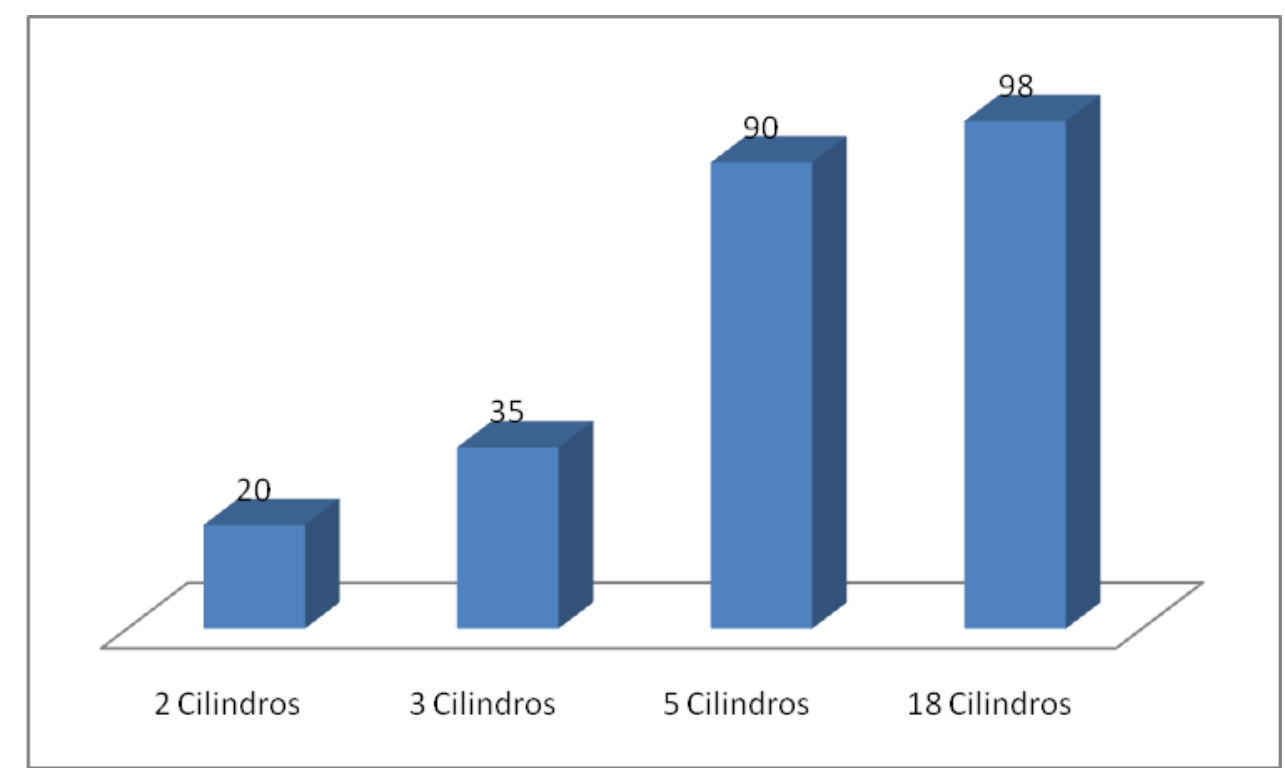

Gráfico 5: Diferença no rendimento em diferentes tipos de Moeda para o mesmo volume da cana-de-açúcar 
Muitos trabalhos de estudos sobre o açúcar na região do Atlântico se referem ao açúcar de São Tomé como a de uma péssima qualidade. Boa parte dos argumentos seguem o fato do açúcar de São Tomé ser vendido a um preço baixo e das outras regiões a um preço mais alto. Julgo que tais argumentos não seriam muito justificáveis, uma vez que o que determinava o preço do açúcar no mercado internacional foi o custo de produção e o nível de oferta. Certamente a qualidade do produto teria também o seu peso para a formulação do preço, mas para o caso de São Tomé Príncipe, parece que não obteve grandes impactos. Quando São Tomé começa a sua produção açucareira, faz reduzir a produção de muitas regiões antes produtoras deste artigo, uma situação que faz acreditar que o produto feito em São Tomé seria tão bom quanto de outras regiões, ou pelo contrário, teria uma qualidade bem melhor, uma vez que após início, leva muitos mercados consumidores a preferirem a mesma.

São Tomé não teve dificuldades com a obtenção de lenhas, e os custos com transporte seria uns dos poucos obstáculos para a produção deste produto, mas em compensação, os engenhos açucareiros de São Tomé eram construídos perto das regiões onde ofereciam muitas lenhas e águas, podendo certa medida, facilitar a produção e os custos totais. Devido as questões relacionado a lenha para cozimento de caldo de açúcar, muitos países, onde havia muita escassez de lenha, começaram a aproveita o bagaço da cana e através de um mecanismo de fornalha única, consegue-se alimentar as cinco caldeiras de cozimento. Esta técnica veio a facilitar os custos com a produção, fazendo reduzir o preço do produto no mercado.

Relativo ao açúcar molhado, muitos barcos chegaram nos destinos com este produto já molhada, não pelo fato dos mesmos serem feito molhados, mas sim, pelo fato de haver tempestades ou até mesmo ataques dos consórcios estrangeiros, holandeses e franceses $^{236}$.

Portanto, os custos elevados do açúcar estariam relacionados a vários fatores, dentre elas temos o custo com produção, custo com transporte, bem como o processo de cozimento que em certa medida teria ou não um resultado melhor ou não. Sabe-se que o açúcar de dois cozimentos seria melhor que a de um cozimento e isto requeria lenha,

\footnotetext{
236 ANTT/CC/2/134/146. Certidão em que consta que Gonçalo Lopes recebeu do almoxarife de São Tomé, por intermédio de Antão Pires, piloto da nau Santa Maria do Monte, 162 caixas e 1 caixão de açúcar onde vinham 1.025 arrobas e meia, as quais se molharam e arribaram a lagos e sendo pesadas se achou de açúcar limpo 843 arrobas e 7 arreteis e meio. 1526-07-23. Corpo Cronológico, Parte II, mç. 134, n. 146.
} 
para o caso das indústrias primitivas, e combustível, para o caso das produções industriais. Assim, para as regiões onde tinham as condições básicas necessárias em abundância para a produção, poderia vender o seu produto a um preço menor sem terem prejuízo, provavelmente seria o caso de São Tomé, pois no período de auge da produção açucareira, havia muitos países produzindo este bem e uma forma de ganhar mercado seria vender o produto ligeiramente a um preço menor, em correlação a média do mercado. 


\section{CONSIDERAÇÕES FINAIS}

Vários fatores são tangíveis ao processo que resultou na colonização das ilhas do Atlântico e, consequentemente, na ilha de São Tomé e Príncipe. Difícil afirmar que a descoberta se deu por acidente ou de forma planejada, uma vez que havia no período da descoberta, vários interesses entrelaçados que condenaram os países europeus, principalmente Espanha e Portugal, a se aventurarem nas outras regiões que não pertencessem ao continente europeu.

Havia grande interesse da coroa portuguesa que, provavelmente por questões econômicas fragilizadas, os induziram a traçarem metas, ao logo do século XV, como forma de sanar tais dificuldades. Essas metas contemplariam o descobrimento e exploração da costa africana - em particular a região norte, que era nesta época, centro e rotas das melhores e maiores especiarias, que também se estenderia, em grande medida, na expansão agrícola das ilhas do Atlântico e a abertura das rotas marítimas das Índias Orientais.

As condições encontradas nas ilhas do Atlântico e posteriormente nas Américas viabilizaram consideravelmente a estadia duradoura dos colonos europeus nas diferentes regiões instaladas. Para o caso de Portugal, a sorte foi de encontrar terras muito férteis, inicialmente no Atlântico - Madeira, pra implantar as suas iniciativas agrícolas comercias. Essa sorte não se deu em todas as ilhas encontradas, sendo na ilha de Cabo Verde e outras do Golfo da Guiné - Ano Bom; Ilha do Príncipe e a do Fernando Pó, não se mostrou (muito) viável nos seus maiores empreendimentos ali instalados. O açúcar desempenhou papel de grande importância no processo de desenvolvimento da economia de São Tomé, no período em estudo, e tais fenômenos não ocorreram isoladamente, sendo que no processo de colonização envolvia todas as atividades desde as terras boas, o clima favorável, habilidades dos colonizadores, mão de obra facilitadas, grosso modo, começando com as primeiras iniciativas de povoamento até o momento de grandes prosperidades das empresas agrícola.

No que se refere a organização territorial, inegável a marca deixada pelas instalações ali constatadas, sendo que a mesma teve grande repercussão, quer em regiões rurais, quanto em região urbana, buscando a lógica espacial de implantações dos engenhos e todas as estruturas desenvolvidas na dinâmica produtiva, sua arquitetura e relações com os núcleos urbanos, aeroporto e portos e para escoamento e comercialização de toda a produção e posteriormente a construção da cidade do país. 
Inicialmente, em São Tomé a cultura do açúcar era instalada na região noroeste, uma região que se mostrou pouco viável para tais práticas, particularmente durante o período em que a atividade açucareira contava como base da economia colonial. Durante todo o processo de desenvolvimento açucareiro, esta economia contou o com investimento do estado, sendo que a mesma exigia dos seus investidores um grande vulto financeiro, o que para iniciativa privada, muitas das vezes não era possível. Nesta, o Estado contava com alianças de grande financeiros (bancos e empresas) e comerciantes para pôr em prática tais investimentos, onde as necessidades industriais instalados nestas regiões eram satisfeitas e, em certa medida, renovadas e aperfeiçoadas.

Sem dúvida, a igreja teve o seu papel, direta ou indiretamente, no desenvolvimento das diferentes regiões. No processo da civilização, a igreja teve a sua participação na expansão marítima e no comércio, a sua intervenção mediava os interesses europeus e das outras civilizações, como forma de viabilizar o andamento e dinamizar em sentido profundo da produção. Neste tipo de empreendimento, como já se viu, exigia além de grandes traços de terras, um número grande de braços humanos que, na Europa, mostrava-se ser muito escasso, que por alternativa ia se buscar (forçadamente - contragosto) nas regiões africanas do norte - onde os abundavam. Essa iniciativa já estava enquadrava nos planos de Don João II, quando na tentativa de cristianização do continente africano em 1491, que juntaria com batismo de rei de jalofos e o próprio envio de missionários para o Benim.

O uso de mão de obra escrava foi um ponto facultativo em todo o processo produtivo, uma situação decorrente na sofisticação da produção e comercialização açucareiras. O tráfico de escravos da costa africana, estava estritamente relacionada a produção açucareira, sendo para estas produções, as tecnologias apresentadas, exigia mão de obra em massa como forma de reforço, atendendo que, durante muito tempo, as tecnologias usadas no atlântico e no Brasil ainda eram as tradicionais, boa parte deles importada do mediterrâneo sem grandes modificações a onde o braço humano era sua principal força, exemplo disso, seria a moenda de roda pedra vertical, em meado do século XVI era ainda era movida por tração força dos escravos.

Em São Tomé e no Brasil, que certamente dos primeiros países em inovações mais avançadas da tecnologia do açúcar, representa a casa da moenda de um engenho que também utiliza a roda de pedra do trapiche siciliano para a moagem movida por 
escravos. Esta seria uma forma de mostrar o quanto era indispensável a mão de obra escravo no processo de produção açucareiro, pois os escravos, tiveram uma participação total no processo: eles plantavam cana, cuidavam até que o mesmo atingiam idade madura, cortavam, preparavam a cana para moer, levavam para as moendas, espremiam o suco (caldo de cana), e preparavam até o produto final, além de participarem na produção direta dos engenhos, eles serviam os colonos em suas casas, tudo estava na dependência dos escravos.

Um dos maiores problemas envolvendo trabalho escravo estaria relacionado na alimentação, que eram de péssima qualidade, o que repercutiria negativamente, ao médio e longo prazo, para uma boa manutenção dos mesmos. Na primeira fase da colonização, a construção dos engenhos, em grande medida, apresentavam alguns problemas, pois a segurança dos escravos estava comprometida, ma medida que havia nenhum cuidado com os mesmos em tais ofícios, além dá alimentação totalmente precária.

A relação do trabalho escravo nas empreitadas açucareira estaria relacionada ao fato das empresas serem formadas pela grande propriedade de terra, na base de monocultura, por outro lado, em Portugal, no período em análise, vivia por uma escassez enorme de mão de obra: não havia população suficiente disponível para emigrar e também, adicionando a isso, as condições do clima aonde se processa a escravidão era muito parecido com as regiões nas quais eram providos tais escravos, assim solucionando o problema de adaptação dos mesmos.

A cultura da cana-de-açúcar constituiu uma das maiores e antigas atividades agroindustriais das ilhas de São Tomé e Príncipe. A descoberta dessas ilhas deveu-se ao interesse econômico que a coroa portuguesa mantinha através do comércio no continente africano, e também pelas viagens que os portugueses efetuavam no contexto dos descobrimentos, durante o século XV, por todo o oceano Atlântico. O arquipélago de São Tomé e Príncipe desde seu descobrimento mostrou-se favorável devido algumas características muito relevantes. Dentre essas características apresentadas, destaca-se a abundância de mão de obra que se encontrava na ilha, a localização privilegiada, técnica de produção e a fertilidade da terra. Na ilha de São Tomé, a partir dos anos posteriores ao seu descobrimento é introduzida a cultura da cana-de-açúcar que originou o estabelecimento de um número significativo de engenhos, sobretudo na costa nordeste, onde os terrenos e o clima facilitavam o mesmo estabelecimento. A principal massa populacional de São Tomé e Príncipe foram desenvolvidos em torno dos engenhos de 
açúcar, o que originou mais tarde a cidade capital do país. O cultivo da cana-de-açúcar e a produção de açúcar em São Tomé e Príncipe apresentavam uma estrutura baseada na organização pré-industrial com a especialização de tarefas agrícolas e artesanais, realizadas principalmente pelo trabalho escravo. Trabalho escravo possibilitou o progresso na produção, uma vez que a tecnologia utilizada era tradicional, transplantada do Mediterrâneo, onde o funcionamento era na base de uma roda de pedra vertical movida por escravos. É interessante aqui destacar que, nas regiões do atlântico, até aproximadamente século XVII, a produção em maior escala, era totalmente dependente do trabalho escravo, sendo esses que faziam as plantações da cana do açúcar, corte e os transportavam. Como já foram mencionados acima, os escravos deram grande suporte no engenho rudimentar existente na época. Mas com o passar do tempo, as técnicas foram sendo aperfeiçoadas e o sistema de trabalho ganhou em certa medida, um novo perfil. Se antes os escravos participavam diretamente em todo o processo, com o uso de moenda a cavalo e de força motriz de água, eles passam a participar em parte, mais especificamente nas plantações, corte de canas e carregamento de canas, desfazendo em certa medida do trabalho de força para moeda de cana.

As técnicas introduzidas na produção açucareira tiveram uma grande importância no desenvolvimento do todo o processo, por isso, neste trabalho, mereceu uma atenção especial. As referências à tecnologia histórica do açúcar nos espaços românicos do Mediterrâneo surgem das regiões como Sicília, Valência e Granada, pois é a partir desses que as tecnologias seriam desenvolvidas e transplantadas para os espaços açucareiros do Atlântico, incluindo a América, particularmente o Brasil. Como observou Nunes (2002; 698): para os Açores, Canárias, Cabo Verde, S. Tomé e Brasil, tal como para a América espanhola, são transplantadas, a partir da Madeira, quer a tecnologia primitiva quer a inovadora, coexistindo assim os moinhos rudimentares, movidos por bois e escravos, e os moinhos hidráulicos de dois eixos, que, no Brasil, evolui para três rolos verticais de madeira revestidos de ferro, permitindo extrair todo o sumo da cana, passando-a duas vezes entre os eixos e dispensando a prensa.

A alta do preço no mercado internacional também foi uns dos estímulos para a produção açucareira nas ilhas do atlântico, pois o produto era muito apreciado e cada vez mais conhecido no mercado internacional. A alta de preço e mão de obra barata foi um fator determinante para aumento da Renda da Coroa portuguesa. Devido os altos lucros obtidos nas primeiras instalações produtoras deste bem, juntando com 
experiências adquiridas neste processo, estimulou a implantação de mais e mais engenhos agroindústrias nas outras regiões conquistadas. 


\section{FONTES}

\section{ARQUIVO HISTÓRICO ULTRAMARINO:}

\section{[post. 1595, Abril, 24]}

REQUERIMENTO do [contratador das ilhas dos Açores], Cristóvão Pais, ao rei [D. Filipe I] solicitando que a sua causa fosse remetida a Francisco Giraldi ou a outro de seu serviço, para que o procurador da Fazenda Real concluísse a liquidação da sua conta, em virtude de há doze anos ter sido preso e a sua fazenda de pastel, trigo e açúcares vendida, em São Tomé e nas ilhas de Seis mil, e apesar de mandado libertar por D. Sebastião, não se procedera à liquidação da conta.

Obs.: m. est.; doc. cosido; anexo: requerimento.

AHU-São Tomé, cx. 1, doc. 2.

AHU_CU_070, Cx. 1, D. 2.

\section{[post. 1602, Novembro, 29]}

REQUERIMENTO dos contratadores do trato da ilha de São Tomé, ao rei [D. Filipe II] solicitando o pagamento dos direitos que lhes deviam ter sido pagos na feitoria da ilha aquando da saída dos açúcares, tendo eles feito petição ao alcaide-mor.

Obs.: m. est.; doc. cosido; anexo: instrumento em pública forma.

AHU-São Tomé, cx. 1, doc. 7.

AHU_CU_070, Cx. 1, D. 7.

1622, Maio, 31, [Cascais]

CARTA do ouvidor de Cascais, Luís de Aguiar Ribeiro, ao rei [Filipe III], sobre a chegada de um batel [vindo de São Tomé], com 18 homens que afirmavam que os holandeses os haviam atacado, roubado os navios, o açúcar, alguns escravos e morto o mestre e o condestável; informando que levara os escravos e um moleque dos sobreviventes à alfândega de Lisboa; referindo ainda o ataque dos soldados do capitão João Barbosa, do terço de D. Fradique, a uma nau de França que trazia vários moios de trigo.

Obs.: m. est.; anexo: auto.

AHU-São Tomé, cx. 1, doc. 68.

AHU_CU_070, Cx. 1, D. 63.

\section{[ant. 1623, Fevereiro, 21]}

REQUERIMENTO (cópia) do governador [da fortaleza de São Jorge] da Mina, [Manuel da Cunha e Teive], ao rei [D. Filipe III] solicitando farinha para as hóstias, cera para os ofícios divinos, azeite para a lamparina do Santíssimo Sacramento, uma botica para a enfermaria, lentilhas, passas de ameixas e açúcar, como todos os anos seguiam para a ilha e ficava registado na Casa da Índia, pedindo ainda um clérigo.

AHU-São Tomé, cx. 1, doc. 75.

AHU_CU_070, Cx. 1, D. 71.

\section{[ant. 1635, Janeiro, 16, Lisboa]}

INFORMAÇÃO [do secretário das Mercês e Expediente], Francisco de Lucena, sobre o comércio de açúcar [e tráfico de escravos] dos ingleses e dos holandeses, entre São Tomé e Londres, mencionando a colaboração de um criado italiano do governador Lourenço Pires de Távora, de um marinheiro chamado Prata e do contramestre Parola e a abertura de duas lojas inglesas na fortaleza portuguesa. 
Obs.: incluí auto de inquirição a Manuel Fernandes Prata e a Jorge Godinho, mencionando a participação do piloto português, Manuel Mendes, e do mercador do Funchal, Diogo Fernandes Branco, no comércio com os estrangeiros; anexo: auto de inquirição (cópia).

AHU-São Tomé, cx. 2, doc. 8 e 6.

AHU_CU_070, Cx. 2, D. 112.

\section{[ant. 1635, Setembro, 5, Lisboa]}

REQUERIMENTO do provedor e irmãos da Misericórdia [de Lisboa] ao rei [D. Filipe III] solicitando que, em prol do apoio aos pobres, a Misericórdia não tivesse de pagar, na feitoria de São Tomé, os direitos de saída dos açúcares dos engenhos e fazendas, ficando isenta, tal como os moradores daquela ilha.

Anexo: parecer.

AHU-São Tomé, cx. 2, doc. 19.

AHU_CU_070, Cx. 2, D. 123.

\section{6, Janeiro, 8, Lisboa}

CONSULTA do Conselho da Fazenda ao rei [D. Filipe III] sobre o requerimento do governador de São Tomé, António de Sousa de Carvalho, solicitando licença para embarcar para aquela ilha numa nau inglesa, em virtude de não haver portuguesas disponíveis, assegurando que a dita nau levaria piloto e mestre português e daria fiança aos direitos reais, querendo carregar açúcar e mercadorias para trazer a Lisboa, [sendo apta a resistir aos holandeses que navegavam entre Luango e cabo Lopo Gonçalves, capturando os navios mercadores].

Obs.: resolução da regente, duquesa de Mântua, D. Margarida de Sabóia; ver

AHU_CU_CONSULTAS DE PARTES, Cod. 41, fl. 58-58v; anexo: requerimento, informação,

Cartas régias (cópias de capítulo).

AHU-São Tomé, cx. 2, doc. 24 e 10.

AHU_CU_070, Cx. 2, D. 127.

\section{9, Junho, 23, Lisboa}

CONSULTA do Conselho da Fazenda ao rei [D. Filipe III] sobre o envio do dinheiro das presas e dos restos de açúcares derrotados da ilha de São Tomé pertencentes à Alfândega [de Lisboa]. Obs.: resolução da regente, duquesa de Mântua, D. Margarida de Sabóia.

AHU-São Tomé, cx. 2, doc. 38.

AHU_CU_070, Cx. 2, D. 142.

\section{9, Julho, 5, Lisboa}

CONSULTA do Conselho da Fazenda ao rei [D. Filipe III] sobre um papel que Tomás de Ybio Calderon escreveu à [regente] princesa Margarida, sugerindo que ordenasse ao governador de São Tomé para embargar a nau inglesa Frol de Maio, cujo mestre era Pedro Andrés, e uma nau holandesa do mestre Jacques Holandês, porque iam ambas Cascais carregar mercadorias de mercadores portugueses e ingleses para as levar à ilha de São

Tomé, trazendo de lá açúcar, fazendo isso com passaportes falsos.

AHU-São Tomé, cx. 2, doc. 39.

AHU_CU_070, Cx. 2, D. 143.

\section{[ant. 1640]}


INFORMAÇÃO [do Conselho da Fazenda] sobre a ausência de resolução à denúncia anónima feita a um provedor da Alfândega acerca de uma nau que partiu do Brasil e outra de São Tomé, carregadas de açúcar e pão indo descarregar à Canária.

AHU-São Tomé, cx. 59, doc. 16.

AHU_CU_070, Cx. 2, D. 145.

\section{0, Maio, 11, Lisboa}

CONSULTA do Conselho da Fazenda ao rei [D. Filipe III] sobre os requerimentos do governador nomeado para a ilha de São Tomé, Manuel Quaresma Carneiro, e do inglês Thomas Amy, residente em Lisboa; o primeiro solicitava licença para ir a São Tomé numa nau inglesa, por ser segura e trazer no regresso fazendas de lá para pagar os direitos, alegando que algo semelhante fora concedido ao governador António de Sousa de Carvalho e a outras duas naus; o segundo pedia licença para carregar sal e ir à Terra Nova buscar bacalhau e levá-lo ao Brasil e de lá trazer açúcar a Lisboa, pagando os direitos devidos; como a nau de Thomas Amy não chegou para levar o governador e o socorro a São Tomé e ao castelo de Axem, propôs-se o negócio a Guilherme Roles e a Jerónimo Onje.

Obs.: resolução da regente, duquesa de Mântua, D. Margarida de Sabóia; anexo: contrato

(Condições).

AHU-São Tomé, cx. 2, doc. 42.

AHU_CU_070, Cx. 2, D. 146.

\section{0, Novembro, 28, São Tomé}

REPRESENTAÇÃO dos oficiais da Câmara de São Tomé ao rei [D. Filipe III] solicitando permissão para que os navios ingleses fizessem resgate e vendessem escravos naquela ilha, pagando os direitos e comerciando o açúcar ao preço e risco dos portugueses, em virtude da diminuição dos direitos pagos à Fazenda Real, a queda de produção de açúcar e a consequente perda de engenhos, devido aos ataques holandeses aos navios portugueses de resgate, não havendo dinheiro para pagar as ordinárias ao Bispo, ao governador, ao clero e aos oficiais da Fazenda e Justiça; referindo que a nau inglesa se oferecera para levar novamente pólvora e munições ao capitão do castelo de Axem, mas necessitava de licença régia.

AHU-São Tomé, cx. 2, doc. 49.

AHU_CU_070, Cx. 2, D. 153.

[ant. 1635, Janeiro, 13]

REQUERIMENTO do capitão de navio São Filipe, Guilherme Maes, natural de Albuquerque, ao rei [D. Filipe III] solicitando licença e provisões necessárias para ir da ilha de Santiago de Cabo Verde à de São Tomé, para carregar a sua embarcação com açúcar, ou para o Brasil, em virtude de estar para seguir viagem para a ilha de Santiago para levar o novo governador, Jorge de Castilho, e os seus acompanhantes.

AHU-Cabo Verde, cx. 2, doc. 44.

AHU_CU_024, Cx. 2, D. 113.14 -

\section{0, Novembro, 29, São Tomé}

CARTA do governador de São Tomé, Manuel Quaresma Carneiro, ao rei [D. Filipe III] sobre as fortificações que o capitão do castelo de Axem fizera e a ameaça holandesa àquela praça; alertando que a pólvora e as munições que trouxera eram insuficientes, pedindo armas, munições, mantimentos e soldados voluntários, mas não degredados, devido à sua falta de honra; dando conta da falta de rendimentos da ilha, em direitos e 
em produção de açúcar, pela falta de chuva e de escravos, não havendo como pagar as ordinárias; informando que dera licença de comércio aos ingleses em troca de levarem socorro a Axem, porque os ataques holandeses e franceses o impediam de o levar, conforme podia atestar o ex-governador Lourenço Pires de Távora; declarando as razões porque não provera os ofícios de escrivão do Almoxarifado e Contos em António Ferreira e de feitor em João da Silva.

AHU-São Tomé, cx. 2, doc. 50.

AHU_CU_070, Cx. 2, D. 154.

\section{[ant. 1641, Novembro, 6]}

MEMÓRIA do nomeado para governador de São Tomé, Lourenço Pires de Távora, sobre os descaminhos ocorridos na Fazenda Real daquela ilha, nos direitos das naus estrangeiras que iam ali carregar açúcar e comerciar escravos, referindo que o almoxarife e recebedor Francisco de Alva Brandão, já falecido, e seus herdeiros não haviam prestado contas.

Obs.: m. est.

AHU-São Tomé, cx. 2, doc. 63.

AHU_CU_070, Cx. 2, D. 162.

\section{7, Setembro, 16, Lisboa}

CONSULTA do Conselho Ultramarino ao rei D. João IV sobre o pedido do provedor e irmãos da Misericórdia de Lisboa para que o mercador inglês, Roberto Coque, obtivesse licença para mandar dois navios ingleses a São Tomé, carregar os açúcares pertencentes à Misericórdia, entre as fazendas que foram de Simoa Godinha e António Faleiro de Abreu, pagando os direitos devidos na alfândega.

Obs.: m. est.; ver AHU_CU_CONSULTAS DE PARTES, Cod. 278, fl. 152v-153v.

AHU-São Tomé, cx. 2, doc. 77.

AHU_CU_070, Cx. 2, D. 177.

\section{1, Setembro, 11, Lisboa}

CONSULTA do Conselho Ultramarino ao rei D. João IV sobre o requerimento [do mercador inglês] Roberto Coque, e de João Nunes, solicitando licença para enviar o navio francês Pina a São Tomé, em companhia do governador Cristóvão de Barros Rego, para carregar uma partida de açúcar, caso não houvesse navio português.

Obs.: ver AHU_CU_CONSULTAS DE PARTES, Cod. 278, fl. 404-404v.

AHU-São Tomé, cx. 2, doc. 87.

AHU_CU_070, Cx. 2, D. 188.

1653, Fevereiro, 1, Lisboa

CONSULTA do Conselho Ultramarino ao rei D. João IV sobre o requerimento do francês Miguel Dantes, vizinho de Baiona, solicitando licença para levar a nau Esperança a São Tomé, fretada ao mercador do Porto, Estevão de Brus, com mareação francesa, para carregar açúcar e frutos da terra e trazê-los a Lisboa, pagando os direitos devidos.

Obs.: ver AHU_CU_CONSULTAS DE PARTES, Cod. 45, fl. 102v.

AHU-São Tomé, cx. 2, doc. 91.

AHU_CU_070, Cx. 2, D. 192.

1653, Setembro, 10, Lisboa 
CONSULTA do Conselho Ultramarino ao rei D. João IV sobre a carta do governador de São Tomé, Cristóvão de Barros Rego, acerca da falta de lucro com os açúcares da ilha, excepto se fossem vendidos a dinheiro aos navios que paravam naquele porto.

Obs.: ver AHU_CU_CONSULTAS MISTAS, Cod. 15, fl. 66.

AHU-São Tomé, cx. 2, doc. 94.

AHU_CU_070, Cx. 2, D. 195.

\section{3, Setembro, 10, Lisboa}

CONSULTA do Conselho Ultramarino ao rei D. João IV sobre a carta do governador de São Tomé, Cristóvão de Barros Rego, propondo a venda dos açúcares da ilha a naus estrangeiras, a troco de dinheiro, devido à ausência ou incapacidade das naus portuguesas, e assim poder pagar os ordenados aos soldados e as ordinárias ao clero.

Obs.: ver AHU_CU_CONSULTAS MISTAS, Cod. 15, fl. 65v.

AHU-São Tomé, cx. 2, doc. 95.

AHU_CU_070, Cx. 2, D. 196.

\section{3, Setembro, 10, Lisboa}

CONSULTA do Conselho Ultramarino ao rei D. João IV sobre a carta do governador de São Tomé, Cristóvão de Barros Rego, acerca de ter pago as ordinárias ao clero em açúcar e dinheiro, devido à falta de verbas, afirmando que o clero queria tudo em dinheiro como no tempo dos contratos da ilha.

Obs.: ver AHU_CU_CONSULTAS MISTAS, Cod. 15, fl. 65v-66.

AHU-São Tomé, cx. 2, doc. 96.

AHU_CU_070, Cx. 2, D. 197.

\section{4, Novembro, 18, Almeirim}

DECRETO do rei D. João IV ordenando ao Conselho Ultramarino para analisar a consulta da Junta da Companhia Geral [de 12 de Novembro de 1654], sobre [as cartas de Duarte e Jerónimo Nunes da Costa, acerca da chegada de dois] navios a Hamburgo, que foram carregar açúcares a São Tomé [com o ouro obtido no comércio realizado na costa da Guiné e da Mina] e voltaram directamente às suas terras com o consentimento dos mercadores da ilha, [sem pagar os direitos alfandegários, e levando à descida do preço do açúcar do Brasil].

Anexo: consulta e carta (cópia).

AHU-São Tomé, cx. 2, doc. 109.

AHU_CU_070, Cx. 2, D. 210.

\section{7, Maio, 16, São Tomé}

CARTA do governador de São Tomé, Carlos de Nápoles, ao rei [D. Afonso VI] solicitando a revisão das condições do contrato de São Tomé de Sebastião Lamberto e outros, devido à falta de comércio de escravos e de navios estrangeiros vindos da Mina; alertando que a diminuta taxa dos açúcares e o alto preço das fazendas do contrato acabariam por parar os engenhos; pedindo que os moradores de São Tomé, tal como os de Angola e Cabo Verde, pudessem comerciar com os navios castelhanos das Índias.

Anexo: carta.

AHU-São Tomé, cx. 2, doc. 120.

AHU_CU_070, Cx. 2, D. 222.

1657, Setembro, 6, Lisboa

CONSULTA do Conselho da Fazenda ao rei [D. Afonso VI] sobre o navio holandês Nicolau, fretado pelos contratadores de São Tomé, ter sido tomado por outro navio 
holandês e entregue a piratas, tendo o procurador do povo de São Tomé descoberto que o capitão holandês que os tomara levara anteriormente carga de açúcar para a Holanda por conta dos contratadores de São Tomé; o conselho da Fazenda mandara prender os contratadores

Sebastião Lamberto, Belchior Borray e Pedro Estalpart, confiscar os seus bens e tirar devassa.

Obs.: resolução da regente D. Luísa de Gusmão.

AHU-São Tomé, cx. 2, doc. 122.

AHU_CU_070, Cx. 2, D. 224.

1661, Janeiro, 12, Lisboa

CONSULTA do Conselho Ultramarino ao rei [D. Afonso VI] sobre as cartas do governador de São Tomé, Carlos de Nápoles, solicitando a entrada de navios das Índias de Castela naquela ilha, porque os moradores estavam ressentidos com as condições do contrato, porque lhes taxavam os açúcares e as fazendas, e não tinham outra saída para os produtos.

Obs.: resolução da regente D. Luísa de Gusmão; ver AHU_CU_CONSULTAS MISTAS,

Cod. 16, fl. 3.

AHU-São Tomé, cx. 2, doc. 131.

AHU_CU_070, Cx. 3, D. 233.

1661, Janeiro, 29, Lisboa

CONSULTA do Conselho Ultramarino ao rei [D. Afonso VI] sobre o requerimento do contratador de São Tomé, Sebastião Lamberto, solicitando que um oficial de justiça notificasse o mestre da embarcação da nau que ele mandaria à ilha de São Tomé para carregar algodão para trazer a Lisboa, para que não levasse mais de vinte negros do governador cessante, Carlos de Nápoles, sob pena de prisão, porque sabia que o governador queria levar muitos escravos a Cabo Verde para os vender a naus castelhanas, ficando a nau sem espaço para o algodão, a produção de açúcar sem escravos e a nau vazia ao chegar à alfandega.

Obs.: resolução da regente D. Luísa de Gusmão; ver AHU_CU_CONSULTAS DE PARTES,

Cod. 46, fl. 161v; anexo: despacho.

AHU-São Tomé, cx. 2, doc. 136 e 140.

AHU_CU_070, Cx. 3, D. 239.

1667, Outubro, 17, Lisboa

CONSULTA do Conselho Ultramarino ao rei [D. Afonso VI] sobre o pedido do provedor e irmãos da Santa Casa da Misericórdia de Lisboa, solicitando provisão que ordenasse aos oficiais das embarcações que fossem a São Tomé que a primeira carga de açúcar que carregassem fosse a da Santa Casa, sem impedimento dos governadores ou oficiais de justiça.

Obs.: resolução do infante regente D. Pedro; ver AHU_CU_CONSULTAS DE PARTES,

Cod. 46, fl. 408v.

AHU-São Tomé, cx. 2, doc. 152.

AHU_CU_070, Cx. 3, D. 251.

1683, Agosto, 2, São Tomé 
CARTA do ouvidor-geral de São Tomé, Domingos Quaresma Martins, ao regente [D. Pedro] sobre Fernão Soares de Noronha ter regressado à ilha como sargento-mor e provedor das fazendas dos defuntos e ausentes, anos depois de ter fugido dali por ser acusado de vários crimes e devassado pelo desembargador sindicante, Manuel Dias Raposo; avisando que o prendera, fizera devassa e o enviara a [Lisboa]; informando que, por provisão da Câmara e do alcaide João Alves da Cunha, retirara António Fernandes de Carvalho do cargo de provedor da Fazenda Real, porque era incapaz; afirmando que o rendimento da alfândega e dos açúcares não permitiam fazer pagamentos, solicitando por isso liberdades aos mercadores.

AHU-São Tomé, cx. 3, doc. 66.

AHU_CU_070, Cx. 3, D. 325.

\section{6, Dezembro, 9, Amesterdão}

CARTA [do agente de Portugal na Holanda], Jerónimo Nunes da Costa, ao rei [D. Pedro II] sobre os holandeses não respeitarem [os artigos de paz estabelecidos com Portugal], tomando o patacho que o signatário enviara, com o mestre Gabriel Vaz de Oliveira, carregar os açúcares que comprara à Casa da Misericórdia de São Tomé, sendo depois obrigado a enviar o navio a Cabo Verde, por Inglaterra, e negociar com o governador de lá, Inácio de Franca Barbosa, uma patente em como o barco e as fazendas eram de portugueses.

AHU-São Tomé, cx. 3, doc. 81.

AHU_CU_070, Cx. 3, D. 340.

\section{2, Março, 11, Lisboa}

CONSULTA do Conselho Ultramarino ao rei D. Pedro II sobre o requerimento do senhorio do navio São Nicolau e São Pedro, Nicolau Pedro, solicitando biscoito e pólvora para a viagem e mareação que ia fazer a São Tomé para levar o governador Ambrósio Pereira de Berredo [e Castro] e o ouvidor-geral [Tomás de Matos Girão], em consequência do pedido de embarcação feito pelo governador [e consultado a 17 de Janeiro de 1692]; referindo que [a consulta de 3 de Março de 1692] fixara o valor do frete e das despesas com soldos, pólvora, munições, mantimentos, apetrechos e gente, levando em conta o desvio que teria de fazer da Bahia, onde ia carregar açúcar e tabaco, num barco tão grande e fora da frota do Brasil.

Obs.: ver AHU_CU_CONSULTAS DE PARTES, Cod. 50, fl. 99v-100, 85-85v e 164v165v; anexo: consultas e bilhete.

AHU-São Tomé, cx. 3, doc. 117.

AHU_CU_070, Cx. 4, D. 367.

\section{6, Julho, 30, Lisboa}

CONSULTA do Conselho Ultramarino ao rei D. Pedro II sobre o requerimento de Jerónimo Nunes da Costa, morador em Amesterdão, solicitando ordens para que a Câmara de São Tomé obrigasse os moradores da ilha a pagar-lhe as várias partidas de açúcar que lhes comprara no passado, porque os vendedores e os seus herdeiros tinham falido e vendido o açúcar a navios estrangeiros, lesando-o no valor das dívidas e dos fretes dos navios.

AHU-São Tomé, cx. 3, doc. 138.

AHU_CU_070, Cx. 4, D. 388.

\section{8, Dezembro, 7, Lisboa}

CARTA DE CONFIRMAÇÃO (cópia) do rei [D. João III] ao privilégio de liberdade dado porD. Manuel I aos primeiros moradores da ilha de São Tomé, a 10 de Agosto de 
1520, para que não fossem presos, excepto sob fiança em crimes de morte, tanto homens como mulheres, ordenando que os mulatos de bem e casados pudessem exercer os ofícios do concelho, segundo o seu merecimento.

Anexo: provisão (cópia).

AHU-São Tomé, cx. 1, doc. 1.

AHU_CU_070, Cx. 1, D. 1.

[ant. 1600, Novembro, 24]

CARTA [dos oficiais] da Casa da Índia, sobre o atraso da embarcação dos feitores e moradores de São Tomé, a cargo do contratador de escravos da Costa da Mina, Francisco Revelasco, tendo o falecido vedor da Fazenda, João Gomes da Silva, provido os cargos conforme o regimento para assim conservar a feitoria do contrato.

Obs.: m. est.; no mesmo suporte consta um requerimento do moço da Câmara de Sua Majestade, soldado na fortaleza de São Jorge da Mina, Cosme Vieira.

AHU-São Tomé, cx. 1, doc. 4.

AHU_CU_070, Cx. 1, D. 3.

\section{[post. 1600, Dezembro, 25, São Tomé]}

CARTAS (traslados) do cabido, da Câmara e do Bispo de São Tomé, [ Vilanova], sobre o levantamento do escravo [Amador], em 1595, o ataque [dos holandeses] comandados por Pieter van der Does, a destruição das igrejas, a rendição do governador D. Fernando de Meneses, a eleição de Jerónimo Barbosa da Cunha como alcaide-mor, a morte do comandante holandês e a eleição de Pero Fernandes Barbosa para arcediago da Sé; [contém cartas de [Filipe II] sobre o auxílio a dar a Pernambuco e à Bahia face ao risco de um ataque holandês e o envio de um novo governador para São Tomé, com um Engenheiro para projetar a reedificação da fortaleza e da cidade].

Obs.: publ. em BRÁSIO, António (colig. e anot.) - MMA: África Ocidental (15701599). Lisboa: Agência Geral do Ultramar, 1953. Vol. III, doc. 171, 172 e 173, p. 598604 e IDEM - MMA: África Ocidental (1600-1610). Lisboa: Agência Geral do Ultramar, 1955. Vol. V, doc. 2, 5, 6 e 9, p. 6, 9-12 e 17-[19]; anexo: informação.

AHU-São Tomé, cx. 1, doc. 3.

AHU_CU_070, Cx. 1, D. 4.

\section{[ant. 1601, Dezembro, 31]}

REQUERIMENTO do aposentador da corte, Pero Bugalho, ao rei [D. Filipe II] solicitando provisão para receber dois escravos como complemento ao ordenado, pagos na ilha de São Tomé pelo rendimento das rendas de Sua Majestade, descontando-se a verba que devia pelo tempo que serviu de almoxarife na imposição dos vinhos, alegando que a mesma graça fora concedida ao seu companheiro de ofício Pantaleão Correia.

Obs.: m. est.; doc. cosido; anexo: requerimento e certidão.

AHU-São Tomé, cx. 1, doc. 5.

\section{2, Abril, 18, [Valladolid]}

CARTA RÉGIA (cópia de capítulo) do rei [Filipe II] concedendo perdão a quem semeara, no passado, gengibre na ilha de São Tomé e exigindo licença para aquela cultura no presente; encomendando ao vice-rei [de Portugal, marquês de Castelo Rodrigo, D. Cristóvão de Moura e Távora] que averiguasse, com a Junta da Fazenda, a conveniência de se dar aquela licença em São Tomé e no Brasil, pagando os mesmos direitos que se pagavam do que vinha da Índia.

Obs.: m. est. AHU-São Tomé, cx. 1, doc. 6. 
AHU_CU_070, Cx. 1, D.6 .

1603, Julho, 8

ESCRITO do [secretário do governo de Portugal], Cristóvão Soares, sobre as informações recolhidas pelo vice-rei [de Portugal, marquês de Castelo Rodrigo, D. Cristóvão de Moura e Távora], acerca da carta régia de [D. Filipe II] de 22 de Janeiro de 1603, onde ordenava que não se permitisse aos holandeses a construção de fortes na ilha do Príncipe e se lhes limitasse o comércio.

Obs.: publ. no "Boletim" do AHC, Vol. 1, 1950, pág. 225 e 226; anexo: carta régia (cópia de capítulo).

AHU-São Tomé, cx. 1, doc. 8.

AHU_CU_070, Cx. 1, D. 8.

[post. 1606, Julho, 17]

REQUERIMENTO de António Carneiro da Silva ao rei [Filipe II], solicitando licença para mandar vir de São Tomé dois escravos, um homem e uma mulher, para o serviço de sua casa.

Obs.: m. est.; anexo: bilhete.

AHU-São Tomé, cx. 1, doc. 9.

AHU_CU_070, Cx. 1, D. 9.

\section{9 - 1606, Novembro, 18, Lisboa}

CONSULTA do Conselho da Índia ao rei [Filipe II], sobre o requerimento de António de Barros, solicitando o cargo de escrivão da caravela que ia à Costa da Mina, capitaneada por João Pais Freire.

Obs.: m. est.

AHU-São Tomé, cx. 1, doc. 10.

AHU_CU_070, Cx. 1, D. 10.

[ant. 1607, Janeiro, 23]

REQUERIMENTO dos escrivães das caravelas, Custódio Fernandes e Salvador de Abreu, ao rei [D. Filipe II] solicitando ajuda de custo para a embarcação em que iam à Costa da Mina.

Obs.: m. est.; doc. cosido; anexo: provisão.

AHU-São Tomé, cx. 1, doc. 11.

AHU_CU_070, Cx. 1, D. 11.

1607, Novembro, 22, [Lisboa]

AUTO passado pelo desembargador da Casa da Suplicação, Vicente Caldeira de Brito, obre a divida de Diogo Duarte de Elvas à Casa da Índia, por uma fiança de algália que veio da Costa da Mina.

Obs.: m. est.; doc. cosido; algália é um licor aromático segregado nas glândulas do gato da algália.

AHU-São Tomé, cx. 1, doc. 12.

AHU_CU_070, Cx. 1, D. 12.

1610, Março, 17, Lisboa

CONSULTA do Conselho da Fazenda ao rei [D. Filipe II] sobre o requerimento do excontratador das alfândegas do reino, João Baptista Revelasco, solicitando esmola, em virtude de ter sido lesado na execução do contrato da Mina, porque não se cumprira a 
condição relativa às galeotas que deveriam andar naquela costa e a sua fazenda fora tomada com o argumento de não ter dado satisfação do contrato.

Obs.: resolução do vice-rei de Portugal, marquês de Castelo Rodrigo, D. Cristóvão de Moura.

AHU-São Tomé, cx. 1, doc. 15.

AHU_CU_070, Cx. 1, D. 13.

[ant. 1610, Maio, 15]

REQUERIMENTO do mestre da caravela Nossa Senhora da Piedade, António Rodrigues, ao rei [D. Filipe II] solicitando que lhe fosse pago o frete da caravela, em virtude dela ter sido tomada em 1604 para ir à Costa da Mina, deixando ele suplicante de puder sustentar os filhos.

Obs.: doc. numerado e cosido; anexo: decretos, requerimento e recibo.

AHU-São Tomé, cx. 1, doc. 16.

AHU_CU_070, Cx. 1, D. 14.

\section{4, Junho, 27, Lisboa}

CONSULTA do Conselho Ultramarino ao rei D. João IV sobre as cartas do governador de S. Tomé, Cristóvão de Barros Rego, e dos oficiais da câmara da ilha de Santiago de Cabo Verde, questionando se, de acordo com a nova lei, haveriam de marcar as patacas do rosário e o valor por que haviam de circular, bem como o dos tostões velhos.

Obs.: ver AHU_CU_CONSULTAS MISTAS, Cod. 15, fl. 103v-104v; anexo: carta régia (cópia).

AHU-Cabo Verde, cx. 5, doc. 22.

AHU_CU_024, Cx. 4, D. 269.

1661, Março, 24, Lisboa

CONSULTA do Conselho Ultramarino ao rei [D. Afonso VI] tendo em conta a informação do governador de Cabo Verde, Pedro Ferraz Barreto, sobre o requerimento de Pedro de Barros, cidadão e morador da ilha de Santiago, solicitando o cargo de provedor da Fazenda Real; sobre o pedido do ouvidor-geral, Manuel da Costa Palma, nomeado para as ilhas, solicitando o mesmo cargo, como se fizera com o seu antecessor, João Homem de Menezes e com o ouvidor nomeado para a ilha de S. Tomé.

Obs.: resolução da rainha regente D. Luísa de Gusmão.

$\begin{array}{lllllll}\text { AHU-Cabo } & \text { Verde, } & & & & & \text { A, }\end{array}$

AHU_CU_024, Cx. 4, D. 329.

1610, Junho, 7, Lisboa

CONSULTA do Conselho da Índia ao rei [D. Filipe II] sobre a carta dos oficiais da Câmara de São Tomé, em nome do povo, pedindo o contrato da ilha de São Tomé ao preço firmado com o contratador Jorge Rodrigues da Costa, alegando que antes dele entravam ali muitos escravos do Congo e de Angola, pagando os respectivos direitos à Fazenda Real, e que com o contratador os moradores não podiam resgatar e empobreciam; referindo que o requerimento de Fernão Jorge, em nome do povo, asseguraria o lanço do contrato e mencionando a importância comercial de São Tomé e o seu papel para recuperar a ilha do

Príncipe, sendo fácil navegar dali para a ilha de Santa Helena para descobrir mais portos e comércio.

Obs.: publ. no "Boletim" do AHC, Vol. 1, 1950, pág. 226-229.

AHU-São Tomé, cx. 1, doc. 17.

AHU_CU_070, Cx. 1, D. 15. 
1610, Outubro, 6, Lisboa

CONSULTA do Conselho da Fazenda ao rei [D. Filipe II] advertindo que o Conselho da Índia pretendia prover os capitães das caravelas que iam à Costa da Mina, apesar dessa incumbência ser do Conselho da Fazenda porque os capitães levavam a fazenda que ia para a fortaleza de São Jorge para pagamento dos ordenados dos oficiais, devendo prestar contas ao feitor e recebedor da Fazenda.

Obs.: doc. cosido; resolução do vice-rei de Portugal, marquês de Castelo Rodrigo, D. Cristóvão de Moura; anexo: consultas, certidão, informação.

AHU-São Tomé, cx. 1, doc. 18.

AHU_CU_070, Cx. 1, D. 16.

1610, Dezembro, 2, Lisboa

CONSULTA do Conselho da Índia ao rei [D. Filipe II] sobre as cartas do capitão e governador de São Tomé, Constantino Lobo [Tavares], acerca do prejuízo que o contratador Jorge Rodrigues da Costa causava ao não levar fazendas àquela ilha, nem pagar as ordinárias, e por arrendar as viagens aos navios de resgate e receber os direitos nas Índias, ficando a ilha de São Tomé sem qualquer proveito.

Obs. publ. no "Boletim" do AHC, Vol.1, 1950, pág. 229-231.

AHU-São Tomé, cx. 1, doc. 19.

AHU_CU_070, Cx. 1, D. 17.

1753, Janeiro, 24, ?

MAPA feito por José Francisco Rocha, sobre a entrada, gastos e saída da carregação de mercadorias de Pernambuco, consignadas por José de Freitas Sacoto, para a Costa da Mina, Ajudá e Anamabu, apresentando as contas correntes do indivíduo, um mapa dos navios da Bahia, do Rio de Janeiro, de Pernambuco e de Lisboa que podiam transportar escravos, um mapa da moenda de açúcar, outro da despesa de um navio para carregar tabaco, aguardente e praças para a Companhia e outro para um navio que levasse tabaco à Costa da Mina.

Obs.: doc. numerado e incompleto; anexo: mapas.

Verificar se pode ser incluído na caixa 9, talvez nos doc. 1 ou 23.

AHU-São Tomé, cx. 8, doc. 100.

AHU_CU_070, Cx. , D. .

[ca. 1725]

CARTA ao rei [D. João V] sobre o estado das fazendas e rendimento do morgado instituído na ilha de São Tomé por Gaspar de Araújo e Sousa, em 1588, tendo instituído o morgado nas fazendas Camarão, Água Izé e Castelos São Miguel, São Tiago e Belém; dando conta dos rendimentos das que ainda resistiam e da renda que pagavam à Santa Casa da Misericórdia, ao Hospital e à Sé; explicando que as fazendas Água Izé e Castelos do Sul eram conservadas pelos seus escravos e no lugar das casas de pedra os rendeiros tinham construído casas de madeira que davam rendimento; explicando que a de Agua Izé era uma fazenda de açúcar, que possuía um engenho danificado e alguns dos cobres para o fabrico do açúcar, existindo lá muitos escravos e gado vacum.

Obs.: doc. incompl.; datação aferida pela marca de água; possivelmente a carta é do provedor da Fazenda Real da ilha de São Tomé, João de Araújo Lima.

AHU-São Tomé, cx. 5, doc. 31.

AHU_CU_070, Cx. 5, D. 563.

1721, Julho, 10, Lisboa 
CONSULTA (cópia) do Conselho Ultramarino ao rei D. João V sobre as cartas do [vice-rei] do Estado do Brasil, [Vasco Fernandes César de Meneses], e do tesoureirogeral do mesmo Estado, Manuel Cardoso da Silva, acerca do requerimento do capitão de navios de escravos da Costa da Mina, José de Torres, ao Conselho da Fazenda, para levar caixas de açúcar para aquela costa; mencionando que o requerente, Jorge Lampim, Paulo dela Campa e um companheiro deste tinham um acordo com os holandeses para lhes levar açúcar, tabaco, ouro e outros géneros, a São Jorge da Mina, em troca de escravos, panos e ferro livres de direitos, o que prejudicava o comércio e a Fazenda Real.

Obs.: ver AHU_CU_CONSULTAS DA BAHIA, Cod. 253, fl. 239v-242.

AHU-São Tomé, cx. 4, doc. 81.

AHU_CU_070, Cx. 5, D. 507.

1610, Dezembro, 2, Lisboa

CONSULTA do Conselho da Fazenda ao rei [D. Filipe II] sobre os requerimentos dos capitães das caravelas e galeotas que iam à Costa da Mina, [João Figueiroa de Mesquita e João Rodrigues Roxo], solicitando ajudas de custo como as que tinham sido dadas aos anteriores capitães.

Anexo: informação, escritos, conhecimento e consultas.

AHU-São Tomé, cx. 1, doc. 20.

AHU_CU_070, Cx. 1, D. 18.

[post. 1612, Julho, 4, Lisboa]

REQUERIMENTO da abadessa [soror Maria da Anunciação] e religiosas do mosteiro de Santa Marta de Jesus [de Lisboa] ao rei [D. Filipe II] solicitando o pagamento dos mantimentos que haviam recebido por esmola por parte do capitão e cavaleiro do hábito de Cristo, João Álvares Sardinha, que os ganhara na Costa da Mina.

Obs.: m. est.; doc. cosido; anexo: procuração, requerimentos.

AHU-São Tomé, cx. 1, doc. 23.

AHU_CU_070, Cx. 1, D. 19.

[ant. 1612, Agosto, 9]

REQUERIMENTO de António da Guerra, tesoureiro e curador da alma do capitão-mor das galeotas da Costa da Mina, Vasco de Morais, seu cunhado, ao rei [D. Filipe II] solicitando que nas provisões relativas às contas com o tesoureiro da Casa da Mina, se acrescentassem apostilhas de acordo com o novo regimento.

Obs.: m. est.

AHU-São Tomé, cx. 1, doc. 24.

AHU_CU_070, Cx. 1, D. 20.

\section{2, Agosto, 27, Lisboa}

PORTARIA (cópia) do conde almirante, informando da mercê concedida aos cónegos na ilha de São Tomé, sacerdotes Luís Quaresma, Tomé Rodrigues e Crespim do Amaral, para irem servir nas ditas conezias e arcediago, apesar de deverem direitos.

Obs.: m. est.

AHU-São Tomé, cx. 1, doc. 25.

AHU_CU_070, Cx. 1, D. 21.

[ant. 1612, Outubro, 20, Lisboa]

REQUERIMENTO [do secretário] do Conselho de Estado, Pedro Álvares Pereira, ao rei [D. Filipe II] solicitando que o contratador lhe pagasse os dois escravos do contrato de 
São Tomé a que tinha direito, mencionando os casos análogos dos aposentadores da corte, Pero Bugalho e Pantaleão Correia, dos ajudas [criados] de Sua Majestade, Diogo de Vargas e Eugénio Marvão, e do doutor do Conselho da Fazenda, António Dinis.

Obs.: m. est.; doc. cosido; anexo: certidões e parecer (minuta).

AHU-São Tomé, cx. 1, doc. 22.

AHU_CU_070, Cx. 1, D. 22.

1612, Novembro, 17, Lisboa

AUTO (traslado) mandado fazer pelo corregedor da comarca de Viana [do Castelo], Luís Pinheiro Botelho, sobre o aprestamento do navio Nossa Senhora de Monserrate, capitaneado por João Rodrigues Roxo, e as diligências para que saísse de Baiona, onde arribara devido a uma tempestade, vindo da Costa da Mina.

Obs.: m. est.; doc. numerado e cosido; anexo: certidão (traslado), folha de despesas (traslado).

AHU-São Tomé, cx. 1, doc. 26.

AHU_CU_070, Cx. 1, D. 23.

\section{3, Abril, 24, Lisboa}

CONSULTA do Conselho da Fazenda ao rei [D. Filipe II] sobre o requerimento de Pedro da Silva, capitão da nau São Jacinto do contrato de Jorge Rodrigues Solis, nomeado por Sua Majestade capitão e governador da fortaleza de São Jorge da Mina, solicitando que dos direitos das fazendas da nau Santa Helena ou noutras que viessem [a São Tomé], se pagasse o que eles tinham tomado de Diogo Simões Madeira, em Moçambique, e dado ao feitor daquela fortaleza, para conserto e apresto da nau. Obs.: resolução do vice-rei de Portugal, Bispo de Leiria, D. Pedro de Castilho. AHU-São Tomé, cx. 1, doc. 27.

AHU_CU_070, Cx. 1, D. 24.

$58-$

[ca. 1613]

CONTRATO (traslado das condições) para o comércio de escravos na ilha de São Tomé, entre a Coroa e Fernão Jorge, estabelecendo as obrigações do contratador e do feitor com as autoridades da ilha e a Fazenda Real e o fornecimento de mercadorias na ilha, através dos navios de resgate.

Obs.: datação aferida em SERAFIM, Cristina Maria Seuanes - As ilhas de São Tomé no século XVII. Lisboa: Centro de História de Além-Mar da Universidade Nova de Lisboa, 2000. P. 243.

AHU-São Tomé, cx. 1, doc. 14.

AHU_CU_070, Cx. 1, D. 25.

[ca. 1613]

CONSULTA (minuta) do Conselho da Fazenda ao rei [D. Filipe II] sobre o requerimento do governador [de São Jorge] da Mina, D. Duarte Lima, solicitando o provimento da fortaleza em Pero da Silva, para que ele signatário recebesse os seus ordenados e pagasse os soldos dos soldados e oficiais, em virtude de nunca ter recebido o seu ordenado, não haver mantimentos na ilha e ter usado dinheiro do cofre dos órfãos e defuntos como empréstimo para pagar aos soldados.

Obs.: datação aferida pelo ano em que o cargo de governador passou de Duarte Lima para Pero da Silva.

AHU-São Tomé, cx. 59, doc. 2. 
AHU_CU_070, Cx. 1, D. 26.

[ant. 1614, Maio, 9, São Tomé]

REQUERIMENTO de Maria de Sauzedo, viúva de Jerónimo de Moura Gavião, solicitando a propriedade e serventia do ofício de escrivão da feitoria da ilha de São Tomé, que fora de seu marido e de seu sogro, Gaspar de Moura Gavião, para o seu filho Sebastião, alegando ter três filhos menores, muitas dívidas e o seu marido pouco ter gozado a propriedade do ofício; apresentando as informações recolhidas pelo governador Luís Dias Abreu.

Obs.: m. est.; doc. cosido; dois doc. em perg.; anexo: escrito, carta, requerimentos, cartas de nomeação, certidões, instrumento de informação, auto de testemunhas.

AHU-São Tomé, cx. 1, doc. 28.

AHU_CU_070, Cx. 1, D. 27.

1614, Maio, 9, Lisboa

CONSULTA do [Conselho da Índia] ao rei [D. Filipe II] sobre uma carta do governador de São Tomé, Feliciano Coelho de Carvalho, sugerindo que os contratadores deixassem na ilha duas partes dos escravos dos resgates, que se unisse o contrato do Congo ao daquela ilha e que os contratadores arrendassem ali as viagens para a costa de Arda e outros portos, ou usassem pilotos e interpretes dali para que os negros não subissem o preço das

peças.

AHU-São Tomé, cx. 1, doc. 29.

AHU_CU_070, Cx. 1, D. 28.

[ant. 1615, Março, 26]

REQUERIMENTO do [contratador do] contrato de São Tomé, Fernão Jorge, ao rei [D. Filipe II] solicitando provisão para trazer da Índia vários quintais de búzio para usar nos resgates, carregados por Bernardo Montepio e Duarte J[...] Caminha.

Obs.: m. est.; doc. cosido; anexo: certidão.

AHU-São Tomé, cx. 1, doc. 32.

AHU_CU_070, Cx. 1, D. 29.

\section{ARQUIVO NACIONAL TORRE DO TOMBO:}

Datas 1540-08-21 - 1540-08-21

Código de referência: PT/TT/CC/1/68/16

Cota atual: Corpo Cronológico: Parte I, mç. 68, n. ${ }^{\circ} 16$

*ALVARÁ de D. JOÃo III PARA SE LEVAR EM CONTA À MULHER E HERDEIROS DE MANUEL VAZ, ALMOXARIFE QUE FOI DA ILHA DE S. TOMÉ, 844 ARROBAS DE AÇÚCAR.

Datas: 1529-04-13 - 1529-04-13

Código de referência: PT/TT/CC/1/42/90

Cota atual: Corpo Cronológico, Parte I, mç. 42, n. ${ }^{\circ} 90$

* RELATÓRIO DE JOÃ O LOBATO, FEITOR DA ILHA DE S. TOMÉ, PARA D. JOÃO III SOBRE O ESTADO ECONÓMICO E SOCIAL DE S. TOMÉ. Dandolhe conhecimento ter plantado nas fazendas de Praia Preta, canas para 4 arrobas de 
açúcar e porque o mesmo senhor as mandou entregar aos tratadores, determinou fazer apenas 3 engenhos.

Datas: 1530-03-07 - 1530-03-07

Código de referência: PT/TT/CC/1/44/101

Cota atual: Corpo Cronológico, Parte I, mç. 44, n. ${ }^{\circ} 101$

MANDADO DO REI PARA O ALMOXARIFE DOS ESCRAVOS, RECEBEDOR DA VINTENA E FEITOR DAS ILHAS, CARREGAR SOBRE SI EM RECEITA 12.317 ARROBAS DE AÇÚCAR DA ILHA DE S. TOMÉ, AS QUAIS HÁ-DE HAVER DE DUARTE DE LONHA PELOS DIREITOS DA MESMA ILHA.

Datas: 1531-10-24 - 1531-10-24

Código de referência: PT/TT/CC/1/47/78

Cota atual: Corpo Cronológico, Parte I, mç. 47, n. ${ }^{\circ} 78$

ALVARÁ DE D. JOÃO III EM QUE MANDA A MANUEL VAZ, ALMOXARIFE DA ILHA DE S. TOMÉ, QUE NÃO EXECUTE DUARTE DE NORONHA POR 97 ARROBAS E 24 ARRÁTEIS DE AÇÚCAR, QUE É A METADE DE 191 $\begin{array}{lllllllll}\text { ARROBAS } & \mathrm{E} & 16 & \text { ARRÁTEIS QUE } & \text { IMPORTAM } & 1 \% & \text { DO } & \text { DITO }\end{array}$ ARRENDAMENTO.

Datas 1531-11-13 - 1531-11-13

Código de referência: PT/TT/CC/1/47/99

Cota atual: Corpo Cronológico, Parte I, mç. 47, n. ${ }^{\circ} 99$

ALVARÁ DE D. JOÃO III EM QUE MANDA A SEUS CONTADORES QUE LEVEM EM CONTA A MANUEL VAZ, FEITOR QUE FOI DA ILHA DE S. TOMÉ, 250 ARROBAS E 22 ARRÁTEIS DE AÇÚCAR, QUE SE MOSTRA QUEBRAREM NO MAR, DAS 1.855 ARROBAS QUE DA DITA ILHA ENVIOU.

Datas: 1532-05-23 - 1532-05-23

Código de referência: PT/TT/CC/1/49/5

Cota atual: Corpo Cronológico, Parte I, mç. 49, n. ${ }^{\circ} 5$

ALVARÁ DO REI PARA SE LEVAREM EM CONTA A MANUEL VAZ, FEITOR QUE FOI NA ILHA DE S. TOMÉ, 118 ARROBAS DE AÇÚCAR PARA A QUEBRA QUE TEVE NOS ANOS DE SEU CONTRATO.

Datas:

Código de referência:

1536-07-06 - 1536-07-06 $\mathrm{PT} / \mathrm{TT} / \mathrm{CC} / 1 / 57 / 58$

Cota atual: Corpo Cronológico, Parte I, mç. 57, n. $^{\circ} 58$

CERTIDÃO DO FEITOR E OFICIAIS DA CASA DA ÍNDIA A REQUERIMENTO DE GABRIEL FERNANDES EM QUE CERTIFICARAM COMO O NAVIO BOM JESUS VEIO DA ILHA DE S. TOMÉ CARREGADO DE AÇÚCAR E ESCRAVOS.

Datas 1524-11-22 - 1524-11-22

Código de referênciaPT/TT/CC/2/121/104

Cota atual: Corpo Cronológico, Parte II, mç. 121, n. ${ }^{\circ} 104$

CONHECIMENTO EM QUE SE DECLARA QUE O RECEBEDOR DO ALMOXARIFADO DA ILHA DE SÃO TOMÉ, GASPAR DIAS, RECEBEU POR MANDADO DO CONTADOR, 980 ARROBAS DE AÇÚCAR. 
Datas:

$1525-09-06$ - 1525-09-06

Código

de

referência:

$\mathrm{PT} / \mathrm{TT} / \mathrm{CC} / 2 / 128 / 69$

Cota atual: Corpo Cronológico, Parte II, mç. 128, n. ${ }^{\circ} 69$

*CONHECIMENTO EM QUE SE DECLARA QUE O SENHOR DO NAVIO S. VICENTE, GONÇALO ÁlVARES, CUJO NAVIO ESTAVA À CARGA NA ILHA DE S. TOMÉ, RECEBEU DO FEITOR E RECEBEDOR DA FAZENDA DO REI, MANUEL VAZ, 1000 ARROBAS DE AÇÚCAR E 30 PEÇAS DE ESCRAVOS PARA ENTREGAR EM LISBOA AO FEITOR E OFICIAIS DA CASA DA MINA.

Datas: 1525-11-13 - 1525-11-13

Código de referência: PT/TT/CC/2/129/219

Cota atual: Corpo Cronológico, Parte II, mç. 129, n. ${ }^{\circ} 219$

*CONHECIMENTO DE CERTIDÃO ONDE SE ATESTA QUE PERO NETO, RECEBEDOR DA FEITORIA DAS ILHAS E ALMOXARIFADOS DOS

ESCRAVOS E VINTENAS DE GUINÉ E ÍNDIAS, RECEBEU DO

ALMOXARIFE DE S. TOMÉ, MANUEL VAZ, 1.114 ARROBAS E MEIA E DOIS ARRATEIS DE AÇÚCAR DOS DÍZIMOS DA DITA ILHA.

Datas: 1526-07-23 - 1526-07-23

Código de referência: PT/TT/CC/2/134/146

Cota atual: Corpo Cronológico, Parte II, mç. 134, n. ${ }^{\circ} 146$

*CERTIDÃO EM QUE CONSTA QUE GONÇALO LOPES, RECEBEU DO ALMOXARIFE DE S. TOMÉ, POR INTERMÉdIO DE ANTÃO PIRES, PILOTO DA NAU SANTA MARIA DO MONTE SANTO, 162 CAIXAS E 1 CAIXÃO DE AÇÚCAR ONDE VINHAM 1.025 ARROBAS E MEIA AS QUAIS SE MOLHARAM E ARRIBARAM A LAGOS, E SENDO PESADAS SE ACHOU DE AÇÚCAR LIMPO 843 ARROBAS E 7 ARRÁTEIS E MEIO.

Dates 1526-08-01 - 1526-08-01

Complete reference: PT/TT/CC/2/135/7

Physical location: Corpo Cronológico, Parte II, mç. 135, n. 7

*RECIBO DE GONÇALO LOPES EM COMO RECEBEU DE MANUEL VAZ, ALMOXARIFE NA ILHA DE S. TOMÉ, POR PEDRO MONTEIRO, PILOTO DA NAU REIS MAGOS, 189 CAIXAS DE AÇÚCAR.

Dates 1526-12-01 - 1526-12-01

Complete reference: PT/TT/CC/2/137/117

Physical location: Corpo Cronológico, Parte II, mç. 137, nº 117

*CONHECIMENTO POR QUE GONÇALO LOPES RECEBEU DE JOÃO DE BARROS, TESOUREIRO DA CASA DA MINA O AÇÚCAR NELE MENCIONADO, DO ENGENHO DO REI QUE TINHA NA ILHA DE S. TOMÉ.

Datas: 1526-12-01 - 1526-12-01

Código de referência: PT/TT/CC/2/137/119

Cota atual: Corpo Cronológico, Parte II, mç. 137, nº 119

*CONHECIMENTO POR QUE GONÇALO LOPES, RECEBEU DE MANUEL VAZ, ALMOXARIFE DA ILHA DE S. TOMÉ, 255 CAIXAS DE AÇÚCAR. 
Datas: 1527-08-28 - 1527-08-28

Código de referência: PT/TT/CC/2/143/148

Cota atual: Corpo Cronológico, Parte II, mç. 143, n. ${ }^{\circ} 148$

*CONHECIMENTO DE GONÇALO LOPES EM QUE RECEBEU DE MANUEL VAZ ALMOXARIFE DA ILHA DE S. TOMÉ POR OFICIO FROIZ MESTRE DA NAU MARIETA 262 CAIXAS DE AÇUCAR NA DITA ILHA.

Datas: 1527-10-17 - 1527-10-17

Código de referência: PT/TT/CC/2/145/43

Cota atual: Corpo Cronológico, Parte II, mç. 145, n. ${ }^{\circ} 43$

CERTIDÃO DO FEITOR ALMOXARIFE DOS ESCRAVOS DA GUINÉ E INDIAS SOBRE O CONTRATO DO AÇUCAR QUE TOMOU DA ILHA DE S. TOMÉ DUARTE DE NORONHA E OUTROS COMO NESTA SE DECLARA.

Datas: 1532-01-31 - 1532-01-31

Código de referência: PT/TT/CC/2/173/112

Cota atual: Corpo Cronológico, Parte II, mç.173, n. ${ }^{\circ} 112$

CONHECIMENTO POR QUE CONSTA QUE JOÃO ANDRÉ, MESTRE DO NAVIO SALVADOR DE AFONSO DE TORRES, RECEBEU DE GABRIEL FERNANDES, RECEBEDOR DO TRATO DA ILHA DE SÃO TOMÉ, 384 CAIXAS DE AÇÚCAR E 59 QUINTAIS DE PAU VERMELHO. Contém também o conhecimento por que consta que Martim Eanes, mestre da nau Santa Maria da Luz, recebeu de Gabriel Fernandes, recebedor do trato da ilha de São Tomé, 500 caixas de açúcar e 60 quintais de pau vermelho.

Datas: 1509-10-04 - 1509-10-04

Código de referência: PT/TT/CC/2/18/151

Cota atual: Corpo Cronológico, Parte II, mç. 18, n. ${ }^{\circ} 151$

*MANDADO DE JOÃO RODRIGUES DE PARADA, ENCARREGADO DO PAGAMENTO DAS DESPESAS DA ARMADA DE SOCORRO A SAFIM, PARA SALVADOR GRAMAXO, RECEBEDOR DO ALMOXARIFADO DA ALFÂNDEGA DO FUNCHAL, ILHA DA MADEIRA, PAGAR À MULHER DE TOMÉ RODRIGUES, MAREANTE. Inclui o conhecimento de quitação relativo a 17 arrobas e 24 arráteis e meio de açúcar, correspondentes ao frete do navio e soldo da equipagem de 2 meses e 2 dias (11.1.1510).

Datas: 1511-01-13 - 1511-01-13

Código de referência: PT/TT/CC/2/24/181

Cota atual: Corpo Cronológico, Parte II, mç. 24, n. ${ }^{\circ} 181$

*ORDEM DE AFONSO DE ALBUQUERQUE PARA QUE O FEITOR DE GOA DÊ A TOMÉ VASQUE MEIO FARDO DE AÇÚCAR PRETO.

País: Goa.

Datas: 1435 - 1836

Código de referência: PT/TT/CFZ

*Documentação com uma forte incidência temática jurídico-financeira. Contém informações sobre todas as rendas do Estado (direitos do marfim, pau-brasil, ouro, escravos, rendimentos agrícolas, etc.) 
Datas: 1754-01-21 - 1789-07-31

Código de referência: PT/TT/MR/EXP/034/599/15

Cota atual: Ministério do Reino, mç. 599, n. ${ }^{\circ} 15$

*REPRESENTAÇÃO DA MESA DA INSPECÇÃO DA BAÍA (BRASIL) PARA A RAINHA [D. MARIA I]

Trata sobre o resgate de escravos da costa da Mina, na África Ocidental, ramo de comércio (que se achava "em estado de decadência e ruina") da qual dependiam para a conservação e aumento da agricultura do açúcar e do tabaco no Brasil. Foram apresentadas propostas para o retabelecimento do referido comércio. Refere a tomada pelos holandeses dos castelos de São Jorge da Mina e de Santo António de Axim, erigidos pelos portugueses. Aborda o fabrico e o comércio do tabaco na capitania da Baía, bem como a boa aceitação deste produto entre os negros da Costa da Mina. Contém doze anexos que incluem um mapa da costa de África. Este abrange uma área geográfica entre o Cabo Palmas e a ilha de São Tomé, e contém bandeiras pintadas ao longo da costa que indicam os fortes e feitorias dos europeus.

Datas: 1529-05-10 - 1529-05-10

Código de referência: PT/TT/CC/1/42/116

Cota atual: Corpo Cronológico, Parte I, mç. 42, n. ${ }^{\circ} 116$

*CARTA DE DUARTE RODRIGUES PARA D. JOÃO III ABORDANDO ENTRE OUTROS ASSUNTOS AS IRREGULARIDADES DO COMÉRCIO ENTRE S. TOMÉ, ACHÉM E MINA. Dando-lhe conhecimento da jornada que fez indo como capitão da nau em que Damião Dias levava a armada para o Congo. Que entre a ilha de Fernão Pinto e Terra Firme tinha o mesmo senhor uma terra que produzia muita malagueta e dos roubos que se faziam à Fazenda Real na ilha de S. Tomé.

Datas: 1557-01-10 - 1557-01-10

Código de referência: PT/TT/CC/1/100/71

Cota atual: Corpo Cronológico, Parte I, mç. 100, n. ${ }^{\circ} 71$

* CARTA DE FREI FERNANDO DA PAZ DANDO CONTA AO REI HAVER NO MALABAR CINQUENTA IGREJAS, TODAS COM FALTA DE ORNAMENTOS. Pedindo provisão para se entregar a todos os que se fizessem cristãos suas fazendas, escrevendo aos reis gentios, para assim o executarem. Que se devia destornar dos cristãos de $\mathrm{S}$. Tomé os ritos dos arménios e mandar aos governadores da Índia não consentissem entre eles houvessem bispos arménios, mandando-lhes um bispo que desse ordens a seus filhos para assim deixarem os ritos gentílicos.

Datas: 1557-07-13 - 1557-07-13

Código de referência: PT/TT/CC/1/101/65

Cota atual: Corpo Cronológico, Parte I, mç. 101, n. ${ }^{\circ} 65$

CARTA DE DIOGO RODRIGUES DANDO PARTE AO REI FALECER O EMBAIXADOR MANUEL PACHECO E QUE FIZERA TESTAMENTO COM ANTÓNIO FERNANDES, INIMIGO DO REI DO CONGO.

Datas: 1558-06-01 - 1558-06-01

Código de referência: PT/TT/CC/1/102/103

Cota atual: Corpo Cronológico, Parte I, mç. 102, n. ${ }^{\circ} 103$ 
*CARTA DE MEM dE SÁ DANDO PARTE AO REI FICAR A CAPITANIA DOS ILHÉUS LIVRE DOS GENTIOS COM O SOCORRO QUE MANDARA AO CAPITÃO VASCO FERNANDES COUTINHO, A QUEM LHE PARECIA DEVIA O MESMO SENHOR MANDAR RENDER POR ESTAR MUITO VELHO E CONCEDER NOVOS PRIVILÉGIOS AOS HOMENS RICOS DE S. TOMÉ QUE FOSSEM PARA A DITA CAPITANIA. QUE TIVERA NOTICIAS ESTAREM OS FRANCESES NO RIO DE JANEIRO COM MUITA GENTE ARMADA.

Datas:

Código

$1558-10-16-1558-10-16$

Cota atual: Corpo Cronológico, Parte I, mç. 103, n. ${ }^{\circ} 11$ *CARTA DE DIOGO RODRIGUES REPRESENTANDO À RAINHA A ESTIMAÇÃO QUE O REI DO CONGO FIZERA DAS CARTAS DE SUAS ALTEZAS PARA ONDE FORA COM O EMPREGO DE PROVISOR A TRATAR DO NEGÓCIO DA FÉ DAQUELES REINOS E QUE CUIDANDO NAS OBRIGAÇÕES DO DITO OFÍCIO O PRENDERAM METENDO-O ENTRE MALFEITORES.

Datas: $1558-10-22$ - 1558-10-22

Código de referência: PT/TT/CC/1/103/13

Cota atual: Corpo Cronológico, Parte I, mç. 103, n. ${ }^{\circ} 13$

*CARTA DO OUVIDOR ALEIXO LOPES DANDO CONTA AO REI DA DILAÇÃO DOS PROCESSOS DA ILHA DE S. TOMÉ ORIGINADA DAS SUSPENSÕES QUE AS PARTES MOTIVAVAM AFIM DE SE DEMORAREM AS CAUSAS CONTRA A ORDENAÇÃO. Que o capitão Pedro Botelho tirara muita parte daquela ilha da jurisdição do bispo, que a havia usurpado, pelo que movera dúvidas, ameaças com censuras aos provedores que conheciam das capelas da jurisdição secular.

Datas: 1558-10-23 - 1558-10-23

Código de referência: PT/TT/CC/1/103/14

Cota atual: Corpo Cronológico, Parte I, mç. 103, n. ${ }^{\circ} 14$

*CARTA DO CAPITÃo PEDRO BOTELHO AO REI: Expondo ao rei que pelos navios em que foi Jácome Leite dera parte do estado da ilha de $\mathrm{S}$. Tomé e remetera em letra algum dinheiro e participara os serviços que fazia ao dito senhor e que por esperar os navios do rei não fora à ilha do Príncipe tirar a devassa que o mesmo senhor mandara. Que na dita ilha de S. Tomé eram contínuas as suspeições que se davam dos ministros, o que causava irreparável prejuízo ás partes.

Datas: $1558-12-10$ - 1558-12-10

Código de referência: PT/TT/CC/1/103/20

Cota atual: Corpo Cronológico, Parte I, mç. 103, n. ${ }^{\circ} 20$

*CARTA DE FERNÃO RODRIGUES EXPONDO AO REI QUE O BISPO DE S. TOMÉ DETERMINARA QUE AS PESSOAS QUE COMPRASSEM ESCRAVOS NAQUELA FEITORIA DECLARASSEM SEUS NOMES E SE OBRIGASSEM A DOUTRINÁ-LOS PARA SE CONSTITUÍREM NO GRÉMIO DOS CRISTÃOS, DO QUE SE LHE TOMARIA CONTRA NA FORMA DA PROVISÃO REAL. 
Datas: 1558-12-22 - 1558-12-22

Código de referência: PT/TT/CC/1/103/25

Cota atual: Corpo Cronológico, Parte I, mç. 103, n. ${ }^{\circ} 25$

CARTA DO BISPO DE S. TOMÉ RELATANDO VÁRIAS NOTÍCIAS AO REI.

Dando parte ao rei falecer o deão da Sé, que tirara o abuso de levarem os clérigos pela administração dos sacramentos aos enfermos 100 réis a cada um, motivo porque morriam muitos pobres sem sacramentos. Que o dito benefício se devia prover em pessoa letrada de bons costumes e com obrigação de pregar para utilidade no espiritual e temporal dos mesmos enfermos e que a dita ilha precisava de corregedor e juiz de fora para a boa administração da justiça.

Datas: 1559-06-23 - 1559-06-23

GEOGRAPHIC

NAME:

Roma

Código de referência: PT/TT/CC/1/103/86

Cota atual: Corpo Cronológico, Parte I, mç. 103, n. ${ }^{\circ} 86$

*CARTA DO COMENDADOR-MOR D. AFONSO EXPONDO AO REI QUE PELO CORREIO DE CASTELA RESPONDERA ÀS CARTAS QUE LHE LEVARA LOURENÇO PIRES A QUEM INFORMARIA DOS NEGÓCIOS DOS PADRES DA COMPANHIA. QUE PELA MOLÉSTIA DO PAPA NÃO CUIDARA AINDA EM QUE LOURENÇO PIRES LHE BEIJASSE O PÉ E NO ENTANTO SE ACHAVA OCUPADO COM A LISTA DOS NEGÓCIOS QUE ESTAVAM POR CONCLUIR. QUE POR NÃO FALECER O BISPO DE S. TOMÉ NÃO PEDIRA AS SÚPLICAS A SUA SANTIDADE.

Datas: 1561-06-24 - 1561-06-24

GEOGRAPHIC NAME: Viana do Castelo

Código de referência: PT/TT/CC/1/104/138

Cota atual: Corpo Cronológico, Parte I, mç. 104, n. ${ }^{\circ} 138$

*CARTA DE VASCO AFONSO PINTO, ALMOXARIFE DA ALFÂNDEGA DE VIANA DO CASTElo AO REI D. SEBASTIÃO: Carta de Vasco Afonso Pinto, almoxarife da Alfândega de Viana ao rei D. Sebastião, queixando-se de Manuel Lobo, cavaleiro da Casa de Sua Alteza, estar naquela vila tomando as contas aos mercadores da dita alfândega dos anos de 1554 até 1557, em que gastara um mês quando qualquer outra pessoa o faria em 8 dias e agora está com os livros dos rendeiros há 2 meses e outros tantos gastara com o acabar levando mais do que lhe pertence. Pede a Sua Alteza mande a António da Silva, juiz da dita alfândega, com o escrivão diante dele, tome as ditas contas por ser pessoa auta para isso.

Datas: 1560-02-20 - 1560-02-20

Código de referência: PT/TT/CC/1/104/3

Cota atual: Corpo Cronológico, Parte I, mç. 104, n. 3

*CARTA DO BISPO DE S. TOMÉ PARA O REI D. SEBASTIÃo PARTICIPANDO QUE OS JESUÍTAS TINHAM CHEGADO ÀQUELA ILHA E AÍ OS FIZERA ESPERAR PELO EMBAIXADOR DO REI DO CONGO E DE OUTROS ASSUNTOS: O bispo duvida fazerem-se católicos os naturais do reino de Angola, sem que o mesmo senhor lhe desse faculdade para negociarem.

Datas: 1561-09-17 - 1561-09-17

Código de referência: PT/TT/CC/1/105/36

Cota atual: Corpo Cronológico, Parte I, mç. 104, n. ${ }^{\circ} 36$ 
*CARTA DE PEDRO bOTELHO AO SECRETÁRIO PÊRO DE ALCÁÇOVA CARNEIRO EM QUE LHE DIZ RECEBEU A SUA CARTA, NA QUAL LHE ESCREVE SOBRE OS NEGÓCIOS DE SIMÃO LOPES CARDÃO E VÊ OS DESEJOS QUE TINHA DE LHE FAZER MERCÊ.

Datas: 1561-11-04 - 1561-11-04

Código de referência: PT/TT/CC/1/105/58

Cota atual: Corpo Cronológico, Parte I, mç. 104, n. ${ }^{\circ} 58$

*CARTA DE FERNÃO DA ORTA PARA PÊRO DE ALCÁÇOVA CARNEIRO, SECRETÁRIO DE D. SEBASTIÃO, EM QUE LHE DAVA CONTA QUE SE TINHA DILATADO TANTO TEMPO EM ESCREVER, POR QUERER MANDAR LETRAS DA FAZENDA, QUE O REI TINHA MANDADO VENDER.

Datas: 1562-01-31 - 1562-01-31

Código de referência: PT/TT/CC/1/105/97

Cota atual: Corpo Cronológico, Parte I, mç. 104, n. ${ }^{\circ} 97$

*CARTA MISSIVA DA CÂMARA DA CIDADE DE S. TOMÉ EM QUE DÃO CONTA AO REI D. SEBASTIÃO DA NECESSIDADE DE JUSTIÇA POR ESTAREM PADECENDO MIL INJÚRIAS E INSOLÊNCIAS, NO QUE PEDEM TODO O SOCORRO E QUE NÃO POSSAM ENTRAR A SERVIR OFÍCIOS PESSOAS DOMÉSTICAS DO GOVERNO E DOS MINISTROS.

Datas: 1562-09-08 - 1562-09-08

Código de referência: PT/TT/CC/1/106/14

Cota atual: Corpo Cronológico, Parte I, mç. 106, n. ${ }^{\circ} 14$

*CARTA DO CARDEAL DE PISA PEDINDO AO REI D. SEBASTIÃO QUE APROVASSE A DESISTÊNCIA QUE O BISPO DE S. TOMÉ HAVIA FEITO DA COADJUTÓRIA DO MOSTEIRO DE CARVOEIRO EM PEDRO DA GRÃ, QUE SE ACHAVA JÁ CONCEDIDA POR SUA SANTIDADE.

Datas: 1562-11-04 - 1562-11-04

Código de referência: PT/TT/CC/1/106/31

Cota atual: Corpo Cronológico, Parte I, mç. 106, n. ${ }^{\circ} 31$

*CARTA DE CRISTÓVÃO DE ORTA DE SOUSA, GOVERNADOR DA ILHA DE S. TOMÉ, DANDO CONTA À RAINHA D. CATARINA DAS DESORDENS QUE SE MOVERAM POR MORTE DE D. DIOGO, REI DO CONGO: Que o rei de Angola se fizera cristão e tivera na maior estimação o recado da mesma senhora e os padres que lhe enviara.

Datas: 1565 - 1565

Código de referência: PT/TT/CC/1/107/97

Cota atual: Corpo Cronológico, Parte I, mç. 107, n. ${ }^{\circ} 97$

*CARTA DE FREI RODRIGO DAS PIAS EXPONDO À RAINHA RETIRAR-SE DO CONGO PELA MORTE INOCENTE QUE DERAM AO REI DA MESMA CIDADE; QUE CHEGANDO À ILHA DE S. TOMÉ SE RECOLHERA NA CASA DE D. ANA DE CHAVES, DONA NOBRE E VIRTUOSA, A QUAL QUERENDO EDIFICAR UM CONVENTO DE S. FRANCISCO PARA O QUE TINHA BREVE, PEDIA AO REI MANDASSE DOIS RELIGIOSOS PARA SE PRINCIPIAR. 
Datas: 1582-08-12 - 1582-08-12

Código de referência: PT/TT/CC/1/111/98

Cota atual: Corpo Cronológico, Parte I, mç. 111, n. $^{\circ} 98$

*CARTA DE ANTÓNIO MONTEIRO MACIEL PARA D. FILIPE I INFORMANDO TER SIDO AVISADO PELO CAPITÃO DA MINA ESTAREM TRÊS NAUS NA COSTA DE FRANÇA COM GENTE PORTUGUESA DAS QUAIS LHE MANDARAM CARTAZ DE D. ANTÓNIO QUE REMETIA AO REI COM A CÓPIA DA RESPOSTA: Pedindo-lhe o dito capitão um caravelhão com 50 espingardeiros e frecheiros the mandava escravos comprados da Fazenda Real, por não haver gente ao soldo, que não sendo precisos na Mina se ganharia neles para a despesa da jornada.

Datas: 1606-01-14 - 1606-01-14

Código de referência: PT/TT/CC/1/114/135

Cota atual: Corpo Cronológico, Parte I, mç. 114, n. ${ }^{\circ} 135$

*CARTA DE LUIS DA GAMA PARA O SECRETÁRIO DE ESTADO SOBRE AS DEVASSAS DA ENTRADA DOS INGLESES NA ILHA DE S. TOMÉ, SOBRE O QUE DERA INFORMAÇÃO HAVIA MAIS DE UM ANO E OUTRAS MAIS COISAS QUE NA MESMA SE DECLARAM.

Datas: 1602-04-21 - 1602-04-21

Código de referência: PT/TT/CC/1/114/57

Cota atual: Corpo Cronológico, Parte I, mç. 114, n. ${ }^{\circ} 57$

*CERTIDÃO DE D. FREI FRANCISCO DE VILA NOVA, BISPO DE S. TOMÉ, RELATANDO COMO FORA ELEITO ALCAIDE-MOR. Certifica que por morte de Vasco de Carvalho de Sousa, capitão daquela ilha, fora eleito para seu alcaide-mor João Barbosa da Cunha, por quase todos os votos dos cidadãos e gente do regimento da ilha, e solicita ao rei o fizesse capitão por ser dotado de muita caridade e desinteresse.

Datas: 1609-03-10 - 1609-03-10

Código de referência: PT/TT/CC/1/115/93

Cota atual: Corpo Cronológico, Parte I, mç. 115, nº 93

*CARTA RÉGIA PARA D. CRISTÓVÃO DE MOURA, MARQUÊS DE CASTELO RODRIGO E VICE-REI NESTE REINO, FAZER JUSTIÇA A MANUEL TELES BARRETO E AOS HOLANDESES QUE COM ELE FORAM PRESOS NA ILHA DE S. TOMÉ.

Datas: 1630-04-13 - 1630-04-13

Local: Lisboa

Código de referência: PT/TT/CC/1/118/29

Cota atual: Corpo Cronológico, Parte I, mç. 118, nº 29

*CÓPIA DE UMA CARTA DO GOVERNADOR DESTES REINOS A DAR PARTE AO REI QUE FRANCISCO BARRETO DE MENESES NÃO 
ACEITAVA O GOVERNO DE S. TOMÉ, E QUE PARA EXEMPLO LHE PARECIA QUE O MESMO SENHOR O MANDASSE RESIDIR PARA SANTARÉM ATÉ NOVA MERCÊ, HAVENDO-O POR ESCUSO DO REAL SERVIÇO, ENTRE OUTROS.

Datas: 1630-02-22 - 1630-02-22

Código de referência: PT/TT/CC/1/118/8

Cota atual: Corpo Cronológico, Parte I, mç. 118, no 8

*DELIBERAÇÃO DO CONSELHO DO ULTRAMAR SOBRE O GOVERNO DE S. TOMÉ E CABO VERDE.

Datas: 1514-10-05 - 1514-10-05

Código de referência: PT/TT/CC/1/16/28

Cota atual: Corpo Cronológico, Parte I, mç. 16, n. ${ }^{\circ} 28$

*CARTA DO REI DO CONGO PARA D. MANUEL I, TRATANDO DE VÁRIOS ASSUNTOS E PEDINDO A DOAÇÃO DE S. TOMÉ, QUE É DE FERNÃO DE MELO, COMO PAGAMENTO DOS PREJUIZOS QUE LHE CAUSOU, PARA AÍ FUNDAR UM COLÉGIO PARA EDUCAÇÃO DE RAPAZES E RAPARIGAS DO CONGO. Referiu a vitória que tinha alcançado sobre os seus inimigos, sendo a principal causa o facto de ele e seu primo se terem convertido ao catolicismo.

Datas: 1515-10-04 - 1515-10-04

Código de referência: PT/TT/CC/1/18/116

Cota atual: Corpo Cronológico, Parte I, mç. 18, n..$^{\circ} 116$

ALVARÁ DE D. MANUEL I PARA O ALMOXARIFE DOS ESCRAVOS DAR A BARTOLOMEU DIAS, PILOTO DO NAVIO SANTA CATARINA, 78.000 RÉIS DO CARRETO DE 78 ESCRAVOS QUE VIERAM PARA O DITO SENHOR DA ILHA DE S. TOMÉ.

Datas: 1516-02-29 - 1516-02-29

Localidade: Almeirim (cidade portuguesa pertencente ao Distrito de Santarém)

Código de referência: PT/TT/CC/1/19/131

Cota atual: Corpo Cronológico, Parte I, mç. 19, n. ${ }^{\circ} 131$

*ALVARÁ DE D. MANUEL I PARA O ALMOXARIFE DE S. TOMÉ SOBRE O QUE O VIGÁRIO DA ILHA DE S. TOMÉ DEVERIA RECEBER ANUALMENTE.

Datas: 1499-07-27

Código de referência: PT/TT/CC/1/2/127

Cota atual: Corpo Cronológico, Parte I, mç. 2, n. ${ }^{\circ} 127$

*CARTA DOS MORADORES E VIZINHOS DEGRADADOS DA ILHA DE S. TOMÉ PEDINDO A D. MANUEL I CONFIRME O GOVERNO E CAPITANIA A PÊRO ÁlVARES de CAMINHA POR ESTAREM MUITO SATISFEITOS COM ELE.

Datas: 1499-07-30 -

Código de referência: PT/TT/CC/1/2/128

Cota atual: Corpo Cronológico, Parte I, mç. 2, n. ${ }^{\circ} 128$ 
* CARTA DE PEDRO ÁlVARES DE CAMINHA A D. MANUEL I DIZENDO QUE SEU TIO ÁLVARO DE CAMINHA LHE DEIXOU EM TESTAMENTO A CAPITANIA DA ILHA DE SÃO TOMÉ

Datas: 1499-07-30

Código de referência: PT/TT/CC/1/2/129

Cota atual; Corpo Cronológico, Parte I, mç. 2, n. ${ }^{\circ} 129$

*CARTA DE PÊRO ÁLVARES DE CAMINHA PARA D. MANUEL I PERDOAR A JOÃO MENDES, QUE SE TORNARA GRANDE FAZENDEIRO EM SÃO TOMÉ, O TEMPO QUE LHE FALTAVA PARA CUMPRIR O SEU DEGREDO

Datas: 1499-07-30 - 1499-07-30

Código de referência: PT/TT/CC/1/2/130

Cota atual: Corpo Cronológico, Parte I, mç. 2, n. ${ }^{\circ} 130$

*CARTA DE PEDRO ÁLVARES DE CAMINHA A D. MANUEL I DANDO-LHE CONTA DA SITUAÇÃO DO GOVERNO DA ILHA DE SÃO TOMÉ APÓS O FALECIMENTO DO CAPITÃO ÁLVARO DE CAMINHA

Datas: 1516-11-19 - 1516-11-19

Localidade: Ilha de Santo António.

Código de referência: PT/TT/CC/1/20/127

Cota atual: Corpo Cronológico, Parte I, mç. 20, n. ${ }^{\circ} 127$

* INQUIRIÇÃ̃O SOBRE A NAU DOS ARMADORES QUE DA ILHA DE S. TOMÉ FORAM A BENIM, AO RESGATE, SEM ESPECIAL ORDEM DO SECRETÁRIO DE ESTADO, ANTÓNIO CARNEIRO.

Datas: 1516-12-19 - 1516-12-19

Código de referência: PT/TT/CC/1/20/137

Cota atual: Leis, mç. 2, n. ${ }^{\circ} 38$

* INQUIRIÇÃO SOBRE OS ARMADORES DE S. TOMÉ.

Datas: 1517-03-15 - 1517-03-15

Código de referência: PT/TT/CC/1/21/59

Cota atual: Corpo Cronológico, Parte I, mç. 21, n. ${ }^{\circ} 59$

* CARTA DE BERNARDO SEGURA, CORREGEDOR DA ILHA DA S. TOMÉ, PARA AO REI, TRATANDO ENTRE OUTROS ASSUNTOS, DA BULA DA CRUZADA EM S. TOMÉ E SOBRE A DEFICIENTE ADMINISTRAÇÃO DA ILHA POR FALTA DE CONTROLO DAS CONTAS DAS RENDAS E DIREITOS DOS ALMOXARIFADOS.

Datas: 1517-08-27 - 1517-08-27

Código de referência: PT/TT/CC/1/22/72

Cota atual: Corpo Cronológico, Parte I, mç. 22, n. ${ }^{\circ} 72$

*CARTA DE ANTÓNIO PIRES AO SECRETÁRIO DE ESTADO, ANTÓNIO CARNEIRO, COM A NOTÍCIA DA CHEGADA À SUA ILHA FREI DIOGO BELO, VIGÁRIO NA ILHA DE SÃO TOMÉ, COM A BULA DA CRUZADA. 
Datas: 1520-05-09 - 1520-05-09

Código de referência: PT/TT/CC/1/26/14

Cota atual: Corpo Cronológico, Parte I, mç. 26, n. ${ }^{\circ} 14$

CARTA DE JOÃO MELO, CAPITÃO DA ILHA DE S. TOMÉ PARA O REI NA QUAL O INFORMOU QUE TINHA MANDADO PRENDER E SEQUESTAR ÁLVARO FRADE, POR TRAZER DAS MINAS 10 OU 20 MARCOS DE OURO, PELA DENÚNCIA QUE DEU ANTÓNIO DIAS, QUEM TAMBÉM FORA PRESO.

Datas: 1520-05-09 - 1520-05-09

Código de referência: PT/TT/CC/1/26/15

Cota atual: Corpo Cronológico, Parte I, mç. 26, n. ${ }^{\circ} 15$

*CARTA DE ÁLVARO FRADE PARA O REI NA QUAL LHE DISSE QUE ANTÓNIO DIAS O TINHA DENÚCIADO, POR 10 OU 20 MARCOS DE OURO E QUE ISSO ERA ABSOLUTAMENTE FALSO

Datas 1525-11-30 - 1525-11-30

Localidade: Almeirim

Código de referência: PT/TT/CC/1/33/28

Cota atual: Corpo Cronológico, Parte I, mç. 33, n. ${ }^{\circ} 28$

*ALVARÁ PARA O FEITOR DA ILHA DE S. TOMÉ TIRAR A FRANCISCO DO PRADO O OFÍCIO DE ESCRIVÃO DA DITA FEITORIA, DANDO-LHE 50 CRUZADOS, PREÇO POR QUE COMPROU O DITO OFÍCIO.

Datas: 1525-12-27 - 1525-12-27

Localidade: Congo

Código de referência: PT/TT/CC/1/33/44

Cota atual: Corpo Cronológico, Parte I, mç. 33, n. ${ }^{\circ} 44$

ALVARÁ DO REI DO CONGO POR QUE MANDOU AO CORREGEDOR E MAIS JUSTIÇAS DA ILHA DE S. TOMÉ REMETESSEM PARA PORTUGAL OS NOVE PRISIONEIROS FRANCESES QUE FORAM TOMADOS NUMA NAU.

Datas: 1527-12-16 - 1527-12-16

Localidade: Cochim

Código de referência: PT/TT/CC/1/38/51

Cota atual: Corpo Cronológico, Parte I, mç. 38, n. ${ }^{\circ} 51$

*CARTA DE SEBASTIÃO PIRES DANDO PARTE AO REI D. JOÃO III QUE NA ÍNDIA SE NÃO FAZIA JUSTIÇA NEM SEU SERVIÇO COMO ERA DEVIDO, QUE OS MOUROS CONTINUAVAM A DAR REBATES E QUE TINHAM TOMADO UMA CARAVELA E QUEIMADO 13 NAUS EM QUE MATARAM BASTANTE GENTE DE QUE SE TINHAM FEITO AUTOS, PEDINDO-LHE FINALMENTE UM RETÁBULO PARA A CASA DE S. TOMÉ.

Datas: 1528-01-16 - 1528-01-16

Localidade: Cochim

Código de referência: PT/TT/CC/1/38/90

Cota atual: Corpo Cronológico, Parte I, mç. 38, n. ${ }^{\circ} 90$ 
* CARTa do Padre álvaro Penteado PaRa O Rei D. JOÃo III DIZENDO QUE O GOVERNADOR DA ÍNDIA O DESPACHARA PARA S. TOMÉ, LHE DERA SEU REGIMENTO E QUE O VIGÁRIO-GERAL LHE NÃO TINHA DADO PROVISÃO PARA LHE OBEDECEREM NO ESPIRITUAL PORQUE ELE E OS MAIS CLÉRIGOS ERAM HOMENS DE NEGÓCIO.

Datas: $1530-03-28$ - 1530-03-28

Código de referência: PT/TT/CC/1/44/118

Cota atual: Corpo Cronológico, Parte I, mç. 44, n. ${ }^{\circ} 118$

* CARTA DE FRANCISCO PAIS DO AMARAL, CORREGEDOR DA ILHA DE S. TOMÉ, REMETENDO A D. JOÃO III UNS AUTOS DE JOÃO LOBEIRO E COM ELES A INFORMAÇÃO SOBRE O TRATO DA MINA, COM A NOTÍCIA DOS GRANDES SERVIÇOS QUE NELA SE FAZIAM NO AVIAMENTO E DESPACHO DOS NAVIOS.

Datas:1530-06-03 - 1530-06-03

Código de referência: PT/TT/CC/1/45/31

Cota atual: Corpo Cronológico, Parte I, mç. 45, n. $^{\circ} 31$

* CARTA DE FERNANDO DE CARVALHO DANDO CONTA AO REI QUE NO RIO DA GAIA SE DEIXARAM FICAR MUITOS HOMENS, ASSIM BRANCOS COMO NEGROS, POR HAVER LÁ MUITO OURO, E PEDINDO QUE O MESMO SENHOR LHE DESSE, SOBRE ESTE ASSUNTO, A PROVIDÊNCIA QUE LHE PARECESSE JUSTA.

Datas: 1531-07-05 - 1531-07-05

Código de referência: PT/TT/CC/1/46/116

Cota atual: Corpo Cronológico, Parte I, mç. 46, n. ${ }^{\circ} 116$

* MANDADO PARA QUE NOS CONTOS SE LEVAR EM CONTA AO ALMOXARIFE DE PONTE DE LIMA 20 MIL RÉIS QUE O RECEBEDOR DA VILA DE MONÇÃO PAGOU DE ORDENADO AO JUIZ DE FORA DA VILA, O BACHAREL HENRIQUE PEREIRA, AO QUAL O DITO SENHOR MANDA POR CORREGEDOR DA ILHA DE S. TOMÉ.

Datas: 1532-11-02 - 1532-11-02

Código de referência: PT/TT/CC/1/50/27

Cota atual: Corpo Cronológico, Parte I, mç. 50, n. ${ }^{\circ} 27$

* ALVARÁ PARA O FEITOR E OFICIAIS DA ILHA DE S. TOMÉ PAGAR A MANUEL FERNANDES, PILOTO DO NAVIO SANTA MARIA DA BOA ESPERANÇA, SEIS ESCRAVOS QUE LHE SÃO DEVIDOS DE SEUS ORDENADOS.

Datas: 1532-11-29 - 1532-11-29

Código de referência: PT/TT/CC/1/50/46

Cota atual: Corpo Cronológico, Parte I, mç. 50, n. ${ }^{\circ} 46$

*PROCURAÇÃO DE PEDRO FERNANDES VALHELHAS A DIOGO FERNANDES, ASSISTENTES NA ILHA DE S. TOMÉ, PARA QUE SÓ POSSA EM SEU NOME COBRAR TODO O SOLDO QUE SE LHE DEVER NA FEITORIA DA MESMA ILHA. 
Datas: 1535-10-02 - 1535-10-02

Código de referência: PT/TT/CC/1/56/48

Cota atual: Corpo Cronológico, Parte I, mç. 56, n. ${ }^{\circ} 48$

* CARTA DOS JUÍZES ORDINÁRIOS DA ILHA DE S. TOMÉ AOS OFICIAIS RÉGIOS DA ILHA SOBRE A FUGA DE ESCRAVOS. Mostram receberem da Fazenda Real 40.000 réis para a guerra que faziam ao mocambo, que andava no mato fazendo muitos roubos.

Datas: 1536-10-05 - 1536-10-05

Código de referência: PT/TT/CC/1/57/113

Cota atual: Corpo Cronológico, Parte I, mç. 57, n. ${ }^{\circ} 113$

* CONHECIMENTO DE GASPAR FERNANDES, CHANTRE DA CIDADE DE S. TOMÉ, POR QUE CONSTA RECEBER DO ALMOXARIFE DA MESMA CIDADE 62 MIL RÉIS, IMPORTÂNCIA DO SEU QUARTEL.

Datas: 1536-12-28 - 1536-12-28

Código de referência: PT/TT/CC/1/58/23

Cota atual: Corpo Cronológico, Parte I, mç. 58, n. 23

* CARTA DE FREI LOURENÇO DE GÓIS, GUARDIÃO DO CONVENTO DE SANTO ANTÓNIO DE COCHIM, DANDO PARTE AO REI DO ESTADO DO CRISTIANISMO NAQUELA TERRA, QUE EM GRANGANOR SE FIZERA SUA FORTALEZA EM QUE EDIFICAREM A IGREJA DE S. TOMÉ E TODO O POVO DESEJAVA QUE O MESMO SENHOR LHE DESSE POR SEU CAPITÃO TOMÉ MARTINS, HOMEM DE RARO MERECIMENTO E CRÉDITO ENTRE ELES.

Datas: 1537-09-01 - 1537-09-01

Código de referência: PT/TT/CC/1/59/58

Cota atual: Corpo Cronológico, Parte I, mç. 59, n. ${ }^{\circ} 58$

*CARTA DOS MORADORES DA POVOAÇÃ̃ DE SÃO TOMÉ QUEIXANDOSE A D. JOÃO III DOS AGRAVOS E INSOLÊNCIAS COM QUE ERAM TRATADOS E DO MAL QUE OS GOVERNADORES CUMPRIAM A SUA OBRIGAÇÃO.

Datas: 1537-11-15 - 1537-11-15

Código de referência: PT/TT/CC/1/60/12

Cota atual: Corpo Cronológico, Parte I, mç. 60, n. ${ }^{\circ} 12$

*MANDADO PARA OS CONTADORES DA FAZENDA REAL LEVAREM EM CONTA A GABRIEL FERNANDES, FEITOR DA FEITORIA DA ILHA DE SÃO TOMÉ, 12.840 RÉIS QUE POR ENCERRAMENTO DA SUA CONTA FICOU DEVENDO DO QUE LHE FAZ SUA ALTEZA QUITA E MERCÊ.

Datas: 1538-06-14 - 1538-06-14

Código de referência: PT/TT/CC/1/61/129

Cota atual: Leis, mç. 3 , n. $^{\circ} 21$

*REQUERIMENTO DO REI D. JOÃO III PARA O GOVERNADOR DA ILHA DE S. TOMÉ.

Datas: 1539-12-02 - 1539-12-02

Código de referência: PT/TT/CC/1/66/42 
Cota atual: Corpo Cronológico, Parte I, mç. 66, n. ${ }^{\circ} 42$

*MANDADO PARA O FEITOR E OFICIAIS DA CASA DA ÍNDIA QUE DO DINHEIRO QUE NA DITA CASA FOR DEVIDO A VICENTE GIL DE FRETE DA NAU SANTA CRUZ, SE PAGUE A FERNANDO RODRIGUES DE PALMA 900 MIL RÉIS POR LHOS DEVER O DITO VICENTE GIL DO TRATO DA ILHA DE S. TOMÉ.

Datas:

Código

Copo Cronologico, rerên: *ALVARÁ COM SALVA PARA OS CONTADORES LEVAREM EM CONTA AOS HERDEIROS DE MANUEL VAZ, FEITOR QUE FOI NA ILHA S. TOMÉ, NA CONTA QUE POR ESTE DÃO 104.024 RÉIS QUE ESTE PAGOU A PEDRO GOMES, PILOTO, POR ALVARÁ DE SUA MAJESTADE.

Datas:

1541-03-01 - 1541-03-01

Código de referência: PT/TT/CC/1/69/58

Cota atual: Corpo Cronológico, Parte I, mç. 69, n. ${ }^{\circ} 58$

*CARTA DA CÂMARA DA ILHA DE S. TOMÉ AGRADECENDO AO REI A MERCÊ QUE LHE FEZ DE MANDAR POR SEU CAPITÃO-MOR, FRANCISCO DE BARROS DE PAIVA, PORQUE SÓ COM O SEU NOME OS LEVANTADOS ESTAVAM TÍMIDOS E OS LUGARES MAIS PERIGOSOS SE IAM POVOANDO.

Datas: 1508-12-05 - 1508-12-05

Código de referência: PT/TT/CC/1/7/67

Cota atual: Corpo Cronológico, Parte I, mç. 7, n. $^{\circ} 67$

*CARTA DE GONÇALO LOPES PARA ANTÓNIO CARNEIRO, INFORMANDO ESTAREM APARELHADAS E PRONTAS AS NAUS SÃO VICENTE E SANTO ESPÍRITO PARA A ILHA DO PRÍNCIPE, COM ORDENS PARA QUE O GOVERNADOR DE S. TOMÉ AS PROVESSE DE CARGA.

Datas: 1543-07-11 - 1543-07-11

Código de referência: PT/TT/CC/1/73/117

Cota atual: Corpo Cronológico, Parte I, mç. 73 , n. ${ }^{\circ} 117$

*CARTA DO BISPO DE S. TOMÉ DANDO PARTE A D. JOÃO III DA SOLENIDADE E SUFICIÊNCIA COM QUE EM COIMBRA SE FIZERAM OS ACTOS DOS CANONISTAS E DOS ESTUDANTES, QUE SAIRAM PROVIDOS NOS LUGARES.

Datas: 1543-07-12 - 1543-07-12

Código de referência: PT/TT/CC/1/73/118

Cota atual: Corpo Cronológico, Parte I, mç. 73 , n. ${ }^{\circ} 118$

*CARTA DE DIOGO SOARES, TESOUREIRO DOS DEFUNTOS DA GUINÉ, DANDO PARTE A D. JOÃO III QUE NA ILHA DE S. TOMÉ ESTAVA MUITO DINHEIRO E FAZENDA SONEGADA QUE PERTENCIA AOS MESMOS.

Datas: 1543-04-27 - 1543-04-27

Localidade: Lisboa

Código de referência: PT/TT/CC/1/73/79 
Cota atual: Corpo Cronológico, Parte I, mç. 73 , n. ${ }^{\circ} 79$

*CARTA DO IRMÃO DO REI DO CONGO PEDINDO LICENÇA AO REI D. JOÃO III PARA SE RETIRAR À ILHA DE S. TOMÉ, ONDE TINHA SUA MULHER E CASA, E QUE D. JOÃO MANUEL, SEU FILHO, FICARIA NA CORTE ESPERANDO A RESPOSTA DAS CARTAS DO REI DO CONGO.

Datas: 1546-05-26 - 1546-05-26

Localidade: Ilha de Santiago, Cabo - Verde.

Código de referência: PT/TT/CC/1/78/17

Cota atual: Corpo Cronológico, Parte I, mç. 78, n. ${ }^{\circ} 17$

*CARTA DOS MORADORES E VIZINHOS DA ILHA DE SANTIAGO DE CABO VERDE PEDINDO AO REI QUE FIZESSE A GRAÇA DE ADMITIR NOS OFICIOS DO CONCELHO HOMENS NEGROS E BAÇOS NA FORMA QUE ERA CONCEDIDO AOS DA ILHA DE S. TOMÉ.

Datas: 1547-07-29 - 1547-07-29

Localidade: Roma.

Código de referência: PT/TT/CC/1/79/59

Cota atual: Corpo Cronológico, Parte I, mç. 79, n. ${ }^{\circ} 59$

*CARTA DE GASPAR PINTO DANDO PARTE AO REI PERDEREM-SE A NAU SANTO ESPÍRITO, QUE VINHA DA ÍNDIA CARREGADA DE ESPECIARIAS PARA O REINO, 20 LÉGUAS AO MAR DO NORTE DE MOÇAMBIQUE E A NAU S. TOMÉ QUE IA DO REINO PARA AQUELE ESTADO, 30 LÉGUAS AO SUL DO DITO MAR.

Datas: 1548-11-12 - 1548-11-12

Localidade: Congo

Código de referência: PT/TT/CC/1/80/105

Cota atual: Corpo Cronológico, Parte I, mç. 80, n. ${ }^{\circ} 105$

*CÓPIA DA INQUIRIÇÃ̃O ORDENADA PELO REI TIRADA NA CIDADE DE CONGO SOBRE OS NAVIOS QUE O FEITOR E OFICIAIS DA ILHA DE S. TOMÉ ENVIAVAM PARA ANGOLA E PORTOS DO DITO REINO, SEM ORDEM REAL.

Datas: 1548-11-06 - 1548-11-06

Código de referência: PT/TT/CC/1/81/77

Cota atual: Corpo Cronológico, Parte I, mç. 81, n. ${ }^{\circ} 77$

*CARTA dA CÂMARA DE S. TOMÉ DANDO CONTA AO REI DA PRISÃo QUE SE FIZERA A DAMIÃO LOPES E A JOÃO GONÇALVES QUE, COMO RÉGULOS, SE QUISERAM LEVANTAR COM A ILHA ONDE FIZERAM MUITOS ROUBOS E INSOLÊNCIAS, PEDINDO AO MESMO SENHOR OS MANDASSE SENTENCIAR E CASTIGAR COMO MERECIAM.

Datas: 1549-01-01 -

Localidade: Cranganor

Código de referência: PT/TT/CC/1/82/1

Cota atual: Corpo Cronológico, Parte I, mç. 82, n. $^{\circ} 1$

*CARTA DE FREI VICENTE DANDO CONTA AO REI DO COLÉGIO QUE EDIFICOU EM CRANGANOR E ESTATUTO DOS COLEGIAIS. QUE NUMAS 
SERRAS, DISTANTES DALI 50 LÉGUAS, SE ACHAVAM 40000 OU 50000 HABITANTES QUE TRAZIAM SOBRE O PEITO CRUZES DE PAU, TINHAM REI SOBRE SI E POR BANDEIRA UMA CRUZ, PEDINDO AO REI LHE ALCANÇASSE UMA INDULGÊNCIA PLENÁRIA PARA OS DIAS DE SANTIAGO E SÃO TOMÉ E OUTROS DIAS PRIVILEGIADOS

Datas: 1549-01-25 - 1549-01-25

Código de referência: PT/TT/CC/1/82/34

Cota atual: Corpo Cronológico, Parte I, mç. 82, n. $^{\circ} 34$

*CARTA DE CRISTOVÃO RIBEIRO PARA FRANCISCO DE BARROS DE PAIVA, FIDALGO DA CASA DO REI E CAPITÃO NA CIDADE DE S. TOMÉ, EM QUE LHE DESCONTA DA IDA DO PADRE DIOGO GOMES, SEM A QUAL FICAVAM MEIOS ORFÃOS E QUE A PALAVRA DE DEUS NÃO ERA OUVIDA.

Datas: 1549-02-11 - 1549-02-11

Código de referência: PT/TT/CC/1/82/48

Cota atual: Corpo Cronológico, Parte I, mç. 82, n. ${ }^{\circ} 48$

*CARTA DE JORGE VAZ PARA O CAPITÃO DA ILHA DE S. TOMÉ EM QUE LHE DEU CONTA, QUE DEPOIS DA PARTIDA DO PADRE DIOGO GOMES LHE VIERAM NOTÍCIAS, QUE O REI NÃO QUERIA OUVIR PREGAÇÃO E QUE DEFENDERA SE NÃO ENSINASSE DOUTRINA NO AMBIRO A QUAL ÍA ENSINAR UM DOS PADRES ÁS MULHERES, POR NÃO QUEREREM VIR Á IGREJA E QUE SE NÃO DISSESSE UMA MISSA QUE EM CADA DIA SE COSTUMAVA REZAR E OUTRAS COISAS A ESTE RESPEITO, A QUE O NOSSO REI DEVIA ACUDIR COM TODO O VIGOR.

Datas: 1549-02-18 - 1549-02-18

Código de referência: PT/TT/CC/1/82/56

Cota atual: Corpo Cronológico, Parte I, mç. 82, n. ${ }^{\circ} 56$

*CARTA DE FRANCISCO DE BARROS DE PAIXÃO, GOVERNADOR DA ILHA DE S. TOMÉ, DANDO CONTA AO REI DAS INSOLÊNCIAS QUE PRATICAVA D. DIOGO, REI DO CONGO, ASSIM COM OS PORTUGUESES SECULARES COMO ECLESIÁSTICOS, DESONRANDO AQUELES E FAZENDO DESCER DO PÚLPITO ESTES, LANÇANDO-OS FORA DA IGREJA.

Datas: 1551-12-31 - 1551-12-31

Código de referência: PT/TT/CC/1/87/45

Cota atual: Corpo Cronológico, Parte I, mç. 87, n. ${ }^{\circ} 45$

*CARTA DE FREI DIOGO DE BERMUDES EXPONDO A D. BERNARDO, BISPO DE S. TOMÉ, O DEPLORÁVEL ESTADO EM QUE SE ACHAVA A ÍNDIA, TANTO NO ESPIRITUAL COMO TEMPORAL, PELA POUCO VIGILÂNCIA DO BISPO E CUIDADO DO VICE-REI, PEDINDO-LHE QUE DE TUDO DESSE PARTE AO REI, PARA LHE DAR PROVIDÊNCIA QUE FOSSE DO SEU REAL AGRADO.

Datas: 1553-02-04 - 1553-02-04

Localidade: Lisboa

Código de referência: PT/TT/CC/1/89/65 
Cota atual: Corpo Cronológico, Parte I, mç. 89, n. ${ }^{\circ} 65$

*ALVARÁ RÉGIO PARA FRANCISCO DE MORAIS COMPRAR OBJECTOS DE CULTO, PARA SEREM ENTREGUES AO DEÃO DA SÉ DE S. TOMÉ, DE QUE O REI D. JOÃO III LHE FEZ ESMOLA.

Datas: 1553-08-08 - 1553-08-08

Código de referência: PT/TT/CC/1/90/126

Cota atual: Corpo Cronológico, Parte I, mç. 90, n. ${ }^{\circ} 126$

*CARTA DE JÁCOME LEITE ONDE DESCREVE A VIAGEM PARA S. TOMÉ E AS CONDIÇÕES DA ILHA. Carta de Jácome Leite dando parte ao rei chegar à ilha de S. Tomé, onde achara os negros levantados, para o que assentara em Câmara o modo de se lhe fazer a guerra, assim como a maneira que se devia ter na factura da povoação da banda do sul conforme as reais ordens, pedindo que o mesmo senhor lhe mandasse um prelado para o aumento da fé e reformação daquela cristandade.

Datas: 1554-01-31 - 1554-01-31

Código de referência: PT/TT/CC/1/91/103

Cota atual: Corpo Cronológico, Parte I, mç. 91, n. ${ }^{\circ} 103$

*CARTA DE JÁCOME LEITE RELATANDO AO REI O LEVANTAMENTO QUE HOUVE NA ILHA DE S. TOMÉ, POR CAUSA DA ELEIÇÃO DOS OFICIAIS DE CÂMARA.

Datas: 1554-01-31 - 1554-01-31

Código de referência: PT/TT/CC/1/91/104

Cota atual: Corpo Cronológico, Parte I, mç. 91, n. ${ }^{\circ} 104$

*CARTA dE JÁCOME LEITE AO REI D. JOÃO III EM QUE LHE DÁ CONTA COMO NA TERRA SE LEVANTARAM ALGUNS HOMENS E DISSERAM QUE HAVIAM DE SER CONTRA A JUSTIÇA REAL. Informa que soltou a Jerónimo Rodrigues, sobre fiança de 2.000 cruzados, por não serem castigados os mais levantados e por se não originar alguma coisa na terra que prejudicasse mais o soltou e sobre o que fez o dito Jerónimo Rodrigues, quando se elegeram os juízes para servirem, pede ao rei sejam castigados, conforme as suas culpas o mereçam.

Datas: 1554-01-06 - 1554-01-06

Código de referência: PT/TT/CC/1/91/79

Cota atual: Corpo Cronológico, Parte I, mç. 91, n. ${ }^{\circ} 79$

*CARTA DE ANTÓNIO MARQUES DE OLIVEIRA DANDO PARTE AO REI DO LEVANTAMENTO QUE HOUVE EM S. TOMÉ PELA FACTURA DA GENTE DO GOVERNO E DE COMO SE PORTARA O CAPITÃO JÁCOME LEITE.

Datas: 1554-01-26 - 1554-01-26

Código de referência: PT/TT/CC/1/91/97

Cota atual: Corpo Cronológico, Parte I, mç. 91, n. ${ }^{\circ} 97$

*CARTA DA CÂMARA DE S. TOMÉ DANDO PARTE AO REI DO LEVANTAMENTO QUE JOÃO RODRIGUES GATO, HOMEM CEGO, LUÍS DE ROMA E JORGE DA COSTA FIZERAM NAQUELA ILHA. Acrescenta ainda a carta que estes homens foram cabeças de motim para se fazer novas eleições de oficiais da Câmara, tendo sido presos no castelo, pede ao mesmo senhor que os castigasse exemplarmente. 
Datas 1522-06-17 - 1522-06-17

Código de referência: PT/TT/CC/2/101/139

Cota : Cronológico, Parte II, mç.101, $\mathrm{n}^{\circ} 139$

*RECIBO DE JOÃO GREGO, COMITRE DO BERGANTIM S. TOMÉ DE CRASTO, DE QUE ERA CAPITÃO VICENTE CORREIA, PASSADO A JORGE PEREIRA, FEITOR DA ARMADA DE D. LUIS DE MENESES, UMA DÚZIA DE PEIXES SECOS, PARA MANTIMENTO DO DITO BERGANTIM.

Datas: 1524-08-10 - 1524-08-10

Código de referência: PT/TT/CC/2/117/188

Cota atual: Corpo Cronológico, Parte II, mç. 117, n. ${ }^{\circ} 188$

CONHECIMENTO EM QUE SE DECLARA QUE BALTASAR DE CASTILHO ALCOFORADO RECEBEU DO FEITOR DE CHOROMANDEL (COROMANDEL), RUI MARTINS, 8 BANDEIRAS PARA O NAVIO SÃO TOMÉ DE QUE ERA CAPITÃO.

Datas: 1524-08-10 - 1524-08-10

Código de referência: PT/TT/CC/2/117/189

Cota atual: Corpo Cronológico, Parte II, mç. 117, n. ${ }^{\circ} 189$

*CONHECIMENTO EM QUE SE DECLARA QUE BALTASAR DE CASTILHO ALCOFORADO RECEBEU DO FEITOR DE CHOROMANDEL (COROMANDEL), RUI MARTINS, 8 BANDEIRAS PARA O NAVIO SÃO TOMÉ DE QUE ERA CAPITÃO.

Datas 1524-11-01 - 1524-11-01

Código de referência: PT/TT/CC/2/120/150

Cota atual: Corpo Cronológico, Parte II, mç. 120, n. ${ }^{\circ} 150$

*MANDADO PARA O ALMOXARIFE DE ORMUZ DAR AO COMITRE DO BERGANTIM S. TOMÉ, PARA MANTIMENTO DE 2 CANARINS QUE SERVEM NO DITO BERGANTIM, 15 MÃOS DE ARROZ A CADA UM.

Datas: 1525-04-07 - 1525-04-07

Código de referência: PT/TT/CC/2/124/198

Cota atual: Corpo Cronológico, Parte II, mç. 124, n. ${ }^{\circ} 198$

*CARTA DOS OFICIAIS DA CASA DA MINA PARA OS OFICIAIS DA ILHA DE S. TOMÉ EM QUE LHE DÃO CONTA DOS APARELHOS E COISAS QUE LHES REMETEM COM A CARAVELA NOVA, PARA O CONTRATO DA DITA ILHA PELO CAPITÃO JORGE MARTINS.

Datas: 1525-10-29 - 1525-10-29

Código de referência: PT/TT/CC/2/129/134

Cota atual: Corpo Cronológico, Parte II, mç. 129, n. ${ }^{\circ} 134$

*CONHECIMENTO EM QUE SE DECLARA QUE O FEITOR DA CIDADE DE S. JORGE DA MINA, PAIO RODRIGUES, RECEBEU 106 PEÇAS DE ESCRAVOS E BEM ASSIM O MANTIMENTO PARA OS DITOS ESCRAVOS NESTE DECLARADO, DO FEITOR MANUEL VAZ, DA ILHA DE SÃO TOMÉ. 


\section{REFERENCIAS}

ALBERTO VIEIRA. Disponível em: <http://www.avieira.net>. Acesso em:10 ago. 2016.

AGÊNCIA GERAL DO UlTRAMAR (Portugal). São Tomé e Príncipe: pequena monografia. Lisboa: Agência Geral do Ultramar, 1969. 143 p.

ALBUQUERQUE, Luís de; MAGAlHÃES, Ana Maria; ALÇADA, Isabel. Os descobrimentos portugueses: viagens e aventuras. $5^{\mathrm{a}}$ ed. Lisboa: Caminho, 1991. 218 p.

CALDEIRA, Arlindo Manuel. Viagens de um piloto português do século XVI à costa de África e a São Tomé. $1^{a}$ ed. Lisboa: Gráfica Maiadouro, S.A., 2000. 149 p.

CARREIRA, António. Estudos de economia cabo-verdiana. Lisboa: Imprensa Nacional-Casa da Moeda, 1981.

BOXER, Charles Ralph. The portuguese seaborne empire, 1415-1825. Michigan: Penguin, 1973. $436 \mathrm{p}$.

Porto: Afrontamento, 1988. 128 p.

Relações raciais no império colonial português: 1415-1825.

O império marítimo português, 1415-1485. Tradução de Anna Olga de Barros Barreto. São Paulo: Companhia das Letras, 2002. 442 p.

CARVALHO, Joaquim Barradas de. Esmeraldo de situ orbis de Duarte Pacheco Pereira. Lisboa: Fundação Calouste Gulbenkian, 1991. 868 p.

COSTA, José Domingos. João Menino - comerciante ou escravo? In: COLÓQUIO INTERNACIONAL SÃO TOMÉ E PRÍNCIPE NUMA PERSPECTIVA INTERDISCIPLINAR, DIACRÓNICA E SINCRÓNICA, 2012, Lisboa. Actas do Colóquio Internacional São Tomé e Príncipe numa perspectiva interdisciplinar, diacrónica e sincrónica. Lisboa: Instituto Universitário de Lisboa, Centro de Estudos Africanos, Instituto de Investigação Científica Tropical, 2012. p. 13-26.

FAUSTO, Boris. História do Brasil. $2^{a}$ ed. São Paulo: Editora da Universidade de São Paulo, 1995. 653 p.

FERLINI, Vera Lucia Amaral. Uma fábrica colonial: trabalho e técnica nos engenhos brasileiros. In: História e tecnologia do açúcar. Coleção Memória 30. Funchal: Centro de Estudos de História do Atlântico, 2000. p. 183-206.

FERNANDES, Hamilton. Açúcar e Álcool, ontem e hoje. Coleção Canavieira, n. 4. Rio de Janeiro, Instituto do Açúcar e do Álcool, 1971. 165 p.

FRUTUOSO, Gaspar. Saudades da terra: livro II. Ponta Delgada: Instituto Cultural de Ponta Delgada, 1998. 186 p.

FURTADO, Celso. Formação Econômica do Brasil. 32 ed. São Paulo: Companhia Editora Nacional, 2005. 238 p.

GALLOWAY, J. H. The sugar cane industry: an historical geography from its origins to 1914. New York: Cambridge University Press, 1989. 266 p.

GARFIELD, Robert. A history of São Tomé Island, 1470-1655: the key to Guinea. São Francisco: Mellen Research University Press, 1992. 327 p. 
GODINHO, Vitorino Magalhães. A expansão quatrocentista portuguesa: problemas das origens e da linha da evolução. Lisboa: Empresa Contemporânea de Edições, 1942. $150 \mathrm{p}$.

Portugal, as frotas do açúcar e as frotas de ouro (1670 - 1770). Revista de História, São Paulo, v.7, n. 15, p. 69-88, 1953.

Editorial Presença, 1963. v. 4.

Os descobrimentos e a economia mundial. Lisboa:

Os descobrimentos e a economia mundial. Lisboa:

Editora Arcádia, 1965. v. 2.

GOUVEIA, David Ferreira de. O açúcar da Madeira: a manufactura açucareira madeirense (1420-1550). Atlântico, Funchal, n. 4, p. 260-272, 1985.

HOLANDA, Sergio Buarque de (Org.). A época colonial: administração, economia, sociedade. Rio de Janeiro: Bertrand Brasil, 2003. (História Geral da Civilização Brasileira; t. 1; v. 2). 576 p.

INSTITUTO NACIONAL DE ESTATÍSTICA. Características e condições de vida das famílias e da habitação, RGPH-2012. São Tomé: INE, 2012. 163 p.

LAINS E SILVA, Hélder. São Tomé e Príncipe e a cultura do café. Lisboa: Junta de Investigações do Ultramar, 1958. 499 p.

LOPES, Edmundo Correia. A escravatura: subsídios para a sua história. Lisboa: Editorial Atica, 1944. 208 p.

LOPES, Duarte; PIGAFETTA, Filippo. Relação do reino de Congo e das terras circunvizinhas. Tradução de Rosa Capeans. Lisboa: Agência Geral do Ultramar, 1951.

LOUREIRO, Rui. Navegação de Lisboa à Ilha de São Tomé: escrita por um piloto português. Lisboa: Grupo de trabalho de ministérios da educação para comemorações dos descobrimentos portugueses, 1989. $41 \mathrm{p}$.

MAGALHÃES, Joaquim Romero. O açúcar nas ilhas portuguesas do Atlântico séculos XV e XVI. Varia Historia, Belo Horizonte, v. 25, n. 41, p. 151-175, 2009.

MARQUES, Vera Regina Beltrão. Boticários: a preparação de um ofício mecânico em domínios portugueses no setecentos. In: FÓRUM SUL DE COORDENADORES DE PÓSGRADUAÇÃO EM EDUCAÇÃO. II Seminário de Pesquisa em Educação da Região Sul, 1999, Curitiba. Disponível em: <http://www.portalanpedsul.com.br/admin/uploads/1999/Historia_Da_Educacao/Trabalho/05_3 7_31_BOTICARIOS_A_PREPARACAO_DE_UM_OFICIO_MECANICO_EM_DOMINIOS _PORTUGUESES_NO_SETECENTOS.pdf>. Acesso em: 11 jan. 2017. p. 3.

NUNES, Naidea Nunes. O açúcar de cana na ilha da Madeira: do Mediterrâneo ao Atlântico - Terminologia e tecnologia históricas e actuais da cultura açucareira. 2002. 778 f. Tese (Doutorado em Linguística Românica) - Faculdade de Artes e Humanidades, Universidade da Madeira, Funchal, 2002.

OGOT, Bethwell Allan (Ed.). História geral da África, V: África do século XVI ao XVIII. Brasília: UNESCO, 2010. 1208 p. 
PEREIRA, Fernando Jasmins. Estudos sobre história da Madeira. Funchal: C.E.H.A., 1991.

SCHWARTZ, Stuart. Segredos internos: engenhos e escravos na sociedade colonial. São Paulo: Companhia das Letras, 2005. 474 p.

SILVA, Alberto da Costa. A manilha e o libambo: a África e a escravidão de 1500 a 1700. Rio de Janeiro: Nova Fronteira, 2002. 1088 p.

SILVA, Teresa Madeira da. A cidade de São Tomé no Quadro das Cidades Insulares Atlânticas de Origem Portuguesa. In: COLÓQUIO INTERNACIONAL SÃO TOMÉ E PRÍNCIPE NUMA PERSPECTIVA INTERDISCIPLINAR, DIACRÓNICA E SINCRÓNICA, 2012, Lisboa. Actas do Colóquio Internacional São Tomé e Príncipe numa perspectiva interdisciplinar, diacrónica e sincrónica. Lisboa: Instituto Universitário de Lisboa, Centro de Estudos Africanos, Instituto de Investigação Científica Tropical, 2012. p. 50.

TENREIRO, Francisco. A Ilha de São Tomé. Lisboa: Junta de Investigações do Ultramar, 1961. 279 p.

THOMAZ, Luís Filipe Ferreira Reis. De Ceuta a Timor. Linda-a-velha: Difel, 1994. $778 \mathrm{p}$.

VIEIRA, Alberto. Portugal y las islas del Atlántico. Madrid: Editorial MAPFRE, 1992. $316 \mathrm{p}$.

O Açúcar na Madeira: produção e comércio nos séculos XV a XVII. In: Producción y comercio del azúcar de caña en época pré-industrial. Actas del Tercer Seminario Internacional. Granada: Diputación Provincial de Granada, 1993. p. 34-67.

As Ilhas e a expansão da cultura e tecnologia da cana-de-açúcar no Atlântico nos séculos XV a XIX. Revista Labor \& Engenho. Campinas, v. 1, n. 1, p 120, 2007. 